\title{
ANÁLISE DE UMA UNIDADE DE CONSERVAÇÃO AMEAÇADA - A ESTAÇÃO ECOLÓGICA DE IBICATU, PIRACICABA (SP) - COMO SUBSÍDIO PARA ELABORAÇÃO DE SEU PLANO DE MANEJO
}

\author{
JOSÉ FLÁVIO MACHADO CÉSAR LEÃO \\ Engenheiro Agrônomo
}

Orientador: Prof. Dr. ÁLVARO FERNANDO DE ALMEIDA

Dissertação apresentada à Escola Superior de Agricultura "Luiz de Queiroz", da Universidade de São Paulo, para obtenção do titulo de Mestre em Ciências Florestais 
Ficha catalográfica preparada pela seção de Livros da Divisāo de Biblioteca e Documentaçāo - PCLQ/USP

1. Área de conservação - Análise 2. Estação Ecológica de Ibicatu - Manejo I. Escola superior de Agricultura Luiz de Queiroz, Piracicaba
} 
ANÁLISE DE UMA UNIDADE DE CONSERVAÇÃO AMEAÇADA - A ESTAÇÃO ECOLÓGICA DE IBICATU, PIRACICABA (SP) - COMO SUBSÍDIO PARA ELABORAÇÃO DE SEU PLANO DE MANEJO

JOSÉ FLÁVIO MACHADO CÉSAR LEÃO

Aprovada: $17 / 11 / 1994$

Comissão Julgadora:

Dr. Álvaro Fernando de Almeida

Dr. Fábio Poggiani

Dr. Waldir Mantovani

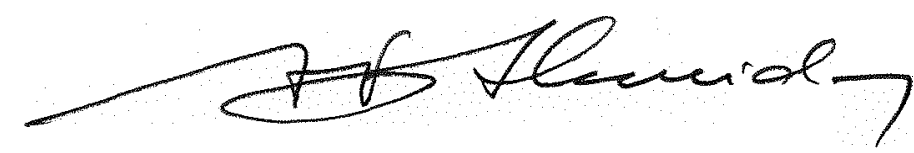

Prof. Dr. ÁLVARO FERNANDO DE ALMEIDA Orientador 
Dedico este trabalho

Aos meus pais, Leo e Mariinha, pelas lições de vida A Regina, pelo apoio e incentivo em todos estes anos de convívio Aos meus filhos, Maria e Marcelo pelo carinho e compreensão, indispensáveis na realização desta tarefa 


\section{AGRADECIMENTOS:}

Ao amigo e orientador Prof. Dr. Álvaro Fernando de Almeida, que soube motivar e despertar o interesse pelo estudo e a pesquisa

Ao Prof. Dr. Humberto de Campos, pela confiança depositada

Ao Prof. Dr. Irineu Umberto Packer, pelo apoio constante ao meu trabalho

Ao Prof. Dr. Antonio Natal Gonçalves, pelo companheirismo de muitos anos

Ao Prof. Dr. Fábio Poggiani pelo exemplo de dedicaçăo à vida acadêmica

Ao Prof. Dr. Virgilio M. Viana, pelo idealismo transmitido em nossa convivência

Ao Prof. Dr. Hilton Thadeu Z. do Couto, pela compreensão de nossas limitações

Ao Prof. Dr. Paulo Yoshio Kageyama, pela demonstraçăo de aplicaçăo ao estudo e à pesquisa

Ao Prof. Dr. Carlos Sodero Martins, que soube nos mostrar que o humanismo pode caminhar ao lado da ciência

A todos os colegas da pós-graduação que sempre me incentivaram com sua alegria e amizade 
Aos funcionários da Escola Superior de Agricultura "Luiz de Queiroz" pela sua costumeira cordialidade e solicitude

Ao amigo Eduardo Curi Mello Ayres, por ter me ajudado a vencer muitos obstáculos

A Beatriz Helena Giongo e Marialice Metzker Poggiani pela importante cooperação neste trabalho

À FAPESP - Fundação de Amparo à Pesquisa do Estado de Săo Paulo, pelo apoio e incentivo à realizaçăo desta pesquisa

Aos amigos que trabalham no Instituto Florestal da Secretaria do Meio Ambiente do Estado de São Paulo, os quais, de alguma forma, me auxiliaram nesta tarefa 


\section{ÍNDICE}

Página

LISTA DE FIGURAS

vii

LISTA DE TABELAS ix

RESUMO $\quad$ xi

SUMMARY xiii

$\begin{array}{ll}\text { 1. INTRODUÇÃO } & 01\end{array}$

2. REVISÃO BIBLIOGRÁFICA 04

2.1. A devastação florestal 04

2.2. Os fragmentos florestais 08

2.3. O mecanismo da sucessão vegetal 12

2.4. Aspectos da preservação da fauna 15

2.5. Unidades de conservação 16

2.5.1. Evolução histórica 16

2.5.2. Conceituação e objetivos das unidades de conservação $\quad 25$

2.5.3. Classificação das unidades de conservação $\quad 28$

2. 5.4. Estação ecológica $\quad 32$

2.6. Planejamento ambiental das áreas silvestres $\quad 37$

$\begin{array}{ll}\text { 2.7. Estudos de casos } & 42\end{array}$

2.8. Aspectos da Educação Ambiental 45

3. MATERIAL E MÉTODOS 50

3.1. Localização geográfica da área 50

$\begin{array}{ll}\text { 3.2. Aspectos históricos } & 61\end{array}$

3.2.1. Antecedentes regionais 61

3.2.2. Histórico da Estação Ecológica de lbicatu 63 
3.3. Aspectos biofísicos 66

3.3.1. Geologia e geomorfologia 66

3.3.2. Solos 69

3.3.3. Clima $\quad 74$

3.3.4. Hidrologia $\quad 87$

3.3.5. Vegetação $\quad 92$

3.3.6. Fauna 105

3.3.7. Paisagem local: visuais cênicas 117

$\begin{array}{ll}\text { 3.3.8. Mobiliário existente } & 120\end{array}$

3.4. Estudos de deriva ambiental na Unidade de Conservação $\quad 122$

3.4.1. Aspectos gerais $\quad 122$

3.4.2. Análise da situação local $\quad 124$

3.5. Contexto sócioeconómico e cultural 133

3.5.1. Características da população regional 133

3.5.2. Evolução urbana no município de Piracicaba 138

3.5.3. Aspectos da economia local 139

3.5.4. Aspectos culturais 142

4. DISCUSSÃO E PROGNÓSTICOS 146

4.1. Considerações gerais 146

4.2. Proposta para organização espacial $\quad 150$

4.3. Considerações sobre os programas de manejo 153

4.4. Programa de desenvolvimento físico 153

4.4.1. Subprograma de implantação de infra-estrutura 153

4.4.2. Subprograma de instalação de obras $\quad 154$

4.5. Programa de administração e manutenção 157

4.6. Programa de educação ambiental 158

$\begin{array}{ll}\text { 4.7. Programa de pesquisa } & 159\end{array}$

4.8. Programa de mobilização comunitária 160

5. CONCLUSÕES 161

$\begin{array}{ll}\text { REFERENCIAS BIBLIOGRÁFICAS } & 165\end{array}$ 


\section{LISTA DE FIGURAS}

FIGURA

PÁGINA

01

Localização da Estação Ecológica de lbicatu no contexto nacional e estadual

51

02

Estação Ecológica de Ibicatu: Principais vias de acesso

52

03

Localização da Estação Ecológica de lbicatu no contexto regional

Localização da Estação Ecologica de lbicatu no contexto municipal

56

05

Estação Ecológica de lbicatu: localização

57

06

Estação Ecológica de Ibicatu: Planta topográfica

60

07

Mapa pedológico do entorno da Estação Ecológica de lbicatu

08

Precipitações pluviométricas médias no municipio de Piracicaba: $1917 / 1980$

Distribuição das temperaturas máximas e mínimas para a região de Piracicaba: $1981-90$

80

11 Distribuição da Radiação Solar para a região de Piracicaba: 1981-1990

Distribuição da Insolação para a região de

Piracicaba: 1981 - 1990

Estaçăo Ecológica de lbicatu; no contexto da Hidrovia Tietê/Paraná 


\section{LISTA DE FIGURAS (Continuação)}

FIGURA

Página

16

Ocorrencia de Euterpe Edulis (mutualista-chave) no interior da Estação Ecológica de lbicatu

Residência existente na Estação Ecológica de Ibicatu atualmente fechada

18 Aproximação aerea, mostrando o cultivo de cana-de-açúcar em area vizinha à Estação Ecológica de Ibicatu (1)

Aproximação aérea, mostrando o cultivo de cana-de-açúcar em área vizinha à Estação Ecológica de Ibicatu (2)

Plantio de cana-de-açúcar no entorno da Estação Ecológica de lbicatu

Área degradada no interior da floresta em decorrência do aumento excessivo de água retida no local

Clareira observada no interior da floresta da Estação

Ecológica de lbicatu

Processos erosivos ocorrentes em área vizinha da

Estação Ecológica de Ibicatu (1)

24 Processos erosivos ocorrentes em área vizinha da

Estação Ecológica de lbicatu (2)

Áreas degradadas existentes no entorno da

Estação Ecologica de Ibicatu

População urbana e rural: municipio de Piracicaba

Estação Ecológica de Ibicatu: Proposta de área a ser adquirida. Escala: 1:10.000

Estação Ecológica de lbicatu: sugestão para criação de "zona tampăo", coincidente com os limites da bacia hidrográfica. Escala: 1:10.000 


\section{LISTA DE TABELAS}

TABELA

PÁGINA

01

Situação Florestal do Estado de São Paulo

07

02

Áreas protegidas do Estado de São Paulo

03

Condições climáticas médias do municipio de

Piracicaba: $1917 / 1970$

76

04

Resultados numéricos do Balanço Hídrico de Piracicaba

79

05

Velocidade média do Vento $(\mathrm{m} / \mathrm{s})$

Piracicaba - SP: 1943 - 1970

83

06

Direção dos ventos - Piracicaba - SP: 1943 - 1970

Número de ocorrencias em cada direção às 7 horas

07

Direção dos ventos - Piracicaba - SP: 1943 - 1970

Número de ocorrências em cada direção às 14 horas

85

08

Direção dos ventos - Piracicaba - SP: 1943 - 1970

Número de ocorrências em cada direção às 21 horas

86

09

Relação das espécies vegetais amostradas

Estação Ecológica de lbicatu - Piracicaba - SP

97

10

Listagem preliminar da mastofauna na

Estação Ecológica de lbicatu - Piracicaba - SP

107

11 Listagem preliminar da avifauna na

Estação Ecológica de Ibicatu - Piracicaba - SP

12

Listagem preliminar da herpetofauna na

Estação Ecologica de lbicatu - Piracicaba - SP

População -Região de Governo de Piracicaba - 1992 
LISTA DE TABELAS (Continuação)

TABELA

PÁGINA.

15 Rede de ensino-Pré-escola, Primeiro e Segundo Grau

Município de Piracicaba - 1991

16

Rede de Ensino Superior - Municipio de Piracicaba-1992

144 


\section{RESUMO}

O presente trabalho objetiva fornecer subsidios para a elaboração de um Plano de Manejo para a Estação Ecológica de lbicatu, Unidade de Conservação administrada pelo Instituto Florestal, da Secretaria do Meio Ambiente do Estado de São Paulo. Este fragmento florestal é um patrimônio natural de valor inestimavel, por ser uma amostra da biota caracteristica da mata mesófila semidecidual do interior paulista, e por abrigar, no seu interior, milenares jequitibás (Cariniana legalis) de porte majestoso e beleza impar.

A elaboração do seu Plano de Manejo é um instrumento indispensável para a efetiva conservação da área e para a conseqüente manutenção de sua biodiversidade, uma vez que ações antropogênicas efetuadas no seu entorno, como a exploração agropecuária, podem ameaçar a sua estabilidade. Além disso, em face do desenvolvimento da cidade de Piracicaba, que dista apenas 32 quilometros da "Mata de lbicatu", e com a conclusão das obras de pavimentação dos acessos ao local, acredita-se que, no futuro próximo, ela receberá uma maior pressão de uso por parte da comunidade, necessitando, portanto, que se estabeleça a normatização desta utilização através do seu Plano de Manejo.

Neste contexto, foram efetuadas pesquisas na literatura pertinente, levantamentos de campo, e análises especificas da situação encontrada, objetivando fornecer elementos para maior conhecimento da area em questão. Desta forma, sugere-se que o Plano de Manejo para a Estação Ecológica de lbicatu desenvolva programas específicos, que compatibilizem a adequada conservação ambiental, com alternativas de uso público, sempre de acordo com a legislação vigente, que condiciona o uso da area para a pesquisa cientifica e para a Educação Ambienta!. 
A proposta básica de organização espacial para aquela Unidade de Conservação, que pode servir como referência para o futuro Plano de Manejo, prevê um zoneamento para o local, em função da sua vocação específica, e das necessidades e possibilidades de utilização. Assim, foram estabelecidas cinco zonas especificas: Primitiva, de Uso Extensivo, de Uso Intensivo, de Recuperação e de Uso Especial.

Propõe-se também a criação de cinco programas de manejo para a Estação Ecológica de lbicatu os de Desenvolvimento Físico, Administração e Manejo, Educação Ambiental, Pesquisa e Mobilização Comunitária, que devem funcionar interligados para assegurar a efetiva proteção do local.

Outra questão levantada e a necessidade de ampliação da area da Estação Ecologica de Ibicatu, cuja estabilidade pode estar ameaçada, em função das suas pequenas dimensóes, da sua forma espacial inadequada e das condições de isolamento geográfico em que se encontra. Portanto, recomenda-se também a criação de "zonas-tampăo" no seu entorno, onde o uso do solo deverá ser parciaimente restrito.

$E^{\prime}$ conveniente ainda a criação de corredores vegetados, interligando os diversos fragmentos florestais existentes na região, de forma a propiciar a circulação e o escape dos animais entre eles, e assegurando o fluxo de material genetico, fundamental para a sobrevivencia das comunidades ali existentes.

Finalmente, preconiza-se a mobilização da sociedade como um todo para a defesa do importante património representado por esta Unidade de Conservação. 


\title{
ANALYSIS OF AN ENDAGERED CONSERVATION UNIT - THE IBICATU ECOLOGICAL STATION, PIRACICABA, S.P. - AS A SUBSIDY FOR THE ELABORATION OF A HANDLIG PLAN
}

\author{
Author: José Flavio Machado César Leão \\ Adviser: Prof. Dr. Álvaro Fernando de Almeida
}

\section{SUMMARY}

The aim of this work is to provide subsidies for the elaboration of a Handing Plan for the Ibicatu Ecological Station, a Conservation Unit managed by the Instituto Florestal, São Paulo State Environment Bureau. This forest fragment is as priceless natural patrimony for being a sample of the biota characteristic of the semideciduous mesophyllous forest in São Paulo State, and for sheltering millennial majestic "Jequitibás" (Cariniana legalis), with its remarkable beauty.

The elaboration of its Handling Plan is an essential instrument for an effective conservation of the area and therefore for maintaining its biodiversity once anthropogenic actions accomplished in its vicinities, such as the agriculture exploitation, may endanger its stability. In addition, in view of the development of Piracicaba - only 32 kilometers away from the "lbicatu Forest"- and the conclusion of paving works of the ways leading to that area, it is believed to undergo a higher use pressure by the community in a close future, thus requiring the standardization of such use through its Handling Plan.

Literature research, field surveys, and specific analysis of the current situation were accomplished in an effort to provide elements for a broader knowledge of the area. Thus, the Handling Plan for the Ibicatu Elogical Station is suggested to develop specific programs which should combine the suitable environmental conservation and alternative public use, always in accordance with the current legislation, which implies that the area shall be used for scientifical research and for Environmental Education.

The basic proposal for a spatial organization for that Conservation Unit, which may work as a reference for the future Handiing Plan, forecasts a site zoning acoording to its specific fitness and the needs and possibilites of use. Thus, five 
specific zones were established: Primitive, Extensive Use, Intensive Use, Recovery, and Special Use.

Another issue is the need for an enlargement of the Ibicatu Ecological Station area, since its stability may be endangered because of small dimensions, unsuitable spatial form, and geographical isolation conditions. Therefore, the creation of zones in the vicinities is also recommended, where the use of soil shall be partialiy restrict.

Also convenient is the creation of vegetated corridors, connecting several forest fragments in that area, so as to provide the circulation and escape of animals among them, and assuring the flow of genetical material, fundamental for the survival of the communities therein.

Finnaly, the mobilization of the society as a whole for the defense of the important patrimony represented by this Conservation Unit is advised. 
"Se as árvores não possuem voz para clamar piedade contra a devastação das florestas, ai estão os filhos espirituais da "Luiz de Queiroz" que hão de estender o seu manto protetor sobre os gigantes verdes que fecundaram a terra brasileira."

(Jornalista Losso Neto, 1958, no Jornal de Piracicaba, falando sobre a floresta de Ibicatu) 


\section{INTRODUÇÃO}

A devastação dos ecossistemas naturais tem sido uma constante nos processos de ocupação territorial, especialmente em decorrência do avanço das fronteiras agrícolas que se instalaram em nosso pais desde a sua colonização. Esta constatação torna-se ainda mais clara ao observarmos a crítica situação do Estado de São Paulo, onde existe apenas $5,7 \%$ da vegetação original (MILANO, 1990), caracterizando, de forma inquestionável, a degradação ambiental e a velocidade acelerada da destruição da natureza.

Em função deste quadro, a Estação Ecológica de Ibicatu, Unidade de Conservação administrada pelo Instituto Florestal, da Secretaria do Meio Ambiente do Estado de São Paulo, localizada na zona oeste do município de Piracicaba, distando cerca de 32 quilómetros do núcleo urbano, com $76,4 \mathrm{Ha}$. de área, tem sua importância relevante. Ela representa um património natural de valor inestimavel, por reunir uma paisagem de beleza cenica impar, especialmente representada pelo porte majestoso dos jequitibás - Cariniana legalis - que lá se encontram e por se tratar de um fragmento florestal que abriga parte da biota característica da mata mesófila semi-decidual do interior do Estado.

A importância desta Estaçăo aumenta ainda mais, à medida em que o desenvolvimento urbano avança na sua direção. Atualmente, a construção e modernização da malha viária regional, especialmente definida pela pavimentação das rodovias Pl-040 (Piracicaba-Anhumas) e SP-147 (Piracicaba-Anhembi) que serão articuladas no futuro próximo com o sistema hidroviário Tietê-Paraná, vão exercer uma forte pressão de utilização e ocupação humana no frágil ecossistema definido pela Unidade de Conservação e seu entorno. 
Dessa forma, em virtude das maiores facilidades de acesso a area e do crescimento das areas urbanas das cidades da região, espera-se que nos proximos anos, a Estação Ecologica de lbicatu receba uma solicitação de "aproveitamento" e uso por parte da população, cuja resposta deverá ser dada pela sua administração, atraves da elaboração e implementação do seu Plano de Manojo, instrumento indispensável para cuidar da sua efetiva conservação e da conseqüente manutenção da biodiversidade que ela encerra.

Observa-se que a interferência humana equivocada. através da atividade agropecuaria desenvolvida no entorno da area em questão, onde nem sempre são levadas em conta as práticas conservacionistas, está colocando em risco a Unidade de Conservação e a sobrevivência das espécies ali existentes. Segundo MACKINNON et alli (1986), como principio geral, a agricultura intensiva $e$ as areas protegidas não são boas vizinhas. Por isso, é necessária a criação entre as duas de "zonas-tampão", com o estabelecimento de um uso intermediário para estas terras. Isto não ocorre atualmente no entorno da Estação Ecologica de lbicatu, que está vulnerável, não dispondo até 0 momento, nem de um sistema de vigilancia, nem de cercas ao longo do seu perimetro, ocorrendo muitas vezes a invasão da fioresta pelo gado que pastoreia nas suas imediações.

O intenso uso agricola, principalmente para o plantio de cana-de-açúcar, realizado em terrenos próximos à Estaçäo, vem provocando a formação de processos erosivos do solo. Tal situação compromete em especial os cursos d'agua e as suas nascentes. Isto vem causando sérios danos ambientais, representados pelo assoreamento de areas localizadas no interior da floresta, provocando a morte da vegetação arbórea, através do aumento excessivo e descontrolado do nivel de água do solo. Verifica-se, em alguns pontos da mata, grandes clareiras, onde predominam espécies arbustivas e herbáceas, comprometendo a estabilidade da Estação Ecológica de Ibicatu. Outra ameaça constante e o fogo, cujo perigo aumenta à medida em que o cultivo da cana se aproxima da Unidade de Conservação, com as queimadas periódicas efetuadas por ocasião da sua colheita. 
Dai decorre a necessidade da realização de estudos multidisciplinares, propiciando o maior conhecimento possivel sobre a Estaçăo Ecológica de lbicatu, para subsidiar assim a elaboração do seu Plano de Manejo. Ele definirá os diversos programas a serem desenvolvidos no local, assegurando seu uso adequado $e$, conservando, ao mesmo tempo, 0 ambiente primitive.

Este trabalho objetiva, portanto, fornecer subsídios ao desenvolvimento de ações efetivas para minimizar o efeito das perturbaçóes de origem antropogenica sobre o fragmento florestal, assegurando efetivamente sua condição de museu vivo da paisagem natural. Âo mesmo tempo, procura desenvolver instrumentos alternativos de gestão no âmbito da administração e manutenção da Estação Ecológica.

Pretende, também contribuir, fornecendo subsidios para que - Plano de Manejo compatibilize a proteção ambiental com um programa adequado de utilização do local por parte da comunidade. Este programa de uso publico, obedecendo a legislaçăo em vigor, relativa ao manejo das Estações Ecológicas, deve contemplar aspectos da Educação Ambiental e de Interpretação da Natureza. Tais programas devem ser dirigidos não somente a estudantes, mas tambem a todos os moradores da regiấ, para que estejam plenamente conscientes da importancia da Mata de lbicatu e da necessidade de conservar este riquissimo patrimonio natural para as geraçōes futuras. 


\section{REVISÃO BIBLIOGRÁFICA}

\subsection{A devastação florestal}

O grande e rápido desenvolvimento da civilização moderna temi ocasionado profundos desequilibrios ambientais, destruindo os recursos naturais renováveis, ameaçando a vida selvagem e comprometendo o futuro do próprio homem. De acordo com a Agência de Cooperação Técnica do Japão (JICA), citada por OGAWA et alli (1990), as florestas na superficie do globo estão sendo reduzidas em um ritmo alarmante Em 1960, ocupavam $1 / 4$ da superficie terrestre em 1980 , estavam reduzidas a $1 / 5$, no ano 2000 estima-se sua redução para $1 / 6$ e no ano 2020 ocuparão apenas $1 / 7$.

Para estes autores, a quase totalidade desta redução ocorre nas áreas de florestas tropicais que são os ecossistemas mais ricos do planeta, estimando-se que contenham por $2 / 3$ das espécies existentes, muitas das quais ainda desconhecidas.

A devastação intensiva das áreas florestadas na América do Sul começou mais tardiamente dos que nos outros continentes, mas nem por isso tem sido menos violenta. $E$ ' conseqüencia direta das formas de utilização destas áreas para a instalação de projetos agricolas, pastorís e industriais e das atividades de extração de madeiras de forma inadequada.

Neste contexto, o processo de ocupação do solo brasileiro foi marcado, no decorrer dos séculos, pela destruição sistemática das florestas naturais, que cobriam originaimente grande parte do território nacional. O Estado de São Paulo, por exempio, onde o desenvolvimento economico foi mais intenso. 
tornou-se um dos mais afetados: de acordo com SERRA FILHO et al (1974) e VICTOR (1975), O Estado apresentava, no inicio do seculo XIX, uma cobertura vegetal correspondente a $81,8 \%$ de sua area e em $1972 / 3$, a fioresta primitiva e as areas perturbadas, conhecidas como capoeiras, perfaziam um total de $13,33 \%$ do seu território.

AB'SÁBER (1977) afirma que "as coberturas vegetais antigas do Estado de São Paulo, constituidas sobretudo por matas e cerrados, foram eliminadas: substituídas que foram pela expansão dos campos de cultura, pastagens, metropoles e cidades, parques industriais, grandes represas e numerosos tipos de loteamentos especulativos. Em termos de degradação do patrimônio ambiental, somam-se as consequiências dos dois grupos de acionadores de desenvolvimento. Existe, certamente uma poluição associada ao quadro global de desenvolvimento, ao par de uma outra, vinculada ao quadro geral de subdesenvolvimento. Ao desenvolvimento se deve a poluição dos rios, a poluição do ar, a poluição química, a poluição visual, a poluição sonora. Ao subdesenvolvimento se deve a poluição dos corregos, a poluição dos bairros dormitorios e das favelas, a poluição dos lençois superficiais, a poluiçáo sanitaria Compiexos processos de polarização das atividades, desdobramentos e poligonações na trama viária, ações persistentes dos funis e nódulos de estrangulamento de tráfego, contribuiram para diversificar e identificar as formas de ocupação do solo, valorizar as terras e diminuir as possibilidades de se reservar áreas para uso comunitário, a serviço da sociedade como um todo".

O desmatamento continuou com o tempo. RODRIGUES (1989) cita um levantamento do Instituto Florestal onde, ha treze anos, apenas cerca de $5 \%$ de toda a área do Estado ainda se apresentava florestada com matas nativas. Desta cobertura remanescente, somente $2 \%$ correspondem às formações residuais do interior do Estado e o restante, à formação atlántica de encosta. Nas formações interioranas, estão incluidos os remanescentes de floresta de planalto e cerrado, na maioria protegidos sob a forma de reservas e, também a vegetação natural existente ao longo dos cursos d'água 
Através de um levantamento completo da vegetação, efetuado em 1989, com o apoio do satelite LANDSAT -5, verificou-se que apenas $13,7 \%$ da superficie do Estado de São Paulo era coberta com vegetação nativa. (INSTITUTO DE BOTÂNICAVECRETARIA DO MEIO AMBIENTE, 1993). DE acordo com esta mesma fonte, dados mais recentes, apresentados no Atlas da evolução dos Remanescentes Florestais e Ecossistemas associados do Domínio da Mata Atlantica (FUNDAÇÃO SOS MATA ATLÂNTICAINPE, 1992) deram conta de um percentual ainda menor, ou seja, de apenas $7,16 \%$ de cobertura florestal natural. Os dados do estudo revelaram que aparentemente, a causa dos maiores desmatamentos recentes do Estado de Sáo Paulo e a expansão agropecuária, representada principalmente pelas culturas de cana-de-açúcar, laranja, reflorestamentos homogêneos e pastagens. Portanto, um dos principais fatores de pressão sobre os poucos remanescentes florestais existentes é esta intensa atividade económica.

De acordo com o levantamento efetuado pelo FUNDO DE DESENVOLVIMENTO FLORESTAL (1993a) a situação florestal do Estado de Säo Paulo vem evoluindo da seguinte forma nas últimas tres decadas, conforme mostra a Tabela 1 : 
Tabela 1 - SITUAÇÃO FLORESTAL DO ESTADO DE SÃO PAULO

Area de vegetação nativa e participação na área estadual

\begin{tabular}{|l|rr|rr|rr|}
\hline \multicolumn{1}{|c|}{ Tipos } & 1973 & 1989 & 1991 & \\
& $(1000 \mathrm{ha})$ & $\%$ & $(1000 \mathrm{ha})$ & $\%$ & $(1000 \mathrm{ha})$ & $\%$ \\
\hline $\begin{array}{l}\text { VEGETAÇÃO } \\
\text { NATURAL }\end{array}$ & $(1)^{*}$ & $(2)^{\star}$ & $(3)^{\star}$ & \\
\hline Mata & 2.069 .920 & 8,33 & 1.846 .966 & 7,58 & 1.579 .918 & 6,37 \\
\hline Capoeira & 1.241 .090 & 4,99 & 983.914 & 4,04 & & \\
\hline Cerradăo & 105.390 & 0,42 & 73.175 & 0,30 & 198.319 & 0,79 \\
\hline Cerrado & 784990 & 3,16 & 208.647 & 0,86 & 301.116 & 1,21 \\
\hline Campo cerrado & 148.990 & 0,60 & 1.883 & 0,01 & & - \\
\hline Campo & 43.870 & 0,18 & 1.933 & 0,01 & & - \\
\hline Total & 4.394 .250 & 17,68 & 3.116 .518 & 12,57 & 2.079 .353 & 8,37 \\
\hline
\end{tabular}

(1)* CHIARINI, J.V. \& DONZELLI, P.L. Levantamento por Fotointerpretaçăo das Classes de Capacidade das Terras do Estado de São Paulo. Campinas, Instituto Agronómico, 1973. Apud. Florestar Estatistico, São Paulo, (1): 10, $1993 a$.

$(2)^{\star}$ FUNCATE/DEPRN/FUNDAÇÃO FLORESTAL. Levantamento do Programa Olho Verde s.n.t. Apud Florestar Estatistico, Såo Paulo, (1): 10, 1993a.

(3) ${ }^{\star}$ IEA/CATI. s.n.t. Apud. Florestar Estatistico, São Paulo, (1): 10, 1993a 
CASTANHO FILHO \& FEIJO (1987) afirmam que a vegetaçao florestal remanescente no Estado de São Paulo resume-se a fragmentos mantidos na forma de reservas, estações e parques florestais do Estado ou em áreas de particulares, onde sua preservação foi consequiencia das dificuldades topográficas para trabalhá-las. Com o crescimento da especulação imobiliaria e o desconhecimento do tamanho ideal de uma reserva, para que as populações de animais e vegetais possam sobreviver, estes fragmentos apresentam riscos de diminuirem ou, ate mesmo de extinguirem-se.

\subsection{Os fragmentos florestais:}

VIANA (1990) define o fragmento florestal como qualquer area de vegetaçẫo natural continua, interrompida por barreiras antrópicas (estradas, culturas agricolas, etc.) ou naturais (lagos, outras formações vegetais, etc.) capazes de diminuir significativamente o fluxo de animais, polen elou sementes. Para este autor, quando ocorre a fragmentação da floresta, ocorrem mudanças imediatas e pronunciadas, iniciando-se pelas mudanças na luminosidade, temperatura, umidade e velocidade do vento. Estas mudanças são mais pronunciadas na borda e diminuem na direção do interior da floresta. Para as plantas, os efeitos de borda podem ser diretos (ex. climáticos) ou indiretos (ex: interaçốes com polinizadores, dispersores, cipós, etc.). Com o aumento da luminosidado na borda dos fragmentos, ocorro um aumento no crescimento de especies pioneiras, especialmente cipós (Lewis, citado por VIANA, 1990).

As açōes antropogênicas equivocadas ocasionaram a fragmentação das florestas e a extinção de muitas especies. Segundo a Organização das Nações Unidas para a Alimentação e a Agricultura (FAO), citada por KAGEYAMA (1987) dos fatores que contribuem para a extinção das especcies, o efeito de isolamento ou fragmentação do ecossistema seria o mais importante: das 77 especies de passaros e mamiferos extintos na recente história, 53 eram formas de distribuição insulares.

De acordo com a teoria da "biogeografia das ilhas", criandose uma reserva, isto e uma "ilha biologica", induzir-se-a a uma diminuicão da 
diversidade de espécies. O numero de espécies que uma reserva pode suportar at equilibrium dependera do seu tamanho, sua distancia de outras areas que funcionem como hábitats e da capacidade de dispersão que as espécies possuem (MAACKINNON et alii, 1986).

WILCOVE et alii, (1986) dizem que a fragmentação de hábitats tem dois componentes que causam a extinção, $O$ primeiro seria a redução da area total do hábitat, que afeta principalmente o tamanho das populaçóes e. assim, a taxa de extinção. $O$ segundo seria a redistribuição da area remanescente em fragmentos, o que afeta principaimente a dispersào e, assim, a taxa de imigração.

KAGEYAMA (1987) destaca também que, segundo Frankel \& Soulé, a extinção de uma especie ou população e a sua falha para manter-se por si através da reprodução, podendo ocorrer tanto quando o último individuo morre, ou quando os individuos remanescentes são incapazes de reproduzir progênies viáveis ou ferteis.

Para VIANA (1990), as consequencias mais importantes do processo de fragmentação das florestas tropicais, que antes eram continuas e foram perturbadas e isoladas entre si pela açăo antrópica são: a diminuição da diversidade biológica, o distúrbio do regime hidrológico das bacias hidrográficas, as mudanças climáticas, a degradação dos recursos naturais e a deterioração da q̨ualidade de vida das populações tradicionais.

COSTA (1992) afirma que quando uma area de floresta e isolada, a imporkancia das espécies arboreas é ainda mais reievante, pois a continuidade da integridade estrutural e bióógica da comunidade depende, em grande parte, das suas caracteristicas. Por outro lado, o impacto do isolamento, a curto e médio prazos, nas espécies arbóreas no fragmento é diffil de ser avaliado, devido às caracteristicas que conferem a esses organismos um papel preponderante no ecossistema, ou seja, organismos fixos, autotroficos e de grande longevidade, conforme Rankin-de-Merona \& Ackerly, citados por COSTA (1992). Mesmo quando nâo existe uma populaçăo reprodutiva de uma especie 
arborea, capaz de mantê-la presente na comunidade, o fato não é imediatamente evidente, devido a presenca de individuos daquela especie.

Uma espécie pode estar efetivamente extinta antes que o último individuo remanescente da população morra (LOVEJOY et alii, 1983). Os fragmentos florestais apresentam um processo continuo de constantes mudanças, onde nem sempre sua estabilidade esta assegurada: eles podem estar condenados ao desaparecimento muito antes que se perceba grandes alteraçóes no seu aspecto fisionómico.

Outro problema verificado paralelamente à fragmentação das fiurestas $e$ a destruiçáo das matas ciliares, que têm um importante papel como elemento de proteção dos recursos naturais, desempenhando funções hidrológicas e ccológicas. Segundo PORTO et al., (1976) as formações existentes ao longo dos cursos d'água apresentam caracteristicas abioticas proprias, com relação à fertilidade do solo, flutuação do lençol freatico e microclima. Devido a essas caracteristicas, são observados. nessas formações, processos naturais de seletividade ambiental, que determinam as especies ocupantes dessas àreas, e têm como elemento principal a freqüencia de alagamentos.

Segundo STEINBLUMS et al. (1984) e PLATTS et al. (1987), o ecossistema ripário executa sua função hidrológica atraves das seguintes formas principais:

- estabilizaçăo dessa area critica que sâo as ribanceiras do rio, pelo desenvoivimento e manutenção de um emaranhado radicular;

- como tampâo e fitro entre os terrenos mais altos e o ecossistemá aquático, participa do controle do ciclo de nutricntes na bacia hidrográfica, atraves de ação, tanto no escoamento superficial, quando na absorção de nutrientes do escoamento suh-superficial, pela vegetação ciliar; 
- pela diminuicão e filtragem do escoamento superficial impede ou dificulta o carreamento de sedimentos para o sistema aquatico, contribuindo, desta forma, para a manutenção da qualidade da água nas bacias hicrográricas;

- pela sua integraçấo com a superficie da águá, proporciona cobertura e alimentação para peixes e outros componentes da fauna aquática;

- pela mesma razão, intercepta e absorve a radiação solar, assim contribuindo para a estabilidade térmica dos pequenos cursos d'água.

Analisando a água de chuva que chega a uma bacia hidrográfica, verifica-se que ela contribui para o deflúvio (o volume de água que passa pela seçāo transversal de um canal, durante um determinado tempo), de diversas maneiras: através da precipitação direta na superficie da água, do escoamento superficial (hortoniano), ou então, a agua que infiltra no solo pode apresentar um escoamento sub-supericial, ou seja, escorrendo lateralmente em direção aos canais. Finalmente a água pode se aprofundar no solo em direção ao aquifero, para alimentar o defluvio no periodo das secas. Por isso, LIMA (1989) considera que as areas riparias cievem estar em boas condiçóes de proteção, com cobertura vegetal adequada, a fim de que o funcionamento hidrológico do sistema como um todo, ou seja, da bacia hidrográfica, permaneça harmónico.

Ainda do ponto de vista hidrológico, KAGEYAMA et alii (1986) afirmam que a mata ciliar funciona como filtro de escoamento superficial (runoof superficial), pelo fato de que ela desenvolve condições mais propicias à infiitração. Em florestas naturais, è rara a ocorrencia de runoff superficial. Desta forma, con a proteção da mata ciliar, a possibilidade de que possíveis contaminantes da qualidade da água (sedimentos, adubos, defensivos agricolas, etc.) atinjam o curso d'agua ficara na dependência de sua largura, estágio de desenvolvimento, composição floristica e sua efetiva participaçẫo na melhoria das condiçóes hidrologicas do solo 
Os fundamentos desta interação entre a mata ciliar e a proteçăo dos recursos hídricos derivam do conceito recente em hidrologia fiorestal referido como área variável de influência, segundo o qual a área da bacia hidrográfica que efetivamente contribui com runoff supericial para o hidrograma direto de uma chuva, e constituida principalmente pelos terrenos que margeiam os cursos d'água (isto é contrário, portanto, ao conceito hortoniano de geração de deflúvio), além de algumas outras situaçōes ao longo da bacia, tais como áreas encharcadas, áreas de solo raso, etc. Por exemplo, tem sido verificado em bacias florestadas que a partir de $50 \mathrm{~m}$. de distância do curso d'aqua, o runoff superficial começa a ser insignificante. Dai a necessidade de se manter devidamente protegida esta faixa ao longo dos cursos d'água.

MARINHO FILHO \& REIS (1989) afirmam que as matas ciliares săo tambem importantes para o desenvolvimento da fauna, a medida em que 0 seu arranjamento fisico funciona como "verdadeiros corredores", * propiciando a integração de animais de diferentes hábitats, o que contribui, de forma significativa, para a proteção do seu património genético. Ainda hoje, as matas de galeria são os hábitats em que se encontram a maiores riquezas e diversidade de espécies de mamiferos de areas abertas.

\subsection{O mecanismo da sucessão vegetal}

Para se sugerir modelos de revegetação e conservação de fragmentos e matas ciliares, é fundamental a compreensão do mecanismo de sucessão secundaria, pelo qual as florestas tropicais se auto-renovam. SHUGART (1982) apresenta dois modelos para o estudo da dinámica da vegetação: o modelo da floresta, na qual os atributos do "stand" florestal, tais como biomassa, número de árvores e os indices de diversidade estabelecem as variáveis a serem usadas como modelo; e um outro, que tenta simular a dinamica da floresta, comparando as variações de cada individuo arbóreo com o "stand" geral da população.

No estudo da sucessão, o autor chama a atenção para os atributos individuais de cada espécie, bem como para os diferentes processos de 
competição. A dinámica das florestas é devida a perturbações, que criam manchas sucessionais, cujo tamanho depende do tipo e severidade da perturbação. A morte natural ou acidental de uma ou mais ánores resulta em uma abertura no dossel da floresta: a clareira. Este processo de perturbação é discutido por BROKAW (1985), que descreve minuciosamente as diferentes maneiras de formação das clareiras, através da queda das ávores. Este autor salienta que à queda das ávores e ao ciclo de regeneração se associam três tipos de estrutura própria da floresta: fisionómica, populacional e da comunidade. Assim, a sucessão e o resultado de continuas perturbaçōes, fazendo da floresta um mosaico de claros, ou seja, um sistema em constante desequilibrio.

Tal desequilíbrio dinâmico certamente se opõe à afirmação de CLEMENTS (1916), de que a floresta, em seu estado natural, compōe-se um sistema climax. As clareiras apresentam um significativo aumento de luz, temperatura do ar e do solo, de entrada de água por precipitação, da disponibilidade de nutrientes e um decrescimo significativo da umidade relativa. Essas condições variam de acordo com o tamanho e a forma de cada clareira, que sấo reocupadas por diferentes grupos ecológicos (classes de tolerância) de espécies arbóreas, adaptadas para regenerar em clareiras de diferentes tamanhos (WHITMORE, 1977).

A primeira compreensão de que o grande número de especies da floresta poderia ser dividido em grupos, com funçóes diferentes para a sua renovação, através do mecanismo da sucessão secundária, foi relatada por BUDOWSKI (1984), que dividiu as especies florestais tropicais nos seguintes grupos sucessionais, a saber: a) pioneiros, b) secundarios iniciais, c) secundários tardios e d) clímaxes.

Seria esta a sequéncia que orienta 0 desenvolvimento da floresta, a partir de um distúrbio na mesma. Assim, após a formação de uma clareira, imediatamente inicia-se 0 aparecimento de um grupo de espécies pioneiras, que podem se originar de um banco de sementes no solo, ou através de outras formas de disseminaçâo. A capacidade das pioneiras de apresentar 
crescimento rápido em pleno sol faz com que elas colonizem em curto espaço de tempo as clareiras, facilitando o desenvolvimento das especies de fases sucessionais posteriores.

Para KAGEYAMA (1987), as caracteristicas mais conspicuas para os quatro grupos de BUDOWSKI e que têm mais implicação sobre a conservaçăo genética seriam as relativas a: a) número de especies da comunidade -1 a 5 nas pioneiras, até atingir mais de 100 nas clímaxes; b) ciclo de vida nas dominantes - menos de 10 anos nas pioneiras, ate 100 em 1000 ou mais, nas climaxes; c) tolerancia a sombra nas dominantes - muito intolerante nas pioneiras, ate toierante, nas climaxes; d) dispersão de sementes - passaros, morcegos e vento nás pioneiras e secundárias iniciais, passandio ao vento nas secundárias tardias e mudando para gravidade, mamiferos e roedores nas climaros; e) viabilidade das sementes - longa nas pioneiras e secundárias iniciais; pequena a média nas secundárias tardias e curta nas climaxes.

Estudos recentes têm demonstrado que a sucessão secundaria se apresenta de uma forma muito mais complexa e não tâo organizada como a descrita por BUDOWSKI. Assim, os estudos e análises de fragmentos florestais devem levar em conta as exigências especificas das especies vegetais ali existentes, definindo suas caracteristicas, principalmente em relação à luz, tendo como princípio o equilibrio e a estabilidade da população e, como meta, a conservação dos recursos naturais (KAGEYAMA, 1989).

DENSLOW (1985) afirma que a variação dos padrões de diversidade, aurante a sucessão, em comunidades de plantas, e devida aos eíeitos de seleção e da estratégia de história de vida, sobre diferentes regimes de distúrbios. A estratégia de história de vida de espécies de plantas depende, de alguma forma, de distúrbios para o estabelecimento de propágulos, devendo refletir a distribuiçû̀o do tamanho $c$ a frequencia dos claros e a taxa o escala desses disturbics 


\subsection{Aspectos da conservação da fauna}

Para FIRKOWSKI (1990), uma idéia que năo se pode perder de vista é que os animais, para obter alimento, dependem direta ou indiretamente da vegetação. Desta forma, e amplamente aceito o conceito de que, em geral, a diversidade de animais aumenta durante o processo de sucessão vegetal e atinge o máximo no clímax da vegetaçăo. Esta regra é válida para situaçóes em que a vegetaçăo, ocupando uma extensão considerável, vem se mantendo no estagio climax por algum tempo. Em áreas com vários estágios sucessionais, o esperado é que a diversidade animal seja mais elevada antes que toda a área atinja o último estágio sucessional.

Segundo este autor, todas as necessidades de um animal devem obrigatoriamente estar à sua disposiçăo dentro de um determinado espaço, seu territorio ou sua área de ocupaçăo, para que os recursos do hábitat sejam utilizados pelo individuo. A distribuiçăo dos fatores ou caracteristicas podem ser de suma importáncia. O fato de existir abrigo ou vias de escape junto ao alimento podem ser táo importantes quanto a existéncia do próprio alimento. Prover variedade e distribuiçăo dos tipos de vegetaçăo é o principio mais útil no manejo da fauna.

As áreas preservadas devem ser consideradas em termos de capacidade de suporte e de volume de hábitat e năo em termos de dimensăo. SICK (1985) cita por exemplo os perigos nas reservas com relaçáo à escassez de locais para nidificaçăo, a escassez de alimentos e a pressāo exercida por elementos imigrantes. A reduçăo da area leva constantemente ao empobrecimento local e à simplificaçăo dos ecossistemas.

PRESTON (1960) aponta o perigo da manutençăo de apenas porçóes de hábitat, apoiando-se em dados de estudos biogeográficos de "ilhas". Este autor ressalta os estudos de Darlington, os quais indicam que pequenas "ilhas" suportam menos espécies que as grandes; como regra geral, dividinda-se a área por 10, ocorre perda da metade das especies animais. 
As aves săo elementos importantes no estudo da avaliaçăo de qualidade dos ecossistemas, pois devido à diversidade de especies que ocupam os mais variados hábitats e niveis tróficos, são muito sensiveis às modificaçōes ambientais, sendo consideradas, portanto, excelentes bioindicadoras. Quaisquer alteraçఠes no ambiente de origem antrópica ou natural provocam variaçőes tanto quantitativas como qualitativas nas suas populaçóes, que são rápida $\theta$ facilmente observadas ( BEGE \& MARTERER, 1991).

ALMEIDA (1981) estudando a avifauna numa área defiorestada no municipio de Anhembi-SP, localizada na mesma regiăo da Estaçăo Ecológica de lbicatu, encontrou 169 espécies de aves, distribuldas em 151 gêneros, 42 familias e 17 ordens, predominando os passeriformes (90 espécies), em relaçăo aos náo-passeriformes ( 79 espécies). 0 autor constatou ainda que, de modo geral, os locais de vegetaçăo mais rica e de maior porte apresentavam os números mais elevados de especies; onde a vegetação era mais pobre e de menor porte, um número menor de espécies.

Comparando-se os dados levantados por ALMEIDA (1981) no mesmo estudo em pequenas formaçöes ciliares com os obtidos por WILLIS (1979) para a reserva de Barreiro Rico (contigua a Estação Experimental de Ciências Florestais em Anhembi-SP) com 1.400 ha. de área, verificou-se uma reduçăo média de espécies de aves de $53 \%$ e uma acentuada desorganizaçăo nas suas populaçరees, confirmando o efeito negativo ocasionado pelo pequeno tamanho e forma inadequada dos remanescentes florestais.

\subsection{Unidades de Conservação:}

\subsubsection{Evolução histórica}

Segundo DORST (1973), o conceito de proteçăo da natureza revelaria certamente que se trata de uma idéia já existente na Antigulidade. Os autores clássicos já haviam suscitado 0 interesse pelas devastaçóes cometidas na região mediterránea: contam que, certos locais, 
cobertos na epoca por cascalho estéril, apenas capaz de alimentar um pequeno número de cabras esqueléticas, estavam outrora cobertos de florestas onde brotavam nascentes que, entretanto, tinham secado.

LUNA (1977) conta que Platão há 2.300 anos indicava a necessidade de reflorestar as colinas de Ática, na Grécia, a fim de regular a provisăo de agua e prevenir a erosão. Relata, também, que a Índia mostra exemplos dignos de reconhecimento de áreas naturais, reservadas para total proteção de aves e outros animais e estabeleceu as chamadas "Abbayaranya", lugares onde os animais selvagens viviam livremente, sem nenhum temor do homem.

MACKINNON et alij (1986) relatam que no ano de 252 A.C. - Imperador Asoka, da Índia, promulgou um édito para a proteçăo dos animais terrestres, peixes e florestas. Este pode ser o mais antigo exemplo documentado de estabelecimento deliberado do que hoje se chama de áreas protegidas, mas a prática do estabelecimento ao lado de áreas sagradas como santuários religiosos ou reservas de caça exclusivas é muito mais antiga e a tradição continuou amplamente em muitas diferentes culturas até os dias presentes.

Segundo DORST (1973), essa tomada de consciencia amplificou-se na Idade Média. Inúmeros textos legislativos foram promulgados pelos principes, visando à proteçăo da fauna da Europa e a conservaçăo das nascentes que, em outras zonas, estavam sendo prejudicadas de forma generalizada. A maior parte dessas medidas tinha como objetivo principal a monopolização da grande fauna $\theta$ a preservação de terrenos de caça para o exclusivo beneficio dos grandes da época. Colocadas no seu contexto social, protegeram, no entanto a fauna de um modo bastante eficaz, moderando o processo de degradaçăo da natureza.

Para LUNA (1977), as primeiras medidas protecionistas foram tomadas na ldade Média, durante o século XIII, na Suiça, com o propósito de conservar seus bosques e seus passaros e, em 1569, estabeleceu-se neste 
pais a primeira reserva de caça no cantão suiço de Glaris, mantida até os nossos dias.

Segundo DORST (1973) e LUNA (1977), a primeira reserva natural foi criada na França, em 1853, quando um grupo de pintores franceses conseguiu que uma parte da floresta de Fontainebleau se tornasse protegida por lei com o proposito de manter intacta a beleza do lugar.

Entretanto, da forma pela qual se compreende atualmente a consenvação e o manejo de areas silvestres, o primeiro Parque Nacional do mundo, foi o "Yellowstone National Park", instalado em 1872, no nordeste de Wyoming, nos Estados Unidos. Para DORST (1973), o fato da criaçăo de reservas com vastas superficies ter surgido naquele pais se explica facilmente pelo contexto histórico e psicológico. No século passado, as devastaçőes catastróficas que ali ocorreram năo podiam deixar de desencadear reaçôes salutares. Por outro lado, os espaços livres eram ainda suficientemente vastos para permitir que fossem criadas reservas em grande escala.

Outros paises, ainda no final do século passado, seguiram o exemplo norte-americano, como o Canadá, que em 1885 criava o Parque Nacional de Banff, que fol o segundo do mundo (SILVA, 1992a). Em seguida, criaram seus Parques a Nova Zelândia, em 1894, a Austrália e a Africa do Sul, em 1898. Já na Europa, os Parques Nacionais como o dos Alpes, foram criados em 1914, com o objetivo de manter áreas naturais onde se pudessem realizar pesquisas de flora e fauna. No entanto, em nivel mundial, não havia definição universalmente aceita sobre os objetivos dos Parques Nacionais. Para definir o conceito foi convocada a Convenção para a Preservação da Flora e Fauna, em 1933, onde participaram também delegados das administraçóes coloniais africanas. Al definiram-se trés características do parque nacional: a) são areas controladas pelo poder público, b) para a preservação da fauna e flora, objetos de interesse estético, geológico, arqueológico, onde a caça é proibida e c) que devem servir à visitação pública (DIEGUES, 1993). 
De acordo com levantamento efetuado pela IUCN (Internacional Union for Conservation of Nature and Natural Resources), em 1985 as areas protegidas nas regióes tropicais somavam 1.420 e conservavam 174.098.572 hectares de terra e água. São nestas regióes, onde está concentrada grande parte da diversidade biológica do mundo, que se têm responsabilidade especial de assegurar a manutenção desta rica herança natural.

De modo geral, acredita-se que a América Latina, é indiscutivelmente é a mais significativa resenva florestal do mundo, pois cerca de metade da sua superficie é constituida de matas e de terras de vocaçăo florestal. Segundo DORST (1973), como a América do Sul começou a ser devastada pelo homem bem mais tarde do que outras partes do mundo, a constituiçăo de Parques Nacionais náo apresentou o mesmo caráter de urgéncia. Com um descaso sem dúvida lamentável, muitos governos latinoamericanos năo se preocuparam com esse problema que, no entanto, já se tornou inquietante.

Segundo MOORE \& ORMÁZABAL (1988), O México estabeleceu a Reserva Florestal Desierto de Los Leones em 1876, que foi transformada em 1917, em Parque Nacional.

Na Argentina, em 1903, Francisco P. Moreno havia doado ao seu pais um vasto território nos Andes, esboço do famoso Parque Nacional de Nahuel Huapi, criado oficialmente em 1934, cobrindo uma superficie de 785.000 ha.

No Chile, a primeira área silvestre protegida foi a Reserva Florestal Malleco, criada em 1907. Em 1912, foi criada a Reserva Florestal Villarica, transformada em 1925 no primeiro Parque Nacional daquele país.

O Equador criou em 1934 o seu primeiro Parque Nacional, denominado Galápagos, no arquipelago do mesmo nome, enquanto que o Brasil 
e a Venezuela somente criaram seus primeiros Parques Nacionais mais tarde, em 1937 (MOORE \& ORMAZÁBAL, 1988).

Segundo MILANO (1990), o Brasil embora com toda a sua diversidade ecológica e de ambientes cénicos notáveis, criou seu primeiro Parque Nacional, o de Itatiaia, somente em 1937 e hoje, passados mais de 50 anos, conta com um sistema de Unidades de Conservaçăo que protege aproximadamente apenas $3,8 \%$ do território nacional, valor aquém da média latinoamericana. Com a criaçăo do Parque Nacional do Itatiaia (RJ), instituiu-se a proteção de áreas naturais no pais, seguindo-se em 1939 a criaçăo dos Parques Nacionais do lguaçu (PR) e Serra dos Órgăos (RJ). A partir desta iniciativa, transcorreu um período de 20 anos até que sejam instalados novos Parques Nacionais.

Segundo este autor, durante este longo intervalo de 20 anos, foi iniciado o processo de criaçăo de outras Unidades de Conservaçăo, como as Reservas Biologicas (RB) e as Florestas Nacionais (FLONAS). Estas, muito vezes desconsideradas como Unidades de Consenvação, tiveram sua instituiçăo iniciada em 1946, com a criação da Flona de Araripe (CE), passandose mais de uma década até a criaçăo de novas Unidades.

Em 1959, foram criados outros Parques Nacionais como o de Aparados da Serra (RS/SC), Araguaia, na liha do Bananal, em Goiás e o de Ubajara, no Ceará (SILVA, 1992a). Até entâo, a grande maioria deles se concentrava nas regióes sul e sudeste, a mais desenvolvidas do pais. Mas, a partir da década de 60 , com a expansão das fronteiras agricolas, que exigiu a derrubada de grandes áreas de vegetaçăo natural, começaram a ser implantados muitos outros parques em várias regióes do Brasil.

Em 1965, o novo Código Florestal definiu como Parques Nacionais as áreas criadas com a finalidade de resguardar atributos excepcionais da natureza, conciliando a proteçăo integral da flora, da fauna e das belezas naturais com a utilizaçăo para objetivos educacionais, recreativos e 
cientificos. Nesse ano, já haviam sido criados 15 Parques Nacionais e 4 Reservas Biologicas (QUINTTÃO, 1983).

Em 1979, o Instituto Brasileiro de Desenvolvimento Florestal - IBDF - que desde 1967 era responsável pela administração das Unidades de Conservaçăo - elaborou o Plano de Sistema de Unidades de Conservação no Brasil, cujo objetivo principal era o estudo detalhado das regiōes propostas como prioritárias para a implantação de novas unidades. Alem disto, o Plano se propunha a rever as categorias de manejo até então existentes, uma vez que as duas únicas existentes (Parques Nacionais e Reservas Biologicas) eram consideradas insuficientes para cobrir a gama de objetivos propostos (IBAMA) FUNATURA, 1989). Nesse plano foi recomendada a criaçăo de outros tipos de Unidades de Conservação, mas a legislaçăo correspondente năo seguiu a recomendação (DIEGUES, 1993).

Para este autor, um dos grandes paradoxos desse processo e que a partir de 1967, ate a criação do IBAMA (Instituto Brasileiro do Meio Ambiente), em 1989, coube ao IBDF (instituto Brasileiro para o Desenvolvimento Florestal) a implantação e administração das Unidades de Conservaçăo. Esse órgão federal era comprometido com o desmatamento de grandes áreas de florestas naturais para a implantação de projetos de reflorestamento para fins industriais.

Ainda DIEGUES (1993) conta que houve grande impulso à criaçăo de Unidades de Conservação nas décadas de 70 e 80 de 1970 a 1979 foram instituldas 11 ; e de 1980 a 1989 , surgiram 58 . Citando GUIMIRE (1991), - autor ressalta que houve uma combinação de fatores que explicam esse aumento da preocupação mundial pelas Unidades de Conservação; a rápida devastação das florestas e a perda da biodiversidade, a disponibilidade de fundos internacionais para a conservação e a possibilidade de geraçâo de renda pelo turismo em parques.

A partir de 1983 são instituldas no pals as categorias de Estaçăo Ecologica e Área de Proteção Ambiental (APA) e se acelera o processo 
de criação de novas Unidades de Conservação das diferentes categorias de manejo (MILANO, 1985).

Em 1989, o IBAMA encomendou à FUNATURA, organização nấo-governamental, uma reavaliação do Plano de Sistema de Unidades de Conservaçáo estabelecido em 1979, mas o documento não saiu do papel (DIEGUES, 1993).

Para este autor, o Brasil contava em 1990 com cerca de 15 tipos, englobando cerca de 429 Unidades de Conservaçăo, em nivel federal, estadual ou municipal, ocupando 48.720 .109 ha. Cerca de 40.000 .000 hectares se encontram na Região Amazónica, onde existem somente 72 Unidades de Conservação $(91,7 \%)$, comparando-se por exemplo, com a região sul-sudeste que tem mais de $80 \%$ do total das Unidades de Conservação, apesar de ocuparem uma area de cerca de 4.043 .390 (ou $8 \%$ do total das Unidades de Conservação (Bacha, citado por DIEGUES, 1993). Segundo SILVA (1992), até agosto de 1990, o Brasil possula 34 Parques Nacionais e 23 Reservas Biologicas que representam um total de 12,8 milhões de hectares.

De acordo com MILANO (1990), o Estado de São Paulo, conforme dados da SEMA (1988), com 2.643.615 hectares de areas de Unidades de Conservação das diferentes categorias de manejo têm protegido aproximadamente $10 \%$ do território estadual, o que, sob vários aspectos pode sofrer contestação, uma vez que a cobertura florestal remanescente no Estado é estimada em 5 a $7 \%$ da extensão territorial. Para SILVA \& FORNASARI FILHO (1992), no Estado de São Paulo existem atualmente (1991) 205 Unidades de Conservação, distribuidas em 190 municípios, tanto da administração federal como da estadual.

De acordo com O FUNDO DE DESENVOLVIMENTO FLORESTAL (1993b) - no informativo quadrimestral sobre o setor florestal paulista - as áreas protegidas no Estado de São Paulo, tanto públicas como privadas, somaram 1.307 .893 hectares, cuja distribuição pode ser verificada na Tabela 2: 
Tabela -2 AREAS PROTEGIDAS DO ESTADO DE SÃO PAULO*

\begin{tabular}{|c|c|c|}
\hline Denominação & Area (ha) & Percentual $(\%)$ \\
\hline Estacoes ecologicas ( 1 ) & 106.043 & $8.108 \%$ \\
\hline Parques (1) & 758.159 & $57,988 \%$ \\
\hline Reservas biologicas (1) & 2.300 & $0,178 \%$ \\
\hline Reservas florestais oficiais (1) & 47.991 & $3,889 \%$ \\
\hline Sub Total & 914.493 & \\
\hline \multicolumn{3}{|l|}{ Reservas florestais privadas: } \\
\hline Areas averbadas (2) & 269.744 & $20,824 \%$ \\
\hline $\begin{array}{l}\text { Areas conserv.jpreservaço de } \\
\text { empresas florestais }(3)\end{array}$ & 80.426 & $8,149 \%$ \\
\hline Area recuperada CESP (4) & 4.876 & $0,373 \%$ \\
\hline $\begin{array}{l}\text { Unidade de Conservação (Fazenda } \\
\text { Intervales (5) }\end{array}$ & 38.354 & $2,933 \%$ \\
\hline Sub total & $393.400^{x}$ & \\
\hline Total & 1.307 .893 & \\
\hline
\end{tabular}


(Continuação): Tabela 2 - Áreas protegidas do Estado de São Paulo

Observações:

*Sob administração direta: federal, estadual e privada

( $)$ Pode haver superposição de areas no cálculo deste valor.

Fontes:

(1) Áreas naturais sob Proteção no Estado de São Paulo, série cartográfica CPRN/PRISMA

(2) DEPRN (acumulado de 1983 a abril de 1993)

(3) APFPC/ANFPC - 1992

(4) CESP (acumulado ate março de 1993)

(5) FF-1987 


\subsection{Conceituação e objetivos das Unidades de Conservação}

Segundo GOUVEA (1985), a IUCN (União Internacional para Conservação da Natureza) define conservação como "a gestão da utilização da biosfera pelo ser humano, de tal sorte que produza o maior beneficio sustentado para as gerações atuais, mas que mantenha sua potencialidade para satisfazer as necessidades e as aspirações das geraçóes futuras. Portanto, a conservaçâo é positiva e compreende a preservaçăo, a manutenção, a utilização sustentada, a restauração e a melhoria do ambiente natural".

Segundo SILVA \& FORNASARI FILHO (1992), o Poder Público tem criado sistematicamente Unidades de Consenvaçăo Ambiental no território nacional, com o intuito de proteger determinadas áreas, que apresentam caracteristicas singulares do ponto de vista ambiental, seja por conter ecossistemas frágeis, locais de reprodução de fauna, hábitats de importancia para a naçăo, ou outro aspecto qualquer que seja julgado relevante e que justifique sua proteção.

Normalmente, as Unidades de Conservaçăo săo instaladas em areas silvestres. Para Miller, citado por ALMEIDA (1983) as areas silvestres são terras virgens, destruidas, alteradas, abandonadas ou marginais, podendo ser florestadas, deserticas, pantanosas ou montanhosas, que por seu valor em termos dos recursos apresentados, devem ser mantidas em forma silvestre, sob um regime apropriado de manejo.

THELEN \& DALFELT (1979) definem areas silvestres como "áreas naturais não submetidas atualmente a um emprego intensivo para fins agricolas ou florestais". SILVA (1992a) complementa dizendo que os beneficios obtidos a partir destas áreas são de difícil quantificação, uma vez que o capital 
utilizado é o capital natural, diferente dos benefícios concedidos pelo emprego de técnicas económicas.

Em funçăo da avaliação das caracteristicas de um determinado ecossistema, de sua vocaçăo e da destinaçăo que efetivamente se pretende dar a ele, as Unidades de Conservaçăo conterăo diferentes graus de restriçáo de uso do solo e dos recursos naturais ali existentes, percorrendo toda uma gama de limitaçóes, que váo desde a proibiçăo total de sua utilizaçáo, destinando-se a área a preservaçăo integral da biota, passando por categorias de manejo, onde se permite a pesquisa cientffica e outras, onde se possibilita 0 uso recreativo, educativo e turístico, chegando a Unidades de Conservaçăo que admitem até mesmo alguma forma de exploraçâo económica (GOUVÉA, 1985).

Para MILANO (1990), considera-se o Sistema Nacional de Unidades de Conservaçăo 0 conjunto de unidades que, devidamente selecionadas, planejadas e manejadas como um todo, é capaz de viabilizar em objetivos nacionais de conservaçăo. $O$ sistema refere-se, portanto, a um conjunto de unidades articuladas, tanto geograficamente como por categorias de manejo. Ainda segundo este autor, em nível institucional, o Sistema Nacional de Unidades de Conservaçăo do Brasil começou a ser estabelecido no final da década de setenta, quando o "diagnóstico do subsistema de conservaçăo e preservação de recursos naturais renováveis" considerou a eliminação do processo casulstico de seleção de áreas para fins de proteçăo e definiu as diretrizes de planejamento sistemático para tal fim, cujos estudos iniciaram dois anos antes (IBDF, 1978).

Para SILVA e FORNASARI FILHO (1992) o Plano de Sistema de Unidades de Conservação do Brasil - II Etapa do Instituto Brasileiro de Desenvolvimento Florestal - IBDF - e da Fundaçăo Brasileira para Conservaçáo da Natureza - FBCN (1981) e considerado um dos mais completos trabalhos existentes atualmente no Brasil sobre o assunto, em nivel conceitual, sendo ainda utilizado na criação de novas Unidades de Conservação. Conforme apresentado no referido plano, existem determinados objetivos, que elas devem atingir, a nivel nacional. Estes objetivos são os seguintes: 
- proteger as amostras de toda a diversidade de ecossistemas do pais. assegurando o processo evolutivo;

- proteger espécies raras em perigo ou ameaçadas de extinçáo, biótopos, comunidades bióticas unicas, formaçōes geológicas e geomorfologicas de relevante valor, paisagens de rara beleza cênica, objetivando garantir a autoregulaçāo do meio ambiente, como tambem um meio diversificado;

- preservar o património genético, objetivando a redução das taxas de extinção das especies a niveis naturais:

- proteger a produção hídrica, minimizando a erosão, a sedimentação, especialmente quando afeta atividades que dependam da utilização da água e do solo:

- proteger os recursos da fiora e da fauna, quer seja por sua importancia genética, ou pelo seu valor económico, obtenção de proteinas ou para atividades de lazer;

- conservar as paisagens de relevantes belezas cenicas, naturais ou alteradas, mantidas em nivel sustentavel, visando a recreação ou o turismo;

- conservar valores naturais, históricos e arqueológicos para investigação e visitação;

- preservar grandes áreas provisoriamente, ate que estudos futuros indique sua melhor utilizaçá;

- levar o desenvolvimento, atraves da conservação, a areas até então pouco desenvolvidas;

- propiciar condiçóes de monitoramento ambiental; 
- propiciar meios para evoluçăo, investigaçăo, estudos e divulgaçăo sobre os recursos naturais;

- fomentar o uso racional dos recursos naturais, através de áreas de uso múltiplo.

\subsubsection{Classificação das Unidades de Conservação:}

MOORE \& ORMAZÁBAL (1988) encontraram 69 diferentes categorias de manejo em 19 paises da América Latina. Da análise destas 69 categorias concluiram que muitas delas săo muito parecidas entre si, chegando em alguns casos a apresentar subdivisóes cada vez mais sutis de uma categoria global. Em outros casos, o nome de uma categoria năo significa uma mesma forma de manejo em todos os palses. Isto dificulta o planejamento e o manejo eficiente das áreas protegidas.

MILANO (1990) afirma que o pais conta naquela data com uma situação confusa quanto ao elenco de categorias de manejo conceitual e legalmente constituido. Juntamente com categorias de manejo claramente conceituadas $\theta$ adotadas, existem categorias mal definidas e sem uma clara conceituaçăo. Ao passo que existem categorias distintas pelas denominaçōes adotadas, embora semelhantes pelos objetivos de manejo, outras, fundamentais, năo foram instituldas.

GOUVÉA (1985) observa que a confusăo de conceitos relativos as diversas categorias de manejo se justifica pela necessidade da tomada de medidas emergenciais, coibindo o uso ou o abuso do solo e dos recursos naturais em areas ou situaçóes onde se impunha alguma forma de proteçăo ambiental, assim como pela preméncia de criaçăo de Unidades de Conservaçăo, que possibilitassem o adequado (ou, pelo menos controlado) manejo destes recursos.

SILVA (1992a) diz que a açáo de diferentes correntes de pensamento a respeito da definição e caracterização das áreas silvestres tem 
como resultado um considerável número de áreas com nomes diferentes, com características e objetivos identicos ou que apresentam em comum apenas a denominação, embora inúmeras conferencias, congressos e encontros tenham se realizado, visando a unificação. Nem todas as Unidades de Conservação previstas pelas organizaçōes internacionais são adotadas no Brasil, outras existem com adaptaçóes conceituais previstas ou não em legislaçăo própria. De acordo com este autor, para classificação das áreas silvestres no Brasil em categorias de manejo, o Instituto Brasileiro para o Desenvolvimento Florestal (IBDF) seguiu as orientaçóes contidas em documento preparado pela IUCN de onde foram extraidos subsídios para a elaboração do Sistema de Unidades de Conservação da Natureza, com as devidas adaptações, quando necessárias. As areas silvestres foram agrupadas e apos caracterizadas segundo as categorias de manejo que se seguem:

a) Categorias de manejo de importância nacional:

- Monumento Natural

- Parque Nacional

- Reserva Biológica

- Santuário ou Refúgio da Vida Silvestre

As principais caracteristicas desse grupo são: a proteçăo total dos recursos naturais; o uso indireto dos recursos naturais; observar a evoluçăo dos ecossistemas ou parte deles, mantendo-os em estado natural; as terras devem pertencer à União, exceto para o caso de Santuário da Vida Silvestre, onde nem sempre a aquisiçăo pelo poder público é necessária.

b) Categorias de manejo complementares: 
- Estaçåo Ecológica

- Estrada Parque

- Reserva de Recursos (Reserva Florestal)

- Rio Cénico (Rio Nacional)

As caracteristicas principais desse grupo săo a proteção parcial dos recursos naturais; 0 uso indireto dos recursos naturais; $e$ onde 0 ambiente pode apresentar alterações antrópicas.

c) Categorias de manejo adicionais:

- Floresta Nacional

- Monumento Cultural (sitios históricos)

- Parque de Caça

- Parque Natural

- Reserva de Fauna

- Reserva Indigena

As características desse grupo são o uso direto dos recursos naturais através do manejo sustentado; as terras podem pertencer ao governo ou a este a a particulares conjuntamente; năo são consideradas Unidades de Conservaçăo na totalidade da concepçăo do termo, mas podem contribuir para o sistema.

d) Categorias de manejo regionais ou locais:

- Reserva Biológica Estadual 
- Reserva Biológica Municipal

- Parque Estadual

- Parque Municipal

- Parque de Caça Estadual (ou Municipal)

- Outras Unidades

São categorias de conservação pertencentes a outras esferas de poder, que não o federal.

e) Categorias de manejo de importância mundial:

- Resena de Biosfera

- Reserva do Patrimonio Mundial

Para SILVA \& FORNASARI FILHO (1992), as Unidades de Conservação propriamente ditas, assim denominadas pelo Conselho Nacional do Meio Ambiente, atraves de resoluções são:

- Áreas de Proteção Ambiental - APA

- Áreas de Relevante Interesse Ecológico - ARIE

- Estação Ecológica

- Floresta Estadual (ou Municipal)

- Floresta Nacional

- Horto Florestal 
- Jardim Botánico

- Jardim Zoológico

- Monumento Natural

- Parque Estadual ( ou Municipal)

- Parque Nacional

- Reserva Biológica

- Reserva Ecológica

\subsubsection{Estação Ecológica:}

Para SILVA \& FORNASARI FILHO (1992) as Estaçóes Ecologicas săo Unidades de Conservaçăo implantadas e estruturadas, visando permitir estudos comparativos com as areas da mesma regiăo, ocupadas e modificadas pelo homem, a fim de que informaçőes úteis aos planejamento regional e ao uso racional dos recursos naturais sejam obtidas.

A idéia de se criar Estaçóes Ecológicas no Brasil surgiu na década de 70, com a implantação do Programa de Estações Ecológicas, efetuado pela Secretaria Especial do Meio Ambiente - SEMA. As primeiras unidades a serem oficializadas foram as de Taim e a de Aracuri, ambas no Rio Grande do SUl, em 1974 (MINISTÉRIO DO INTERIOR, SEMA, 1980).

O objetivo desse programa era de "preservar ambientes naturais, representativos dos nossos ecossistemas, destinados a servir como infraestrutura as Universidades para promoçăo de estudos ecológicos comparativos entre a situaçăo encontrada nessas áreas protegidas e as áreas vizinhas ocupadas pelo homem. Pretendia também incrementar uma tecnologia 
nacional de controle do meio ambiente, atraves do estudo do comportamento dos elementos constituintes dos ecossistemas brasileiros" (1977).

Dentro deste Programa, a SEMA criou várias Estaçôes Ecológicas em todo o pais. MILANO (1982) registrou em 1981 a existência de onze destas unidades instaladas, duas em fase de implantação e mais 20 areas em estudo.

Para GOUVÊA (1985) a expressão "Estação Ecológica" foi usada, por mais de uma vez, em legislação nacional, antes que sua base legal fosse estabelecida, como por exemplo na Lei $n^{\circ} 6.513$, de 20/12/1977, que dispóe sobre a criação de areas especiais e de Locais de Interesse Turístico (item 4.9.)

No entanto, as Estações Ecológicas foram efetivamente criadas pela Lei $n^{\circ} 6902$, de 27 de abril de 1981, que estabelece:

Artigo $1^{\circ}$ - Estações Ecologicas são areas representativas de ecossistemas brasileiros, destinadas à realizaçáo de pesquisas básicas e aplicadas de ecologia, a proteção do ambiente natural e ao desenvolvimento da educação conservacionista.

Paragrafo $1^{\circ}-90 \%$ (noventa por cento) ou mais da area de cada Estação Ecológica, será destinada, em caráter permanente, e definida em Ato do Poder Executivo a preservação integral da biota;

Paragrafo $2^{\circ}$ - Na area restante, desde que haja um plano de zoneamento aprovado, segundo se dispuser em regulamento, poderá ser autorizada a realização de pesquisas ecológicas que venham a acarretar modificações no ambiente natural.

Parágrafo $3^{\circ}$ - As pesquisas científicas e outras atividades, realizadas nas Estaçóes Ecologicas, levarão sempre em conta a necessidade de não colocar em perigo a sobrevivencia das populacoóes das espécies ali existentes. 
Artigo $2^{\circ}$ - As Estações Ecológicas serão criadas pela União, Estado e Municipios, em terras de seus domínios, definidos no ato de criação seus limites geográficos e o órgão responsável pela sua administração.

Artigo $3^{\circ}$ - Nas áreas vizinhas às Estações Ecológicas, serão observados para a proteção da biota local, os cuidados a serem estabelecidos em regulamento, e na forma prevista, nas leis $n^{\circ} \mathrm{s} 4.771$, de 15 de setembro de 1965 e 5.197 , de 3 de janeiro de 1967.

Artigo $4^{\circ}$ - As Estaçôes Ecológicas serão implantadas e estruturadas de modo a permitir estudos comparativos com as areas da mesma região ocupadas e modificadas pelo homem, a fim de obter informações úteis ao planejamento regional e ao uso racional de recursos naturais.

Artigo $5^{\circ}$ - Os órgãos federais financiadores de pesquisas e projetos no campo da ecologia, darão atenção especial aos trabalhos científicos a serem realizados na Estações Ecológicas.

Artigo $6^{\circ}$ - Caberá ao Ministério do Interior, através da Secretaria Especial do Meio Ambiente (SEMA), zelar pelo cumprimento da destinação das Estações Ecologicas, manter organizado o cadastro das que foram criadas e promover a realização de reuniões cientificas, visando a elaboração de planos e trabalhos a serem nela desenvolvidos.

Artigo $7^{\circ}$ - As Estações Ecológicas não poderão ser reduzidas nem utilizadas para fins diversos daqueles para os quais foram criadas.

Parágrafo $1^{\circ}$ - Nas áreas reservadas às Estações Ecológicas será proibido:

a) Presença de rebanho de animais domésticos de propriedade particular;

b) Exploração de recursos naturais, exceto para fins experimentais, que não importem em prejuizo para a manutenção da biota nativa, ressaivado o disposto no Parágrafo $2^{\circ}$ do Artigo $1^{\circ}$; 
c) O porte e uso de armas de qualquer tipo;

d) O porte e uso de instrumentos de corte de árvores;

e) O porte e uso de redes de apanha de animais e outros artefatos de captura.

Parágrafo $2^{\circ}$ - Quando destinados aos trabalhos cientificos e à manutenção da Estação, a autoridade responsavel pela sua administração, podera utilizar o uso e o porte dos objetos mencionados nas alineas " $c$ ", " $d$ " e " $e$ " do paragrafo anterior.

Parágrafo $3^{\circ}$ - A infração às proibições estabelecidas nesta Lei sujeitará 0 infrator à apreensão do material proibido pelo prazo de 1 (Um) a 2 (Dois) anos e ao pagamento de indenização pelos danos causados.

Parágrafo $4^{\circ}$ - As penalidades previstas no paragrafo anterior, serão aplicadas pela administração da Estação Ecológica. [..]

O artigo 30 do Decreto $88.351 / 83$ estabelece que "nas áreas circundantes das Estações Ecológicas, num raio de 10 quilômetros, qualquer atividade que possa afetar a biosfera, ficará subordinada às normas editadas pelo CONAMA (Conselho Nacional do Meio Ambiente, criado pela Lei 6.938 , de 31/8/1981), no ambito de sua competencia."

Para GOUVÊA (1985) embora as Estaçóes Ecologicas sejam implantadas em terras de dominio público, 0 uso de seu entorno permanecera sob controle, impondo-se al, limitaçóes administrativas ao exercício do direito de propriedade. A espécie ou o alcance de tais limitações, além de serem definidas pelo CONAMA, sem dúvida, dependerão da área abrangida e das necessidades de cada entorno.

Segundo SILVA \& FORNASARI (1992) a Resolução CONAMA $10 / 87$ determina que as empresas implantem Estação Ecologica quando da construçáo de empreendimentos que causem danos a florestas e a 
outros ecossistemas. A Estação deve localizar-se preferencialmente, junto à área do empreendimento e será administrada diretamente pela empresa ou através de convênio com o órgão ambiental responsável. Esta norma vigora sobre obras de grande porte, assim definidas com fundamentação no Relatório de Impacto Ambiental (RIMA), que deve conter, inclusive, alternativas para sua implantaçăo.

A Resoluçăo $n^{\circ} 3$ (CONAMA), de 16 de março de 1988 estabelece no seu Artigo $1^{\circ}$ que "as entidades civis com finalidades ambientalistas poderăo participar da fiscalizaçăo de Reservas Ecológicas públicas ou privadas, Áreas de Proteção Ambiental, Estaçōes Ecológicas, Áreas de Relevante Interesse Ecológico, outras Unidades de Conservaçăo e demais áreas protegidas.

De acordo com o Decreto $n^{\bullet} 99.274$ de 6 de junho de 1990 , que regulamenta a Lei $n^{\circ} 6.092$ de 27/04/1981 e a Lei $n^{\circ} 6.938$, de 31/08/1981, que dispóe respectivamente sobre a Criaçăo de Estaçóes Ecologicas e Áreas de Proteçăo Ambiental e sobre a Polltica Nacional do Meio Ambiente, estabelece-se no Titulo II - Das Estaçóes Ecológicas e das Áreas de Proteção Ambiental - no Capitulo 1- Das Estaçōes Ecologicas, Artigo 27, que nas áreas circundantes das Unidades de Conservação, num raio de dez quilómetros, qualquer atividade que possa afetar a biota ficara subordinada as normas do CONAMA, reafirmando assim, mais uma vez, a competéncia do setor público para efetuar o controle e a fiscalizaçăo ambiental nas áreas circunvizinhas as Estaçőes Ecológicas, visando a sua efetiva conservaçăo.

O Conselho Nacional do Meio Ambiente - CONAMA, através da Resolução $n^{\circ} 13$, de 6/12/1990, considerando o disposto nos artigos $7^{\circ}$ e 27 , Decreto $n^{\circ} 99.274$, de 6/6/1990 e considerando a necessidade de estabelecerse, com urgéncia, normas referentes ao entorno das Unidades de Conservaçăo, visando a proteção dos ecossistemas ali existentes, resolve:

Artigo $1^{\circ}$ - O órgão responsável por cada Unidade de Conservaçăo, juntamente com os orgâos licenciadores e de meio ambiente, definira as atividades que possam afetar a biota da Unidade de Conservação. 
Artigo $2^{\circ}$ - Nas áreas circundantes de Unidades de Conservaçăo, num raio de dez quilómetros, qualquer atividade que possa afetar a biota deverá ser obrigatoriamente licenciada pelo orgão ambiental competente.

$\S$ Único - O licenciamento a que se refere o "caput" deste artigo, só será concedido mediante autorização do órgão responsável pela administraçăo da Unidade de Conservação.

Segundo AGUIAR (1994), é preciso ressaltar que as Unidades de Conservaçăo, ainda que criadas por decreto, só poderăo ser alteradas ou suprimidas por lei, conforme comando do artigo $225,1^{\circ}$, III da Constituição Federal.

2.6. Planejamento ambiental das áreas silvestres:

Stone, citado por PENNA (1971), observa que planejar consiste em reunir e analisar informaçóes pertinentes aos objetivos visados, acompanhados de conclusóes que permitirăo estabelecer a norma de açâo futura.

O planejamento é um processo sistematizado, através do qual poderemos dar maior eficiência a uma atividade, permitindo, num prazo maior ou menor, alcançar um conjunto de metas estabelecidas. Suas características próprias sáo: ineréncia, globalidade, unidade, dinamismo, viabilidade, previsåo e participação (CARVALHO, 1971).

Para FRIEDMAN (1971), todo plano é principalmente um meio para comunicar certas informaçőes e para coordenar a ação com as metas previamente escolhidas. Um plano é, assim, usualmente, um documento de considerável extensấo, com numerosos e diferentes tipos de informaçб̋es, tais como: análise e identificação de problemas; consequencias futuras das principais variáveis; uma fixação de metas, objetivos e alvos; uma relaçăo de padróes e prioridades de açăo; e um esboço de orçamento, com a distribuição dos recursos financeiros para projetos e atividades. A durabilidade de um plano 
é. entretanto, limitada. Cedo ele se torna desatualizado. De tempos a tempos, tera de ser revisto, a medida que se obtenham novas informaçōes, os projetos sejam completados e a situação modificada.

Para LUNDEEN \& DEVILBISS (1979), em qualquer planejamento ou situação de tomada de decisóes, é essencial ter uma compreensão dos problemas a serem resolvidos. A definição do problema tornase a estrutura, dentro da qual acontecem todas as atividades dos processos de planejamento.

Em sintese, para WOMBLE (1979) qualquer planejamento que ignora as necessidades da população local, que não proporciona sua participação, ou coloca o controle e tomada de decisões totalmente fora da área afetada, tem pouca chance de sucesso.

Para SEIBERT (1974), o manejo do ambiente é considerado como um componente num planejamento geral da organização dos espaços. $O$ planejamento da paisagem e a organização dos espaços procuram, com seus programas e suas medidas, organizar o espaço vital do homem. A finalidade do planejamento da paisagem é de se achar um equilibrio, entre o potencial natural da paisagem e as necessidades da sociedade. Segundo este autor, de modo generalizado, pode-se adotar a seguinte regra: "quanto mais nos encontramos em regiōes urbanas e áreas artificiais, tanto mais liberdade temos para trabalhar, sem consideraçóes básicas concernentes à natureza. Quanto mais penetramos na paisagem livre e intocada, tanto mais precisamos executar uma proteção no sentido de nos fixarmos nos padrōes da natureza."

O planejamento ambiental, para SANTOS et alii (1975), não deve ser uma atividade puramente reflexiva, ou seja, o esforço dirigido unicamente ao controle da poluição ou degradaçáo ambiental; também não deve ser encarado numa ótica economicista, cuja abordagem reduziria os esforços da planificaçâo a termos estritamente utilitaristas, onde 0 ambiente fisico e social seriam partes a equilibrar para maior rendimento e longevidade da engrenagem economica. Portanto, não se trata apenas de um planejamento 
territorial, econômico, social, etc. Porém de um estilo interdependente de planejamento, integral e não setorial, havendo uma interrelação entre os fatores económicos, sociais, culturais e ambientais que atuam no conjunto do processo de desenvolvimento.

Segundo GUILLAUMON (1982), o desenvolvimento dos planos deve visar a minimizaçăo de conflitos e efeitos indesejáveis pela coordenação de objetivos políticos de planos setoriais e de programas. A qualidade do meio ambiente é influenciada pelos assentamentos humanos, mas a eficiencia com que as atividades humanas são desenvolvidas, é também refiexo do meio ambiente. Para esse autor, o planejamento de uso do solo deve ser feito a compatibilizar as formas de ocupação humana, que são eutroficantes e poluidoras, à vocação do sitio e a tecnologias de depuraçăo e reciclagem, minimizando sobrecargas aos sistemas de biodegradaçăo natural.

GRÖNING \& NOHL (1972), entendem que o planejamento de espaços livres e aquele que nessa tarefa, considera os aspectos culturais, ecológicos, económicos, estéticos e sociais ligados a esses espaços. Como espaços livres, consideram todas as áreas não ocupadas ou construídas.

Para CAVALHEIRO (1982), é Bannon, que consegue chegar a uma conscientização mais precisa, deixando claro que o espaço livre somente vem a sé-lo, como elemento de planejamento ou de processo de "design". Dessa forma, estão abordados desde os espaços livres naturais (Parques Nacionais, Estaçōes Ecológicas, etc.), até os urbanos.

Segundo SILVA (1992a), o conjunto de normas que versa sobre a manipulação de cada local ou o conjunto de atividades nas áreas silvestres denomina-se Plano de Manejo, o qual deve ser escrito e precisa conter claramente o que, quando, onde e quem deve executar as ações para que náo ocorram desequilibrios entre a administração, a natureza e o público.

Segundo MOORE \& ORMAZÁBAL (1988) para cada Unidade Conservação deve-se preparar um Plano de Manejo; eles devem ser 
orientados basicamente a apresentar uma planificação conceitual do manejo de cada area individual, baseada nos objetivos de manejo que sua categoria implica.

GOLDENSTEIN (1982) reforça esta idéia afirmando que os Planos de Manejo devem ter a preocupação de respeitar as estruturas sociais e económicas das populaçóes locais, assim como a sua dinâmica. Devem esses planos ser suficientemente flexiveis para prever nas paisagens tombadas, zonas de uso heterogêneo, com diferentes graus de restrição.

Segundo BARBORAK et alii (1982) o primeiro passo para planificação operativa para Áreas Silvestres, como Parques Nacionais, Reservas Biológicas e Áreas Recreativas Nacionais é preparar uma descrição concisa do contexto regional no qual esta situada a area, dos seus recursos naturais e culturais, do atual uso do solo e dos principais problemas do manejo. E' preciso também conhecer 0 corpo de funcionários disponiveis e a infra-estrutura existente. A partir disso, define-se os objetivos e prepara-se os programas e subprogramas de manejo para a área.

Para DIEGUES (1993), até hoje, no Brasil, a avaliaçăo de uma area a ser declarada Unidade de Conservaçăo tem sido responsabilidade única dos cientistas naturais. E' necessária uma visão interdisciplinar, onde trabalhem de forma integrada biólogos, engenheiros florestais, sociólogos, antropólogos e cientistas políticos entre outros. Segundo este autor, há necessidade de se pesquisar melhor as influéncias humanas, passadas e presentes, nas "areas naturais, os sistemas tradicionais e modernos de manejo e conservação, as diversas percepções existentes, as populaçōes tradicionais sobre a conservação e uso dos recursos naturais, os mitos e crenças que podem facilitar uma real participação das populaçōes locais no planejamento e implantaçăo de Unidades de Conservaçăo.

Ainda DIEGUES (1993), afirma que em 1982, somente a metade dos Parques Nacionais e Reservas Biológicas contavam com planos de manejo e assim mesmo, raros são os planos realmente implantados. Grande 
parte dessas Unidades apresentam problemas sérios de degradação. Segundo BACHA (1992), estes problemas seriam: fiscalização deficiente, morosidade do Governo em resolver a situação fundiária e predominancia dos interesses econômicos sobre os de conservação. Além disso, este autor afirma que o governo tem criado Unidades de Conservaçáo sem um conhecimento adequado das populaçóes que vivem dentro dessas áreas. Inexistem estudos sistemáticos sobre os processos de degradação das Unidades de Conservação, mas por algumas informações disponiveis, constata-se que a maior parte das agressóes partem de grupos de interesse e atividades externas as Unidades de Conservação (pecuaria extensiva, contaminação por agrotóxicos, vinhoto, invasão de madeireiros, garimpeiros, vazamento de óleo, barragens, estradas, caça esportiva) e não das populações tradicionais.

Qualquer intervençăo em fragmentos florestais, especialmente em Unidades de Conservaçăo, deve levar em conta, em primeiro lugar, os conflitos existentes com relação à demanda humana sobre a natureza, que não devem ser relegados no estabelecimento de uma politica global de ocupação de espaço. objetivando o relacionamento homem e natureza, segundo GUILLAUMON (1986), O estudo das funçóes do ambiente natural é indispensável para uma tomada de decisão mais consciente no estabelecimento dos usos dos espaços.

E' necessario ter em mente que uma utilização intensa, mesmo com recreação e lazer, pode muitas vezes estar em conflito com a função biológica, ou mesmo social e económica que este espaço devera desempenhar. Isto está diretamente ligado à capacidade de suporte ("carny capacity"). A gestão das regióes naturais depende por um lado, de suas caracteristicas proprias, de sua capacidade de acolhimento, de sua capacidade de evolução e, de outra parte, do desenvolvimento desejado.

SILVA (1992a) ressalta que o Plano Diretor náo deve ser estático, devendo ser revisto periodicamente, após entendimentos entre a equipe técnica responsável, diante do surgimento de fatos novos, tais como novas tecnologias, alterações econômicas, politicas e sociais. 


\subsection{Estudos de casos:}

Para melhor compreensão dos processos de planejamento envolvidos nos programas de instalaçăo e desenvolvimento das Unidades de Conservação, foram estudados e analisados alguns Planos de Manejo existentes no Brasil, apresentados a seguir.

Muitos deles foram elaborados em 1981, quando 0 Ministério da Agricultura, através do convênio IBDF (Instituto Brasileiro de Desenvolvimento Florestal) e FBCN (Fundaçăo Brasileira para Conservação da Natureza), nomeou várias equipes técnicas para elaboração de Planos de Manejo de Unidades de Conservaçăo.

O Plano Diretor da Reserva de Poços das Antas-RJ (IBDF, 1981a) tinha o principal objetivo de proteger a área, com 5,000 ha., onde vive 0 mico-leão dourado. O Plano Diretor para o Parque Nacional do Parque do Iguaçu, no extremo-oeste do Estado do Paraná objetivava resguardar aquele local, que tem cerca de 170.000 ha. e abriga as quedas do Iguaçu, uma das primeiras maravilhas naturais do continente (IBDF, 1981b).

Foi efetuado tambem o Plano Diretor do Parque Nacional do Araguaia, onde está a liha do Bananal, a maior ilha fluvial quaternaria do mundo, situada a noroeste de Goiás. O parque, com área de 562.321 ha., representa uma mostra expressiva da regiảo situada entre a Provincia do Cerrado e o domínio Amazónico, constituindo-se uma área rica em espécies da flora e da fauna, caracteristica comum à areas de transiçăo (IBDF, 1981c).

O Plano Diretor da Reserva Biologica de Sooretama, "a terra dos animais da mata", (IBDF, 1981d) visava proteger esta área, localizada entre os municipios de Linhares e Săo Mateus, ao norte do Espirito Santo, com 24 mil ha. Ela se constitui em um testemunho vivo do ecossistema da chamada "floresta dos tabuleiros", guardando preciosos exemplares de madeira de lei, outrora muito abundantes na região. 
Nesta epoca foi tambem feito o Plano Diretor do Parque Nacional da Serra da Canastra (sudeste de Minas Gerais). Este parque, com 71.525 ha., abriga as nascentes principais do Rio Såo Francisco e algumas que contribuem para a Bacia do Paraná, situando-se o parque no divisor de aguas destas duas bacias. Um dos destaques do local é a cachoeira Cascata D'Anta, de grande beleza cênica (IBDF, 1981e).

Foi ainda elaborado o Plano Diretor do Parque Nacional de Caparao, situado na regiăo sudoeste do Espirito Santo, abrangendo parte de Minas Gerais. Este parque, com 26.000 ha, abriga o Pico da Bandeira, com $2.890 \mathrm{~m}$, considerado, até 1964 , o ponto culminante do Brasil, constituindo-se um elemento histórico e cultural de grande interesse nacional (IBDF, 1981f).

- Parque Nacional da Tijuca (Rio de Janeiro), com aproximadamente 3.300 hectares, que representa uma amostra da floresta pluvial tropical, hoje em regeneraçáo, também ganhou o seu Plano Diretor (IBDF, 1981g). Pelos seus atributos naturais de grande beleza e por estar localizado dentro de uma regiăo metropolitana, ele representa mais uma opçăo de lazer para a populaçăo da cidade e uma importante atraçăo turistica.

O Plano Diretor do Parque Nacional de Ubajara, situado a noroeste do Ceará sugeriu a mudança de categoria desta Unidade de Conservaçăo de Parque Nacional para Monumento Natural, devido principalmente ao seu pequeno tamanho. Esta unidade, com 563 ha., abriga várias grutas e protege uma pequena mostra de serra úmida e regiāo semi-árida (IBDF, 1981h).

No Estado de Săo Paulo, o trabalho de planificaçăo dos parques sob jurisdiçăo do governo estadual, teve um grande impulso com a participaçăo de especialistas estrangeiros no desenvolvimento de vários Planos de Manejo. Desta forma, SEIBERT et alii (1975) desenvolveram o do Parque Estadual de Campos de Jordăo, localizado ao Nordeste do Estado. Neste trabalho, adotou-se uma metodologia paisagistica, cujo planejamento obedeceu a uma sucessão de etapas, que partindo de consideraçóes sobre as bases 
naturais e as bases sócio-econômicas, realiza a diagnose da paisagem e partindo daí, chega ao planejamento propriamente dito, ao que se segue o desenvolvimento do plano, ou seja a fase de execução.

Nesse contexto, NEGREIROS et alii (SÃO PAULO, SECRETARIA DA AGRICULTURA, 1984) elaboraram o para o Parque Estadual da llha do Cardoso, nas proximidades de Cananeia, litoral sul do Estado de São Paulo. O documento, de natureza conceitual, deveria ser detalhado em etapas posteriores, e procurou enfocar a área do Parque dentro do contexto regional, prevendo o desenvolvimento no trecho litoraneo situado entre Santos e Peruibe e 0 consequente afluxo de turistas.

Outro plano conceitual foi desenvolvido por BERTONI et alii (1986) para o Parque Estadual de Vassununga, para estabelecer diretrizes básicas de sua efetiva proteção, propiciando sua utilização em atividades recreativas, educacionais e cientificas. Para os autores, a area, localizada, no municipio de Santa Rita do Passa Quatro, com seus 832 hectares, representa uma das últimas áreas remanescentes da Floresta Latifoliada Tropical Semidecidua, em latossolo roxo, na região de Ribeirăo Preto. Nesse local, à semelhança da Estação Ecológica de lbicatu, existem exemplares milenares de jequitibá rosa - Cariniana legalis (Mart.) O.Ktze.

Mais recentemente, GUILLAUMON et alii (SÃO PAULO, SECRETARIA DO MEIO AMBIENTE, 1989) elaboraram o do Parque Estadual da llha Anchieta, que consiste no planejamento de uso do solo daquela Unidade de Conservação, situada no litoral norte do Estado de Săo Paulo, com area de 828 hectares. $O$ documento, através do zoneamento da área, estabeleceu as diretrizes basicas para o seu manejo, tendo como meta a consenvaçăo dos seus recursos naturais e o seu uso: lazer voltado para a Educação Ambiental.

No Estado do Mato Grosso do Sul, ALMEIDA et alii (1990) desenvolveram o para a Reserva Ecologica do Parque dos Poderes, cuja denominação deveria ser alterada, conforme sugestão do documento, para Parque Estadual do Prosa. Com cerca de 120 hectares, a importancia desta unidade se deve à sua privilegiada localização, no perímetro urbano de Campo 
Grande. De acordo com os autores, esta unidade, alem de fornecer amostras de rormacoes vegetais do cerrado e mata ciliar, podera desempenhar importante função com o desenvolvimento de programas de Educação Ambiental e interpretação da natureza.

Constatou-se também a existéncia de Planos de Manejo para Unidades de Consevvaçâo particulares. ALMEIDA et alli (1990) elaboraram o para a Resena Particular Natural do Morro da Vargem, com aproximadamente 100 hectares e pertencente a comunicade budista Soto Zen Shu, no municipio de Ibiracu (Espirto Santo, que abriga vestigios da Mata Atlantica. 0 plano objetiva promover significativos avancos na conscientizaçăo conservacionista das comunidades regionais.

\subsection{Aspectos da Educação Ambienta!:}

Segundo a FBCN - Fundação Brasileira para a Conservação da Natureza (1972), o despertar de consciencia em prol de melhor padrão educacional, que mostre a interdependencia de tudo na natureza, que dê destaque as leis ecologicas, que assegure prioridade aos valores reais e que busque a plenitude da vida em ambiente da mais alta qualidade, fez sentir a urgente necessidade de se implantar o que se passou a chamar de educação ambiental Para uns, ela é mais do que uma educação ecológica; para outros e uma educação conservacionista ampliada; para terceiros ainda, transcende o conjunto das preocupacôes antipoluiçâo. $E^{\prime}$, em suma, uma educação que une as pessoes, os povos e as naçôes com vistas ao bem estar geral.

A UNESCO, citacia por SORRENTINO et alli (1990) diz que a Educação Ambiental deve "propiciar a tomada de consciencia generalizada a respeito das causas e conseqüencias que têm para o homem, para a sociedade e para a comunidade internacional, os problemas do meio ambiente $e$ estimular na vida diaria, profissional e na ação para 0 desenvolvimento, uma ética, atitudes e condutas individuais e coletivas que contribuam a protecáo e ao melhoramento do meio ambiente". 
Segundo a FEEMA - Fundaçăo Estadual de Engenharia de Meio Ambiente (1990), a Educaçăo Ambiental é o "processo de aprendizado e comunicação de questóes relacionadas a interação dos homens com seu ambiente natural. $E^{\prime} \circ$ instrumento de formação de uma consciéncia através do conhecimento e da reflexăo sobre a realidade ambiental".

O desenvolvimento de práticas de Educaçấo Ambiental destaca-se como uma estratégia para a reversăo do processo de degradaçăo e para a conservaçăo e utilizaçăo racional dos recursos naturais. $E^{\prime}$ assim que na Conferencia da ONU, realizada em 1977, em Tbilisi, aponta-se como objetivo fundamental da Educação Ambiental: "Fazer com que os individuos e as coletividades compreendam a natureza complexa do meio ambiente natural e do criado pelo homem, resultante da interaçåo de seus aspectos biológicos, fisicos, sociais, económicos e culturais, e adquiram os conhecimentos, os valores, os comportamentos e as habilidades práticas para participar responsável e eficazmente na preservaçăo e na soluçăo dos problemas ambientais e na questáo da qualidade do meio ambiente (Secretaria de Estado do Meio Ambiente de Såo Paulo, 1991).

Para DUTRA \& HERCULIANI ( 1990) dentro do programa de uso público, o sub-programa de interpretação da natureza e uma ferrramenta indispensável para o manejo da Unidade de Conservaçăo, pois estabelece um ponto de conexăo entre o visitante e a administraçăo, a fim de despertar nos primeiros a receptividade pela conservaçăo da area, bem como transmitir-lhes a idéia da importáncia da mesma.

Segundo ENCALADA (s/d), a Educaçăo Ambiental deve dirigir-se a criaçăo de consciencia sobre as relaçóes estabelecidas entre o homem e a natureza e os problemas derivados destas relaçoes, os quais ameaçam a sobrevivencia da vida biológica em geral e da vida social. $E$, finalmente, deve promover a busca da soluçăo a estes problemas em todos os âmbitos. 
Segundo SILVA (1992a), a Educação Ambiental é entendida enquanto pratica social transformadora da sociedade, tendo como preocupação central o seu património natural e cultural. Essa visão possibilita avançar na construção de uma relação com a natureza, ultrapassando a posse e seu uso pragmático e indiscriminado, para uma relação mais profunda, em que o homem se perceba como elemento integrante e dependente dela.

Para CASTILLO et alii (s/d) no ámbito da conservação da natureza e das areas naturais protegidas, define-se Educação Ambiental, em geral, como um processo dirigido a todos os niveis que, através de diferentes meios, pretende alcançar a tomada de consciência, o desenvolvimento de valores, de atitudes e de técnicas com a finalidade de contribuir para a soluçăo de problemas ambientais.

Segundo SILVA, (1992a) a educação sobre o meio ambiente deve constar em quase todas as categorias de manejo de Unidades de Conservação, uma vez que as mesmas se constituem em laboratório natural para este tipo de atividade. Este autor ressalta que a Educaçåo Ambiental envolve desde a cooperação de escolas, universidades, até outras organizaçōes para promover a conscientização sobre o meio ambiente, dentro e fora dos parques e reservas. Uma atenção especial deve ser dada neste sentido aquelas unidades localizadas próximas dos grandes centros populacionais, em função da larga demanda pelas mesmas.

Para CRESTANA et alii (1993), a Educação Ambiental passa a ser, dessa forma, um processo de interação entre os individuos em busca da conscientizaçáo, frente à necessidade da participaçăo da sociedade na resoluçăo de problemas ecológicos que nos cercam, assim como na proteçăo e conservação do nosso património natural para as gerações presentes e futuras. 
MACFARLAND (1982) elaborou um esquema da metodologia para a preparação de Planos de Interpretaçăo e Educação Ambiental de Áreas Silvestres, constando das seguintes etapas básicas:

a) Eleger os objetivos provisórios, baseando-se no levantamento da área e nos conhecimentos já existentes da equipe de planejamento sobre a área;

b) Análise e sintese dos antecedentes e informaçóes básicas incluindo os recursos e caracteristicas da Unidade de Conservação e seu entorno; uso atual e potencial da Unidade e regiâo para os visitantes; programas e componentes atuais e projetados para interpretação e Educação Ambiental para a Unidade e regiâo;

c) Elaborar os objetivos definitivos do Plano, considerando suas limitaçőes e aptidóes ;

d) Preparar os programas especificos e em seguida o Plano integral de Desenvolvimento;

e) Apresentar, discutir e revisar o plano, com instituições governamentais e nãogovernamentais, em nivel local, regional e nacional;

f) Publicar, distribuir e implementar o Plano, efetuando as revisões necessárias ao longo do tempo.

Segundo ALMEIDA et alii (1991), a Educaçăo Ambiental não visa somente a aquisiçăo de conhecimento sobre o ambiente, mas à mudança de comportamento, à determinação para a ação e a busca de soluções para os problemas. Para estes autores, os objetivos da Educação Ambiental devem adaptar-se a realidade económica, social, cultural e ecológica de cada sociedade e cada regiấ. Esses objetivos devem ajudar o individuo a tomar consciência do ambiente global, facilitar a interpretação dos elementos que constituem todo o meio e desenvolver no individuo valores sociais e sentimentos de interesse pelo ambiente. 
Segundo MOORE (1987), talvez o fator que mais dificulte o trabaiho dentro de Unidades de Conservaçâo seja o fator humano, quer dizer, 0 trato com os visitantes e os moradores da região de entorno. Pode-se dizer que o manejo dos recursos é $80 \%$ do público e $20 \%$ dos recursos mesmo. Para estes autores, um programa de interpretação desenvolvido em harmonia com 0 manojo da área, por uma equipe devidamente treinada, sera muito mais efetivo para a proteção da mesma do que um intenso programa de fiscalização.

Tambem preocupado com os habitantes vizinhos de uma Unidade de Conservaçá, CAPOBIÁNCO (1990) assinala que o processo inicial do programa de Educação Ámbientai necessita, portanto de uma profunda identidade entre os agentes e os moradores. E' o momento onde se torna clara a necessidade do diálogo franco que caracteriza a comunicação educativa que, na concepção de Paulo Freire, centra-se nos problemas reais do indivíduo e seu mundo circundante, com o qual tem uma experiéncia vivida.

A este respeito, SORRENTINO et alii (1990) enfatizam que os projetos na area de Educação Ambiental, quando baseados numa proposta ampla, devem prever um esforço contínuo, uma vez que se trata de um processo interativo educador-educando e cujos resultados se manifestam a médio ou longo prazo pelo próprio caráter do processo educativo.

Finaimente, AMARAL \& ROCHA (1987) assinalam que as Unidades de Conservação brasileiras não cumprem as finalidades conservacionistas e educativas, previstas na legislação e internacionalmente reconhecidas. Nos Parques Nacionais e em outras Unidades de Conservaçăo, onde o uso cireto pelo público e permitido, um crescente afluxo de visitantes, sem os indispensáveis programas educativos $\theta$ de orientação à visitação, promovem intensa degradação dos recursos naturais, que são a principal razão da existência das Unidades de Conservação. Os organismos responsáveis pela sua administraçăo não dispõem de recursos financeiros e humanos necessários ao cumprimento das responsabilidades a eles atribuidas. Por isso, estes autores propóem a mobilização voluntária da sociedade brasileira para suprir as suas deficièncias. 


\section{MATERIAL E MÉTODOS:}

\subsection{Localização geográfica da área:}

- Situação: A Estação Ecológica de lbicatu situa-se no Bairro da Floresta, setor oeste do municipio de Piracicaba, localizado na regiâo central do Estado de Săo Paulo, entre as coordenadas $22^{\circ} 47-22^{\circ} 48^{\prime}$ - Latitude Sul e $47^{\circ} 49^{\prime}-47^{\circ} 50^{\prime}$ - Longitude Oeste, conforme pode ser verificado nas figuras a seguir. Ela e composta por uma gleba contínua, contida num poligono irregular, que delimita uma superficie de 76,40 ha.

- Limites: A Estaçăo Ecológica de lbicatu e envolvida quase totalmente pelas terras de propriedade da família Moraes Barros. No setor leste confronta com a propriedade do $\mathrm{Sr}$. Waldemar Gimenes.

- Acessos: Os principais acessos a área sảo efetuados pela Rodovia Piracicaba-Anhembi (SP-147), atualmente em fase de pavimentaçăo, a partir do Bairro Pau D'Alho e pela estrada vicinal (asfaltada) Luiz Dias Gonzaga (PI040), a partir do Bairro Monte Branco. A área de Ibicatu situa-se precisamente a sete quilometros por estrada de terra, do km 23 da Rodovia Estadual (SP-147), 
Figura 1 -

LOCALIZAÇÃO DA ESTAÇÃO ECOLÓGICA DE IBICATU NO CONTEXTO NACIONAL E ESTADUAL

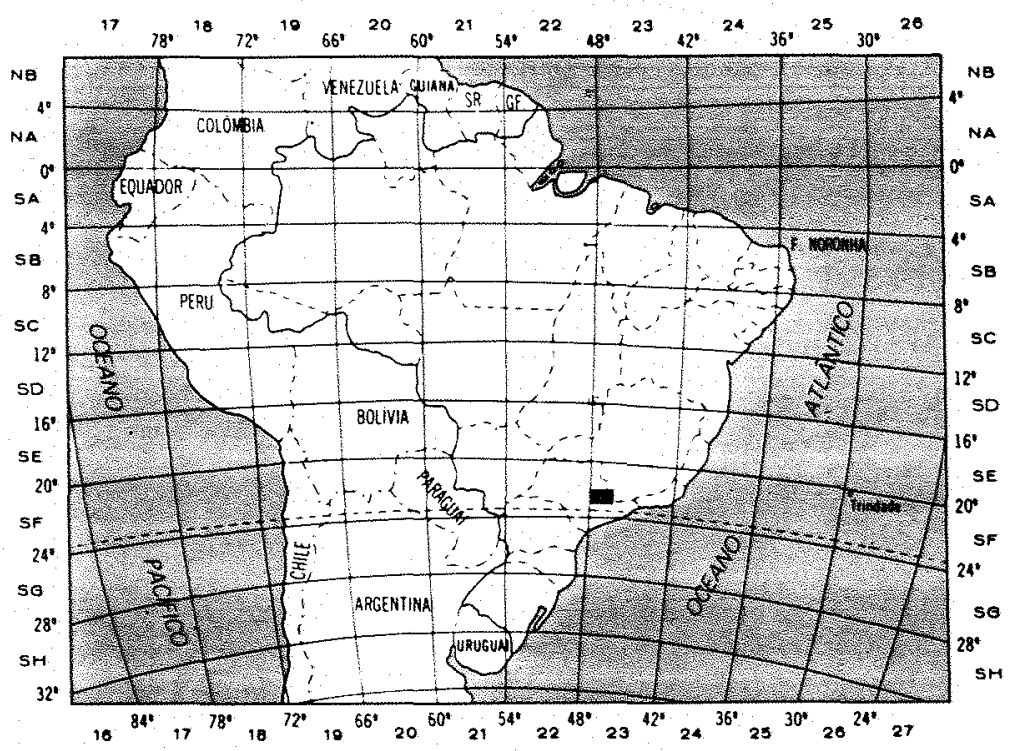

BRASIL

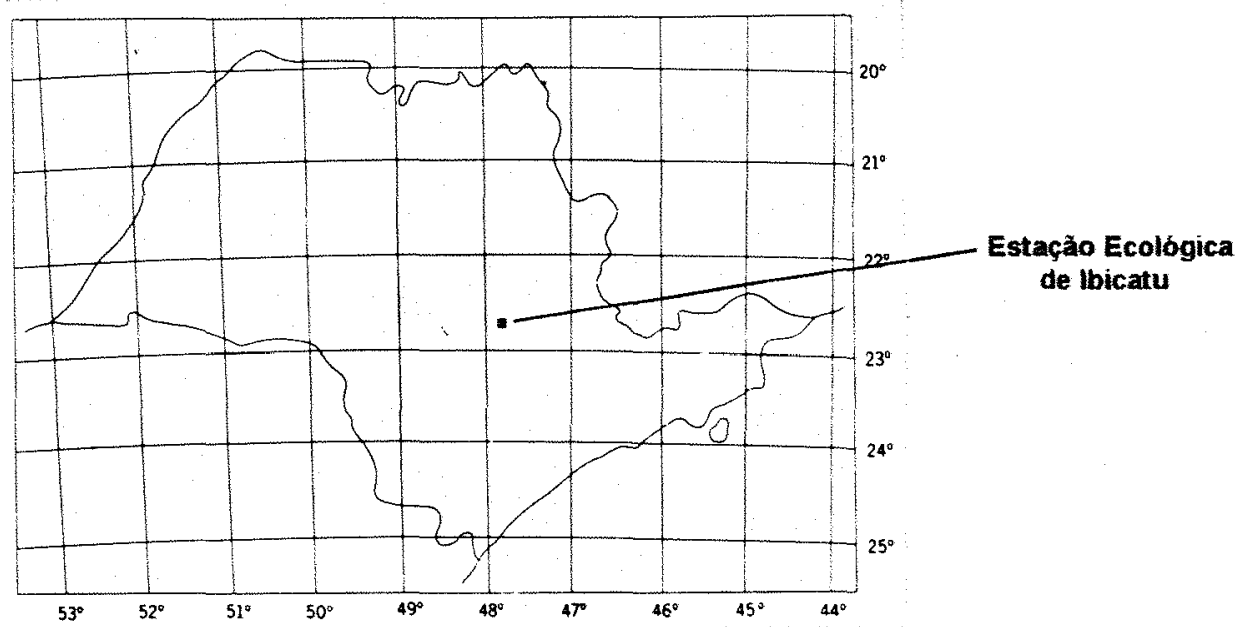

ESTADO DE SÃO PAULO

BASE CARTOGRÁFICA: IBGE/TERRAFOTO SIA. 


\section{Figura -2 ESTAÇAO ECOLOGICA DE IBICATU: PRINCIPAIS VIAS DE ACESSO}

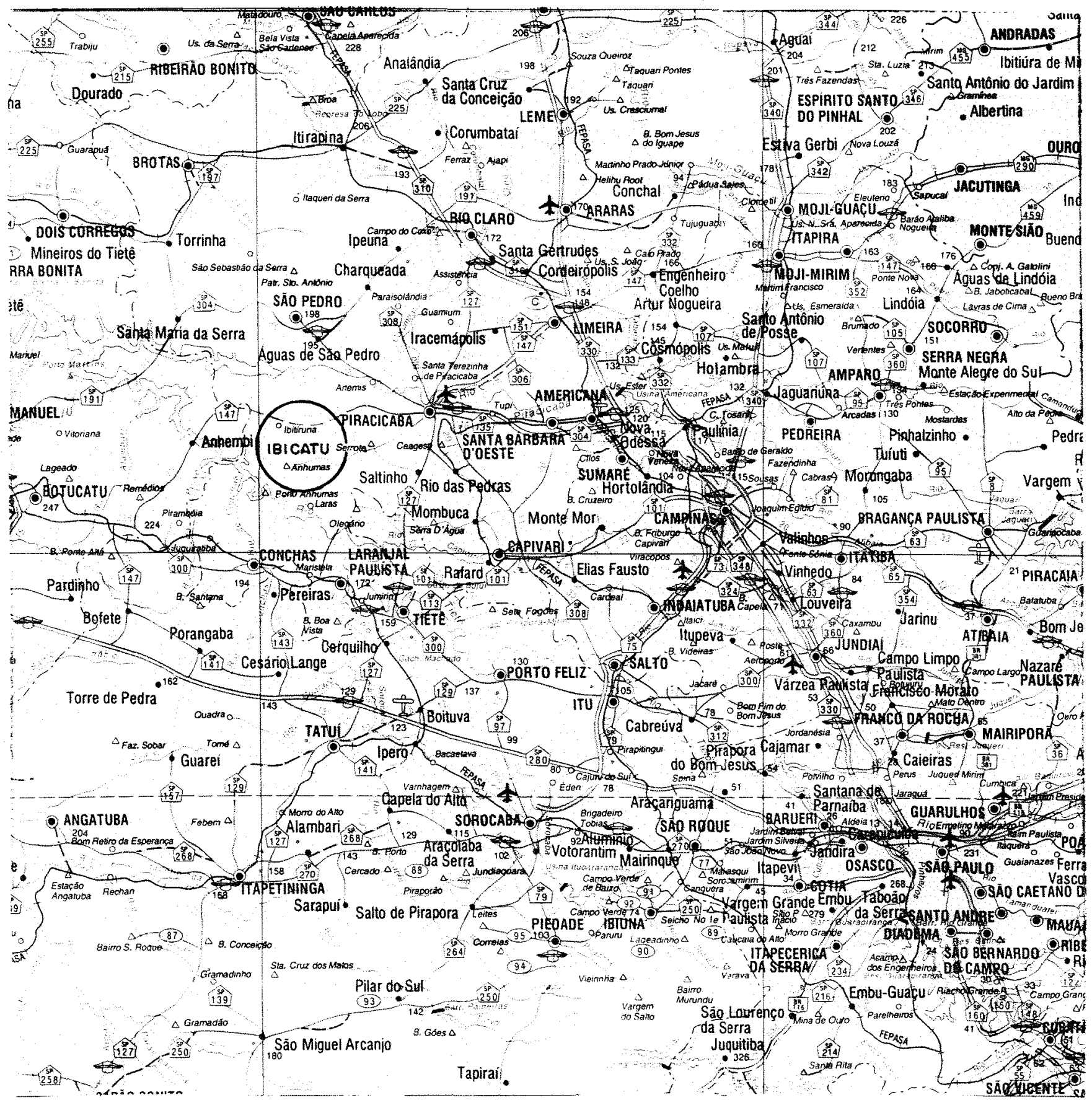


Figura 2 - (continuação)

\section{Convençōes:}

SEDES URBANAS

O. SEDE DE COMARCA

- Sede de Municíplo

- SEDE DE DISTATTO

$\Delta \quad$ Vilas, Bairos, Usinas do Alcool, Patrimonios

RODOVIAS

Federais, Estaduais e

Municipais Pavimentadas

- $=$ Pista Simples e Dupla

- $===$ Em Construçáo e Pavimentaçăo

Não Pavimentadas

(4B)- (C) Vicinais conservadas pelo DER

REFERÊNCIAS EM QUILOMÉTROS

100 is Quilómetro em Rod. Radial e Transversal

+517. Distância entre Locais

- Divisa das Regionais do DER

$\rightarrow$ Posto de Policiamento Rodoviário Estadual

FERROVIAS

- FEPASA R.F.F.S.A.

HIDROGRAFIA

$\longrightarrow$ Rio, Ribeirăo, Córrego

Deservatorio Existente

Reservalório en Construçăa

Travessia por Balsa

1 - Barragens e Portos

AEROPORTOS

* $\vec{\sharp}$ Pista Pavimentada e náo Pavimentada

\section{Escala:}

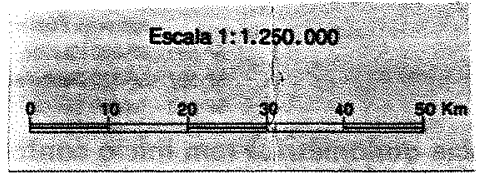


Figura - 3

LOCALIZAÇAO DA ESTAÇAO ECOLÓOICA DE IBICATU NO CONTEXTO RECIONAL

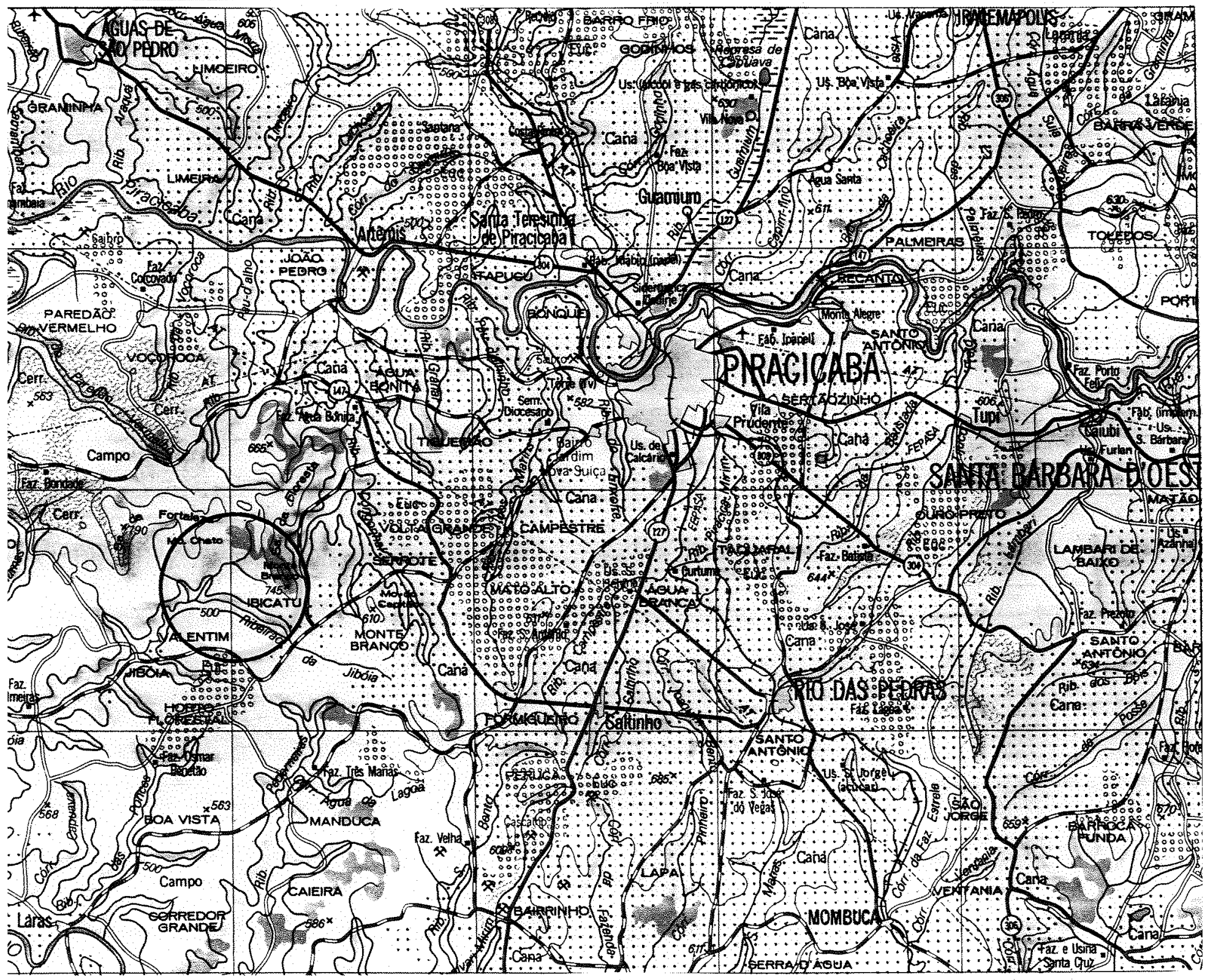

\section{BASE CARTOORÁFICA IBGE - ESCALA: 1:230.000}

FOLHA SF-23-Y-A MI -2737/3 - 1993 


\section{(Continuação) - Figura 3}

\section{Legenda:}

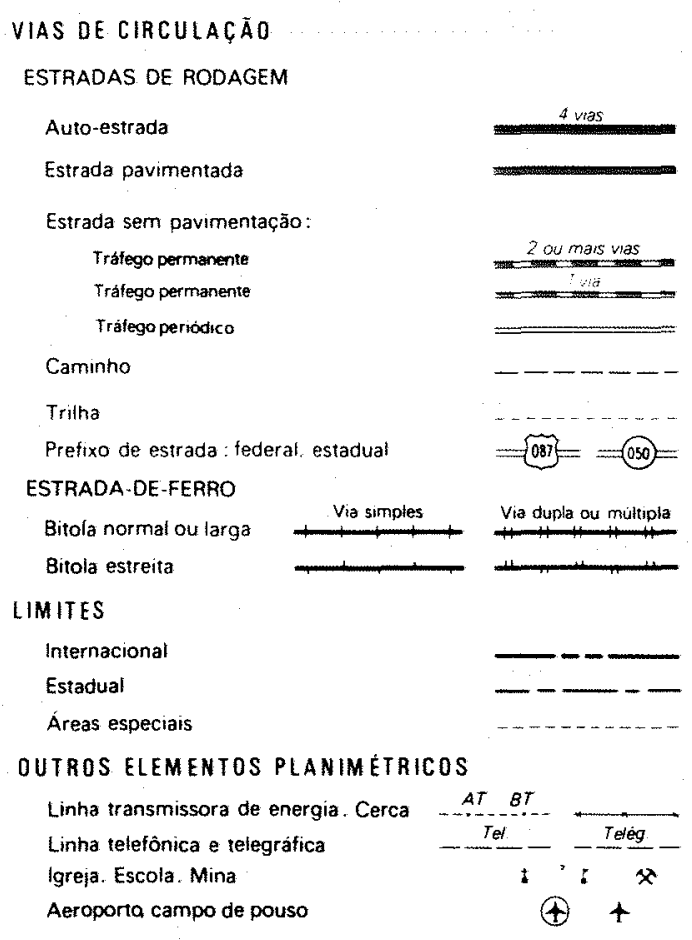

ELEMENTOS ALTIMETRICOS

Ponto trigonométrico. Ponto astronỏmico

Ponto de satélite

Cota Comprovada. Cota não comprovada

Cota não comprovada (ponto identificável)

Cota mais elevada da compilaçăo

Superfície deformada. Areia

ELEMENTOS DE VEGETAÇAO

Mata, floresta. Cerrado, macega, caatinga

Culturas: permanente, temporária

Mangue Salina

Arrozal : terreno seco. úmido

ELEMENTOS DE HIOROGRAFIA

Curso d'água intermitente

Lago ou Lagoa intermitente

Terreno sujeito a inundação

Brejo ou pântano

Poço (água). Nascente

Rápidos e cataratas grandes

Rápidos e cataratas

Rocha submersa e a descoberto

Molne e represa : alvenaria e terra

Ancoradouro Rio seco ou de aluvião

Recife rochoso

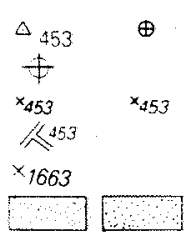

$\because$ aper

iisis: $\because \because 9$

$\because 7$
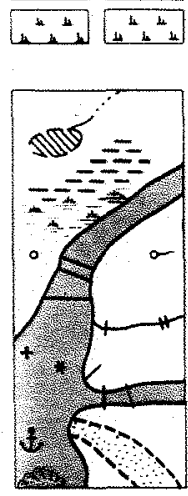

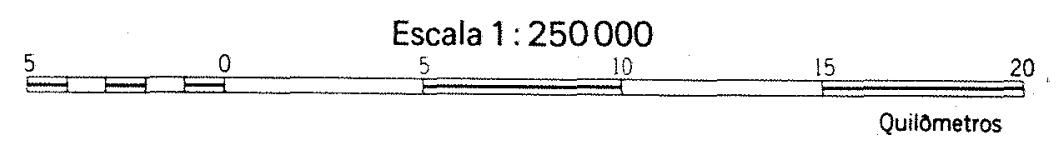

Escala de Declividade

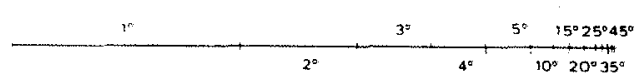

EQUUIDISTANNCIA DAS CURVAS DE NIVEL : 100 METROS

AS CURVAS MESTRAS ESTAO REPRESENTADAS EM UINHA GROSSA CONTINUA E CORRESPONOEM A CADA 5 a CURVA DE NIVEL
DECLINAÇÃO MAGNÉTICA EM- 1993

E CONVERGÉNCIA MERIDIANA

DO CENTRO DA FOLHA

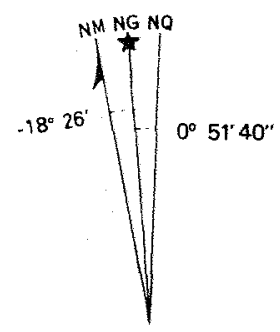




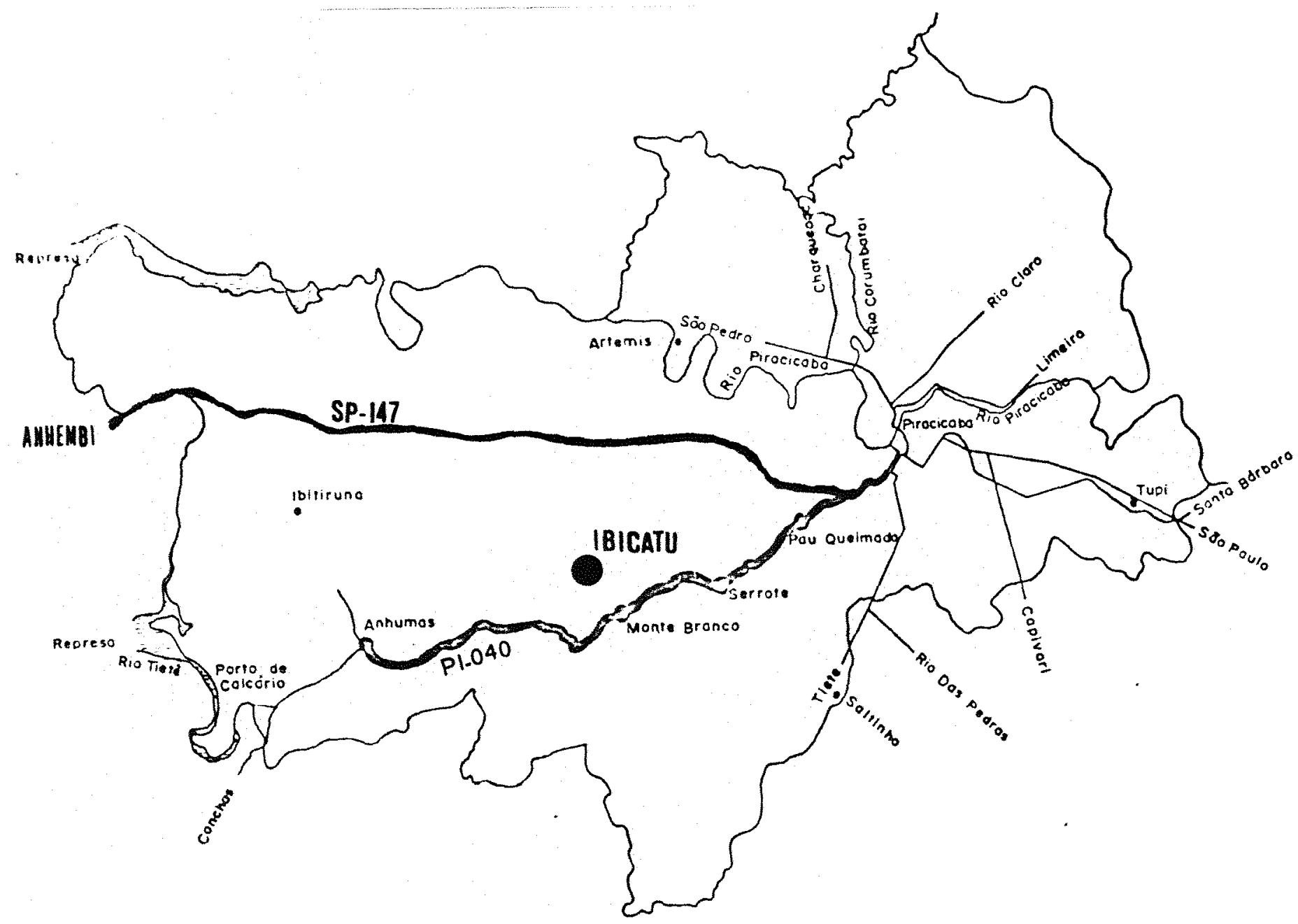


Figura 5 - ESTAÇÃO ECOLÓGICA DE IBICATU: LOCALIZAÇÃO Coordenadas - $22^{\circ} 47^{\prime}-22^{\circ} 48^{\prime}$ - Latitude Sul

$47^{\circ} 49^{\prime}-47^{\circ} 50^{\prime}$ - Longitude Oeste

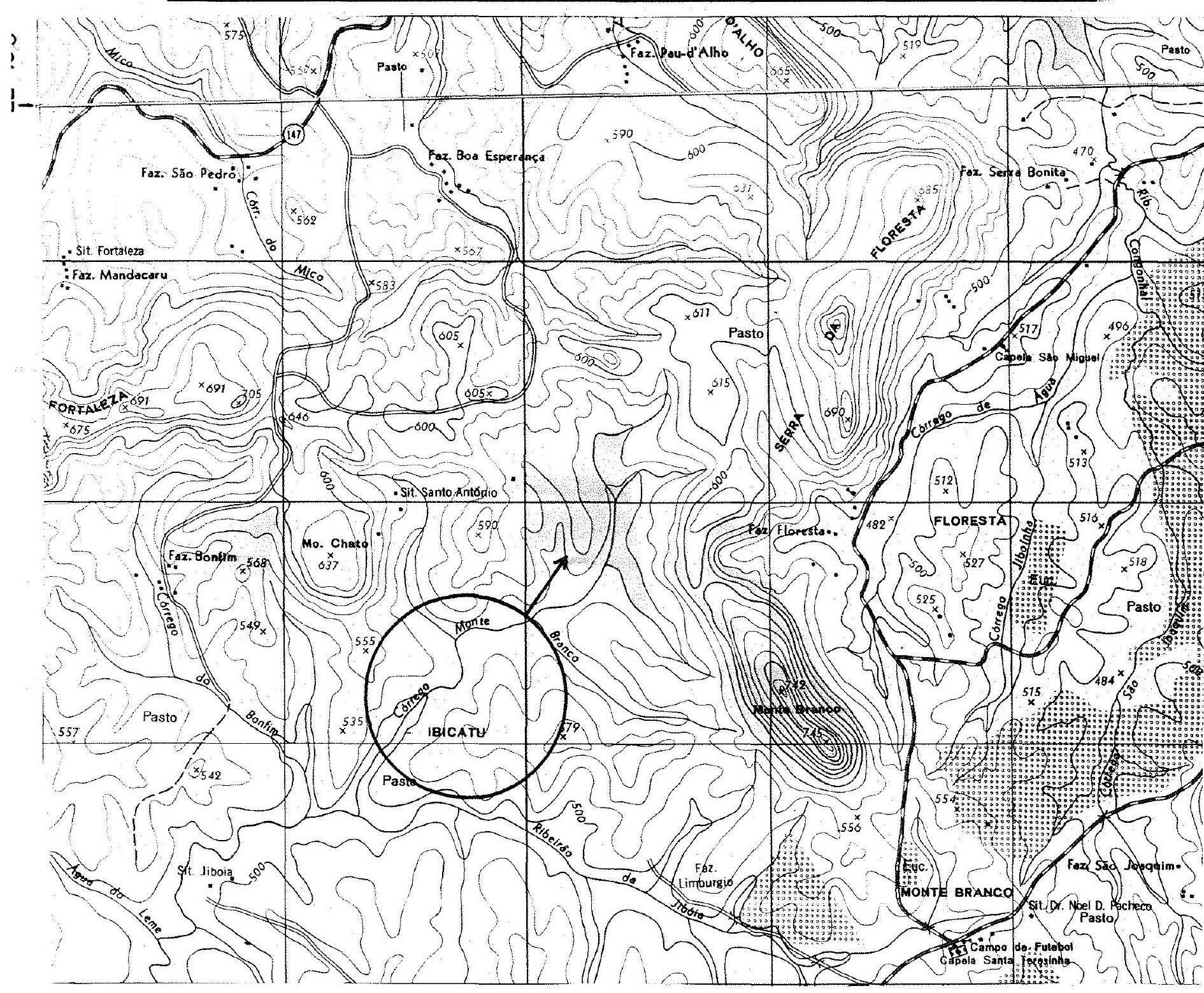




\section{(Continuação) - Figura 5}

\section{LEGENDA :}

\section{LOCALIDADES}

Mais de 100000 habitantes

De 50000 a 100000 habitantes

De 20000 : 50000 habitantes

De 5000 a 20000 habitantes

Até 5000 habitantes

Vila

Povoado

Núcleo ou oroprledade rural

LIMITES

Internacional
Interestadual
Intermuniclpal
Arcas especials

HIDROGRAFIA

Mangue, Salina

Curso d'água intermitente

Lago ou lagoa intermitente

Terreno sujelto a inundação

Brejo ou pántano

Poco (Ggua). Nascente

Salto, cascate ou catarate

Cachoeire

Corredelra, rápldo, travessăo

Barragens: tersa, alvenaria

Fundeadouro

Arela

Campo de emergencia. Farol

Igreja. Escola. Mina

VEGETACÁO
CIDADE CIDADE CIDADE

CIDADE

CIDADE

Vila

Povoado

Núcleo
ESTRADAS DE RODAGEM

Auto-estrada
Pavimentada
Sem pavimentaçăo
Caminho. Trilha
Identificação de rodovias
ESTRADAS DE FERRO
Bitola normal ou larga
Bitola estreita
Caminho aéreo (cabo)
Linha de bonde
Linha telefônica e telegráfica
Linha de energla elétrica

Altitudes:
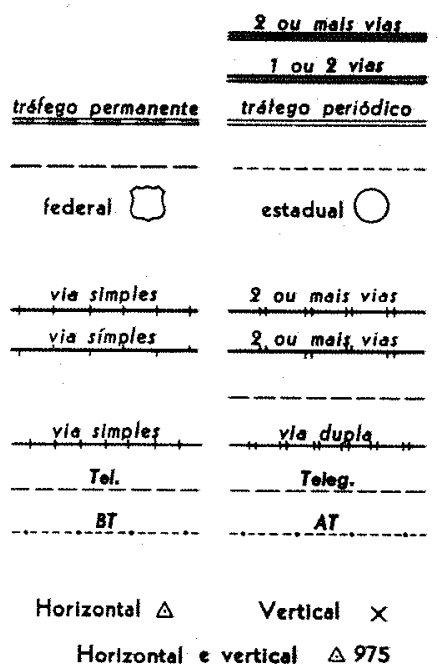

Comprovada $\times 792$ Nao comprovada $\times 792$

Mata, floresta. Cerrado, macega, caatinga.

Culturas: permanente, tempordrio

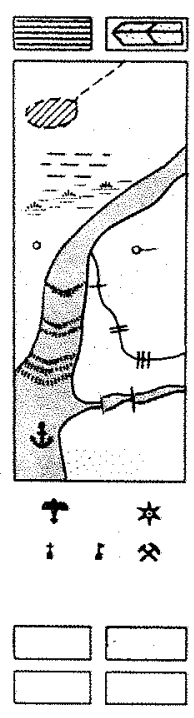

DECLINACAOO MAGNETICA 1969 E CONVERGENCIA MERIDIANA DO CENTRO DA FOLHA

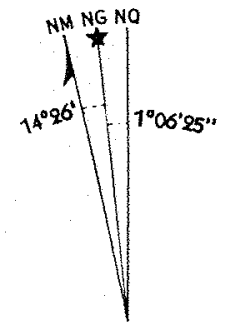

ESCALA 1:50000

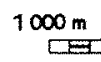

$1000 \mathrm{~m}$

0 1000 2000 Eqüldistância das curvas de nivel 20 metros 
(Continuação) - Figura 5

\section{LEGENDA :}

VIAS DE CIRCULAÇÃO
ESTRADAS DE RODAGEM
Auto-estrada
Estrada pavimentada
Estrada sem pavimentação
Estrada sem pavimentaçăo
Caminho
Trilha
Prefixo de estrada : federal, estadual
ESTRADA DE FERRO
Bitola larga
Bitola estreita
LIMITES
Internacional
Estadual
Intermunicipal
Áreas especiais
OU TROS ELEM EN TOS PLA NIM ÉTRIC OS
Linha transmissora de energia. Cerca
Linha telefónica e telegráfica.
Igreja. Escola. Mina
Moinho de Vento. Moinho de água
Campo de emergência. Farol

\section{ELEMENTOS ALTIMÉTRICOS}

Ponto trigonométrico. Referência de nivel

Ponto astronómico. Ponto barométrico

Cota comprovada. Cota não comprovada

Superficie deformada. Areia

ELEMENTOS DE VEGETAÇÃO

Mata, floresta. Cerrado, macega, caatinga

Culturas: permanente, temporária

Mangue. Salina

Arrozal : terreno seco, úmido

ELEMENTOS DE HIDROGRAFIA

Curso d'água intermitente

Lago ou lagoa intermitente

Terreno sujeito a inundação

Brejo ou pântano

Poço (água). Nascente

Rápidos e cataratas grandes

Rápidos e cataratas

Rocha submersa e a descoberto

Molhe e represa : alvenaria e terra

Ancoradouro. Rio seco ou de aluvião

Recife rochoso
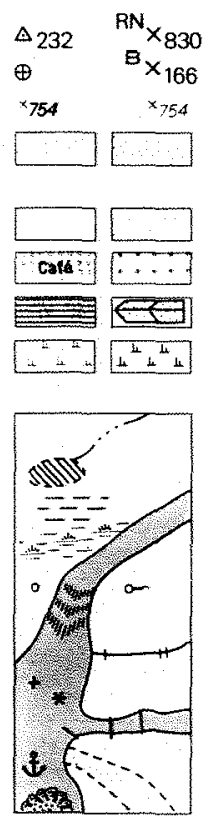

DECLINAÇÃO MAGNÉTICA EM

ARTICULACÃO DA FOLHA

\begin{tabular}{|c|c|c|}
\hline $\begin{array}{c}\text { SANIA WARA } \\
\text { DA SERRA } \\
\text { WH-2735-2 }\end{array}$ & $\begin{array}{l}\text { SAO FEDRO } \\
\text { MI-2736-1 }\end{array}$ & $\begin{array}{l}\text { PIRACICABA } \\
\text { พ1.2736-2 }\end{array}$ \\
\hline $\begin{array}{l}\text { ANHESBA } \\
\text { M.-2735-4 }\end{array}$ & $\begin{array}{l}\text { LARAS } \\
M-2736-3\end{array}$ & $\begin{array}{l}\text { CAPYYAR } \\
\text { WI: } 2736-4\end{array}$ \\
\hline $\begin{array}{l}\text { CONCHAS } \\
\text { M-2764.2 }\end{array}$ & $\begin{array}{l}\text { LARAMUAL } \\
\text { PAULISTA } \\
\text { M1-2265-1 }\end{array}$ & $\begin{array}{c}\text { P010 FELZ } \\
\text { M-2765.2 }\end{array}$ \\
\hline
\end{tabular}

Escala 1:50000

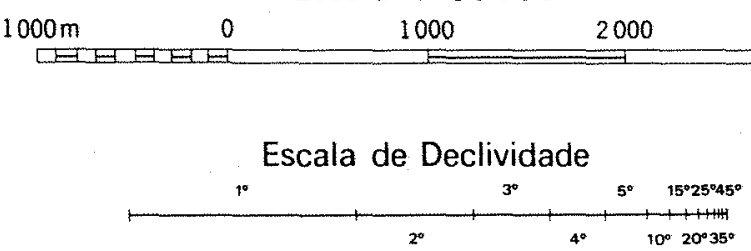

EQÜIDISTÂNCIA DAS CURVAS DE NIVEL : 20 METROS
1983

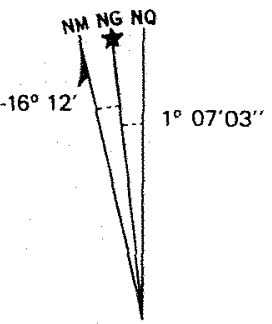

\section{Observaçăo: Situaçăo acima da Latitude 22\%45's}




\section{Figura 6 - ESTAÇÃO ECOLOGICA DE IBICATU: PLANTA TOPOGRAFICA} Área: 76,40 ha.

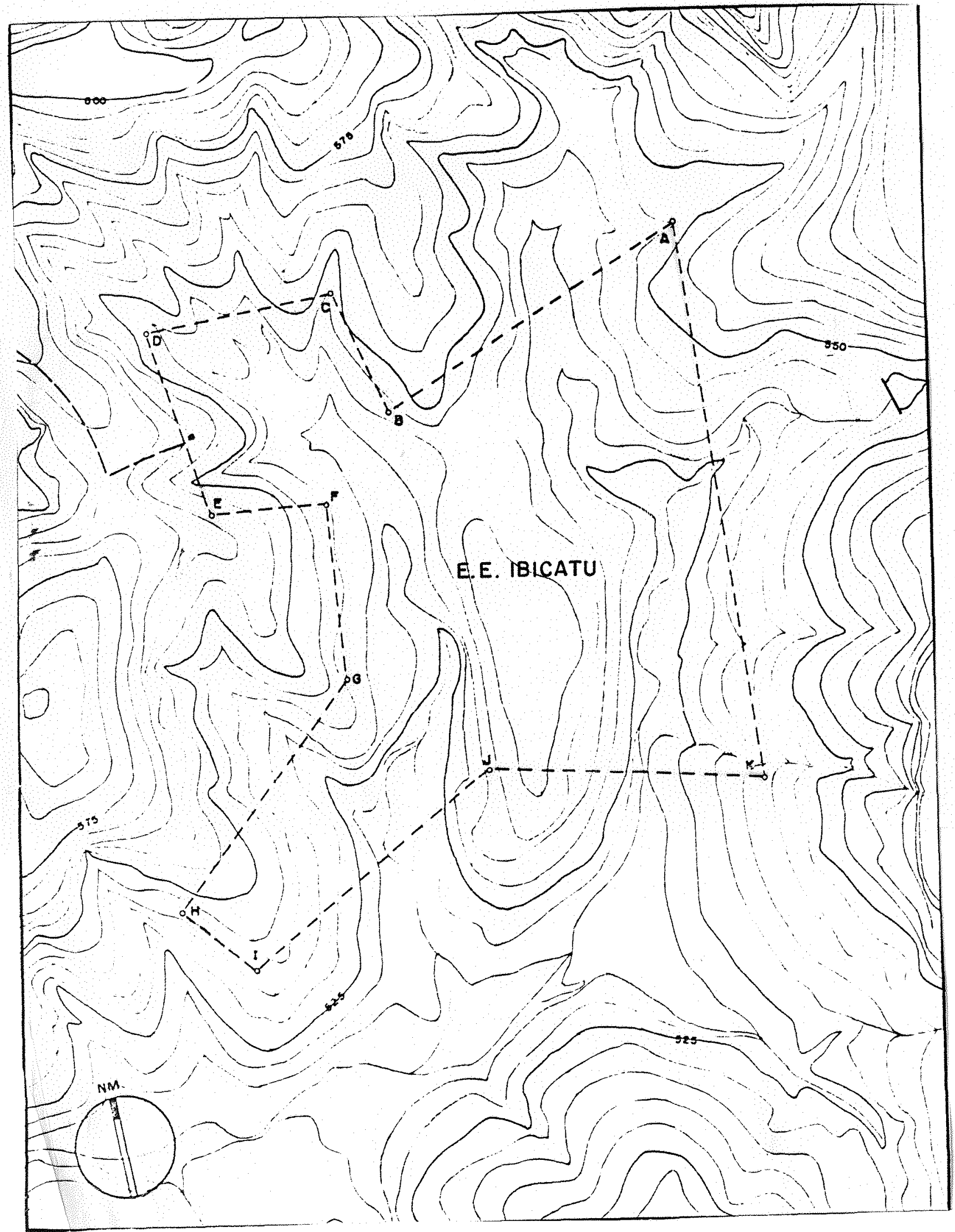

\section{BASES CARTOGRAFICAS:}

PLANTA ST. 565 - D.E.M.A. (Secretaria de Agricultura-SP, 1958). Escala: 1: 2500

PLANO CARTOGRAFICO DO EST. DE SAO PAULO-FOLHA: SF-23-Y_AN-3-NE-A. EsC.: 1: 10.000 


\subsection{Aspectos históricos:}

\subsubsection{Antecedentes regionais}

Piracicaba, que na lingua indigena significa "lugar onde 0 peixe para", ou "lugar onde há muito peixe", teve os indios como primeiros habitantes. Durante o inicio do seculo XVIII, várias bandeiras, à procura das famosas minas de ouro de Cuiabá, atravessaram a regiaao por picadas abertas nas florestas, ou descendo o rio em canoas, mas ainda năo havia se formado ali um povoado estável. Em 1765 , foi necessária a criaçáo de um posto avançado, para abastecer de viveres e muniçס́es as tropas da Vila Militar de Iguatemi, instalada na fronteira com o Paraguai para conter o avanço dos espanhois no Brasil. O governador-geral da capitania mandou entăo o capităo-povoador Antonio Corréa Barbosa, que estabeleceu o primeiro núcleo, à margem esquerda do rio Piracicaba, em $1^{\circ}$ de agosto de 1767 . Quando Iguatemi foi destruida pelos paraguaios, a pequena freguesia já tinha forças para crescer sozinha (CANABRAVA \& TEIXEIRA MENDES, 1938).

A antiga freguesia de Piracicaba foi elevada a vila com o nome de Vila Nova da Constituiçăo (em homenagem à Constituiçăo portuguesa) a 10 de agosto de 1822 , começando vida própria com sua Câmara e seu pelourinho. E como vila, sob sua jurisdição, estará todo um imenso território, cujas terras abrangem uma área enorme, que durante o seculo $X \mid X$, em sucessivos desmembramentos, irá se transformar em novas vilas, em evidente avanço dos perimetros urbanos sobre a zona rural (TORRES, 1975).

Em 1856, a localidade foi elevada à categoria de cidade, mas somente mais tarde, em 1877, restabeleceu-se o nome original de Piracicaba. Tinha entå 22 mil habitantes e 5 mil escravos, sendo que 4 mil habitavam o centro e o restante se espalhava pelas 4 fazendas de cana e 29 de café. Foi a agricultura que propiciou o desenvolvimento da regiầo de Piracicaba, desde os primórdios da sua história. O clima ameno, a topografia suave, a agua abundante e a riqueza dos solos definiram a sua vocaçăo agricola. Apesar de 
existirem muitas propriedades dedicadas a culturas diversas e a agropecuária, 0 café e a cana determinaram o crescimento económico do lugar (PREFEITURA MUNICIPAL DE PIRACICABA, 1988).

A ocupaçăo territorial da regiāo de Piracicaba obedeceu 0 modelo de colonizaçấo estabelecido pelo portugueses no Brasil, caracterizado pela exploraçăo de monoculturas em grandes propriedades rurais, tendo como máo-de-obra o braço escravo. No tempo do Novo Império, a doaçăo de sesmarias foi substituida pelo sistema de legitimaçăo de terras devolutas, ao passo que as sesmarias transmitidas pelo sistema juridico das partilhas ou meaçóes se fragmentaram, na sua maior parte, contribuindo para a divisáo paulatina da propriedade (TORRES, 1975).

Em 1896, Piracicaba e Capivari eram os dois maiores centros açucareiros do Estado. Mas a primazia da produçáo no municipio cabia ao café, que se tinha tornado a primeira riqueza da regiảo. Era citada também como a segunda localidade do Estado na produçăo de madeiras, cuja extraçato alcançava entăo $13.200 \mathrm{~m}^{3}$. De fato, a exploraçăo agricola exigiu um intenso desmatamento na região, a ponto de em 1930, apresentar a seguinte situação: Segundo CANABRAVA \& MENDES (1938) as propriedades agricolas têm uma pequena área ocupada por matas e capoeiras, reserva natural, mais como calorizaçăo (sic) do terreno, do que para consumo, mas a floresta tende a diminuir progressivamente, no aproveitamento de madeiras para marcenaria, além da utilizaçấo de algumas espécies para lenha e carváo.

A previsăo de diminuiçăo das florestas concretizou-se, pois os anos seguintes, a extraçăo de madeiras diminui de ritmo. De acordo o Serviço de Estatistica e Produçăo em 1954, Piracicaba e grande produtora de lenha e em pequena escala de madeira e carvăo vegetal. Naquele ano, produziu $330.000 \mathrm{~m}^{3}$ de lenha e a madeira extraida somou $3.200 \mathrm{~m}^{3}$ (IBGE, 1955).

Os vinte primeiros anos do século $X X$ foram o periodo de maior crescimento para Piracicaba: a populaçăo saltou de $\mathbf{2 5 . 3 7 4}$ habitantes, em 1900 para 67.732 habitantes, em 1920. Isto foi consequencia principaimente 
dos fluxos migratórios importados para trabalhar nas lavouras de café. $O$ processo de industrializaçäo em Piracicaba acelerou-se a partir dos anos 40 , devido as dificuldades de importações devido a Segunda Guerra Mundial. A cidade teve outro surto de desenvolvimento a partir da década de 60 , com a diversificação do parque industrial, atingindo seu ápice nos anos 70 , quando o Brasil vivia o auge do "milagre económico". Nessa epoca, comandado pelo capitalismo paulista, iniciou-se o processo de transferéncia da indústria pesada da metrópole para o interior e Piracicaba foi uma das cidades beneficiadas (PREFEITURA MUNICIPAL DE PIRACICABA, 1988).

O municipio foi também contemplado com o advento do PROALCOOL, na década de 80 , que expandiu a indústria de bens de produção do setor sucro-alcooleiro ali instalada. Mas năo conseguiu passar ao largo da grande crise nacional, que trouxe efeitos negativos para a economia local, a ponto do crescimento populacional e do produto interno ficarem bem abaixo das projeçóes otimistas existentes durante o inicio dos anos 80 .

Atualmente, novas perspectivas de progresso se abriram para a região com a implantação do sistema de navegação fiuvial - hiadrovia Tietê-Paraná - que, quando estiver concluida terá 6.400 quilômetros de extensão, levando, por barcaças, os produtos de Sāo Paulo até Itaipu, fronteira com o Paraguai (Figura 13). Espera-se que com ela se abram as portas da integração económica do Brasil com o Mercosul (Mercado Comum para o Cone Sul). Em dezembro de 1993, o governo do Estado de Sáo Paulo liberou recursos de 50 milhóes de dólares para a construção da barragem em Santa Maria da Serra, que permitira a navegabilidade do rio Piracicaba e sua inclusão no sistema hidroviário. Está prevista também a construção de um porto em Artemis, para receber as embarcações e a reativação do terminal ferroviário até Santos para facilitar o escoamento dos produtos (FOLHA DE S.PAULO, 27/02/94).

\subsubsection{Histórico da Estação Ecológica de Ibicatu}

Segundo PAVÃO (1987), Ibicatu, na lingua tupi-guarani, significa terra boa. A area em que se encontra Estação Ecológica era parte 
integrante da Fazenda Pau D'Alho, pertencente à ilustre familia Moraes Barros, berço de Prudente de Moraes, o primeiro presidente civil da República. A antiga fazenda foi dividida em quatro parcelas: a da sede, chamada Pau d'Alho, Pico do Alto, Boa Esperança e Santo Antonio de Ibicatu, cujo proprietário, Dr. Paulo de Moraes Barros Filho, em 1958, ofereceu ao entăo Secretário da Agricultura do Estado, a gleba de terra onde se encontravam os milenares jequitibás (ALMEIDA, 1992).

Foi efetuada então uma vistoria e avaliaçăo da área destinada à formaçăo de um parque fiorestal, cujo relatório data de 21 de julho de 1958 e é assinado pelo engenheiro agrónomo Francisco Moacyr Ayres de Alencar. Ele constatou "a importáncia da preservaçăo daquela pequena amostra da flora nativa em uma regiâo do Estado onde a cobertura florestal já quase năo mais existe." Considerou tambem "o relevante papel que desempenhará um parque florestal para a populaçăo dos municipios circunvizinhos, do ponto estético e recreativo" e definiu-o como um "campo ideal para estudos práticos e demonstrativos de Silvicultura para os alunos da Escola Superior de Agricultura "Luiz de Queiroz", pois dista esta Escola Universitária, apenas cerca de 30 quilómetros".

Desta forma, através do Decreto n. 33.261 , de 29 de julho de 1958, o imóvel foi declarado de utilidade pública pelo entáo Governador de Estado Janio da Silva Quadros, com os seguintes considerandos: "Compete ao Poder Público preservar todas as espécies vegetais autóctones no território do Estado de Sáo Paulo; considerando que o jequitiba - símbolo da terra paulista outrora abundante, escasseia dia a dia com risco de extinçăo da espécie; considerando que é indispensável garantir a sobrevivéncia desse representante precioso da nossa flora lenhosa; considerando que o municipio de Piracicaba năo conta com um parque florestal para fins educativos e recreativos; considerando ainda o imperativo do art. 116 da Constituiçăo do Estado de Săo Paulo - "O Estado e os Municipios preservarăo a fauna e a flora, criando-lhes reservas invioláveis." 
Em 26 de julho de 1978, o entăo governador de São Paulo, Paulo Egydio Martins, atraves do decreto 11.941 declarou de utilidade pública para fins de instituição de servidão de passagem pela Fazenda do Estado, por via amigável ou judicial, uma faixa de terreno com 27.600 metros quadrados, necessária ao Instituto Florestal do Secretaria da Agricultura.

Foi o governador Franco Montoro, que em 12 de março de 1987, através do decreto n. 26.890 transformou a antiga Reserva de lbicatu em Estaçăo Ecologica, com os seguintes considerandos: "Considerando ser de extrema necessidade, em funçăo da qualidade ambiental, a preservaçăo dos últimos remanescentes florestais do Estado; considerando que os remanescentes florestais da área objeto do presente decreto abrigam espécies de flora e fauna ameaçadas de extinçăo, cuja proteçăo é dever do Estado; considerando que as áreas de terra objetos do presente decreto, situadas nos municipios de Bananal, Bauru, Piracicaba, Itaberá, Mogi das Cruzes, Săo Carlos, Valinhos e Capáo Bonito constituem remanescentes florestais representativos no Estado, abrigando acervo de flora e fauna em condiçбes de serem preservadas para que as futuras geraçoes possam desfrutar os beneficios desta paisagem, para fins cientificos, culturais e educacionais, alem de seus valores como banco de germoplasma."

De acordo com este mesmo decreto, a Estaçăo Ecológica de Ibicatu ficou sob a administração do Instituto Florestal, orgăo da Coordenadoria da Pesquisa de Recursos Naturais, da Secretaria de Agricultura e Abastecimento, "aplicando-se as terras, flora, fauna e paisagem de sua área, as disposiçces da legislaçăo vigente". Com a criaçăo da Secretaria de Meio Ambiente, o Instituto Florestal passou sob sua jurisdiçăo. Em 1992, o Insttuto Florestal, tinha sob sua responsabilidade 17 Parques Estaduais, 3 Reservas Estaduais e 21 Estaçóes Ecológicas, somando 789.765,86 ha. (Instituto Florestal, 1992). 


\subsection{Aspectos biofisicos:}

\section{3,3.1. Geologia e geomorfologia}

A regiâo de Piracicaba está localizada na Depressăo Periferica, uma das cinco divisóes geomorfológicas do Estado de Sáo Paulo, citadas por ALMEIDA (1974), a saber: (I) Provincia do Planalto Attántico; (II) Província Costeira; (III) Depressão Periferica; (IV) Cuestas Basálticas e (V) o Planalto Ocidental.

Para AB'SABER (1974), a Depressão Periférica é descrita como um corredor embutido entre a Cuesta da Borda da Mata e Monte Santo e as elevaçóes cristalinas do acidentado planalto atlantico. De acordo com o IPT Instituto de Pesquisas Tecnológicas do Estado de Săo Paulo (1981), a Depressăo Periférica corresponde a faixa de ocorréncia das sequéncias sedimentares infra-basálticas paleozóicas e mesozóicas do Estado de Săo Paulo, sendo que pequenas áreas de rochas pré-cambrianas foram incorporadas a esta província. Os depósitos cenozóicos desta província acham-se essencialmente distribuidos segundo as principais linhas de drenagem, três das quais, aliás, a do Paranapanema, Tieté e Moji-Guaçu, constituem suas subdivisóes a nivel de zonas geomorfológicas (ALMEIDA, 1974; IPT, 1969).

Assim, de acordo com ALMEIDA (1974) a Depressão Periferica compreende três Zonas distintas: Paranapanema, Mogi-Guaçu e a Zona do Médio Tiete, onde se localiza a regiăo de Piracicaba. Esta Zona compreende uma área de $15.200 \mathrm{~km}^{2}$, portanto cerca de $2 / 5$ da área total da provincia. "Posto que em maior parte constituida de sedimentos, apresenta áreas importantes de derrames e intrusóes de rochas basálticas, que desempenham papel saliente na sua topografia. Mergulham as camadas em direçăo a noroeste, com inclinaçס̋es que crescem de uns $20 \mathrm{~m} / \mathrm{km}$ nas mais antigas do Grupo Tubaráo, a uns $3 \mathrm{~m} / \mathrm{km}$ somente, nos arenitos trássicos sobre que repousam os derrames basálticos.[...] Alem do mergulho regional, as camadas paleozóicas exibem, localmente, algumas perturbaçóes devidas a falhamentos, das quais a mais importante relaciona-se com a intrusáo de eruptivas alcalinas nas camadas carboniferas de Ipanema, fenómeno que bem se manifesta no relevo." 
Ainda segundo ALMEIDA (1974), a topografia da Zona do Médio Tieté é pouco acidentada, com desniveis locais que so excepcionalmente ultrapassam $200 \mathrm{~m}$. Por toda parte predominam colinas baixas, de formas suavizadas, separadas por vales jovens, sem planicies aluviais importantes, determinados pela interseção dos perfis convexos das vertentes. $E^{\prime}$ toda a zona coberta por rede de drenagem bem organizada, em cuja hierarquia se salientam trés rios: o Tiete e seus dois afluentes, os rios Piracicaba e Sorocaba, todos procedentes das terras elevadas do planalto cristalino.

De acordo com este mesmo autor, é certo que perturbações locais das camadas influem as vezes na preservaçăo das maiores elevaçóes nas áreas interfluviais. Isto é particularmente destacado numa linha de fraturas, orientada para Noroeste pela qual vazou o magma basáltico formador dos derrames das fazendas Vai-Vem e Milhã e dos Morros do Serrote, Pico Alto, São Pedro, Fortaleza e outros menores. Neste último, as culminancias basálticas alcançam cerca de 800 metros de altitude.

Segundo RANZANI (1966), predominam em Piracicaba as altitudes compreendidas entre $500-600 \mathrm{~m}$, sendo expostas em $61 \%$ da área do Municipio. Os pontos mais elevados, isto e, acima de 600 metros, cobrem apenas $9 \%$ da área do Municipio, enquanto os mais baixos que $500 \mathrm{~m}$. representam apenas $30 \%$ da sua área.

No final da decada de 30 , CANABRAVA \& MENDES (1938) descreveram a regiào da seguinte forma: "no seu aspecto geral, como uma vasta campina de suaves ondulaçóes; faz parte da regiáo central permiana, que, no seu conjunto, e uma larga depressa o que atravessa o Estado de Nordeste a Sudoeste. Nenhum acidente notavel quebra a monotonia da paisagem sem relevo; as altitudes médias variam entre 500 a 600 metros [...]. As camadas de silex formam entre o rio Piracicaba e o Rio Tiete uma serie de elevaçóes nas planicies arenosas; săo estruturas anticlinais como o morro do Pau D'Alho, provavelmente de origem ligada as rochas eruptivas que se devem encontrar em profundidade e que năo lograram atingir a superficie, como acontece em outros pontos, onde formam necks. Encontram-se ainda a 
Oeste e a Sudoeste de Piracicaba o anticlinal do Serrote $(675 \mathrm{~m}$ ), a dobra falhada Milhã - D. Pedro II. Mas são acidentes muito locais, de altitude muito reduzida, que năo tiram o traço de uniformidade de relevo que caracteriza a regiåo."

Segundo RANZANI (1966) a área do municipio de Piracicaba, embora em sua maior parte constituida de sedimentos, apresenta zonas de intrusão de rochas básicas que marcam acentuadamente a topografia e que desempenham importante papel na vida económica regional, sob o aspecto de oferecerem terras muito adequadas para a agricultura.

As camadas rochosas mergulham em direção a noroeste, com inclinaçőes maiores nas do Grupo Tubarăo, cerca de $15-20 \mathrm{~km}$. (bairros Tupi, Taquaral e Quebra Dente) e apenas $3 \mathrm{~m} / \mathrm{km}$ nos arenitos da Formaçăo Botucatu, sobre os quais repousam os derrames basalticos (bairros Anhumas, Giboia, Pinga e Paredão Vermelho). Devido ao mergulho das camadas, as rochas mais resistentes a erosâo destacam-se na topografia, constituindo pequenas cuestas que no municipio de Piracicaba săo mantidas por tilitos e "drifts" do Grupo Tubarão, calcários da Formação Irati e bancos de silex da Formaçăo Estrada Nova.

Ainda segundo este autor, de um modelo geral a topografia é pouco acidentada, com desniveis da ordem de 50-100 m. entre interflúvios e os vales, sendo que a altimetria varia entre $450 \mathrm{~m}$. na várzea do Tieté à sudoeste, até $750 \mathrm{~m}$. nos topos mantidos pelos "sills" de diabásio, no divisor Tieté Piracicaba (Morros São Joaquim, Monte Branco, Pau D'Alho, Boa Esperança e Pico Alto). Pode-se distinguir no município de Piracicaba a presença de três superficies gerais: alta, intermediária e baixa.

A superfície alta, onde está localizada a Estaçăo Ecológica de Ibicatu, ocorre "na porçăo central do municipio em área interfluvial, cujo testemunho de posição é apresentado pela estrutura do Pau D'Alho (Pico Alto, Monte Branco, Săo Joaquim, Serrote, Boa Esperança e Fortaleza), cujos cimos aplainados atingem cotas de 700-750 m. Esculpidos em arenito de Botucatu 
capeado de sedimentos quaternários, os seus pontos mais elevados correspondem a afloramentos de grande "sill" de diabásio que inclusive suspendeu sedimentos do grupo Passa Dois (Fazenda Boa Esperança). Essa superficie, outrora muito mais conspicua, hoje se restringe e ainda se mantém, apesar das sucessivas retomadas erosivas, graças a sua posição interfluvial e a resisténcia dos materiais silicificado e magmático. Trata-se do mais antigo aplainamento levado a efeito na Depressâo Periferica, sob clima semi-árido" (RANZANI, 1966).

\subsubsection{Solos:}

De acordo com RANZANI et alli (1966) o solo na regiấo que compreende a Estaçăo Ecológica de lbicatu está classificado na série Anhumas, cujas caracteristicas principais sâo: perfis profundos, tendendo a originar um horizonte B estreito e incipiente. Este tipo ocorre nas encostas, sustentando divisores de água de primeira e segunda ordem e sáo sujeitos a mecanismos de podzolizaçăo. Seu perfil é o seguinte:

AP 0-50 cm; pardo escuro (7,5 YR 4/2;3/2 úmido); barro arenoso fino; maciço; ligeiramente duro, friável, ligeiramente plástico, não pegajoso; raízes

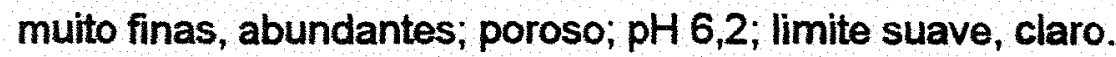

B/C 50-70 cm; pardo escuro 97,5 YR 4/3,3/3 úmido; barro arenoso fino; maciço, com tendéncia a ruptura em blocos médios, muito fraco; ligeiramente duro, friavel, nåo plástico, nāo pegajoso; macroporos comuns; raizes muito finas, abundantes; $\mathrm{pH} 6,3$; limite ondulado, claro.

C/R 70-85 cm.; pardo $(7,5$ YR 5/4; $4 / 4$ úmido) areia barrenta fina; com fragmentos do material de origem esparsos; macio, friável, não plástico, não pegajoso, $\mathrm{pH} \mathrm{4,9;} \mathrm{limite} \mathrm{descontínuo.}$

$\mathrm{R} 85-100 \mathrm{~cm}$; arenito consolidado fragmentando-se em tijolinhos, amareloavermelhado (5 YR 6/6), seguindo-se camada amarelo-avermelhada (7,5 YR $6 / 8$ ) e branca (5 YR 8/1) exteriormente. As ralzes finas penetram aproximadamente $40 \mathrm{~cm}$. neste horizonte, acomodando-se nos planos entre os tijolinhos. 
de Campinas, o solo existente na area de lbicatu é um agrupamento indiferenciado de latossolo vermelho-amarelo e podzólico vermelho-amarelo distróficos. O Horizonte A é moderado, textura média, intermediários com Areia Quartzosa, Unidade São Pedro (Quartzpsamentic haplorthox e Psammentic paleudulf), conforme pode ser observado na Figura 7. 


\section{Figura 7 - \\ MAPA PEDOLÓGICO DO ENTORNO DA ESTAÇÃO ECOLÓGICA DE IBICATU}

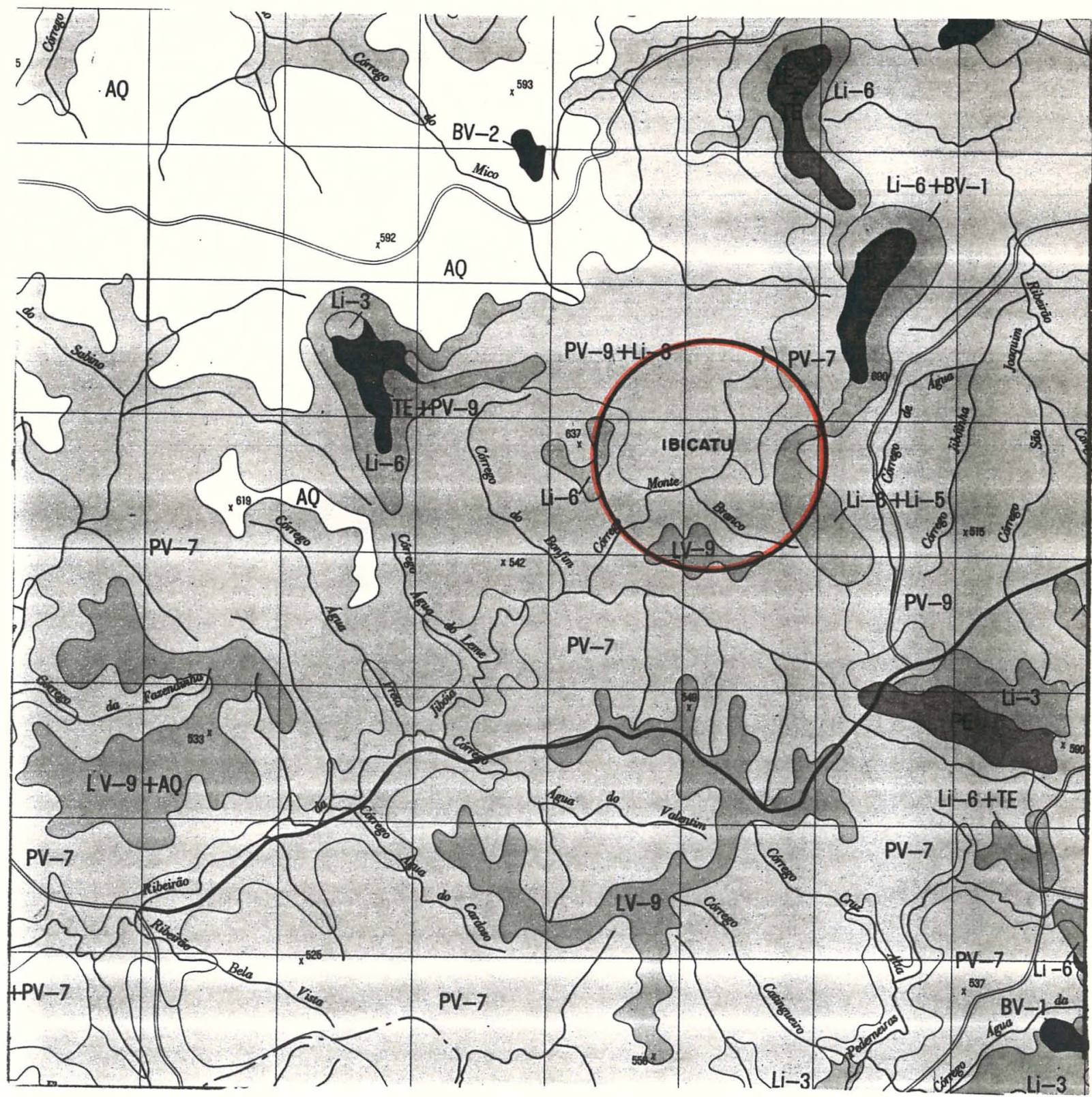




\section{(Continuaçăo) -Figura 7}

\section{Legenda:}

\section{LATOSSOLOS ROXOS}

LR-1 LATOSSOLO ROXO EUTRÓFICO, A moderado, textura muito argilosa ou argilosa Unidade Ribeirăo Preto (Typic Eutrorthox)

LR-2. LATOSSOLO ROXO DISTROFICO OU ÁLICO, A humico, textura muito argilosa Unidade Nogueira (Pachic Umbriorthox).

LR-3 LATOSSOLO ROXO DISTROFICO, A moderado, textura muito argilosa ou argilosa. Unidade Barăo Geraido (Typic Haplorthox)

\section{LATOSSOLOS VERMELHO-ESCUROS}

LE-1 LATOSSOLO VERMELHO ESCURO ALICO, A moderado, textura media Unidade Hortolandia. (Typic Haplorthox).

LE-2. LATOSSOLO VERMELHO-ESCURO ALICO, A moderado, textura argilosa ou muito argilosa. Unidade Limeira (Typic Haplorthox).

LE-3 LATOSSOLO VERMELHO ESCURO ALICO, A moderado, textura argilosa ou muito argilosa. Unidade Santo Antonio. (Typic Haplorthox)

\section{LATOSSOLOS VERMELHO-AMARELOS}

IV-1. LATOSSOLO VERMELHO AMARELO ALICO, A moderado, textura media Unidade Coqueiro (Quartzsipsammentic Haplorthox e Typic Haplorthox).

LV-2 LATOSSOLO VERMELHO AMARELO ALICO, A moderado textura media. Unidade Laranja Azeda. (Typic Haplorthox).

LV-3. LATOSSOLO VERMELHO AMARELO ALICO, A proeminente, textura media Unidade Trés Barras. (Typic Haplorthox e Typic Umbiorthox).

LV-4. LATOSSOLO VERMELHO AMARELO ALICO, A proeminente, textura argilosa. Unidade Alto da Serra (Typic Umbriorthox)

LV-5 LATOSSOLO VERMELHO AMARELO ALICO, A moderado, textura argilosa, Unidade Mato Dentro (Typic Haplorthox)

IV-6. LATOSSOLO VERMELHO-AMARELO ALICO, A húmico, textura muito argilosa. Unidade Itororó. Typic Haplorthox e Typic Umbriorthox

LV-7. LATOSSOLO VERMELHO AMARELO ALICO, A húmico, textura média ou argilosa. Unidade Camarguinho.(Pachic Umbriortnox)

LV-8. LATOSSOLO VERMELHO AMARELO ALICO, A proeminente, textura argilosa cascalhenta fase pedregosa $1 / 1$, Unidade Itaqueri (Plintic Acrohumox?).

LV-9 Grupamento indiferenciado de LATOSSOLO VERMELHO AMARELO e de PODZOLIICO VERMELHO AMARELO Distróficos. A moderado textura média, intermediários com AREIA QUARTZOSA.Unidade S.Pedro. (Quartzipsammentic Haplorthox e Psammentic Paleudult)

\section{PODZÓLICOS VERMELHO - AMARELOS}

PV-1. PODZOLICO VERMELHO AMARELO DISTROFICO OU ALICO Tb, A moderado, textura média ou arenosa/média. Unidade Usina. (Typic Paleudult)

PV-2 PODZOLICO VERMELHO AMARELO DISTROFICO OU ALICO Tb A moderado, textura argilosa. Unidade Olaria. (Typic Paleudult)

PV-3 PODZOLICO VERMELHO AMARELO PLANOSSOLICO EUTRÓFICO Ta, A moderado, textura média/argilosa Unidade Tieté (Albiaquic? Paleudalf, Albiaquic? Vertic Paleudalf).

PV-4 Grupamento indiscriminado de PODZOLICOS VERMELHO AMARELOS abruptos, A moderado e espesso, textura arenosa/media Unidade Alva (Arenic Abruptic Paleudalf $e$ Arenic Abruptic Paleudult)

PV-5 Grupamento indiscriminado de PODZOLICOS VERMELHO AMARELOS abruptos, A moderado, textura arenosa/media, pouco profundos Unidade Alva fase pouca profunda. (Arenic Abruptic Paleudalf e Arenic Abruptic Paleudult)

PV-6- Grupamento indiscriminado de PODZOLICOS VERMELHO AMARELOS Tb, A moderado, textura arenosa/média ou média Unidade Baquari (Typic Paleudalf e Typic Paleudult)

PV-7 Grupamento indiscriminado de PODZÓLICOS VERMELHO-AMARELOS abruptos, A moderado e espesso, textura arenosa/média Unidade Serrinha (Arenic Abruptic Paleudalt, Arenic Abruptic Paleudult)

PV-8 Grupamento indiscriminado de PODZOLICOS VERMELHO AMARELOS abruptos, A moderado e espesso, textura arenosa/média pouco profundos. Unidade Serrinha tase pouco profunda. (Arenic Abruptic Paleudalf, Arenic Abruptic Paleudult)

PV-9. Grupamento Indiscriminado de PODZOLICOS VERMELHO-AMARELOS Tb abruptos, A moderado, textura arenosa/argilosa ou média/argilosa. Unidade Santa Cruz. (Abruptic Paleudalf, Abruptic Arenic Paleudalf, Abruptic Paleudult e Abruptic Arenic Paleuduit).

PV-10-Grupamento indiscriminado de PODZOLICOS VERMELHO-AMARELOS EUTROFICOS, A moderado, textura média/argilosa pouCo profundos Unidade Manduca (Abruptic Paleudalf e Typic Paleudalf)

PV-11-Grupamento indiscriminado de PODZOLICOS VERMELHO-AMARELOS com cascalho e / ou cascalhentos. (Alfisol Udalf e Udult)

\section{PODZÓLICOS VERMELHO-ESCUROS}

PE - Grupamento indiscriminado de PODZOLICOS VERMELHO-ESCUROS, textura argilosa ou argilosa / muito argilosa com ou sem cascalho. Unidade Campestre. (Typic Paludult, Typic Paleudalf e Typic Arguidoll). 


\section{(Continuaçăo) - Figura 7}

\section{Legenda:}

\section{TERRA ROXA ESTRUTURADA}

TE - TERRA ROXA ESTRUTURADA EUTROFICA, A moderado, textura argilosa ou muito argilosa. Unidade Estruturada. (Rhodic Paleudalf)

\section{TERRA ROXA ESTRUTURADA LATOSSÓLICA}

TEL - TERRA ROXA ESTRUTURADA LATOSSOLICA EUTROFICA OU DISTROFICA, A moderado, textura argilosa ou muito argilosa. Unidade Itaguaçu. (Rhodic Paleudalf e Rhodic Paleudult)

\section{TERRA ROXA ESTRUTURADA PODZÓLICA}

TEP - TERRA ROXA ESTRUTURADA PODZOLICA EUTROFICA, A chernozemico, textura média/argilosa. Unidade Santana.(Typic Arguidoll).

\section{BRUNIZENS AVERMELHADOS}

BV-1. BRUNIZEM AVERMELHADO, textura argilosa, substrato diabásio. Unidade Engenho. (Typic Arguidoll). BV-2-BRUNIZEM AVERMELHADO, textura argilosa, substrato sedimentos peliticos. (Typic Arguidoll)

\section{PODZOL}

PH PODZOL (?) HUMICO EUTRÓFICO Ta, A chernozemico, textura arenosa, pouco profundo ( HUmod?).

\section{CAMBISSOLOS}

C-1 CAMBISSOLO ALICO Tb, A moderado, textura indiscriminada, bem a imperfeitamente drenado. Unidade Sete Lagoas (Fluvaquentic Dystrochrept e Typic Distrochrept).

C-2 Grupamento indiscriminado de CAMBISSOLO Tb, A moderado, Unidade Taquaraxim. (TypIC Dystrochrept).

C-3 CAMBISSOLO ALICO Tb, A moderado, textura media, Unidade Palha. (Typic Dystrochrept).

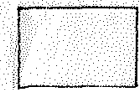

\section{AREIA QUARTZOSA}

AQ AREIA QUARTZOSA ALICA profunda e pouco profunda, A moderado. (Typic Quartzipsamment)

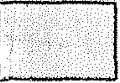
SOLO ALUVIAL

A - Grupamento indiscriminado de SOLOS ALUVIAIS, (Fluvent).

\section{SOLOS LITÓLICOS}

LI-1 - SOLOS LITOLICOS cascalhentos indiscriminados.

Li-2 - SOLO LITÓLICO EUTRÓFICO OU DISTROFICO, A moderado, proeminente ou chernozémico, textura media, substrato sedimentos indiscriminados do Grupo Tubarảo. (Typic Udorthent).

LI-3 SOLO LITOLICO EUTROFICO OU DISTROFICO, A moderado, proeminente ou chernozémico, substrato sedimentos indiscriminados do Grupo Passa Dois. (Typic Udorthent).

Li-4 - SOLO LITOLICO EUTRÓFICO vertico, A moderado, sedimentos indiscriminados do Grupo Passa Dois. (Vertic Udorthent e Vertic Lithic Hapludoll).

L-5 - SOLO LITOLICO EUTRÓFICO, A moderado ou chernozemico, substrato arenitos das formaçoes Botucatu ou Pirambóia (Typic Udorthent e Lithic Hapludoll).

Li-6 - SOLO LITOLICO EUTROFICO, A moderado ou chernozémico, substrato basalto ou dlabásio. (Lithic Udorthent e Lithic Hapludolli.

Li-7 - SOLO LITOLICO EUTROFICO, A moderado, substrato sedimentos indiscriminados do Grupo Bauru. (Typic Udorthent). 


\subsubsection{Clima}

O tipo climático regional, de acordo com a classificaçăo de Köppen pertence ao tipo Cwa, mesotérmico, úmido com inverno seco, temperatura média do més mais quente acima de $22^{\circ}$, podendo ocorrer geadas esporádicas durante 0 inverno. A precipitação média anual em Piracicaba é próxima de $1.257 \mathrm{~mm}$., predominando no semestre mais quente; os meses mais chuvosos sāo dezembro, janeiro e fevereiro; a temperatura média anual e de $20,8^{\circ} \mathrm{C}$ e a do mes mais frio é de $16,7^{\circ} \mathrm{C}$. A umidade relativa media é de $69 \%$ (Fonte: Posto Agrometeorológico do Departamento de Fisica e meteorologia da ESALQ, localizado nas coordenadas $2^{\circ} 42^{\prime} 30^{\prime \prime}$, latitude sul e $47^{\circ} 38^{\prime} 00^{\prime \prime}$, longitude oeste de Greenwich, a uma altitude de $546 \mathrm{~m}$. acima do nivel do mar).

Ainda de acordo com o Departamento de Fisica e Meteorologia da ESALQ, verifica-se que o perlodo de maior radiaçăo global coincide com o inicio do periodo de maior precipitaçăo e de maior temperatura, ocorrendo perto do final do ano, durante novembro e dezembro. A insolaçáo apresenta uma variaçăo mensal de 200 horas, demonstrando năo existir no decorrer do ano, uma redução considerável da quantidade de luz direta.

O balanço hídrico climatologico de Thornthwaite demonstra que há um armazenamento de água no perfil do solo no mês de dezembro. A frequéncia de ocorrencia de geadas na regiăo de Piracicaba no periodo de observaçá, entre os anos de 1900-1975 apresenta uma geada severa a cada cinco anos e uma geada severissima a cada 25 anos. Predominam ventos na direçăo Este, no horário das $7 \mathrm{~h}$ as $21 \mathrm{~h}$, sendo intercalados com ventos predominantes na direção Sudeste, no horário das $14 \mathrm{~h}$., conforme dados posto meteoragrário da ESALQ (1990).

A partir dos gráficos que representam as médias móveis de temperatura do ar atmosférico coletados no Posto Agrometeorológico da ESALQ no periodo de 1917 a 1990 , OMETTO (1991) constatou que a linha das temperaturas médias anuais vai crescendo sistematicamente, indo do valor $20^{\circ} \mathrm{C}$ 
no decénio 1917 a 1926 , ao valor $21,5^{\circ}$ no decénio 1953 a 1962 . As linhas das temperaturas mínimas e máximas no periodo de 1917 a 1946 sobem em torno de $0,5^{\circ} \mathrm{C}$, enquanto, no mesmo periodo, a temperatura média sobe $1^{\circ} \mathrm{C}$. Isto mostra a tendéncia da temperatura do ar em ficar mais tempo elevada, situaçăo típica de diminuiçăo da vegetaçăo. A tendéncia se acentua a partir do decénio 1937 a 1946, quando a temperatura minima decresce rapidamente, continuando a média a subir e estabilizando-se a máxima. Nesse periodo intensifica-se a diminuição da vegetaçăo. A partir de 1946 a 1962 a situaçăo fica constante em termos de cobertura de solo. OMETTO (1991) conclui finalmente que a partir de 1963, diminui a temperatura máxima, juntamente com a temperatura media, mostrando dessa maneira o aumento da vegetaçåo sobre o solo (Tabela 3). 
Tabela 3 .

\section{CONDIÇÓES CLIMÁTICAS MÉDIAS NO \\ MUNICIPIO DE PIRACICABA - $1917 / 1970$}

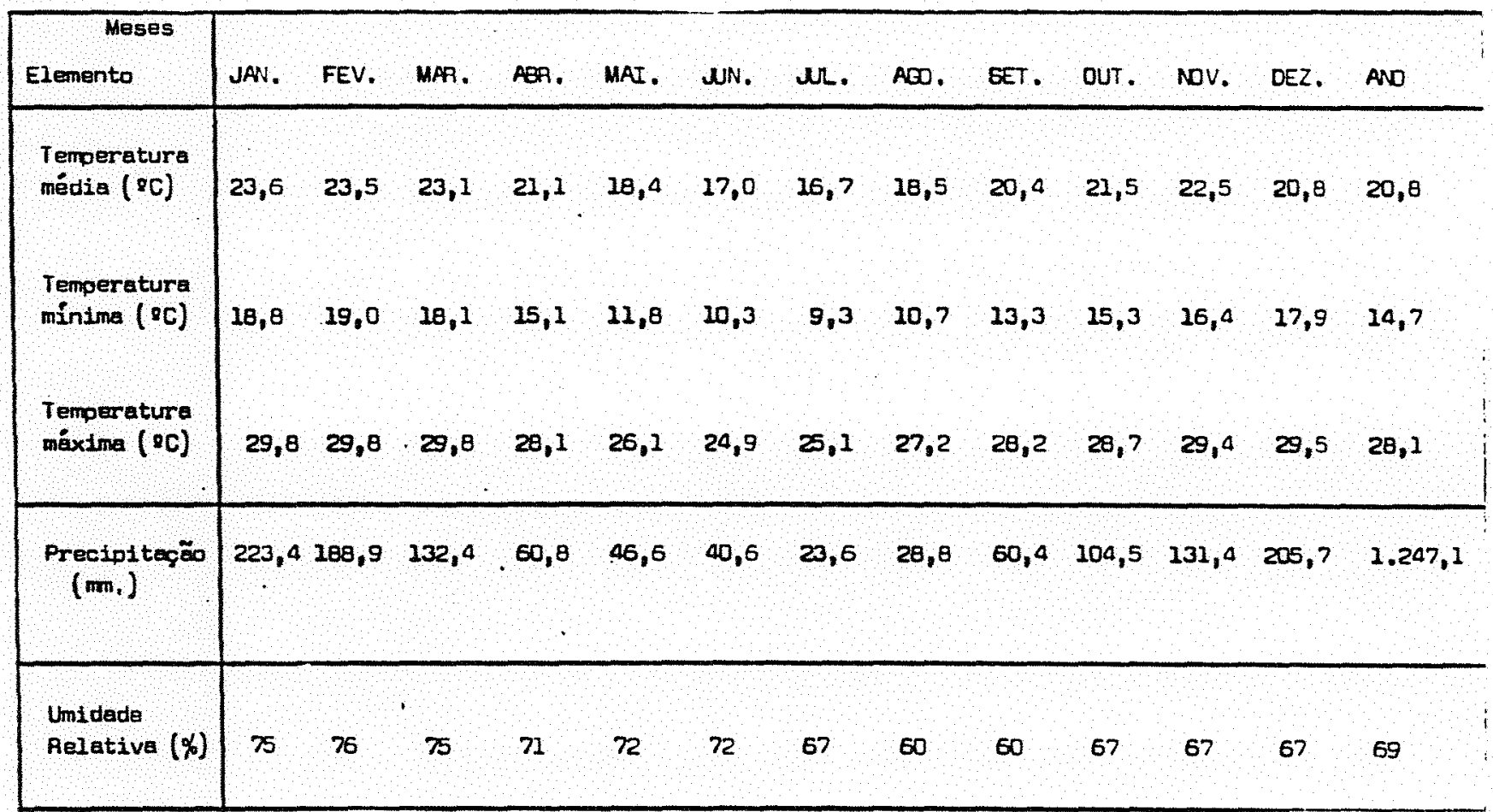

\section{Fontes:}

Posto Agrometeorologico situado a $22^{\circ} 42^{\prime} 30^{\circ} \mathrm{s}$ e $47^{\circ} 38^{\circ} 00^{\circ} \mathrm{W}, 546 \mathrm{~m}$. altitude Departamento de Fisica e Meteorologia da ESALQJUSP - Piracicaba 
Figura 8 - PRECIPITAÇÓES PLUVIOMÉTRICAS MÉDIAS MENSAIS NO MUNICÍPIO DE PIRACICABA - 1917 - 1970

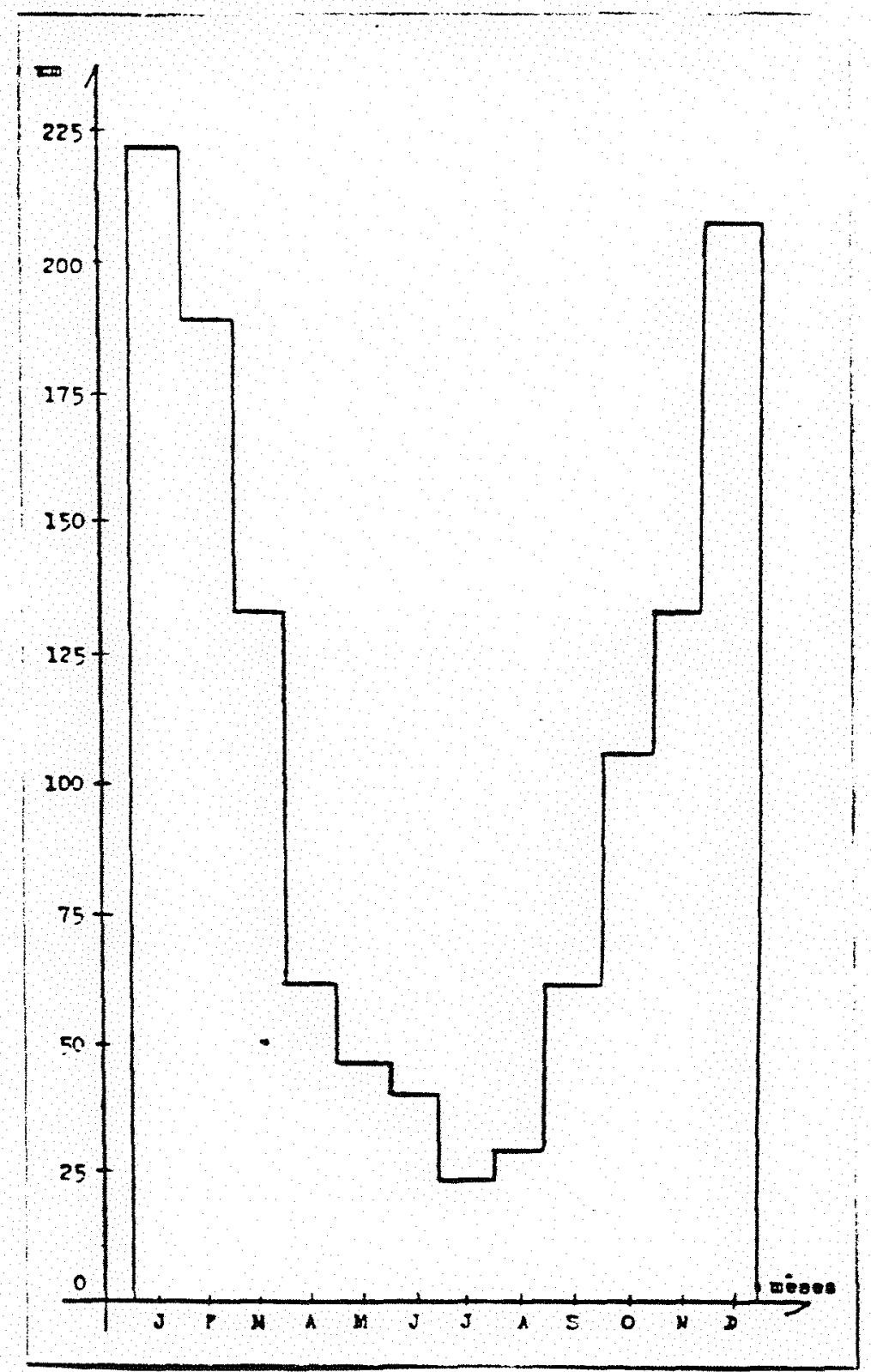

Fontes:

Posto Agrometeorologico situado a $22^{\circ} 4230^{\prime \prime} \mathrm{s}$ e $47^{\circ} 38^{\circ} 00^{\prime \prime} \mathrm{W}, 646 \mathrm{~m}$. alttude Departamento de Fisica e Meteorologia da ESALQ/USP - Piracicaba 
Figura 9- BALANÇO HÍDRICO CLIMATOLÓGICO METTODO: THORNTHWAITE

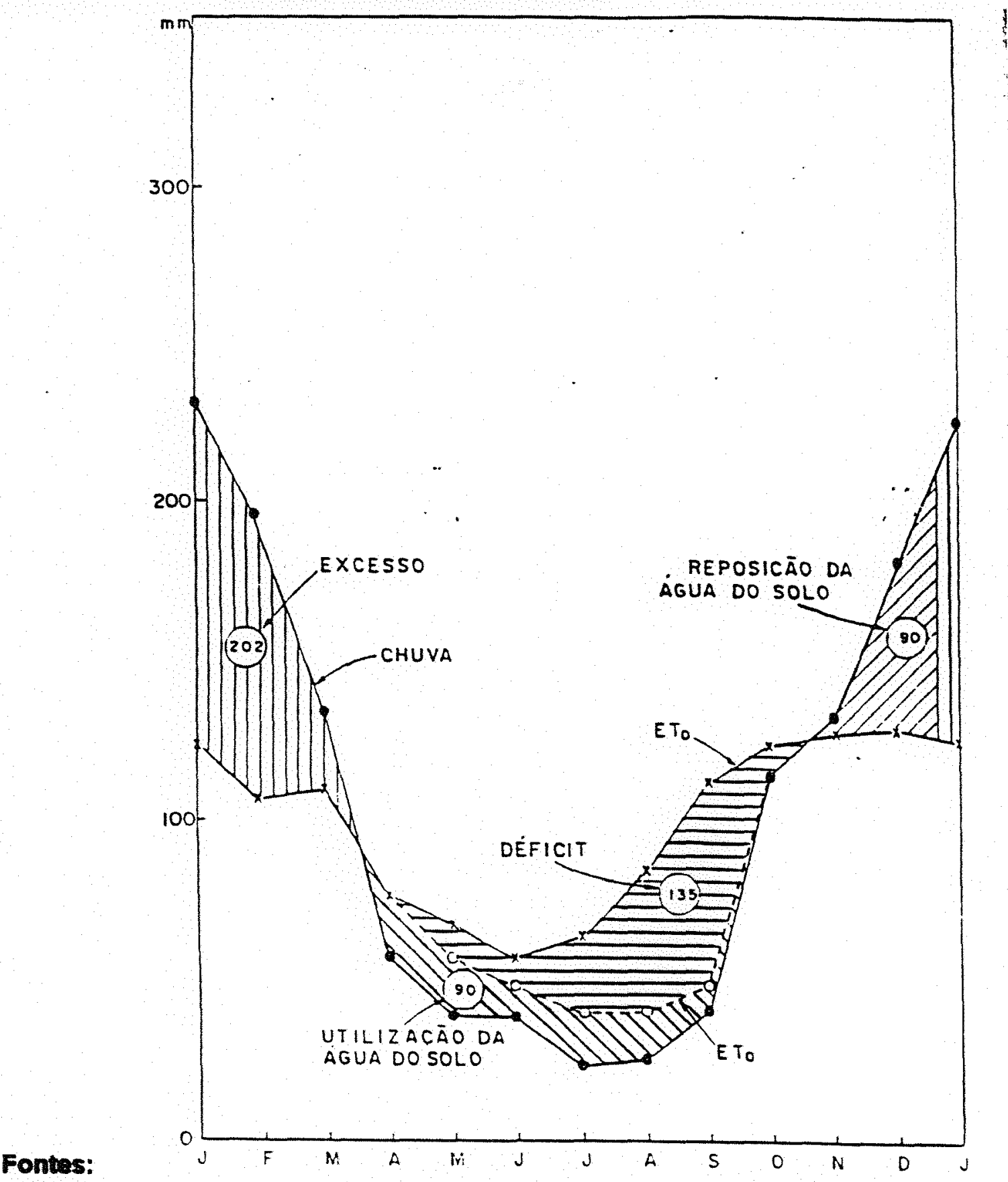

Posto Agrometeorológico situado a $22^{\circ} 42^{\circ} 30^{\mathrm{n} s}$ e $47^{\circ} 38^{\circ} 00^{\prime \prime} \mathrm{W}, 548 \mathrm{~m}$. alttude Departamento de Fisica e Meteorologia da ESALQUSP - Piracicaba 
Tabela 4 - RESULTADOS NUMÉRICOS DO BALANÇO HIDRICO DE PIRACICABA - SP

Método: Thornthwalte a Mather (1955) Para: $100 \mathrm{~mm}$. de retencão de água no solo

\begin{tabular}{|c|c|c|c|c|c|c|c|c|c|c|}
\hline \multirow[b]{2}{*}{ MESES } & \multirow[b]{2}{*}{$\begin{array}{l}\text { TEMP. } \\
\text { D. }\end{array}$} & \multicolumn{6}{|c|}{ MILIMETAOS PLUVIOMÉTRIDOS } & \multirow[b]{2}{*}{$\begin{array}{l}\text { Evapor. } \\
\text { Real }\end{array}$} & \multirow[b]{2}{*}{ Defic. } & \multirow[b]{2}{*}{ Exced. } \\
\hline & & $\begin{array}{l}\text { Precip. } \\
\text { (P) }\end{array}$ & $\begin{array}{l}\text { Evapor } \\
\text { potencial } \\
\text { (EP) }\end{array}$ & $\begin{array}{l}\text { Galdos } \\
(P-E P)\end{array}$ & $\begin{array}{l}\text { Neg. } \\
\text { Acum. }\end{array}$ & Armaz. & Alter. & & & \\
\hline Janetro & 23,6 & 234 & 124 & 110 & - & 100 & 20 & 124 & 0 & 90 \\
\hline Fevereiro & 23,5 & 196 & 107 & 89 & - & 100 & 0 & 107 & 0 & 89 \\
\hline Março & 23,1 & 137 & 114 & 23 & - & 100 & 0 & 224 & 0 & 23 \\
\hline Abr11 & 21,1 & 59 & 79 & -20 & 20 & 81 & -19 & 78 & 1 & 0 \\
\hline Maio & 18,4 & 41 & 68 & -27 & 47 & 62 & -19 & 60 & 8 & 0 \\
\hline Junto & 17,0 & 40 & 60 & -20 & 67 & 50 & -12 & 52 & 8 & 0 \\
\hline Juitho & 16,7 & 23 & 67 & -44 & 111 & 32 & -18 & 41 & 26 & 0 \\
\hline Agosto & 18,5 & 27 & 87 & -50 & 121 & 17 & -15 & 42 & 45 & 0 \\
\hline Setembro & 20,4 & 46 & 96 & -50 & 220 & 10 & -7 & 53 & 43 & 0 \\
\hline Dutubro & 21,5 & 121 & 125 & -4 & 224 & 10 & 0 & 121 & 4 & 0 \\
\hline Novembro & 22,5 & 139 & 132 & 6 & 178 & 16 & 6 & 132 & 0 & 0 \\
\hline Dezembro & 23,2 & 195 & 131 & 64 & $\Delta 4$ & 80 & 64 & 131 & 0 & 0 \\
\hline Ano & 20,8 & 1.257 & 1.190 & 67 & & & & 1.055 & 135 & 202 \\
\hline
\end{tabular}

Fontes:

Posto Agrometeorológico situado a $22^{\circ} 42^{\prime} 30^{\circ} \mathrm{S}$ e $47^{\circ} 38^{\circ} 00^{\circ} \mathrm{W}, 646 \mathrm{~m}$. altitude Departamento de Fisica e Meteorología da ESALQUSP - Piracicaba 
Figura 10 - DISTRIBUIÇAO DAS TEMPERATURAS MAXIMAS E MINIMAS PARA A REGIÃO DE PIRACICABA-SP - 1981-1990

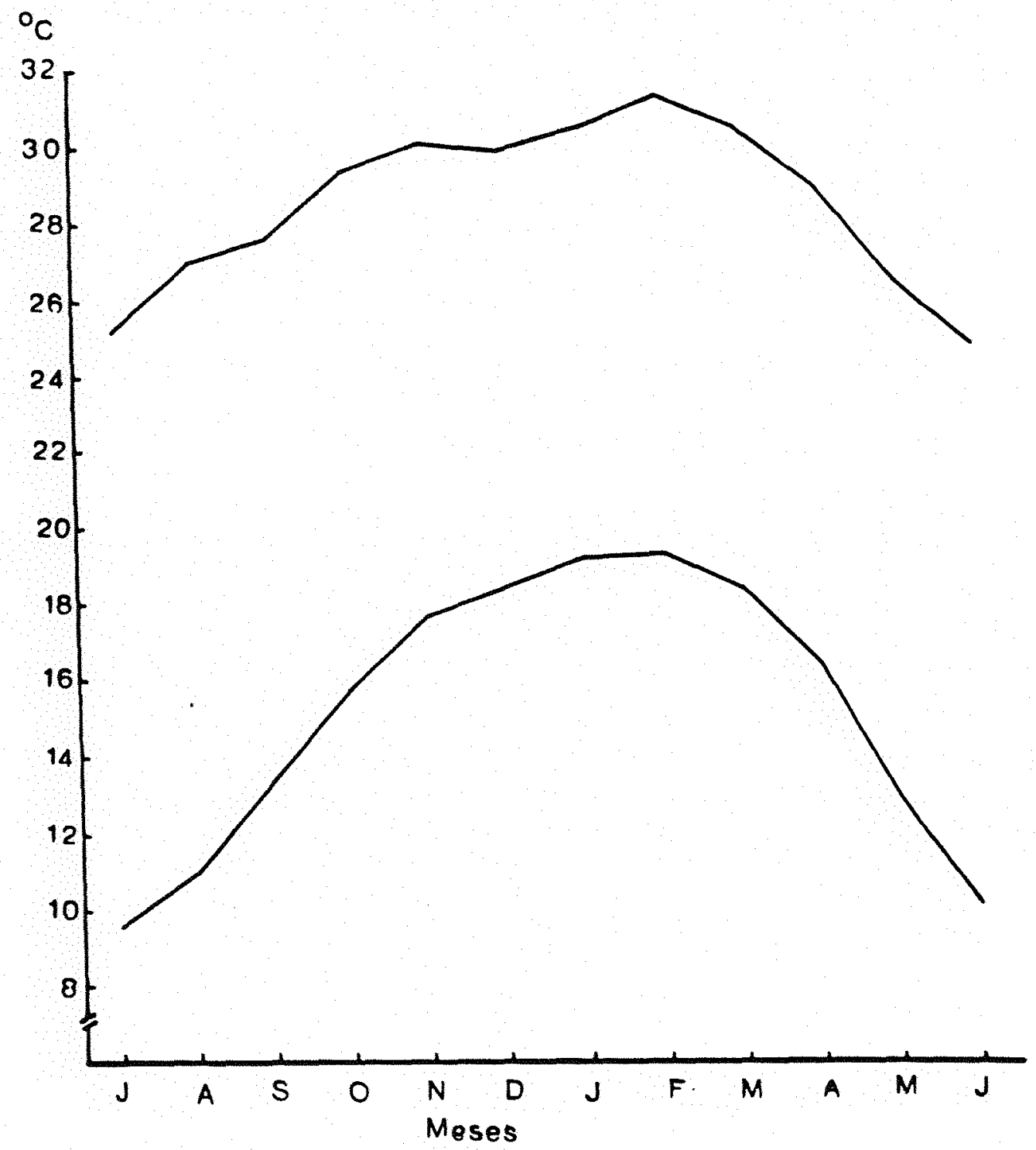

Fontes:

Posto Agrometeorologico situado a $22^{\circ} 42^{\prime} 30^{\prime \prime} \mathrm{s}$ e $47^{\circ} 38^{\circ} 00^{\mathrm{m}} \mathrm{W}, 646 \mathrm{~m}$. altutude Departamento de Fisica e Meteorologia da ESALQUSP - Piracicaba 
Figura 11 - DISTRIBUIÇÃO DA RADIAÇAO SOLAR PARA

A REGIÃO DE PIRACICABA - 1981 - 1990

$\mathrm{Cal} / \mathrm{m}^{2}$

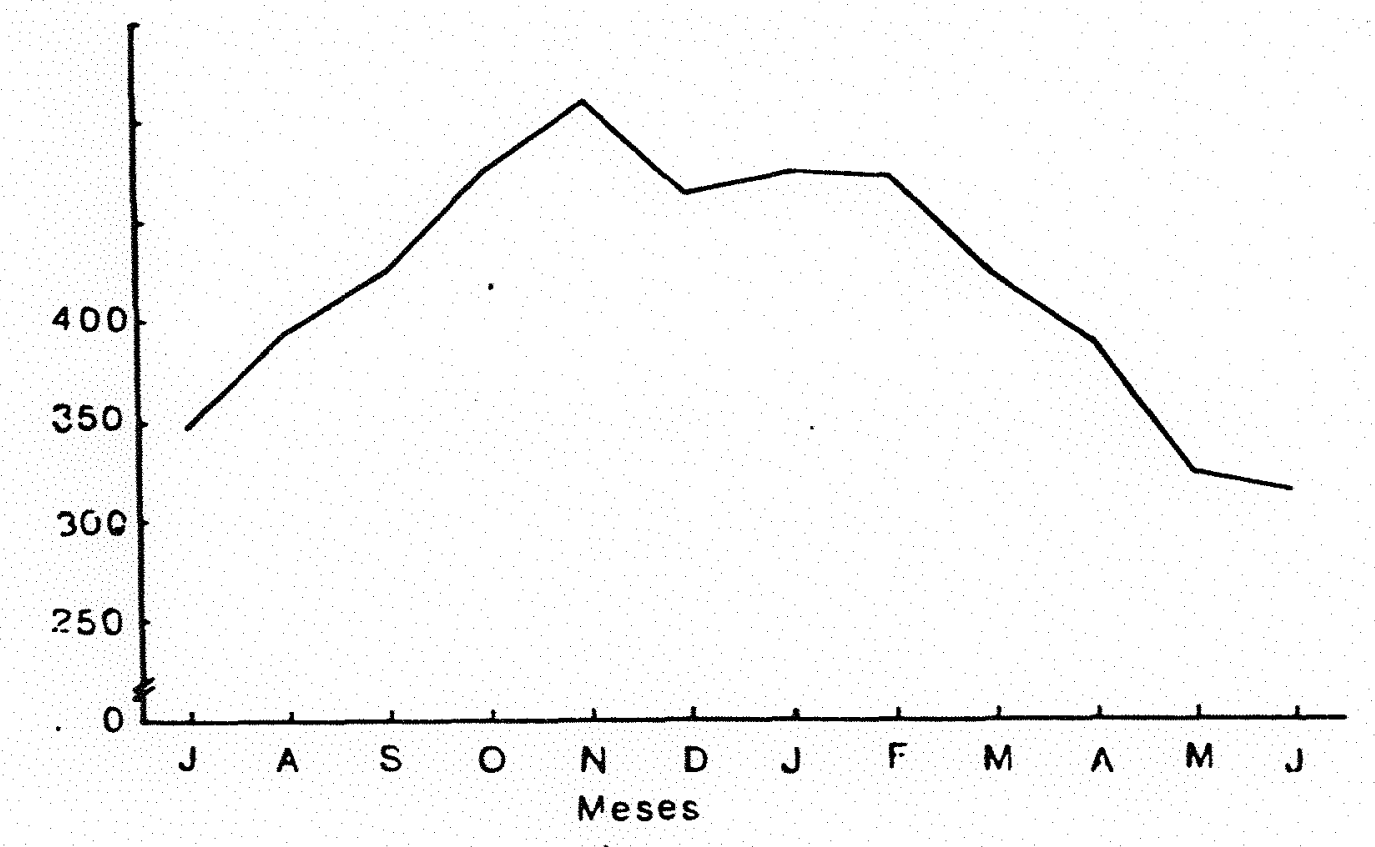

Fontes:

Posto Agrometeorologico situado a $22^{\circ} 42^{\prime} 30^{\prime \prime} \mathrm{s}$ e $47^{\circ} 3^{\circ} 00^{\prime \prime} \mathrm{W}, 646 \mathrm{~m}$. altitude Departamento de Fisica e Meteorologia da ESALQJUSP - Piracicaba 
Figura 12 - DISTRIBUIÇÃO DA INSOLAÇAOO PARA A REGIÃO DE PIRACICABA - 1981-1990

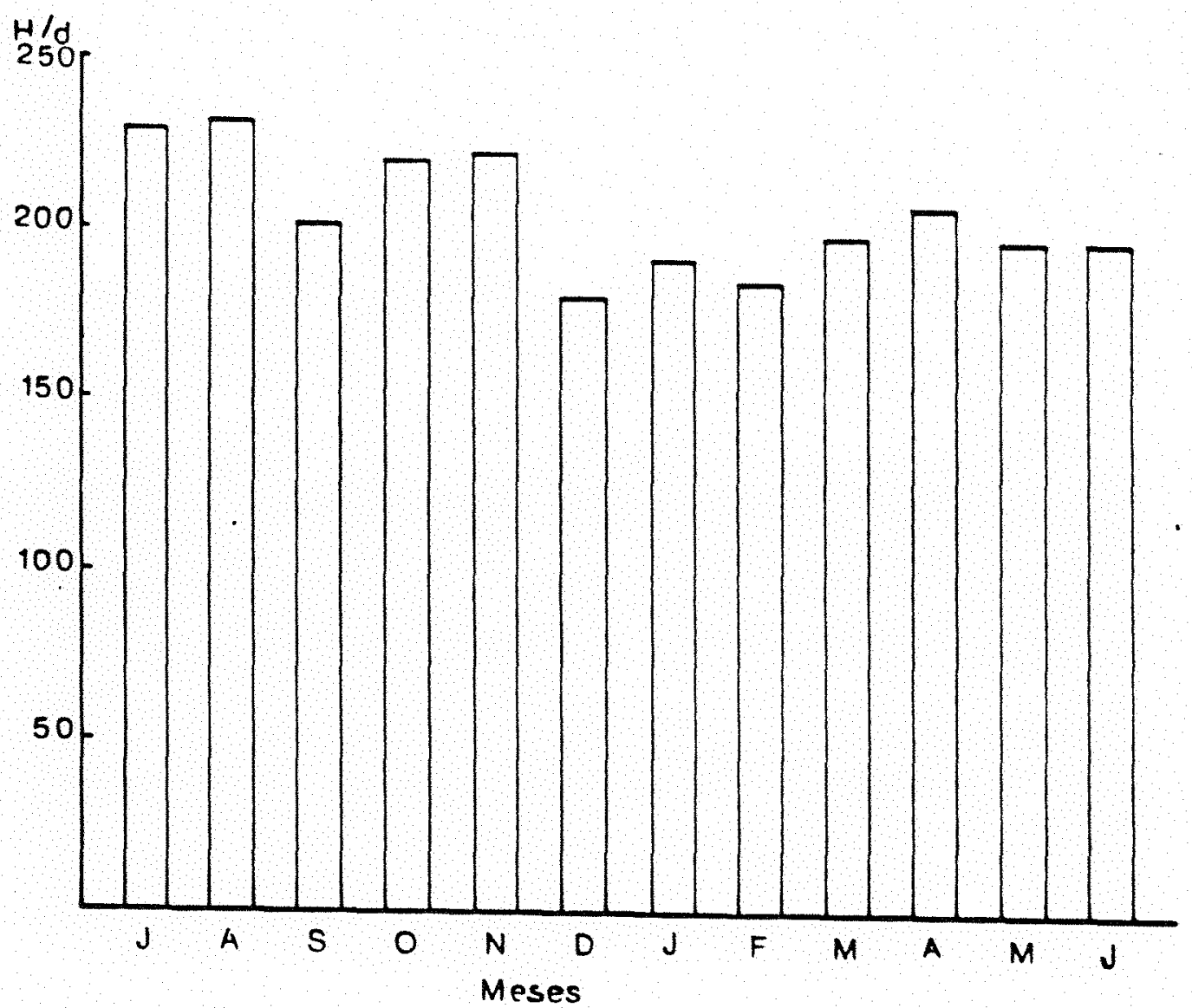

Fontes:

Posto Agrometeorológico situado a $22^{\circ} 42^{\circ} 30^{\prime \prime s}$ e $47^{\circ} 38^{\circ} 00^{\prime \prime} \mathrm{W}, 546 \mathrm{~m}$. altitude Departamento de Física e Meteorologia da ESALQUSP - Piracicaba 


\section{Tabela 5 - VELOCIDADE MÉDIA DO VENTO $(\mathrm{m} / \mathrm{s})$}

PIRACICABA - SP - $1943-1970$

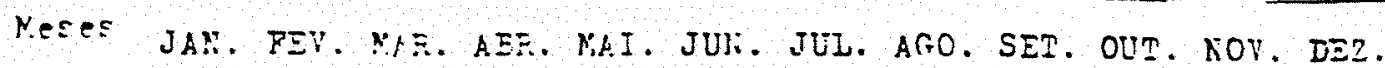
it nos

\begin{tabular}{|c|c|c|c|c|c|c|c|c|c|c|c|c|}
\hline $108^{2}$ & 1,6 & 2,7 & 2,4 & 3,7 & 1,2 & 1,1 & $1, ?$ & 2,4 & 1,0 & $?, 0$ & 2,0 & 2,7 \\
\hline 44 & 1,8 & 2,5 & 1,5 & 2,7 & $1, \epsilon$ & 1,7 & 1,8 & 2,0 & 7,0 & 2,0 & 1,9 & $2, ?$ \\
\hline 45 & 2,2 & 1,4 & 2,0 & 1,7 & $1, \epsilon$ & 1,5 & 1,9 & 1,5 & 2,4 & 2,0 & 2.9 & 2.9 \\
\hline$\Delta \varepsilon$ & 2,5 & 2,0 & 2,3 & 7,1 & 2,0 & 1,8 & 2,0 & 1.9 & 2,3 & 2,2 & 2,0 & 2.0 \\
\hline 47 & 1,9 & 2,5 & 2,2 & $\cdots$ & 2,5 & 1,6 & 1,9 & 1,9 & 2,2 & $?, 3$ & 2,6 & 2,5 \\
\hline 45 & 2.7 & 1. & $\therefore, 0$ & 2,5 & 2,2 & 2.5 & 2.2 & 2,2 & 2.5 & 2,5 & $\therefore, \epsilon$ & 1,0 \\
\hline 49 & $2, c$ & 1,9 & 1,5 & 1,7 & 1,4 & 1,6 & 1,4 & 2,2 & 2,1 & $2, ?$ & 2,2 & 1,2 \\
\hline 1050 & 1,2 & 1.5 & 1,9 & 2,2 & 1,4 & 1,5 & 1,3 & 1,8 & 2,3 & 2,0 & 2,1 & 2,2 \\
\hline 52 & 1,5 & 1.9 & 2,4 & 1,5 & $2, ?$ & 1,5 & 1.5 & 2,1 & 1,7 & $2, \Omega$ & 1,8 & 1,6 \\
\hline 54 & 1,5 & $2, E$ & $1, ?$ & $.1,5^{\circ}$ & $1, ?$ & 1,5 & 2,3 & 2,0 & 2,0 & 1,9 & 2,0 & 2,0 \\
\hline$=5$ & 1,5 & 1,4 & 1,4 & l, & 1,4 & 1,7 & $I, \epsilon$ & 1,6 & 1,9 & 2,4 & 2.7 & 2.4 \\
\hline $5 E$ & 1,8 & 2,4 & 2,5 & 7,8 & 1,5 & 2,2 & 2,1 & 3,1 & 2,8 & 3,5 & 3,6 & 2,8 \\
\hline 57 & 1,0 & 2,0 & 1,6 & 1,8 & 1.5 & 1,5 & 1.7 & 2,0 & 2,2 & 2,2 & 2.3 & 2,4 \\
\hline 50 & $?, ?$ & 1.7 & 2,4 & 1,4 & 1.5 & 1.7 & 1,0 & 2.2 & 2,4 & $?, ?$ & $2, ?$ & 1,9 \\
\hline 50 & 7,0 & 7.0 & 2,1 & 7,5 & $I, \epsilon$ & 1,6 & 1,8 & 2,0 & $?, \hat{8}$ & 2,6 & 2,6 & 2,4 \\
\hline 1960 & 1.0 & $I, E$ & 1,0 & 1,6 & 1,3 & 1.6 & 1,6 & 2.4 & 2.6 & 2,8 & 3.5 & $?, 5$ \\
\hline$\theta$ & 8.3 & 8.1 & 2.7 & 1,4 & $1,=$ & 1,2 & 1,4 & 2,5 & 1,9 & $2,=$ & 2,4 & 2,2 \\
\hline$f=$ & 2,6 & 1,7 & 1,6 & 1,5 & 1,8 & 2,8 & 1,0 & 0,7 & 1,9 & 1,5 & 1,8 & I, 4 \\
\hline$t=$ & 0,0 & 2,4 & 1.7 & 1,4 & $1, f$ & 2,8 & 1,9 & 1,7 & 2,0 & 2,5 & 1,8 & $z, t$ \\
\hline$E L$ & 2,2 & 0,9 & 0,9 & 1.4 & 2.7 & 2,4 & 1,2 & 2,2 & 2,5 & 2,7 & 3.1 & 2,6 \\
\hline 6 & 3.0 & 2, & $\therefore$ & 2.7 & $2, c$ & $\therefore=$ & $?, 7$ & 2.1 & 2,0 & $?, 9$ & $2=$ & 2,5 \\
\hline 5 & $\therefore, \equiv$ & $\because \because$ & $\therefore 4$ & $\therefore=$ & $\therefore, \vdots$ & 2.5 & 2,2 & 2,2 & $\therefore, C$ & $\therefore, i$ & $\therefore c$ & 3,5 \\
\hline$\Leftrightarrow$ & $z \Omega$ & $2, ?$ & $2=$ & $\therefore x$ & 1,2 & $z=$ & 3.6 & 4,0 & $4, ?$ & 4,6 & 5,2 & 4,3 \\
\hline$t^{\circ}$ & 2,4 & 2.5 & 3,5 & 4,5 & $2, t$ & $\therefore, ?$ & 3,4 & 3.9 & 2, & $4, t$ & 4,2 & 4.5 \\
\hline 207 & 3,2 & $r:$ & $\therefore .5$ & $\therefore r$ & 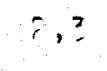 & $\therefore, t$ & $=0$ & 1,9 & 2,2 & 4.0 & 4,6 & 4,7 \\
\hline TOMSI & 50,2 & $\angle 8,0$ & $47, ?$ & $\angle L, 9$ & 40,5 & 44,6 & 45,6 & 52,9 & 61.7 & 67.4 & $6.5,3$ & 61.3 \\
\hline 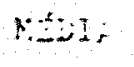 & $=6$ & $\therefore$ & $1,=$ & 2,5 & 2,6 & 2,7 & 1,8 & 2.3 & $?, 2$ & $\therefore 7$ & $\tau, t$ & 2,4 \\
\hline
\end{tabular}

\section{Fontes:}

Posto Agrometeorológico situado a $22^{\circ} 4230^{\prime \prime s}$ e $47^{\circ} 38^{\circ} 00^{\prime \prime} \mathrm{W}, 646 \mathrm{~m}$. altutude Departamento de Fisica e Meteorologia da ESALQUSP - Piracicaba 
Tabela 6 - DIREÇÃO DOS VENTOS - NÚMERO DE OCORRENCIAS EM CADA DIREÇÃO ÀS 7 HORAS - PIRACICABA - SP - $1943-1970$

\begin{tabular}{|c|c|c|c|c|c|c|c|c|c|}
\hline \multirow{2}{*}{ MES } & \multicolumn{9}{|c|}{ DIRECAD } \\
\hline & $N$ & $N E$ & $E$ & $\mathrm{SE}$ & 5 & $\mathbf{S W}$ & W & NW & C \\
\hline Janeiro & 116 & 137 & 123 & 74 & 24 & 13 & 28 & 39 & 221 \\
\hline Fevereiro & 88 & 127 & 158 & 61 & 16 & 13 & 13 & 22 & 208 \\
\hline Março & 45 & 136 & 215 & 88 & 30 & 12 & 18 & 10 & 214 \\
\hline Abril & 21 & 85 & 201 & 108 & 30 & 16 & 23 & 9 & 243 \\
\hline Maio & 19 & 112 & 223 & 51 & 31 & 27 & 18 & 7 & 283 \\
\hline Junho & 22 & 127 & 268 & 30 & 28 & 14 & 12 & 9 & 229 \\
\hline Julho & 26 & 125 & 242 & 47 & 22 & 22 & 16 & 6 & 269 \\
\hline Agosto & 31 & 131 & 238 & 82 & 38 & 28 & 26 & 11 & 185 \\
\hline Setembro & 41 & 130 & 215 & 105 & 45 & 21 & 29 & 12 & 148 \\
\hline Qutubro & 70 & 133 & 175 & 120 & 49 & 37 & 26 & 15 & 149 \\
\hline Novembro & 85 & 109 & 134 & 138 & 46 & 27 & 38 & 29 & 144 \\
\hline Dezembro & 93 & 118 & 135 & 110 & 26 & 14 & 21 & 36 & 137 \\
\hline TOTAL & 657 & 1470 & 2327 & 1014 & 385 & 244 & 268 & 205 & 2430 \\
\hline MÉDIA & 54,7 & 122,5 & 193,9 & 84,5 & 32,1 & 20,3 & 22,3 & 17,1 & 202,5 \\
\hline
\end{tabular}

\section{Fontes:}

Posto Agrometeorologico situado a $22^{\circ} 42^{\prime} 30^{\prime \prime} \mathrm{s}$ e $47^{\circ} 38^{\circ} 00^{\prime \prime} \mathrm{W}, 646 \mathrm{~m}$. altitude Departamento de Fisica e Meteorologia da ESALQJUSP - Piracicaba 


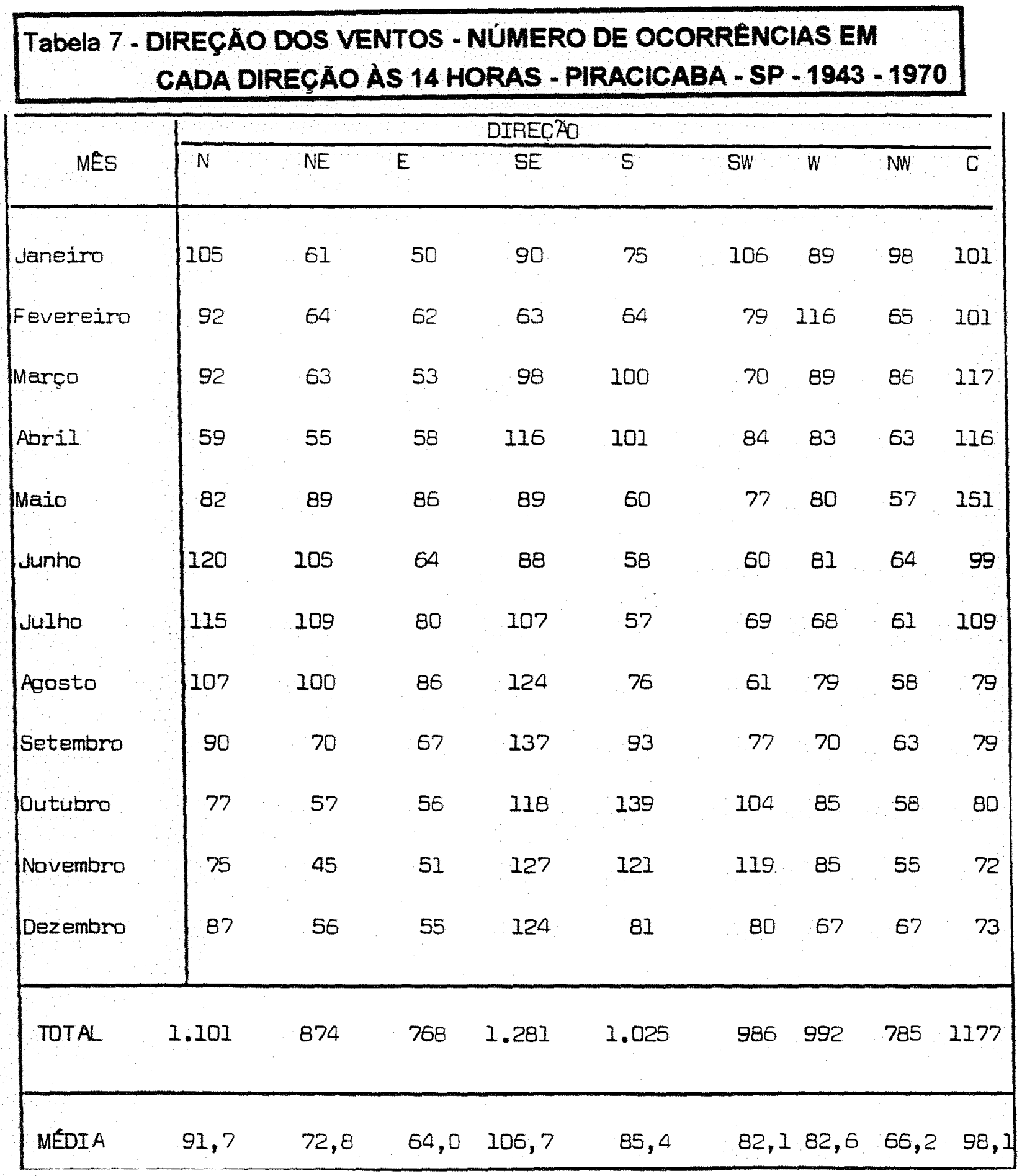

\section{Fontes:}

Posto Agrometeorológico situado a $22^{\circ} 42^{\prime} 30^{\prime \prime} \mathrm{S}$ a $47^{\circ} 38^{\prime} 00^{\mathrm{m}} \mathrm{W}, 546 \mathrm{~m}$. altitude Departamento de Fisica o Meteorologia da ESALQUSP - Piracicaba 


\section{Tabela 8 - DIREÇAOO DOS VENTOS - NÚMERO DE OCORRENCIAS EM CADA DIREÇÃO ÀS 21 HORAS - PIRACICABA - SP - 1943 - 1970}

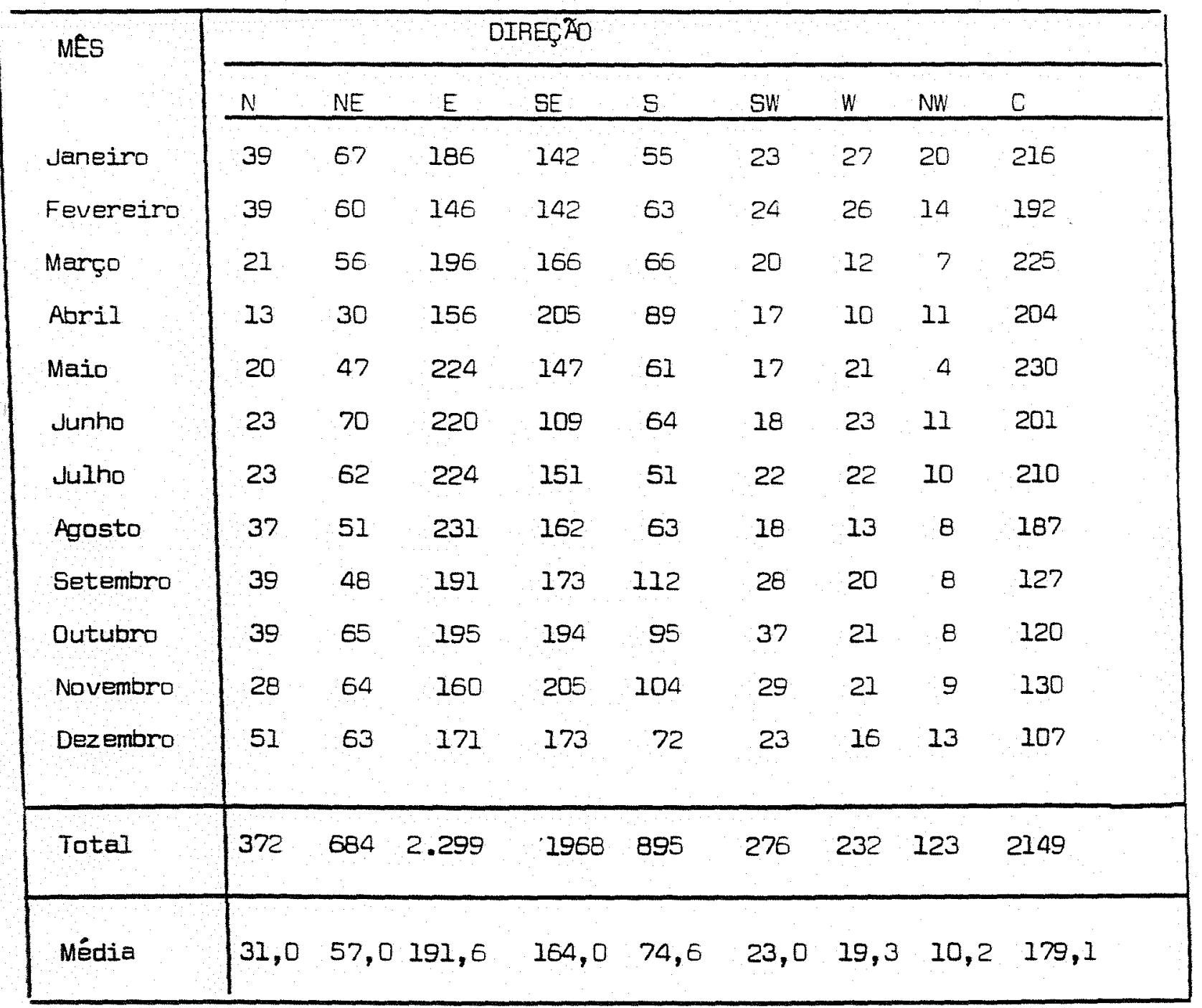

Fontes:

Posto Agrometeorologico situado a $22^{\circ} 42^{\prime} 30^{\prime \prime} \mathrm{s}$ e $47^{\circ} 38^{\circ} 00^{\prime \prime} \mathrm{W}, 646 \mathrm{~m}$. alttude Departamento de Fisica e Meteorologia da ESALQUSP - Piracicaba 


\subsubsection{Hidrologia}

A Estação Ecológica de Ibicatu está situada, na sua totalidade, dentro dos limites de abrangéncia da bacia hidrográfica do Ribeirâo da Jibóia, afluente da margem direita do Rio Tietê, onde desemboca próximo ao distrito de Anhumas. A bacia hidrográfica do Ribeirão da Jiboila situa-se entre as coordenadas $22^{\circ} 45^{\prime}$ e $22^{\circ} 53^{\prime} S$ e os meridianos $47^{\circ} 45^{\prime}$ e $47^{\circ} 58^{\prime}$.

Com uma extensăo aproximada de 32 quilometros, desde sua nascente mais distante da foz, o Ribeirão Jibóia possui uma declividade média em torno de $3 \mathrm{~m} / \mathrm{km}$, isto é, uma declividade que não permite uma alta velocidade de escoamento das águas.

A partir de uma análise preliminar, pelo que se observou em campo, por imagem de satélite e fotografias aéreas, percebe-se que, em geral, a maior parte da área de abrangéncia desta bacia hidrográfica foi desprovida de sua cobertura vegetal original, dando lugar a campos de pastagem e atividades agricolas, principalmente o plantio de cana-de-açúcar. Desta forma, com poucas exceçōes, as nascentes que contribuem para o Ribeirão Jibóia são atualmente de fluxo intermitente, secando em periodos de estiagem, ou mesmo em curtos periodos em que não há chuvas. Observa-se ainda a existência de uma grande quantidade de pequenas represas ao longo dos rios da regiāo, que devem funcionar como uma reserva de água para os períodos de estiagem (ALMEIDA, 1992).

De acordo com observaçōes locais efetuadas em novembro de 1992, o Córrego Monte Branco tem suas nascentes situadas entre a Serra da Fortaleza (onde se localiza o ponto culminante do divisor de aguas da bacia hidrográfica do Ribeirăo Jibóia, com $790 \mathrm{~m}$. de altitude), o Monte Branco e a Serra da Floresta, que constituem as principais formaçōes rochosas locais. Ali está situado o fragmento florestal que constitui a Estaçáo Ecológica de Ibicatu. 
A Unidade de Conservaçấo é cortada no sentido norte-sul por dois afluentes do Córrego Monte Branco, sendo que as nascentes de ambos estão situadas fora dos limites da Estação, restando uma pequena área de matas ciliares e, ainda assim, restrita apenas a proximidade de poucas nascentes.

As principais nascentes que contribuem para os dois afluentes do Corrego Monte Branco e atravessam a Estação Ecológica, podem ser identificadas atraves do mapa planialtimétrico do Estado de São Paulo (escala 1:10.000). Elas perfazem um total de $6,7 \mathrm{~km}$, se fossem dispostas linearmente. A rede hidrográfica da região onde se localiza a Estação Ecológica pode ser observada nas Figuras 13,14 e 15, que mostram respectivamente aquela Unidade de Conservaçáo no Contexto da Hidrovia Tieté/Paraná, a rede hidrográfica da macro-região e a sua rede de drenagem natural. 
Figura 13- ESTAÇÃO ECOLOGICA DE IBICATU NO CONTEXTO DA HIDROVIA TIETE/PARANA

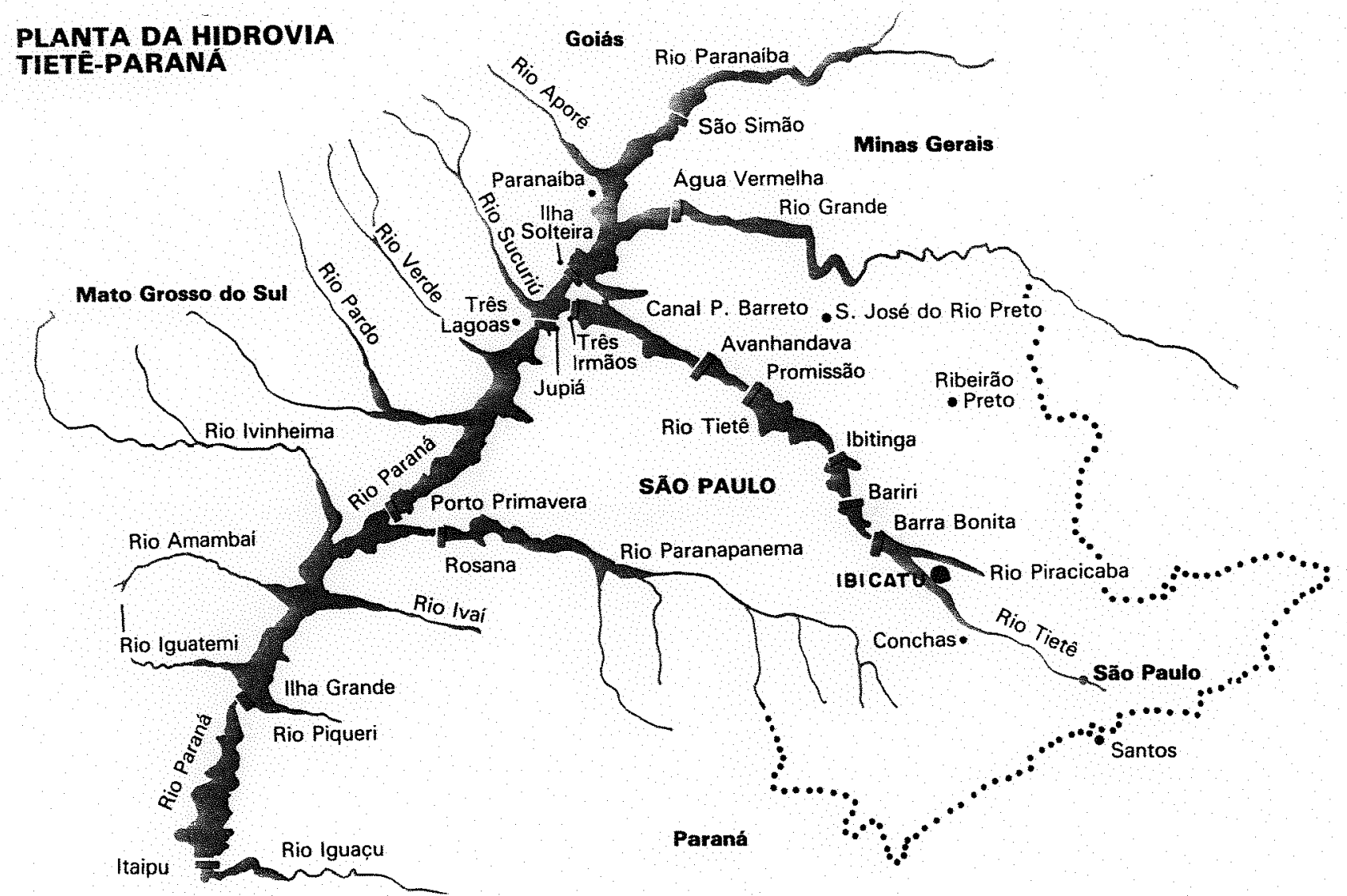

Fonte: Departamento de Águas e energia Elétrica - DAEE - SP (1988) (Situação sem escala) 


\section{Figura 14 - REDE HIDROGRAFICA DA MACRO REGIÁO DA ESTAÇAO ECOLÓGICA DE IBICATU}

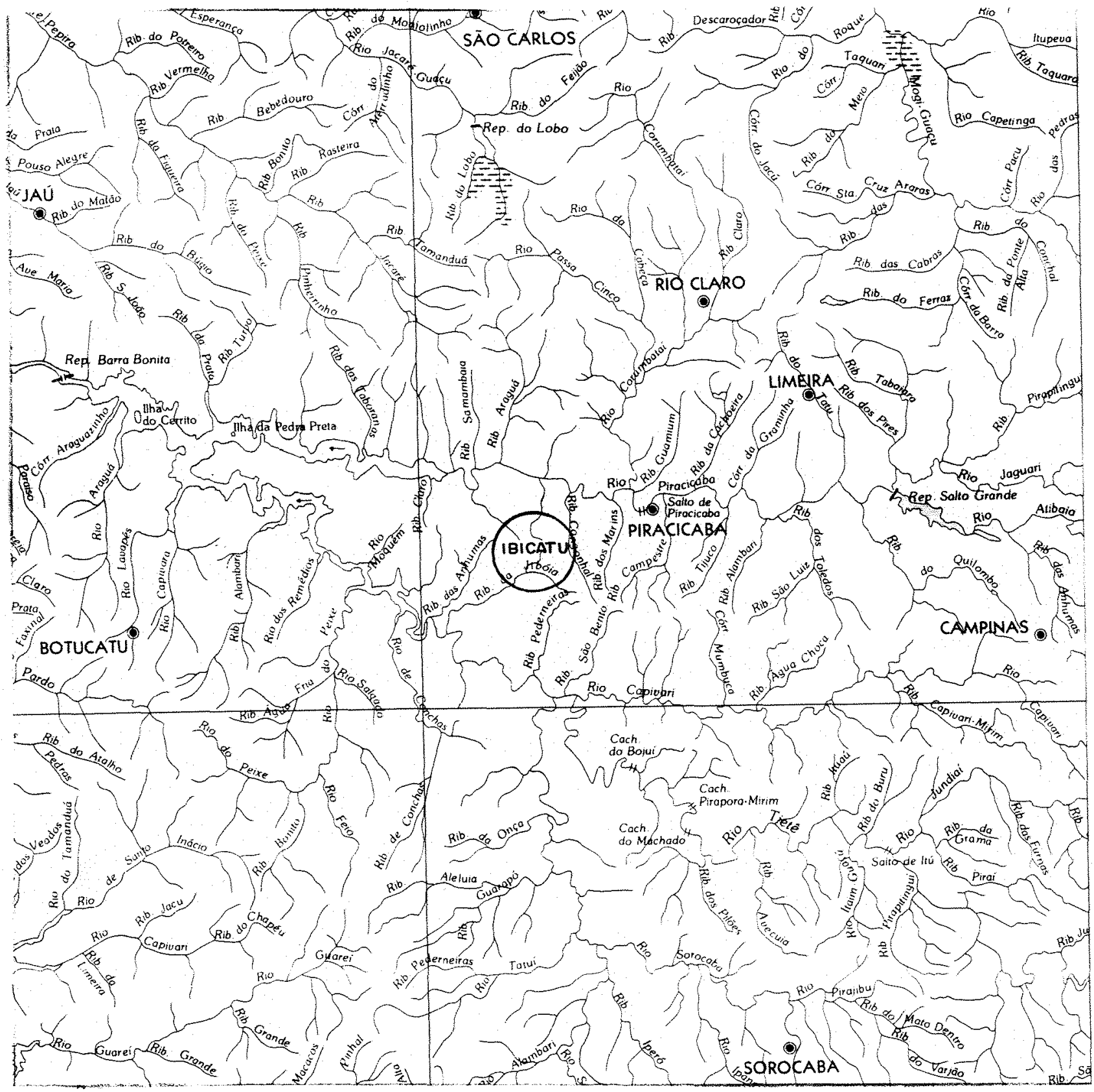


Figura 15 - ESTAÇÃO ECOLÓGICA DE IBICATU

REDE DE DRENAGEM NATURAL

Escala - 1:10.000

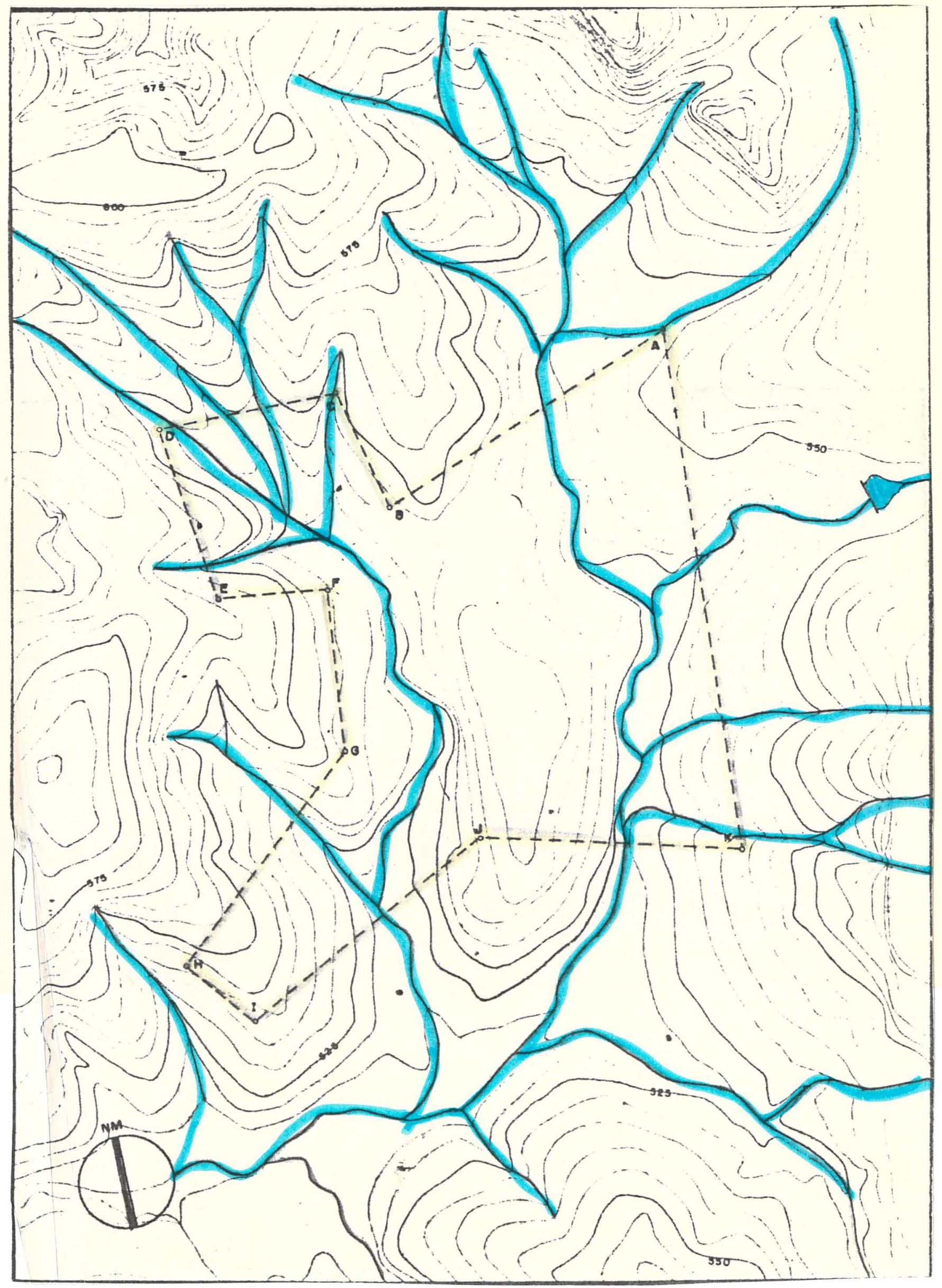




\subsubsection{Vegetação:}

a) Critérios de classificacão fitogeográfica:

De acordo com o Sistema de Classificaçăo Fitogeográfica da Vegetaçăo Brasileira proposto pelo Instituto Brasileiro de Geografia e Estatistica, a vegetaçăo existente na Estação Ecológica de lbicatu deve ser enquadrada na classificaçăo Floresta Estacional Semidecidual (Floresta Tropical Subcaducifólia). O conceito deste tipo de vegetaçáo está condicionado pela dupla estacionalidade climática, uma tropical com época de intensas chuvas de verăo, seguida por estiagem acentuada e outra subtropical sem periodo seco, mas com seca fisiológica provocada pelo intenso frio do inverno, com temperaturas médias inferiores a $15^{\circ} \mathrm{C}$ (IBGE, 1992).

O criterio estabelecido pelo IBGE com a finalidade exclusiva de propiciar o mapeamento continuo de grandes areas foi 0 das faixas altimétricas, como por exemplo: a formaçăo aluvial, está sempre presente nos terraços mais antigos das calhas dos rios; a formaçăo de terras baixas, ocorre entre 5 e 100 metros de altitude entre os $4^{\circ}$ de latitude Norte e os $16^{\circ}$ de latitude Sul, de 5 a $50 \mathrm{~m}$, quando localizados nas latitudes de $16^{\circ}$ a $24^{\circ}$ Sul e de 5 a 30 $\mathrm{m}$. nas latitudes de $24^{\circ}$ a $32^{\circ}$ Sul; a formação sub-montana situa-se numa faixa de 100 a $600 \mathrm{~m}$., de acordo com a latitude de $4^{\circ}$ Norte ate $16^{\circ}$ Sul, de 30 a 400 m. após os $24^{\circ}$ de latitude Sul; e a formação montana, situa-se numa faixa altimetrica, que varia de 600 a $2000 \mathrm{~m}$. de altitude, entre $4^{\circ}$ de latitude Norte e $16^{\circ}$ de latitude Sul, de 500 a $1500 \mathrm{~m}$ entre os $16^{\circ}$ e $24^{\circ}$ de latitude sul e de $24^{\circ}$ a $32^{\circ}$ de latitude sul.

De acordo com esta classificaçăo, a vegetaçăo da Estaçăo Ecológica de Ibicatu pode ser considerada como Floresta Estacional Semidecidual Submontana. Esta formaçăo frequentemente ocorre nas encostas interioranas das Serras da Mantiqueira e dos Órgâos e nos planaltos centrais capeados pelos Arenitos Botucatu, Bauru e Caiuá dos periodos geológicos Jurássico e Cretáceo. 
Ainda segundo o IBGE (1992), sua ocupaçăo vai desde o Espirito Santo e Sul da Bahia até o Rio de Janeiro, Minas Gerais, São Paulo, Norte e Sudoeste do Paraná e Sul do Mato Grosso do Sul. Nas encostas interioranas das serras marítimas, os géneros dominantes com indivíduos caducifolios, săo os mesmos que ocorrem na floresta ombrófila atlantica, como Cedrela, Parapiptdenia e Cariniana, sendo que nos planaltos areníticos os ecótipos deciduais que caracterizam esta formaçăo pertencem aos gêneros Hymenaea (jatobá), Copaifera (6leo-vermelho), Peltophorum (canafistula), Astronium, Tabebuia e muitos outros. Contudo o género dominante que a caracteriza principalmente no Estado de Săo Paulo é Aspidosperma, com seu ecótipo A. polyneuron (peroba-rosa).

\section{b) Caracterizaçăo regional da vegetaçăo}

Segundo EWUSIE (1980), nas regioes tropicais existem algumas florestas situadas em clima com uma ou duas estaçðes secas. Esse tipo é comum no interior do continente. A vegetaçăo se caracteriza pela mistura de espécies deciduas e sempre verdes. Durante o periodo seco, algumas espécies perdem as folhas e florescem. Para este autor, estas florestas apresentam poucas eplifitas e trepadeiras e o sub-bosque é mais exuberante, quando comparado com a floresta tropical úmida.

RIZZINI (1979) afirmou que a floresta mesófila acha-se disseminada abundantemente através da área central do cerrado, sob o mesmo regime climático, em forma de manchas. Entretanto, no Estado de São Paulo, esta formação apresentava-se continua e a sua fragmentaçăo decorreu de açóes antrópicas.

As florestas mesofilas semideciduas são caracteristicamente sazonais com um período de perda de folhas que, em geral, vai de abril a setembro (MORELATTO et al,, 1989). Este periodo corresponde a epoca mais fria e seca do ano, inclusive com a eventual ocorréncia de geadas (PINTO, 1992). Estas florestas são caracteristicamente altas, com individuos emergentes de 20 a 25 metros de altura, com copas sobrepostas. Este tipo de floresta tem 
uma ampla área de ocorréncia no Brasil, desde a regiáo da Serra do Japi até o Norte do Parana, alcançando a Argentina e o Sul do Paraguai de um lado e, de outro lado ocorrendo até Goiás, Minas Gerais e Sul da Bahia (MORELLATO, 1992).

\section{c) Levantamento fitossociológico da Estação Ecológica:}

De acordo com os critérios expostos acima, COSTA (1992) definiu a Estaçăo Ecológica de lbicatu com um trecho de mata mesofila semidecidua e com o objetivo de avaliar qualitativa e quantitativamente a vegetaçăo, amostrou uma área total de $7.600 \mathrm{~m}^{2}$, representativa desta floresta, distribuida em sete transectos, com comprimentos variáveis, perpendiculares à drenagem, distanciados 25 metros entre si e subdivididos em 38 parcelas contiguas de $20 \times 10$ metros. 0 final dos transectos coincidia com área periodicamente inundada pelos cursos d'água existentes no interior da área de estudo. Foram amostrados todos os individuos com circunferencia igual ou maior que $5 \mathrm{~cm}$. do caule na altura do peito (CAP), dos quais estimaram-se as alturas totais. A curva de incremento no número de espécies com o aumento da área amostrada apresentou-se assintótica, indicando que a amostragem foi suficiente para as espécies mais abundantes.

Nas 38 parcelas da área estudada, COSTA (1992) amostrou 3.766 individuos arbóreos (espécies relacionadas em lista anexa), sendo 9 mortos e 260 ramificados abaixo de $1,30 \mathrm{~m}$. de altura. Os 3.757 individuos vivos foram distribuidos por 39 familias, 79 géneros e 103 espécies.

De acordo com MORELLATO (1992) as florestas mesofilas semideciduas têm diversidade floristica alta, com algumas familias caracteristicamente bem representadas - Leguminosae (sensu amplo) Rutaceae, Meliaceae, Euphorbiaceae, Myrtaceae, Rubiaceae e Lauraceae. Estas familias sempre apresentam um consideravel número de espécies e, em todos os estudos florísticos realizados, ocuparam as primeiras posiçőes no que se refere a riqueza especifica e número de individuos. 
Estas afirmaçōes se confirmaram no levantamento efetuado por COSTA (1992) na Estação Ecológica de Ibicatu. As especies vegetais mais abundantes foram Actinostemon concepciones, Angostura pentandra, Metrodorea nigra, Actinostemon concolor e Esenbeckia leiocarpa. As familias com maiores riquezas foram: Leguminosae, Euphorbiaceae, Myrtaceae, Rutaceae e Rubiaceae. A densidade total encontrada foi de $4.943,42$ individuos/hectare e as espécies com maiores IVIs (índices de Valor de Importancia) foram: Esenbeckia leiocarpa, Actinostemon concepciones, Metrodorea nigra, Angostura pentandra e Actinostemon concolor.

Os dados obtidos por COSTA (1992) foram analisados conjuntamente e considerando tres estratos da floresta, estabelecidos a partir das alturas máximas dos individuos. O primeiro estrato foi composto por individuos maiores que 10 metros de altura; o segundo por individuos com mais de $5 \mathrm{~m}$, ate 10 metros e o terceiro estrato por individuos de ate 5 metros de altura.

No primeiro estrato da floresta foram amostrados por este autor 244 individuos $\theta$ as especies com maiores abundáncias foram: Esenbeckia leiocarpa, Securinega guaraiuva, Alchornea triplinervea e Chrysophyllum gonocarpum. As familias com maiores riquezas foram: Leguminosae, Euphorbiaceae e Lauraceae.

No segundo estrato da floresta foram amostrados 707 individuos e as especies com maiores abundâncias foram: Metrodorea nigra, Actinostemon concepciones e Actinostemon concolor. Rutaceae, Myrtaceae, Leguminosae e Euphorbiaceae foram as familias com maiores riquezas.

No terceiro estrato da floresta foram amostrados 2.815 individuos $\theta$ as especies mais abundantes foram: Actinostemon concepciones, Angostura pentandra, Actinostemon concolor e Metrodorea nigra. As familias com maiores riquezas foram: Leguminosae, Myrtaceae, Rutaceae, Rubiaceae e Euphorbiaceae. 
Ao analisar a relação das espécies, COSTA (1992) concluiu que $44,9 \%$ das especies do terceiro estrato e $47 \%$ das especies do segundo são compostas por individuos jovens das espécies do primeiro estrato, confirmando assim a similariedade entre os estratos. Estes resultados sugerem que as espécies do dossel estăo mantendo-se, e a floresta estaria atualmente em equilibrio.

$\mathrm{Na}$ análise dos estratos, COSTA (1992) observou maior diversidade no primeiro e, comparativamente baixa no terceiro, confirmando 0 esperado. Entretanto, as condiçōes do sub-bosque, principalmente de luminosidade, condicionam a existencia de uma flora caracteristica nos estratos inferiores, enriquecida pelas espécies dos estratos superiores, representados por individuos jovens. A classificação sucessional das espécies no estudo de COSTA (1992) indicou $26 \%$ no grupo das pioneiras, $28 \%$ no das secundárias e $46 \%$ no das secundárias tardias/climáticas. A relação das espécies vegetais amostradas na Estaçăo Ecológica de Ibicatu está na Tabela 9. 
Tabela - 9 RELAÇÃO DAS ESPÉCIES VEGETAIS AMOSTRADAS

NA ESTAÇÃO ECOLÓGICA DE IBICATU - PIRACICABA - SP

FAMILIAS

Anacardiaceae

Annonaceae

Apocynaceae

Bignoniaceae

Bombacaceae

Boraginaceae

Caricaceae

Celastraceae

Combretaceae

Compositae

\section{ESPECIES VEOETAIS}

Astronium graveolens Jacq.

Tapinira guianensis Aubl.

Annona cacans War.

Guateria sp.

G. nigrescens Mart.

Aspidosperma cylindrocarpon M. Arg.

A. olivaceum M. Arg.

A. polyneuron M. Arg.

Peschiera fuchsiaefolia Miers.

Jacaranda micrantha Cham.

Tabebuia alba (CHam.) Sandw.

Chorisia speciosa St. Hil.

Cordia ecalyculata Vell.

Carica quercifolia (St. Hil.) Solms.

Jacaratia spinosa (Aubl.) A.DC.

Maytenus alatemoides Reiss.

M. cestritolia Reiss.

Terminalia triflora ( Griseb.) Lillo

Gochnatia polymorpha (Less.) Cabr. 
Tabela 9 - (Continuaçăo)

FAMILIA

Euphorbiaceae

Flacourtiaceae

Icacinaceae

Lauraceae

Lecythidaceae

Leguminosae

\section{ESPÉCIE}

Actinostemon concepciones (Chod. \& Hassl.)

Pax et K. Hoffm.

A. concolor (Spr.) M. Arg.

Alchornea glandulosa Casar.

A. triplinervea (Spreng.) M.Arg.

Croton floribundus Spreng.

Pachystroma longifolium (Nees.)F.M.Johnson

Sebastiana serrata (Baill.) M. Arg.

Securinega guaraiuva Kuhlm.

Casearia sylvestris Sw.

Citronela megaphylla (Miers.) Howard

Endlicheria paniculata (Speg.) Macbr.

Ocotea corymbosa (Meissn.) Mez.

o. lanata (Nees.) Mez.

O. puberula Nees.

O. velloziana (Meissn.) Mez.

Nectandra ambigua Meissn.

Cariniana estrelensis (Raddi.) O. Kuntze

Cariniana legalis (Mart.) O. Kuntze

Acacia polyphylla DC.

Anadenanthera macrocarpa (Vell.) Brenan

Caliiandra tweediei Benth.

Centrolobium tomentosum Guill. ex.Benth

Dalbergia frutescens (Vell.) Britton.

Enterolobium contortisiliquum (Vell.) Morong. 
Tabela 9 - (Continuação)

FAMILIA

\section{ESPÉCIE}

Leguminosae

Holocalix balansae Micheli

Inga edulis Mart.

Lonchocarpus muehibergianus Hassl.

Machaerium nictitans Vog.

M. stipitatum (DC.) Vog.

M. uncinatum (Vell.) Benth.

Pithecelobium ectwallii Hoehne

Pterocarpus rohrii Vahl.

Zollernia ilicifolia (Brong.) Vog.

Malvaceae

Abutilon peltatum K. Schum.

Meliaceae

Trichilia elegans A. Juss.

T. casarettii C. DC.

T. catigua A. Juss.

T. palfida SW.

Monimiaceae

Siparuna apiosyce (Mart.) A. DC.

Moraceae

Cecropia graziou Sneth.

Sorocea bonplandii (Baill.) Burg.

Myrsinaceae

Rapanea umbellata (Mart.) Meiss.

Myrtaceae

Calyptranthes grandiflora Berg.

Campomanesia guaviroba (A.DC.) Kiaersk

C. guazumaefolia (Camb.) Berg.

Eugenia sphenophylla Berg.

E. sulcata Spreng ex. Mart.

Myrciaria floribunda (West. ex. Wild.) Berg.

Siphoneugenia densifiora Berg. 
Tabela 9 - (Continuação)

FAMILIA

Nyctaginaceae

Guapira opposita (Vell.) Reitz.

Neea mollis Spr. ex K. Schum.

Palmae

Arecastrum romanzoffiana (Cham.) Glassman

Phytolaccaceae

Seguiera aculeata Jacq.

S. langsdorffii Mop.

Piperaceae

Piper amalago (Jacq.) Yunker

Proteaceae

Roupala montana Aubl.

Rhamnaceae

Colubrina grandulose Reiss.

Rhamnidium elaeocarpum Reiss.

Rosaceae

Prunus sellowii Koehne

Rubiaceae

Amaioua guianensis Aubl.

Coffea arabica $L$.

Chomelia ribesoides Cham.

Ixora venulasa Benth.

Psychotria cartagenensis Jacq.

$P$. lejocarpa Cham. \& Schlechdt

Rudgea jasminoides (Cham.) M. Arg.

Rutaceae

Angostura pentandra (St. Hil.) Albuquerque

Esenbeckia febrifuga (St. Hil.) A. Juss.

E. leiocarpa Engl.

Metrodorea nigra St. Hil.

Pilocarpus pauciflorus St. Hil. 
Tabela 9 - (Continuacão)

\begin{tabular}{ll}
\hline FAMILIA & ESPECIE \\
Rutaceae & $\begin{array}{l}\text { P. pennatifolius Leem. } \\
\text { Zanthoxylum minutiflorum Tul. }\end{array}$ \\
Sapindaceae & Cupania vernalis Camb. \\
& Matayba guianensis Aubl. \\
Sapotaceae & Chrysophyllum gonocarpum(Mart.\&Eichl.)Engl \\
& C. marginatum Radlk.
\end{tabular}

Simaroubaceae

Solanaceae

UImaceae

Urticaceae

Verbenaceae

Violaceae

Fonte: COSTA, 1992.
Picramnia parvifolia Engl.

Solanum megalochiton Mart.

S. swartzianum Roem. \& Schultz

Celtis iguanaea (Jacq.) Sarg.

Urera baccifera ( L.) Gaud.

Aegiphila sellowiana Cham.

Hybanthus atropurpureus (St.Hil.) Taub. 


\section{d) Observaçōes locais na Unidade de Conservaçăo:}

Foram efetuados diversos levantamentos de campo para observaçăo da formaçăo vegetal ocorrente na area objeto de estudo, percorrendo-se as trilhas existentes com o intuito de melhor conhecer a estrutura da mata para propor medidas de manejo para aquela Unidade de Conservaçăo.

De modo geral, constatou-se que a floresta mesófila estacional semidecidua ocorre de forma continua em quase toda a area da Estaçăo, com exceçăo da pequena área reservada às edificaçóes e de pequenos trechos de pasto sujo, que ocorrem nos limites da mata. A floresta encontra-se em avançado estágio sucessional, principalmente no seu interior. As areas mais próximas as bordas demonstram maior interferéncia devido a descontinuidade do dossel, pois a Estaçăo faz limites com plantaçóes de cana-de-açúcar e pastos (ALMEIDA, 1992).

Atraves de entrevistas com moradores locais, constatou-se que a mata sofreu corte seletivo ao longo do tempo para retirada de madeira e palmito. Alguns individuos de Cariniana sp. (jequitibá) e Aspidosperma sp. (peroba) de grande porte săo remanescentes da floresta primitiva.

Observou-se também que Euterpe edulis (palmito-doce) ocorre nas baixadas proximas aos cursos d'água. Apesar de informaçбes da ocorréncia de extraçóes de palmito no passado, verificou-se significativos agrupamentos desta especie em varios pontos da floresta. Existem ainda locais onde ocorre intensa regeneraçăo desta palmeira, especialmente em areas mais úmidas (Figura 16).

A Euterpe edulis, de acordo com KAGEYAMA (1987) é considerada uma mutualista-chave - planta que fornece suporte critico a grandes complexos de elos moveis e cuja perda poderia levar a perda de elos móveis, seguida pelas perdas de plantas dependentes dos elos, através da ruptura na reprodução e dispersão. Denominam-se elos móveis os animais que 
são fatores significativos na persistência de diversas espécies de plantas que suportam outras cadeias de alimentos separadas.

Conforme foi confirmado também através de entrevistas com habitantes do entorno, a área da Unidade de Conservaçăo já foi, no inicio deste século, cortada por uma estrada utilizada para passagem de carroças e cavalos. Atualmente, há vestigios da antiga via, que se encontra em processo de regeneração com individuos de porte médio no local ocupado no passado pelo seu antigo leito.

Em seu estudo da estrutura e da dinámica de um trecho do fragmento florestal de lbicatu, COSTA (1992) concluiu que ocorrem resultados semelhantes a outros trechos estudados, onde poucas familias e espécies são responsáveis pela estrutura da mata. A ocorréncia de regeneraçăo das espécies do dossel nos estratos inferiores fez este autor sugerir que a floresta se encontra atualmente em equilibrio.

No entanto, na analise efetuada "in loco", shamou a atençăo - elevado númerc de clareiras e a expressiva ocorréncia de moitas de bambu que dominam algumas dessas clareiras, retardando o processo de colonizaçăo de outras especies pioneiras.

Em relaçăo às sindromes de dispersăo, dentre as espécies amostradas por COSTA (1992), $16 \%$ săo autocóricas, $62 \%$ são zoocóricas e $22 \%$ anemocóricas, reforçando a necessidade da proteçăo desta formaçăo florestal. Este resultado confirma as observaçőes de LONGMAN \& JENIK (1974), que relataram a ocorrência de zoocoria na maioria das espécies arbóreas tropicais. Devido à auséncia de outros fragmentos de mata na regiåo mais próxima, sugere-se que a interrelaçăo entre fauna e flora seja muito intensa, havendo forte dependéncia de uma em relaçăo à outra (ALMEIDA, 1992).

E' importante salientar, na análise da vegetaçăo da Estação Ecológica de lbicatu, o aspecto peculiar dos Jequitibás existentes (Cariniana 
Figura 16 - OCORRENCIA DE Euterpe Edulis (MUTUALISTA-CHAVE) NO INTERIOR DA ESTAÇÃO ECOLÓGICA DE IBICATU

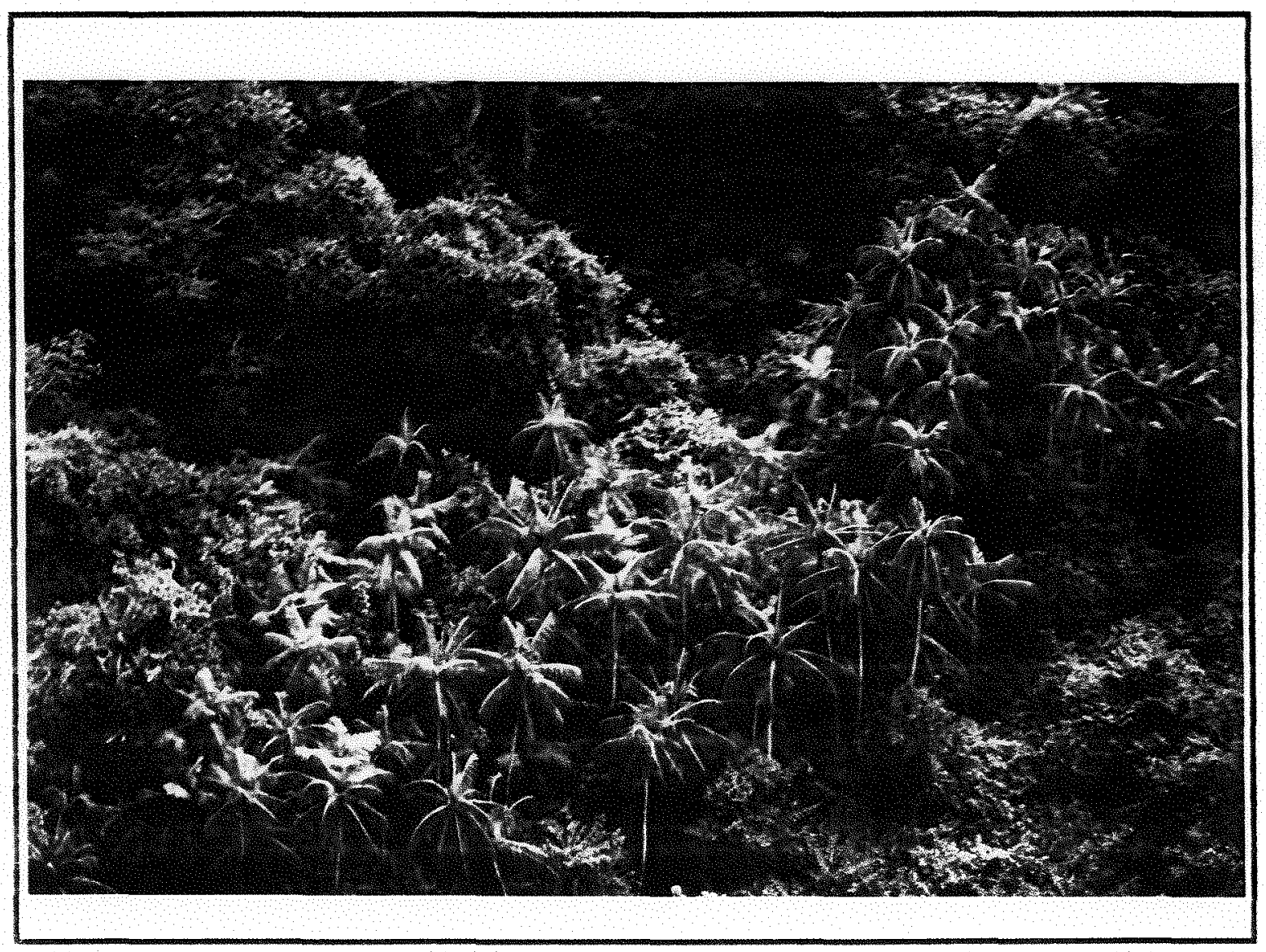


sp.) que se destacam pelas suas elevadas dimensóes, dando um caráter singular à mata e cuja existência pode ser considerada como fator preponderante no processo de aquisição e conservaçáo daquela Unidade de Conservação pelo poder público.

\subsubsection{Fauna:}

Foi efetuado levantamento preliminar da fauna da Estação Ecologica de lbicatu de 31/10/92 a 03/11/92, por um grupo de estudantes da disciplina "Estrutura e Manejo de Unidades de Conservaçāo", do Curso de PósGraduação em Ciência Ambiental, da Universidade de São Paulo, sob a orientação do Professor Álvaro Fernando de Almeida (ALMEIDA, 1992). Foram verificados dados qualitativos em relaçăo à herpetofauna, avifauna e mastofauna. Informaçסes quantitativas puderam ser obtidas nos casos onde se realizaram capturas de animais. Os métodos utilizados foram:

*observaçăo direta - feitas através de caminhadas no interior das trilhas existentes na Estaçăo Ecológica de lbicatu, a olho nu, ou utilizando-se binóculos (com as seguintes caracteristicas de $08 \times 30$ ou $10 \times 50$ ), quando necessário.

*observaçăo indireta - com base na gravaçăo em campo e identificaçăo posterior das vocalizações das aves.

* captura de animais - A captura de mamiferos foi realizada através da colocaçăo de $\mathbf{2 3}$ armadilhas de arame galvanizado, tipo americano, com as seguintes caracteristicas: 11 armadilhas pequenas, de múltipla captura e 12 armadilhas médias de captura simples. Elas foram distribuidas ao longo das trilhas, em locais estratégicos da área objeto de estudo, como por exemplo, margens dos riachos, locais com caracteristicas de abrigos para os animais ("tocas") e proximidade de árvores frutiferas. Como iscas para os animais foram utilizados os seguintes produtos: milho ou laranja com pasta de amendoim e pescoço de galinha fresco. As verificaçóes de captura de animais foram efetuadas no periodo da manhă, durante trés dias consecutivos. A captura de aves foi realizada através da colocação de 12 redes neblina (mist nets), de malha de 12 m.de comprimento e $2,8 \mathrm{~m}$. de altura, colocadas em pontos estratégicos da Unidade de 
Conservação, armadas antes do dia clarear, permanecendo abertas por um periodo de quatro horas e sofrendo checagens irregulares durante este tempo. No final da tarde, as redes eram novamente armadas, permanecendo cerca de duas horas até o escurecer.

* entrevistas com moradores da regiâo - Foram realizadas também entrevistas com moradores da região, de forma a obter informaçōes complementares sobre a fauna local. O depoimento mais importante neste contexto foi o do senhor João Gomes de Almeida, que durante 32 anos foi guarda-florestal da Estação Ecológica, tendo-se aposentado no inicio de 1992.

a) Mastofauna:

Os exemplares da mastofauna encontrados na Estação Ecologica de ibicatu e identificados com base em EMMONS (1991) constam na Tabela 10. 


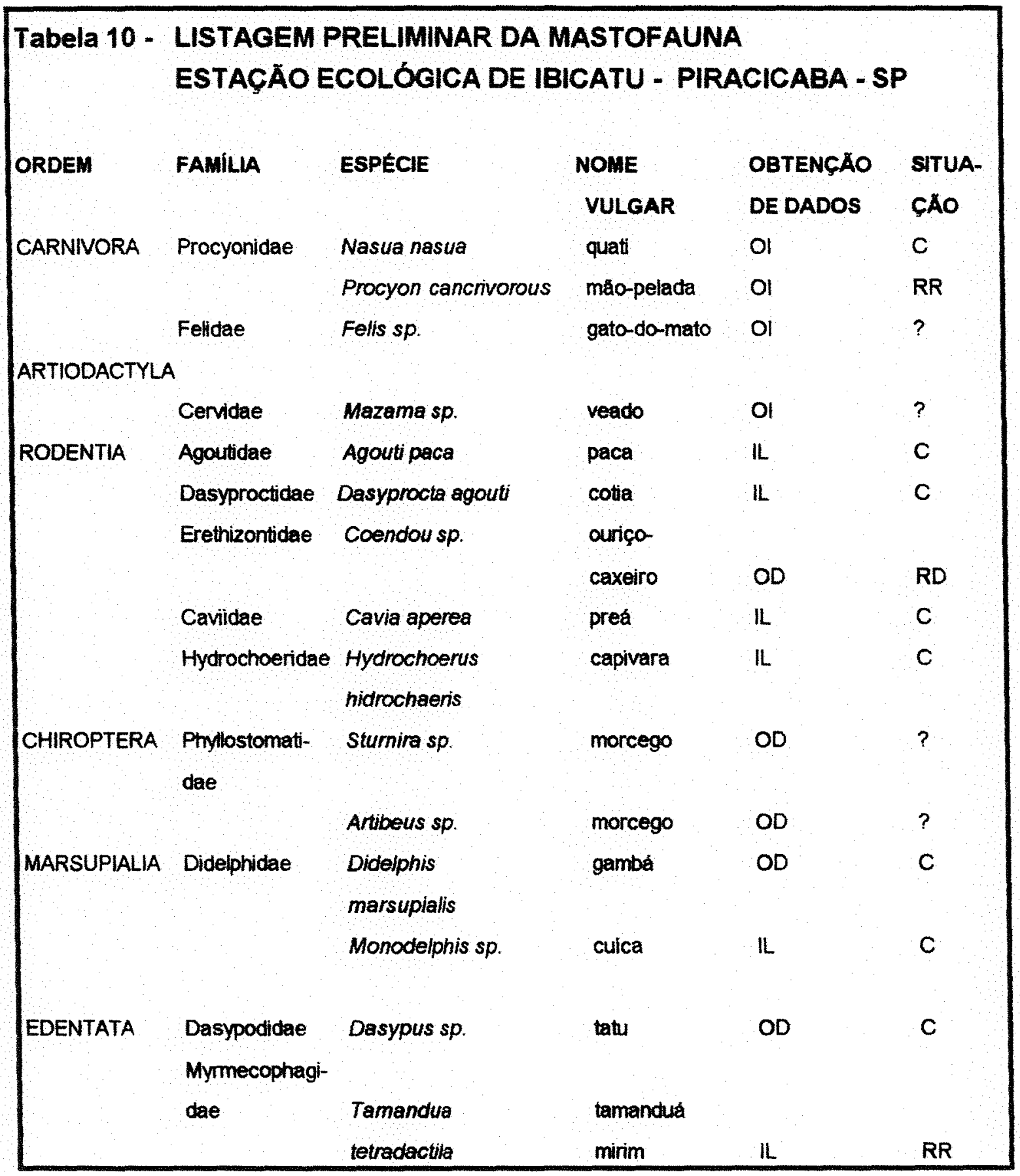


Tabela 10 - (Continuação)

\begin{tabular}{|c|c|c|c|c|c|}
\hline ORDEH & FAMILIA & ESPÉCIE & NOME & OBTENCAO & SITUA- \\
\hline & & & VULGAR & DE DADOS & CAOO \\
\hline EDENTATA & Bradypodidae & Bradypus sp. & preguiça & IL & RR \\
\hline \multirow[t]{2}{*}{ PRIMATA } & Cebidae & Cebus apella & macaco-prego & Ol & C \\
\hline & Callithricidae & Callithrix aurita & sagai & $O D$ & $R R$ \\
\hline
\end{tabular}

Legenda:

Forma de obtenção de dados

$O D=$ observaçăo direta

Ol = observaçăo indireta

IL = informação local

\section{Situação conservacionista}

$C=$ comum

$\mathrm{RD}=$ espécie com população reduzida

$\mathbf{R} \mathbf{R}$ = especie rara

$?=$ s/dados da espécie 
b) Avifauna:

A identificação das aves foi realizada com base em bibliografia especifica (SICK, 1985, FRISCH, 1981, DE SCHAUENSEE, 1970, DE SCHAUENSEE et alli., 1978, HILTHY \& BROWN, 1986 e NAROSKY \& YZURIETA, 1987). Verificou-se a ocorrência das seguintes espécies, relacionadas na Tabela 11. 


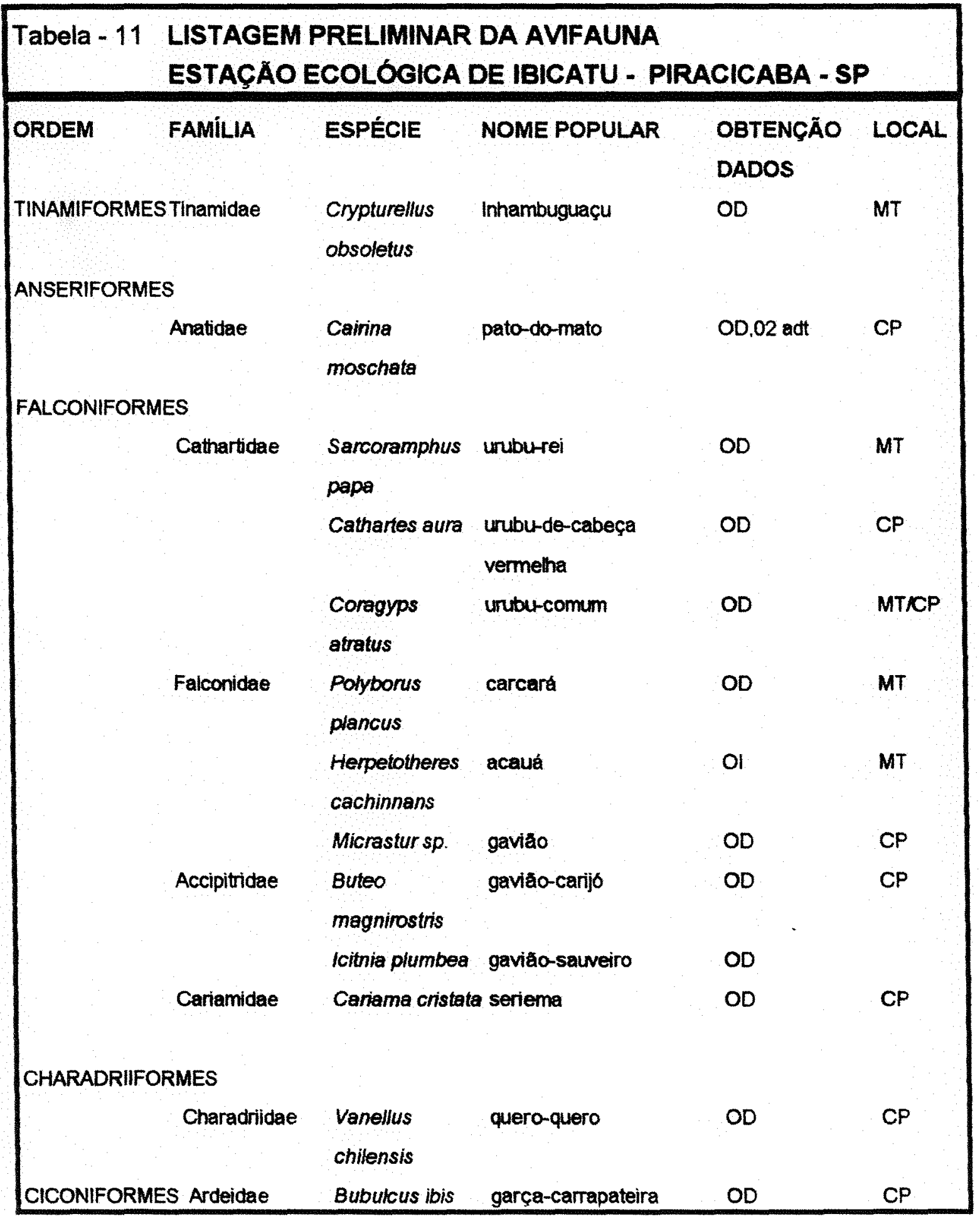


Tabela 11 - continuaçăo

\begin{tabular}{|c|c|c|c|c|c|}
\hline \multirow[t]{2}{*}{ ORDEM } & FAMÍLIA & ESPÉCIE & NOME VULGAR & $\begin{array}{l}\text { OBTENGÃO } \\
\text { DADOS }\end{array}$ & LOCAL \\
\hline & & $\begin{array}{l}\text { Syrigma } \\
\text { sibilatrix }\end{array}$ & maria-faceira & $O D, m \& f$ & $\mathrm{CP}$ \\
\hline \multicolumn{6}{|c|}{ PSITACIFORMES } \\
\hline & Psittacidae & $\begin{array}{l}\text { Aratinga } \\
\text { leucophtalmus }\end{array}$ & maracană malhada & $O D$ & MT \\
\hline & & $\begin{array}{l}\text { Pionus } \\
\text { maximiliani }\end{array}$ & maitaca & $O D$ & MT \\
\hline & & $\begin{array}{l}\text { Forpus } \\
\text { xanthopterygius }\end{array}$ & tum & $O D$ & \\
\hline \multicolumn{6}{|c|}{ CUCULIFORMES } \\
\hline & Cuculidae & Guira guira & anu branco & $O D$ & $\mathrm{CP}$ \\
\hline & & Piaya cayana & alma-de-gato & $O D$ & MT \\
\hline & & Crotophaga ani & anu preto & $O D$ & $\mathrm{CP}$ \\
\hline \multicolumn{6}{|c|}{ STRIGIFORMES } \\
\hline & Strigidae & $\begin{array}{l}\text { Athene } \\
\text { cunicularia }\end{array}$ & $\begin{array}{l}\text { coruja- } \\
\text { buraqueira }\end{array}$ & $O D$ & $\mathrm{CP}$ \\
\hline \multicolumn{6}{|c|}{ COLUMBIFORMES } \\
\hline & Columbidae & Leptotila sp & juriti & $O D, f$ & MT \\
\hline & & $\begin{array}{l}\text { Columbina } \\
\text { talpacoti }\end{array}$ & rolinha roxa & CT & $B M$ \\
\hline & & $\begin{array}{l}\text { Geotrygon } \\
\text { violacea }\end{array}$ & jurti-piranga & CT, 1 & $\mathrm{BM}$ \\
\hline \multicolumn{6}{|c|}{ APODIFORMES } \\
\hline & Trochilidae & $\begin{array}{l}\text { Eupetomena } \\
\text { macroura }\end{array}$ & tesoura & $\mathrm{OB}$ & $\mathrm{CP}$ \\
\hline & & $\begin{array}{l}\text { Chiorastilbon } \\
\text { aureoventris }\end{array}$ & $\begin{array}{l}\text { besourinho-de } \\
\text { bico-vermelho }\end{array}$ & $\mathrm{CT}$ & \\
\hline
\end{tabular}


Tabela - 11 (Continuacăo)

\begin{tabular}{|c|c|c|c|c|}
\hline ORDEM & FAMÍLIA & ESPÉCIE & NOME VULGAR & $\begin{array}{l}\text { OBTENÇÄO } \\
\text { DE DADOS }\end{array}$ \\
\hline \multicolumn{5}{|c|}{ CORACIFORMES } \\
\hline & Alcedinidae & $\begin{array}{l}\text { Chloroceryle } \\
\text { amencana }\end{array}$ & martim-pescador & $\mathrm{CT}, \mathrm{f}$ \\
\hline \multicolumn{5}{|c|}{ PICIFORMES } \\
\hline & Ramphastidae & $\begin{array}{l}\text { Ramphastos } \\
\text { toco }\end{array}$ & tucanuçu & $O D$ \\
\hline & Picidae & $\begin{array}{l}\text { Colaptes } \\
\text { campestris }\end{array}$ & $\begin{array}{l}\text { pica-paut } \\
\text { do-campo }\end{array}$ & $O D$ \\
\hline \multicolumn{5}{|c|}{ TROGONIFORMES } \\
\hline & Trogonidae & Trogon rutus & surucua amarelo & OD \\
\hline \multicolumn{5}{|c|}{ PASSERIFORMES } \\
\hline & Dendrocolapti- & Lepidocolaptes & & \\
\hline & dae & $\begin{array}{l}\text { tuscus } \\
\text { Lepidocolaptes }\end{array}$ & arapaçu rajado & CT \\
\hline & & $\begin{array}{l}\text { squamatus } \\
\text { Dendrocolaptes }\end{array}$ & arapaçu escamoso & CT \\
\hline & & $\begin{array}{l}\text { platyrostris } \\
\text { sittasomus }\end{array}$ & arapaçu grande & ст \\
\hline & & griseicapillus & arapaçu verde & CT \\
\hline & Furnarildae & $\begin{array}{l}\text { synallaxis } \\
\text { ruficapilla }\end{array}$ & pichororé & $O D$ \\
\hline & & $\begin{array}{l}\text { Synallaxis } \\
\text { trontalis }\end{array}$ & petrim/crispim & Ст \\
\hline & & $\begin{array}{l}\text { Synallaxis } \\
\text { spixi }\end{array}$ & joăo tenenem & $O D$ \\
\hline & & $\begin{array}{l}\text { Phacellodomus } \\
\text { ruber }\end{array}$ & carrega-pau-grande & CT \\
\hline
\end{tabular}


Tabela - 11 (Continuaçăo)

\begin{tabular}{|c|c|c|c|c|c|}
\hline \multirow[t]{18}{*}{ ORDEM } & FAMILIA & ESPECIE & NOME VULGAR & $\begin{array}{l}\text { OBTENÇAO } \\
\text { DE DADOS }\end{array}$ & LOCAL \\
\hline & Furnariidae & & & & \\
\hline & & $\begin{array}{l}\text { Lochmias } \\
\text { nematura }\end{array}$ & capitāo-porcaria & $O D$ & \\
\hline & Formicaridae & $\begin{array}{l}\text { Conopophaga } \\
\text { lineata }\end{array}$ & Chupa-dente & $C P, m \& f$ & $\mathrm{BM}$ \\
\hline & & $\begin{array}{l}\text { Dysithamnus } \\
\text { mentalis }\end{array}$ & Choquinha lisa & $C P, m \& f$ & MT \\
\hline & & $\begin{array}{l}\text { Thamnophilus } \\
\text { caerulescens }\end{array}$ & choca-da-mata & $\mathrm{CP}, \mathrm{m}$ & MT \\
\hline & & $\begin{array}{l}\text { Mymeciza } \\
\text { toricata }\end{array}$ & $\begin{array}{l}\text { papa-formiga } \\
\text { assobiador }\end{array}$ & $O D$ & MT \\
\hline & Tyrannidae & $\begin{array}{l}\text { Platyrinchus } \\
\text { mystaceos }\end{array}$ & patinho & $C P, O D$ & MT \\
\hline & & Colonia colonus & viuvinha & $O D$ & MT \\
\hline & & Attila rutus & capitao-de-saira & $O D$ & \\
\hline & & Hemitriccus sp. & relogio & $O D$ & MT \\
\hline & & $\begin{array}{l}\text { Camptostoma } \\
\text { obsoletum }\end{array}$ & risadinha & $O D$ & \\
\hline & & $\begin{array}{l}\text { Conthopis } \\
\text { delalandi }\end{array}$ & formigueiro & CT & \\
\hline & & $\begin{array}{l}\text { Empidonax } \\
\text { eulen }\end{array}$ & $\begin{array}{l}\text { papa-mosca } \\
\text { pardo }\end{array}$ & CT & $\mathrm{BM}$ \\
\hline & & $\begin{array}{l}\text { Myiarchus } \\
\text { ferox }\end{array}$ & $\begin{array}{l}\text { maria-cava- } \\
\text { leira }\end{array}$ & CT & \\
\hline & Troglodytidae & $\begin{array}{l}\text { Myiarchus sp. } \\
\text { Troglodites }\end{array}$ & - & $O D$ & $\mathrm{CP}$ \\
\hline & & aedon & corruira & $O D$ & $\mathrm{CP}$ \\
\hline & Turdidae & $\begin{array}{l}\text { Turdus } \\
\text { seucomelas }\end{array}$ & sabiá-branco & $\mathrm{CT}$ & $M T / B M$ \\
\hline
\end{tabular}


Tabela - 11 (Continuação)

\begin{tabular}{|c|c|c|c|c|c|}
\hline \multirow[t]{20}{*}{ ORDEM } & FAMILIA & ESPECIE & NOME VULGAR & $\begin{array}{l}\text { OBTENÇÃO } \\
\text { DE DADOS }\end{array}$ & LOCAL \\
\hline & Vireonidae & Vireo & & & \\
\hline & & olivaceus & juruviara & $O D$ & MT \\
\hline & & $\begin{array}{l}\text { Cyclarhis } \\
\text { gujanensis }\end{array}$ & gente-de-fora-vem & $O D$ & MT \\
\hline & Thraupidae & $\begin{array}{l}\text { Ramphocelus } \\
\text { bresilius }\end{array}$ & tié-sangue & $O D$ & MT \\
\hline & & Ramphocelus sp & tié & $O D$ & MT \\
\hline & & Thraupis sayaca & sanhaço-cinzento & $O D$ & MT \\
\hline & & Tangara cayana & saira velha & $O D$ & MT \\
\hline & & $\begin{array}{l}\text { Thichothraupis } \\
\text { melanops }\end{array}$ & tie-de-espelho & ODICT, $f$ & \\
\hline & & $\begin{array}{l}\text { Tachyphonus } \\
\text { rufus }\end{array}$ & tié & $O D, m \&$ & \\
\hline & & $\begin{array}{l}\text { Tachyphonus } \\
\text { coronatus }\end{array}$ & tié-preto & $C T, m$ & $M T$ \\
\hline & & Habia rubica & tié-da-mata & $\mathrm{CT}, \mathrm{m}$ & MR \\
\hline & & $\begin{array}{l}\text { Thiypopsis } \\
\text { sordida }\end{array}$ & saira-canário & OD & \\
\hline & Fringilidae & $\begin{array}{l}\text { Onyzoborus } \\
\text { angolensis }\end{array}$ & curió & OD/CT, $f$ & \\
\hline & & $\begin{array}{l}\text { Zonotrichia } \\
\text { capensis }\end{array}$ & tico-tico & $O D$ & $\mathrm{CP}$ \\
\hline & & Coryphospingus & & & \\
\hline & & cucculatus & tico-tico-rei & $O D$ & \\
\hline & & Sporophila sp. & caboclinho & $O D$ & \\
\hline & Parulidae & $\begin{array}{l}\text { Basileuterus } \\
\text { hypoleucus }\end{array}$ & $\begin{array}{l}\text { mariquita-de } \\
\text { peito-branco }\end{array}$ & CT & MT \\
\hline & Pipridae & $\begin{array}{l}\text { Manacus } \\
\text { manacus }\end{array}$ & rendeira & $C T, f$ & MT \\
\hline
\end{tabular}


Tabela - 11 (Continuacão)

\begin{tabular}{|c|c|c|c|c|c|}
\hline \multirow[t]{4}{*}{ ORDEM } & FAMILIA & NOME & NOME & OBTENÇÃO & SITUAÇÄO \\
\hline & & CIENTÍFICO & VULGAR & DADOS & \\
\hline & Hirundinidae & $\begin{array}{l}\text { Notiochelidon } \\
\text { cyanoleuca }\end{array}$ & $\begin{array}{l}\text { andorinha azul } \\
\text { e branca }\end{array}$ & $O D$ & $\mathrm{CP}$ \\
\hline & Motacillidae & Anthus sp. & caminheiro & $O D$ & \\
\hline \multirow[t]{2}{*}{ Total: } & \multicolumn{5}{|c|}{47 espécies observadas } \\
\hline & \multicolumn{5}{|c|}{25 espécies capturadas $=$ total 72} \\
\hline
\end{tabular}

Legenda:

1) Forma de obtenção dos dados:

2) Local:

$O D=$ observação direta

MT = mata

OI = observação indireta

BM = borda da mata

$\mathrm{CT}=$ captura em redes

$M R=$ mata

$\mathrm{m}=$ macho

$\mathrm{CP}=$ campo

$f=$ fêmea 
c) Herpetofauna:

O levantamento da herpetofauna existente na Estação Ecológica de lbicatu foi obtido somente com base em observaçóes diretas obtidas ao acaso. A identificação baseou-se em SANTOS, 1981, CAPULA, 1989, A listagem preliminar da herpetofauna esta na Tabela 12 :

\begin{tabular}{|c|c|c|c|}
\hline \multicolumn{4}{|c|}{$\begin{array}{r}\text { Tabela } 12 \text { - LISTAGEM PRELIMINAR DA HERPETOFAUNA NA } \\
\text { ESTAÇÃO ECOLOGICA DE IBICATU - PIRACICABA }\end{array}$} \\
\hline FAMILIA & NOME CIENTIFICO & NOME VULGAR & $\begin{array}{l}\text { LOCAL DE } \\
\text { OBSERVAÇÃO }\end{array}$ \\
\hline Boidae & Boa constrictor & jibóia & mata \\
\hline Colubridae & Spilotes pullatus & caninana & $\begin{array}{l}\text { galho de árvore, } \\
\text { na beira de rio } \\
\text { na mata }\end{array}$ \\
\hline
\end{tabular}

\section{d) Consideracōes gerais:}

No levantamento preliminar efetuado na Estação Ecológica de lbicatu observou-se espécies generalistas e oportunistas, como o gambá (Didelphiis marsupialis) estão presentes em relativa abundância, (foram capturados nas armadilhas quatro individuos em quatro dias de trabalho de campo), enquanto que frugivoros tipicos estão ausentes. Isto pode indicar a existência de uma desorganização na cadeia alimentar, na medida em que a fauna de alimentação mais especializada é substituida pela de hábitos onivoros e generalistas. 
Observa-se também na Estação Ecológica de Ibicatu a ocorrencia de animais facilmente adaptados a ambientes secundários como o arapaçu (Sittasomus griseicapillus) e da fauna sinantropa, como a andorinha Notiochelidon sp., a rolinha Columbina sp. e a corruíra Troglodites aedon. Já a avifauna tipicamente neotropical, como os contingideos e os tucanos (SICK, 1985) estão muito pouco presentes ou ausentes (ALMEIDA, 1992).

A Unidade de Conservação de Ibicatu apresenta alguns habitantes dignos de nota como os animais considerados raros ou ameaçados de extinçăo, como pato-do-mato e o curio. A reserva é hoje um refúgio para estes animais e ainda funciona como provável área de caça para o magnífico urubu-rei (Sarcoramphus papa) que foi observado sobrevoando a região. Esta ave tem sofrido uma drástica redução populacional no Sudeste brasileiro, pois depende de extensas áreas florestadas para a sobrevivencia, tendo sido apontada como indicador ecologico (SILVA, 1992b).

Com o objetivo de aprofundar o conhecimento sobre a fauna existente na Estação Ecológica de lbicatu estava prevista a realização de outros levantamentos complementares, que entretanto não puderam ser realizados, devido a impossibilidade de se obter a autorização oficial por parte do Instituto Florestal para se prosseguir nestes trabalhos.

\subsubsection{Paisagem local: visuais cênicas}

\section{a) Considerações gerais:}

A paisagem, definida por Bertrand, citado por PELLEGRINO (1986) e a resultante de tres componentes principais: o potencial abiótico, a exploração biótica e a utilização antrópica, interferindo nos dois primeiros. Neste contexto, DELPOUX (1974) coloca que todos os casos concretos de paisagem podem ser divididos em duas unidades elementares: 0 suporte, que apresenta determinadas caracteristicas (forma, cor, textura), resultantes de influéncias geologicas, climáticas e antrópicas e a sua cobertura, que materializa as influências climáticas, pedológicas e antrópicas (usos 
humanos, presentes e passados, reflexos de atividades sócio-econômicas e culturais).

A avaliação da paisagem é feita fundamentalmente pela observação, pois segundo o National Forest Landscape Management (ESTADOS UNIDOS, 1973), $87 \%$ da percepção humana estão baseados no sentido da visão. Assim, para que a paisagem seja agradável ao ser humano, é preciso que os elementos observados estejam bem visíveis e individualizados, devendo, no entanto, ser harmónicos no seu conjunto. Portanto, uma intervenção numa Unidade de Conservação exige que os efeitos visuais mantenham ou aumentem o grau do bem estar psicológico do homem.

Neste contexto, a beleza da paisagem natural provem da harmonia dos elementos que a compóem. Ela difere das outras formas de arte, puramente estéticas, pelo seu carater dinámico em funçăo das mudanças do tempo, como o período do dia, condições meteorológicas, estaçóes climáticas, etc. $E^{\prime}$ importante lembrar que as mudanças ocorridas na vegetação, devido aos ciclos biológicos das espécies vegetais, fazem com que a floresta se transforme com o passar do tempo. Assim, observa-se o crescimento das plantas, e as suas variações fenológicas durante o transcorrer das estações do ano, como florescimento, frutificação, queda de folhas, mudanças de tons, etc. Esta condição de paisagem efémera torna-se ainda mais importante no caso das florestas estacionais semideciduais, como a de lbicatu, onde estas alterações são facilmente visualizadas.

O estudo da paisagem na Estação Ecológica de Ibicatu foi efetuado em função da abrangência da escala trabalhada. Assim, vários cenários locais sofreram múltiplas influências, de natureza antropogênica ou natural, num processo dinámico e acumulativo, que devem ser considerados em um contexto holístico.

b) Análise da paisagem da Estacăo Ecológica de Ibicatu: 
A determinação da paisagem local identifica dois caracteres

distintos:

Macro-paisagem: Representada pela impressão global da floresta, definindo um ambiente unificado, que pode ser observado com um único golpe de vista. No caso da floresta de Ibicatu, a principal paisagem panorámica identificada é exclusivamente a partir das vias de acesso, em função das peculiaridades do relevo local. Entende-se por paisagem panoramica aquela em que os objetos em primeiro e segundo plano năo bloqueiam substancialmente a vista dos objetos em último plano. (LITTON, 1968). Esta paisagem combina os seguintes fatores visuais: céu, vegetação e solo, observada em termos de forma, linha, cor e textura.

Micro-paisagem: $E^{\prime}$ aquela que apresenta visibilidade restrita a uma pequena distáncia, vista de uma só vez, de qualquer ponto vantajoso. São as mais significativas em lbicatu e encontram-se classificadas , segundo LITTON, da seguinte forma:

- paisagem de destaque: e aquela representada por um ou mais objetos destacados. E' o caso dos grandes jequitibas (Cariniana spp.) existentes no interior da floresta, cuja magnitude faz com que as formas circundantes fiquem sensivelmente subordinados a eles. Outro exemplo săo as concentraçôes de palmito-doce (Euterpe edulis), considerados outro importante marco visual na paisagem local.

- paisagem focal: $E^{\prime}$ aquela localizada num ponto convergente do relevo. $E^{\prime}$ encontrada em lbicatu nas calhas dos cursos d'água, muitas vezes enfatizadas por um destaque no final, representada por uma pequena cascata. Verifica-se tambem este tipo de paisagem em alguns pontos das trilhas que cortam a floresta.

- paisagem coberta: Caracteriza-se por um grupo de elementos situados imediatamente acima do observador, como a cobertura da copa das árvores. Esta paisagem, que se carateriza pelas rápidas mudanças de luz e sombra, e o principal tipo de paisagem verificado no interior da floresta de Ibicatu. 
- paisagem de detaihe: $E^{\prime}$ ligada imediatamente ao primeiro plano. Ocorre quando se observa minúsculos segmentos da floresta ou planos do solo, objetos individuais ou partes de objetos. Estas paisagens são sempre encontradas no interior de lbicatu por um observador atento e sensivel aos pequenos detalhes.

\subsection{Mobiliário existente:}

A única edificação existente na Estação Ecologica de lbicatu no primeiro semestre de 1994 , é uma pequena casa de alvenaria, atualmente desabitada, com as seguintes dependencias, sala, dois quartos, sanitario e cozinha (Figura 17). O sistema construtivo fol efetuado com o emprego de tijolos de barro, revestidos de argamassa, e cobertura com telhas de barro. Esta casa não está servida por rede de energia luz elétrica, nem dispóe atualmente de sistema de abastecimento de água, apesar da existência de instalaçōes hidraulicas, que inclui reservatorio de fibro-cimento. $O$ sistema de captação de agua, encontra-se abandonado e consta de uma pequena barragem, e ruinas do local onde estava instalado uma pequena bomba manual.

As cercas divisórias da Unidade de Conservação, executadas com o emprego de mourōes de madeira e fios de arame farpado, quando existem, estão em péssimas condiçôes de manutenção, não cumprindo a sua finalidade de proteger a floresta de invasóes do gado que pastoreia no seu entorno.

Os aceiros, que circundavam todo o perimetro da Unidade de Conservação e funcionavam como verdadeiros "caminhos", utilizados antigamente para fiscalização do local, encontram-se atualmente sem nenhuma manutenção. No passado, eles serviam para proteger a floresta contra o fogo, facilitar a circulação no seu entorno e para delimitar efetivamente suas divisas. As pontes ali existentes nas calhas do relevo estão completamente destruidas, impedindo a passagem nestes locais. 
Figura 17 - RESIDÉNCIA EXISTENTE NA ESTAÇÃO ECOLÓGICA DE IBICATU ATUALMENTE FECHADA

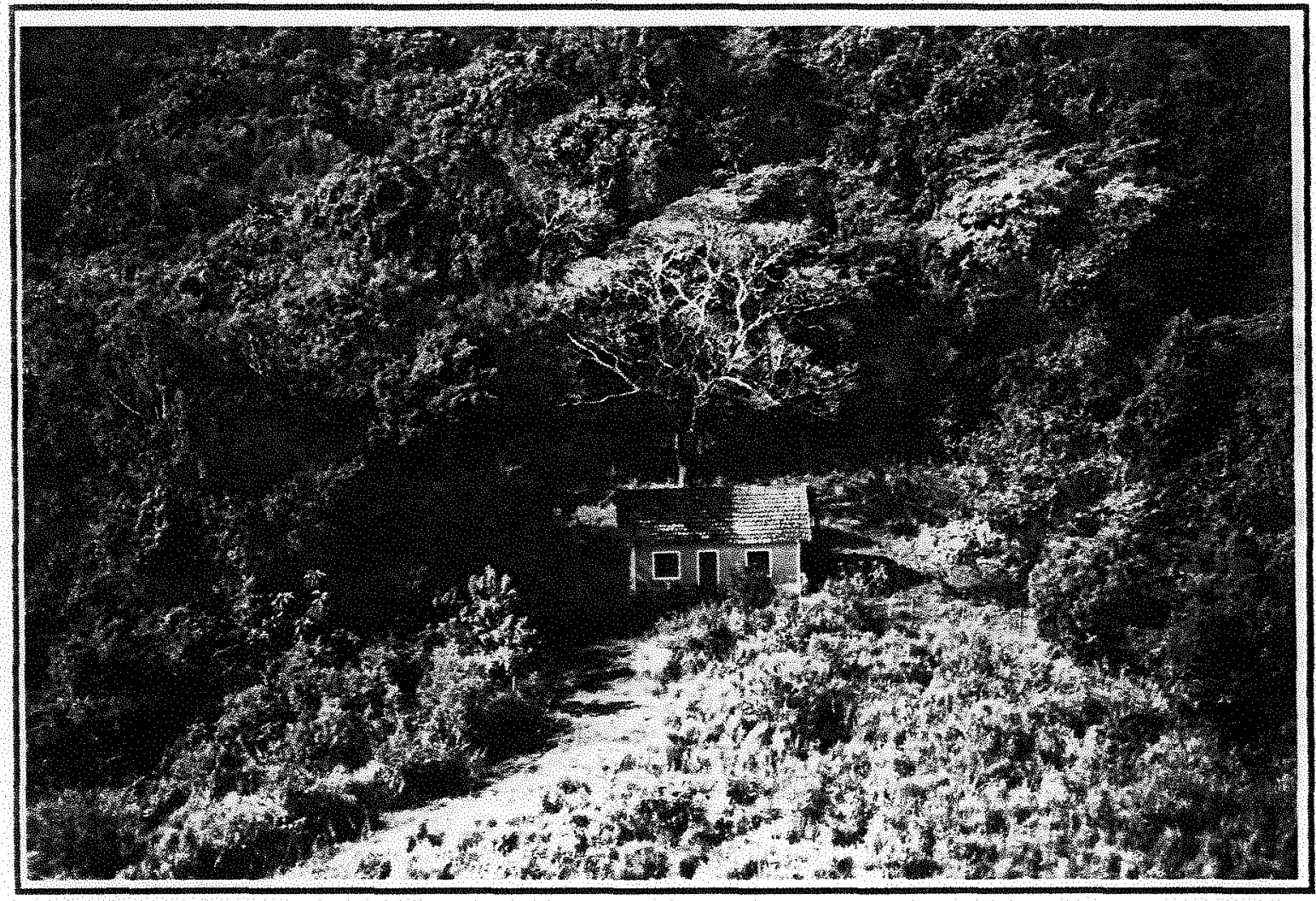




\subsection{Estudos de deriva ambiental na Unidade de Conservação}

\subsubsection{Aspectos gerais:}

O processo de desenvolvimento observado nos municípios da região, especialmente em Piracicaba, pode comprometer a perfeita manutenção da integridade da Estação Ecológica de Ibicatu. A pressão sobre a área só tende a se agravar no futuro. $E^{\prime}$ representada pelo crescimento populacional das cidades mais próximas, pelo aumento das facilidades de acesso ao local, com a pavimentação das estradas existentes no seu entorno, e pelo maior conhecimento sobre as peculiaridades únicas e beleza cénica da floresta de lbicatu que a comunidade vem obtendo através dos diversos meios de comunicação.

A estes fatores, se somam as dificuldades para a administração da área, a cargo do Instituto Florestal, que não tem conseguido efetuar os serviços necessários a manutenção daquela Unidade de Conservação, tais como vigilancia, medidas de proteçăo contra o fogo, invasōes e a observação do cumprimento da legislação pertinente.

Por outro lado, verifica-se a grande expansão da cultura da cana-de-açúcar, que pelo seu atual sistema de produçăo influencia decisivamente na degradação ambiental, prejudicando o solo, a qualidade das águas e do ar e destruindo a biota.

Para BERRIOS (1993), a agricultura da cana pouco se adaptou aos novos requerimentos ambientais. Continua como responsável por violentos impactos ao sistema solo, pela erosão, perda de fertilidade e da sua vida orgánica; as águas, a causa da poluição por materiais erodidos e defensivos agricolas; a atmosfera, a poluição derivada das queimas, e a biosfera, ao serem eliminados organismos úteis para o solo e cobertura vegetal. Assim, para este autor, por tais motivos, a monocultura canavieira continua sendo uma prática problemática, com resistência a orientaçóes que objetivam tratamentos mais condignos com a natureza.

Esta exploraçăo agricola intensiva que utiliza máquinas e equipamentos pesados no processo de produção e transporte está gerando uma 
compactação excessiva dos solos. As matas ciliares e os pequenos fragmentos florestais, com as queimadas constantes dos canaviais também estão sendo paulatinamente destruidos. Esta situação traz como conseqüência uma diminuição no reabastecimento do lençol freático, reduzindo a vazão média dos cursos d'água. A este fato soma-se o efeito negativo das cargas poluidoras originárias do emprego de herbicidas e maturadores químicos utilizados no cultivo da cana.

Por outro lado, VIANA (1990) constata que resultados preliminares de pesquisa em andamento realizada na Escola Superior de Agricultura "Luiz de Queiroz" -ESALQ - no Estado de São Paulo, indicam uma pronunciada diferença na estrutura de fragmentos circundados por plantações de cana-de-açúcar, em comparação com fragmentos circundados por áreas de reflorestamento. Nos fragmentos circundados por plantios de cana foi observado: (I) uma maior incidencia de fogo, (II) maior frequéncia de queda de arvores nas bordas, (III) maior ocorrencia de cipós e (IV) maior intensidade de perturbaçóes antrópicas do que nos fragmentos circundados por reflorestamento.

Além disso, verifica-se a frequente ocorrência de processos erosivos, que não podem ser controlados, apesar da construção de terraços. Isto ocorre, porque o plantio da cana geralmente coincide com o periodo das chuvas. Nesta epoca, o solo se encontra desprotegido, pois foi retirada a cobertura vegetal existente, atraves de araçôes profundas, que rompem a sua estrutura e facilitam a remoção de suas partículas e o arrastamento pelas encostas, em direção aos cursos d'água.

Para BERRIOS (1993), através de uma estimativa empregando-se uma das fórmulas trabalhadas pelos pesquisadores Resende \& Almeida, conhecida como método de Wischmeir ou USLE, obteve-se numa hipótese em que as condições são altamente favoráveis para a erosão, a estimativa de que se perderia anualmente 70.03 toneladas por hectare sob cultivo de cana Numa hipotese mais conservadora, esse valor cairia para 37,72 toneladas por ano. 
As enxurradas que provocam a erosão vão causando, ao longo do tempo, deposições deste solo em pontos baixos ao longo dos corpos d'água, provocando 0 seu assoreamento, matando a vegetação arbórea existente, pelo excesso de umidade e criando condições para a proliferação excessiva de plantas rasteiras e arbustivas.

Outro problema grave são as queimadas, que destróem a vida nas primeiras camadas do solo, prejudicando suas caracteristicas físicoquímicas e formando uma crosta dura e impermeável, que prejudica a oxigenação e a infiltração de água. Alem do fogo representar uma grande ameaça pelo perigo de invasão em areas vizinhas, causando incêndios descontrolados, a fumaça, gases, cinzas e fuligem provocam poluiçăo atmosférica.

A qualidade da água também fica afetada pelo uso constante de substancias químicas, com o emprego de herbicidas utilizados para eliminar as ervas daninhas, que podem ser carreados ate os cursos d'água.

\subsubsection{Análise da situação local:}

A Estação Ecológica de Ibicatu apresenta diversos problemas de degradação ambiental e riscos a sua perfeita manutenção, a saber:

a) Conservação inadequada do solo das propriedades vizinhas, onde se manifestam processos erosivos, de forma mais ou menos acentuada, conforme pode ser verificado nas fotos seguintes.

b) Plantio de cana-de-açúcar em areas contiguas à Unidade de Conservação, tornando-a vulnerável aos problemas decorrentes dessa cultura, já mencionados, a serem observados na aproximação das vistas aéreas nas fotos seguintes.

c) A proteção inadequada dos cursos d'água e suas nascentes ocasionou o carreamento do solo erodido para o interior da Estação. Assim, formaram-se 
Figura 18 - APROXIMAÇĀO AEREA MOSTRANDO O CULTIVO DE CANADE-AÇÚCAR EM ÁREA VIZINHA À ESTACCAOO ECOLÓGICA DE IBICATU (1)

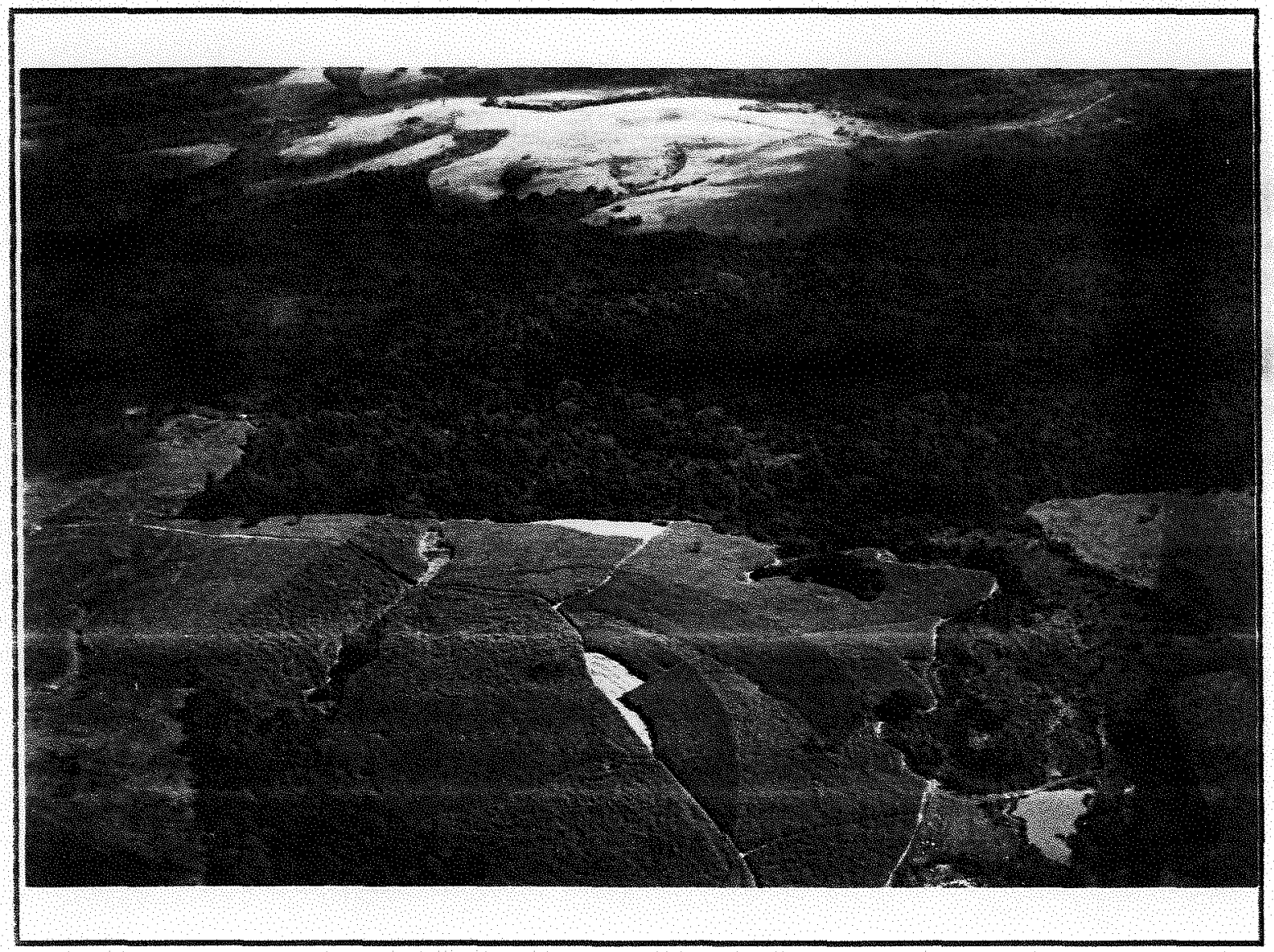


Figura 19 - APROXIMAÇÃO AÉREA MOSTRANDO O CULTIVO DE CANADE-AÇÚCAR EM AREA VIZINHA À ESTAÇÃO ECOLÓGICA DE IBICATU (2)

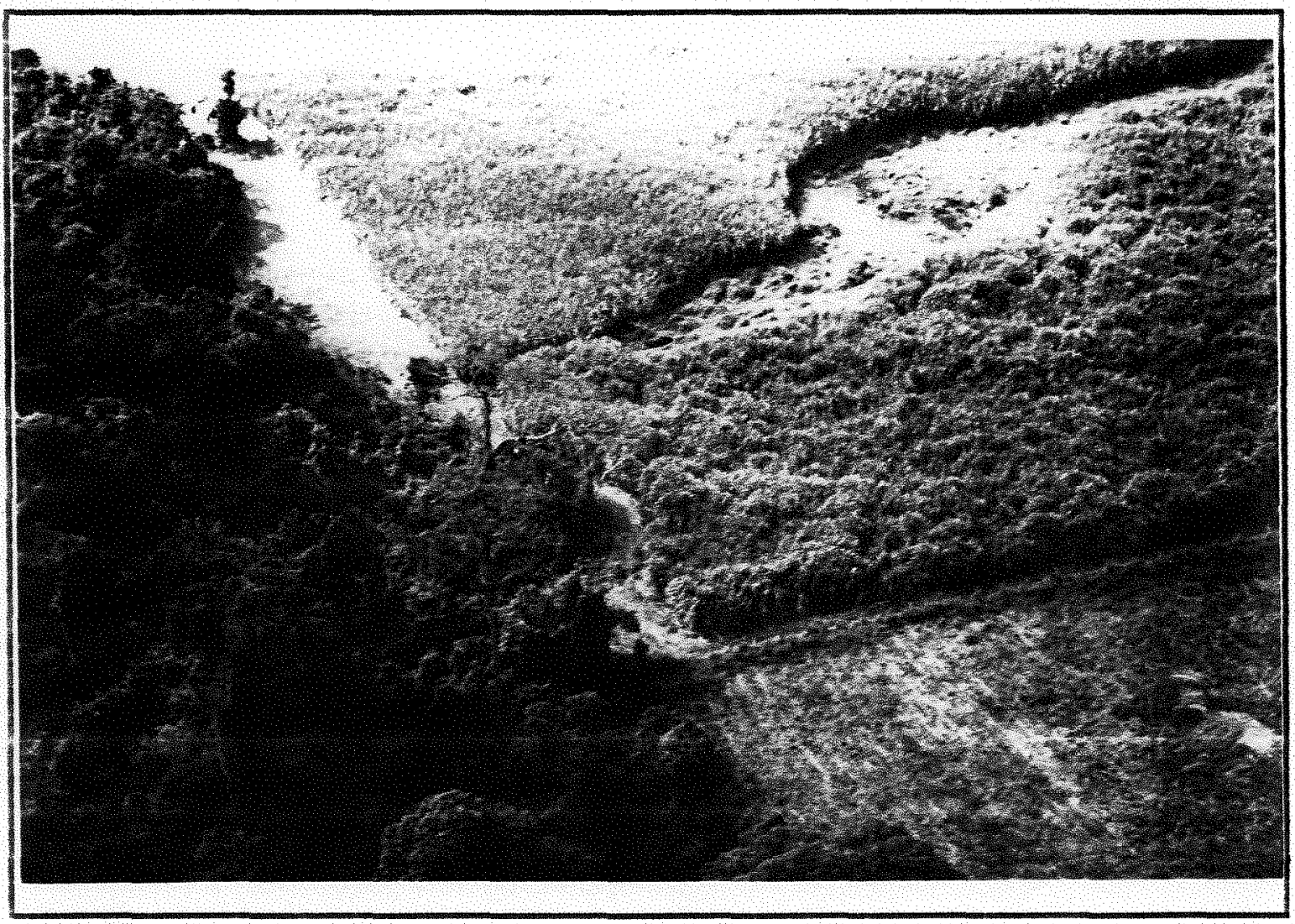


Figura 20 - PLANTIO DE CANA-DE-AÇUCAR NO ENTORNO DA ESTAÇÃO ECOLOGICA DE IBICATU

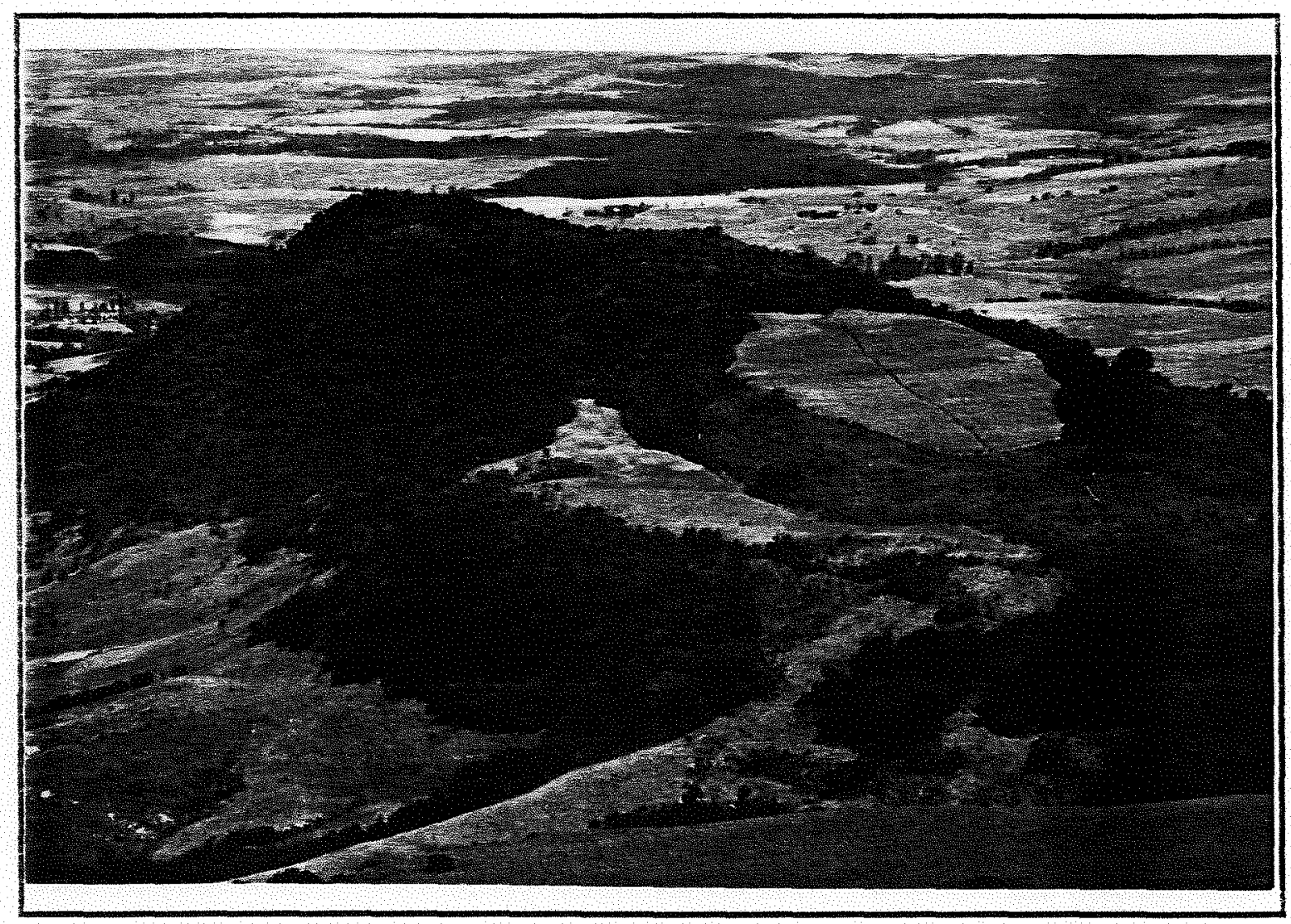


Figura 21 - ÁREA DEGRADADA NO INTERIOR DA FLORESTA EM DECORRENNCIA DO AUMENTO EXCESSIVO DE ÁGUA RETIDA NO LOCAL

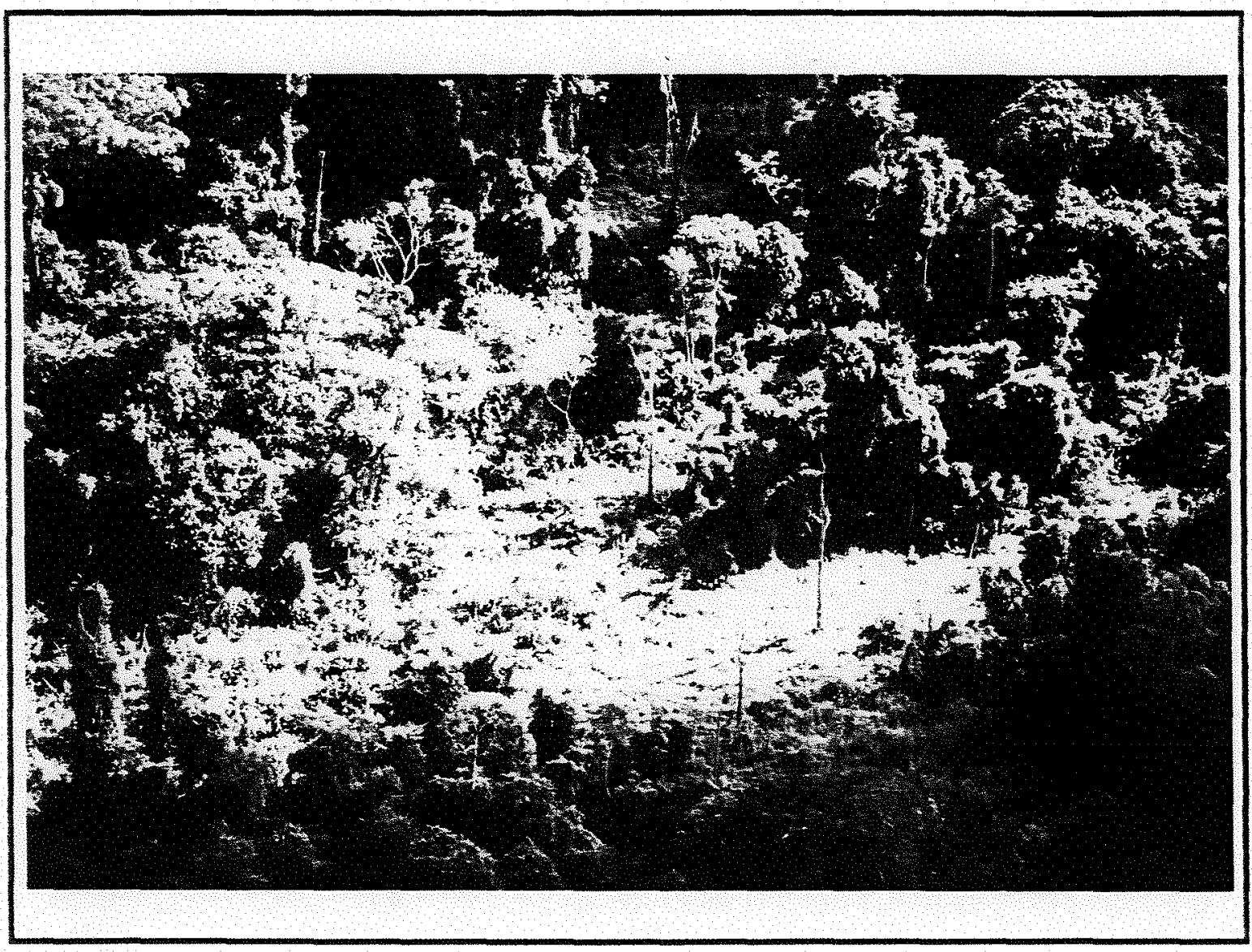


Figura 22 - CLAREIRA OBSERVADA NO INTERIOR DA FLORESTA DA ESTAÇAO ECOLÓGICA DE IBICATU

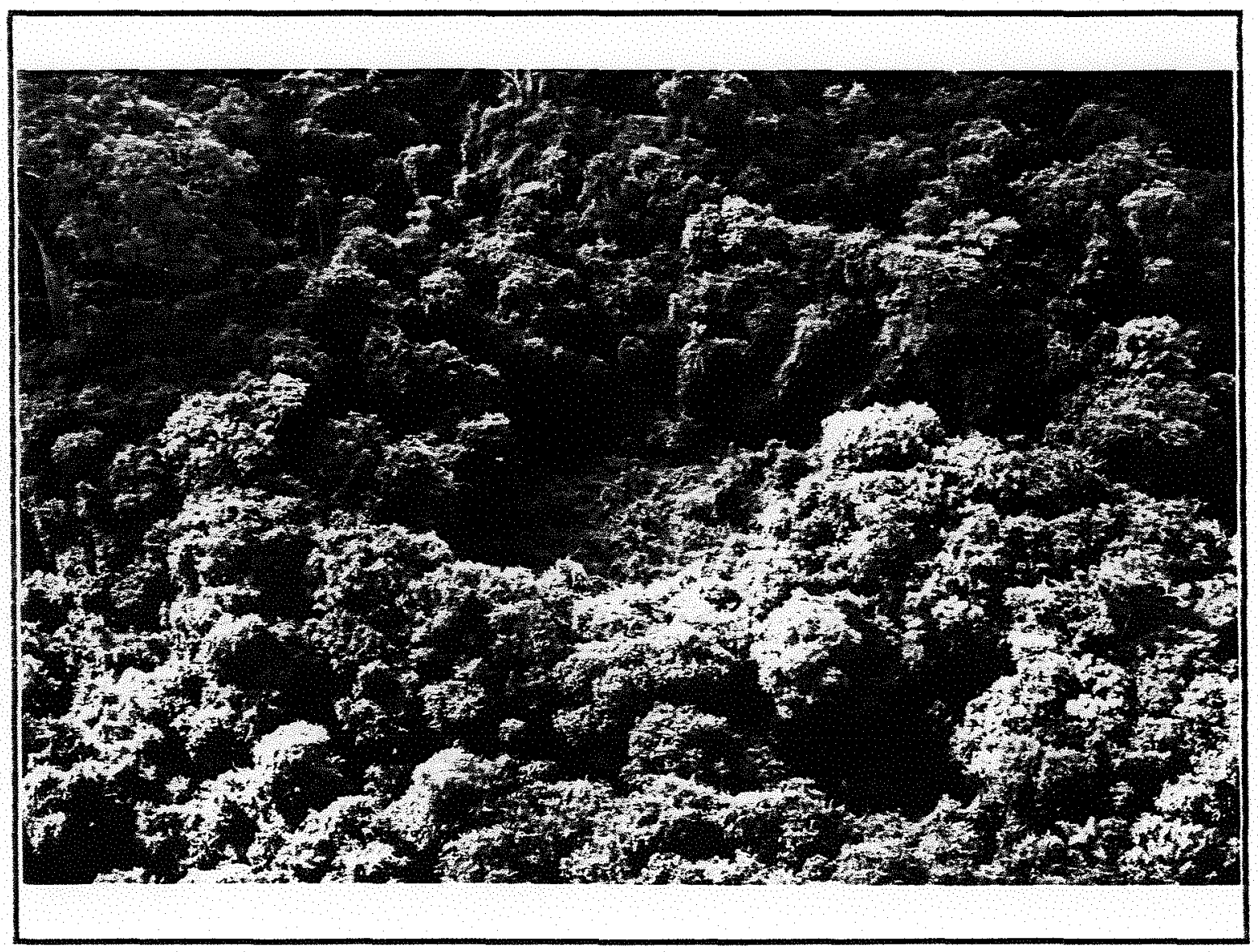


Figura 23- PROCESSOS EROSIVOS OCORRENTES EM ÁREA VIZINHA DA ESTAÇÄO ECOLÓGICA DE IBICATU

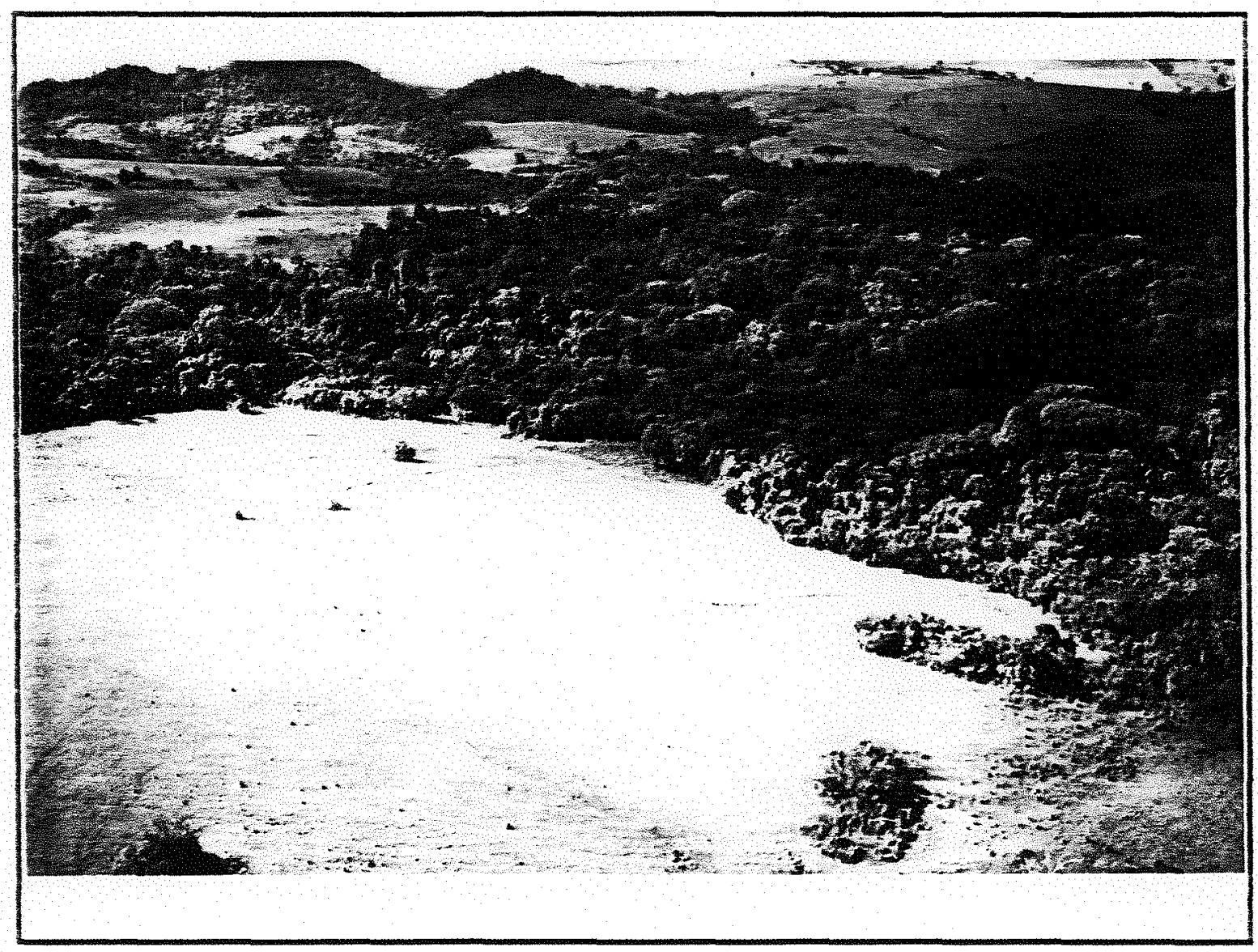


Figura 24 - PROCESSOS EROSIVOS OCORRENTES EM ÁREA VIZINHA DA ESTAÇAOO ECOLÓGICA DE IBICATU (2)

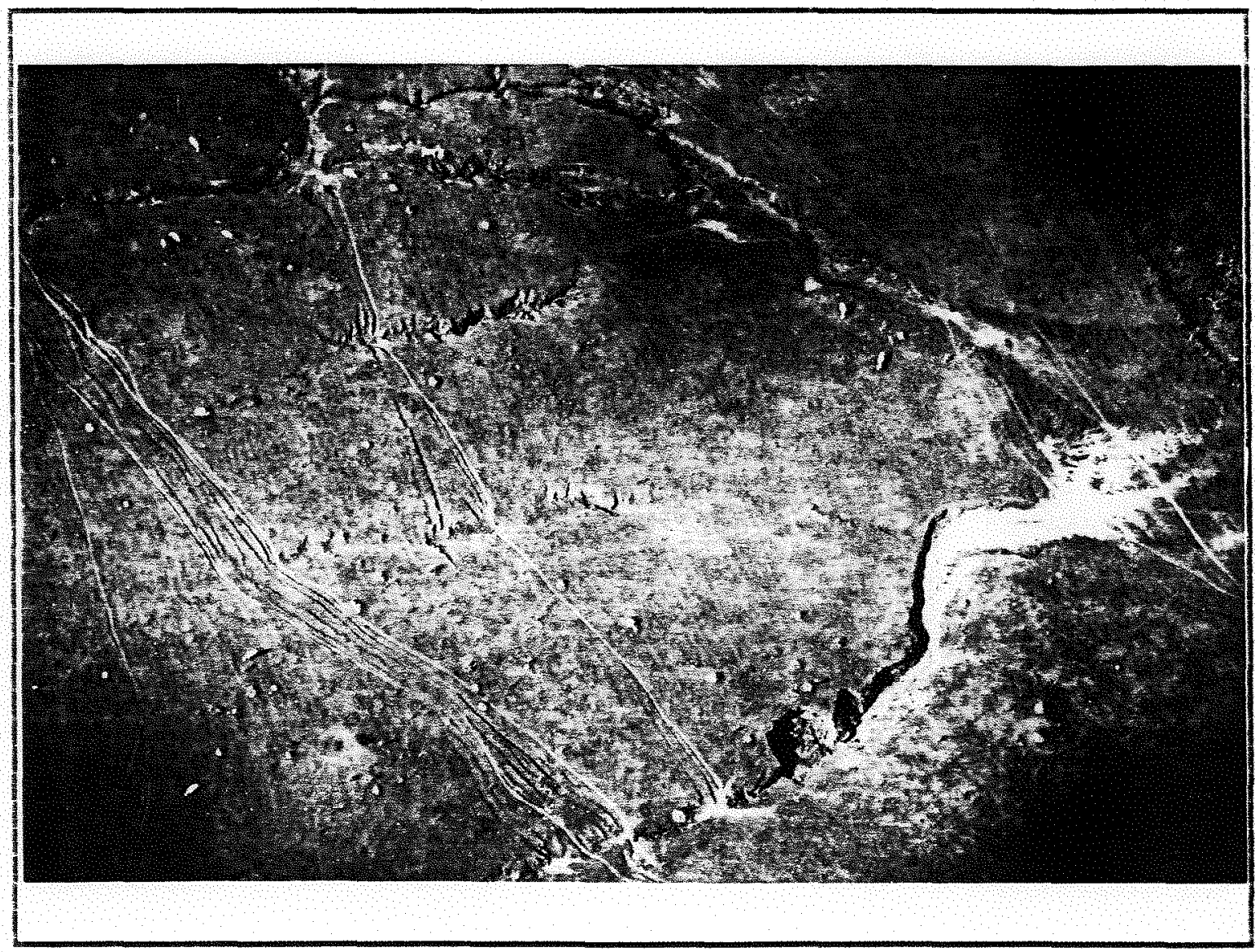


Figura 25 - AREAS DEGRADADAS EXISTENTES NO ENTORNO DA ESTAÇÃO ECOLÓGICA DE IBICATU

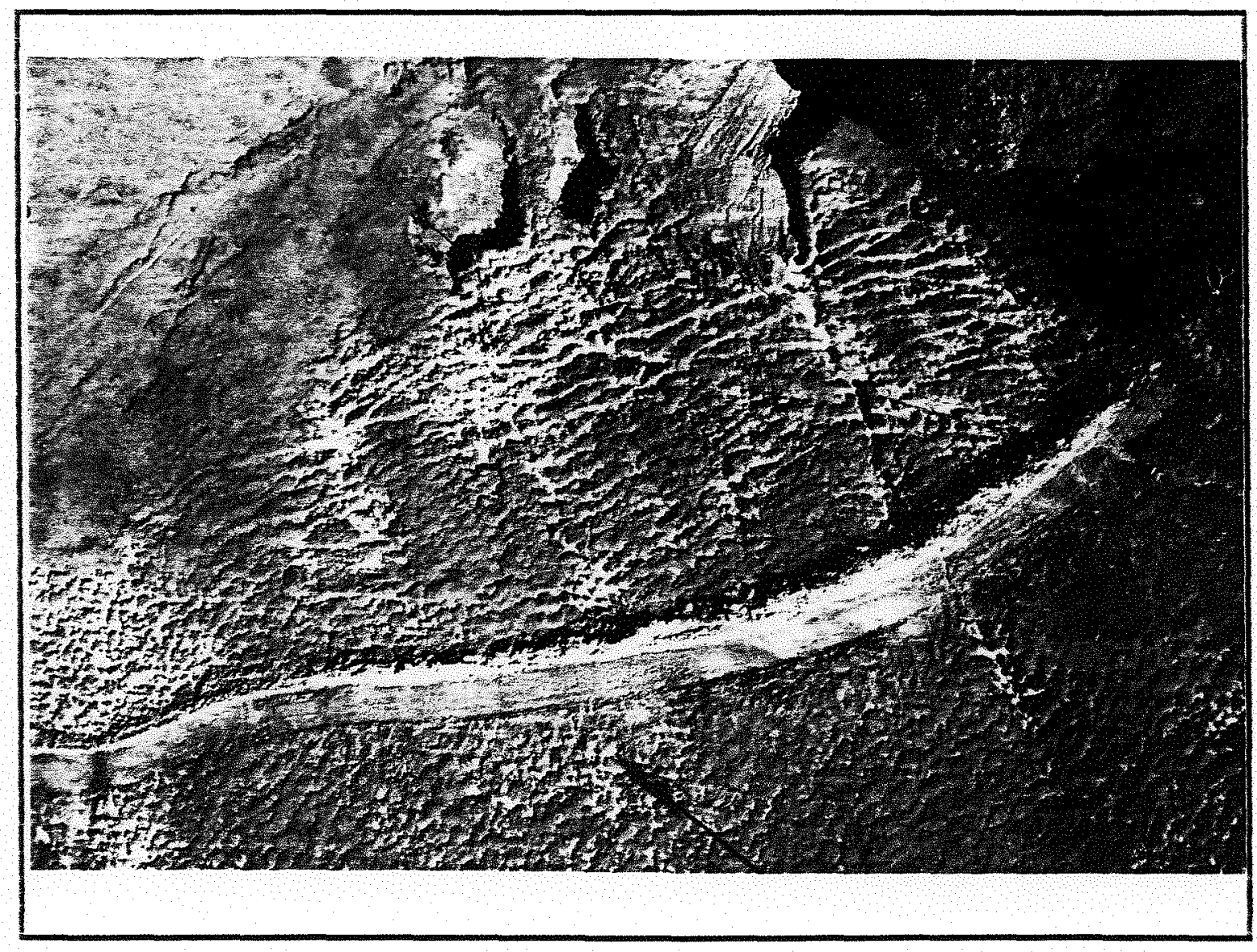


verdadeiros "bancos" de solo, assoreando os córregos existentes dentro da floresta. Nesses locais, devido ao acúmulo de água, as espécies arbóreas acabam morrendo e criando condições para o desenvolvimento de plantas rasteiras e arbustivas, conforme pode ser observado nas fotos abaixo.

d) A falta de manejo adequado está fazendo com que em muitos pontos ocorra o desenvolvimento excessivo da vegetação arbustiva, além da presença de bambus e cipós, prejudicando as espécies arboreas e ocasionando clareiras na floresta, que tendem a aumentar no decorrer do tempo.

e) Observou-se a invasão constante de gado no interior da Estação Ecológica, em funçăo da inexistência ou precariedade das cercas divisorias. Os animais provocam danos físicos na vegetação e formam trilhas indesejaveis no interior da floresta, podendo se tornar muitas vezes pontos de processos erosivos.

\subsection{Contexto sócio-econômico e cultural:}

\subsubsection{Características da população regional:}

A Estação Ecológica de lbicatu está localizada dentro da região de governo de Piracicaba, que se situa na parte centro-leste do Estado de São Paulo e compreende os seguintes municipios: Águas de São Pedro, Capivari, Charqueada, Elias Fausto, Mombuca, Piracicaba, Rafard, Rio das Pedras, Santa Maria da Serra, São Pedro. Os limites da região são: ao Norte, Rio Claro, ao Sul, Sorocaba, ao Leste, Limeira e Campinas e ao Oeste, Botucatu. (SÃO PAULO, SECRETARIA DE ECONOMIA E PLANEJAMENTOO, 1990).

Em 19/05/1992, o Distrito de Saltinho, pertencente a Piracicaba, adquiriu autonomia de Município, com uma area total de 113 quilometros quadrados e uma população calculada em 6.500 habitantes, segundo cálculos extra-oficiais. (Jornal de Piracicaba, 19/05/94), passando a fazer parte da Região Administrativa de Piracicaba. 
Tabela - 13

POPULAÇÃO REGIÃO DE GOVERNO DE PIRACICABA 1992

\begin{tabular}{|l|r|}
\hline MUNICIPIO & TOTAL DE HABITANTES \\
\hline Águas de São Pedro & 1.751 \\
\hline Capivari & 34.937 \\
\hline Charqueada & 10.882 \\
\hline Elias Fausto & 11.916 \\
\hline Mombuca & 2.589 \\
\hline Piracicaba & 239.385 \\
\hline Rafard & 8.835 \\
\hline Rio das Pedras & 19.561 \\
\hline Santa Maria da Serra & 4.428 \\
\hline São Pedro & 20.665 \\
\hline Total & 404.949 \\
\hline
\end{tabular}

Fonte: Fundação Sistema Estadual de Análise de Dados - SEADE - 1993 
De acordo com o SEADE (1993), a região de Piracicaba ocupa uma area de 3.515 quilometros quadrados, e em 1991 possuia uma taxa de urbanização de $90,63 \%$, (percentual da população nos municípios em relação à população total), densidade demográfica de $112,80 \mathrm{hab} / \mathrm{km}^{2}$. A taxa geométrica de Crescimento Anual da População (1980/1991) foi de $2,70 \%$.

A sede desta região de governo e o municipio de Piracicaba, em cujo perimetro se localiza a Estação Ecológica de Ibicatu. Segundo o SEADE (1993) este municipio. com área de 1.452 quilometros quadrados, tinha em 1991 uma taxa de urbanizaçâo de $95,11 \%$ e uma densidade demográfica de $195,34 \mathrm{hab} / \mathrm{km}^{2}$, portanto bem acima dos números apresentados na região. A taxa geométrica de crescimento anual da população $(1980 / 1991)$ fol de $2,58 \%$, ficando abaixo da taxa registrada na regiâo.

Ocorre que, ainda segundo o SEADE (1993) se de um lado, as taxas de natalidade (1) em Piracicaba vém apresentando um decréscimo de 27,82 por mil, em 1980 para 19,96 por mil em 1991 , por outro lado, a taxa de Nati-mortalidade (2) caiu de 16,85 por mil, em 1980 para 7,98 por mil em 1991. Tambem a taxa de Mortalidade Infantil (3) caiu de 42,80 por mil, em 1980 para 24,65 por mil, em 1991. Normalmente, as quedas das taxas de natalidade, de Nati-mortalidade e de mortalidade infantil costumam ser interpretadas como conseqüéncias da melhoria de qualidade do nível de vida da população.

(1) Taxa de natalidade $=$ Nascidos vivos, residentes no municipio, registrados durante $o$ ano considerado, por mil habitantes.

(2) Taxa de Natimortalidade = Nascidos mortos (com 28 semanas ou mais de gestaçăo), residentes no municipio, registrados durante 0 ano considerado, por mil nascidos vivos no mesmo ano.

(3) Taxa de Mortalidade Infantil = Óbitos de menores de um ano, residentes no municipio, ocorridos durante 0 ano considerado, por mil nascidos vivos no mesmo ano. 


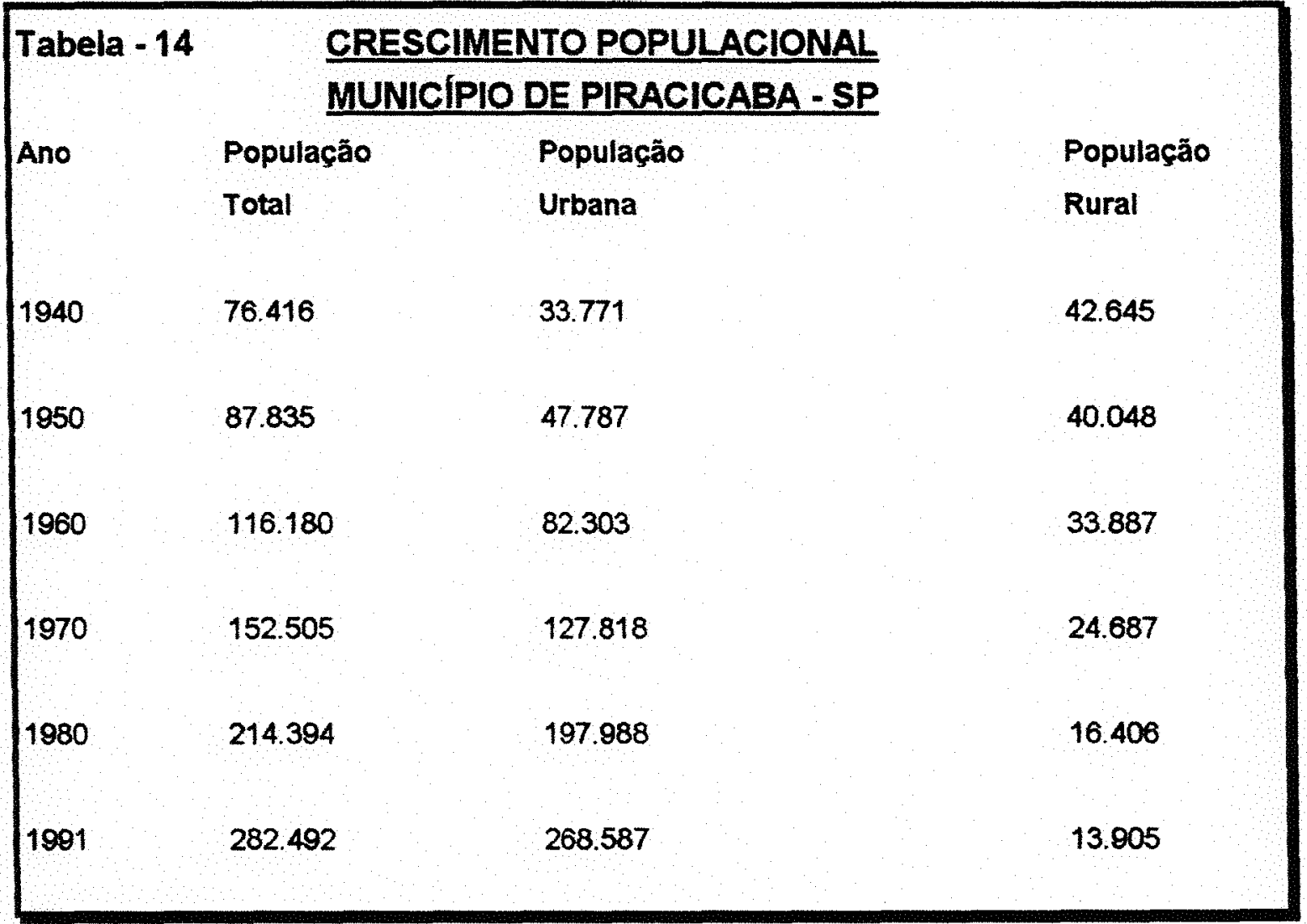

SEADE - 1993

Fontes: PREFEITURA MUNICIPAL DE PIRACICABA - 1992

IBGE - Instituto Brasileiro de Geografia e Estatistica.

SEADE - Fundação Sistema Estaduà! de Análise de Dados, 1993. 
Figura 26 - POPULACÃO URBANA E RURAL - MUUNICÍPIO DE PIRACICABA $1980-1991$

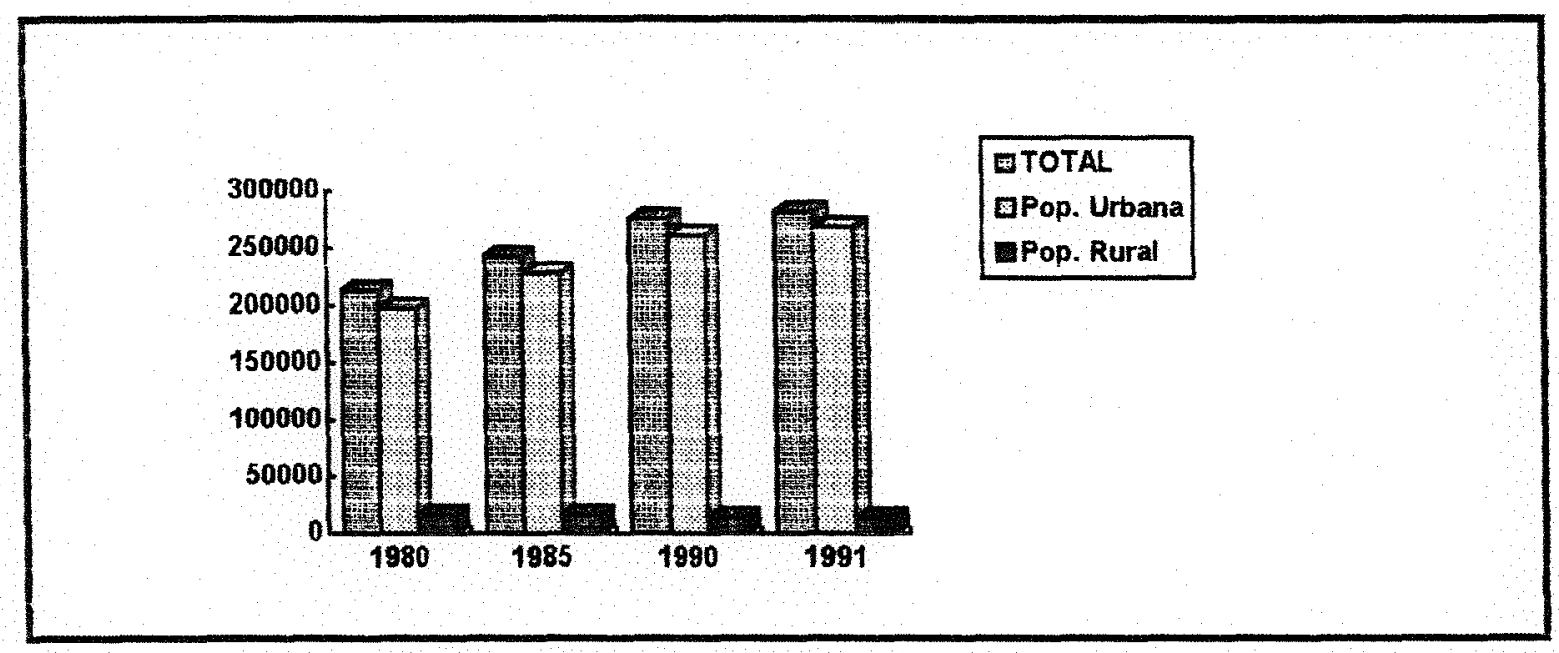

Fonte: Fundação Sistema Estadual de Análise de Dados - SEADE - 1993 


\subsubsection{Evolução urbana no município de Piracicaba:}

Os estudos de evolução urbana mostram que a grande expansăo da cidade verificou a partir dos anos 60 . No final daquela década, iniciou-se a expansão acentuada de toda a periferia, ultrapassando a Leste o ribeirão Piracicamirim, a Noroeste o bairro de Santa Terezinha, e ao Sul, 0 bairro da Paulicéia $O$ fortalecimento do setor industrial, naquela época gerou novos empregos, acelerando o processo do exodo rural Com isso, muitos agricultores mudaram-se para a cidade, com a esperança de uma melhor qualidade de vida (ver Figura 26), acelerando o crescimento urbano. Estima-se que atualmente, apenas $4 \%$ da população piracicabana ainda resida na zona rural (SECRETARIA MUNICIPAL DE PLANEJAMENTO DE PIRACICABA, 1992).

No período de 1974 a 1983 , a população piracicabana cresceu $88,88 \%$, enquanto que a area urbanizada expandiu-se $124,57 \%$, superando as necessidades de ocupação. Apareceram loteamentos periféricos, normalmente afastados do centro urbanizado, provocando a ocorrência de enormes vazios. (PREFEITURA MUNICIPAL DE PIRACICABA, 1988). A taxa de urbanizaçăo continuou elevada nos anos seguintes, atingindo $96,5 \%$, em 1991, segundo 0 Banco de Dados da SECRETARIA MUNICIPAL DE PLANEJAMENTO DE PIRACICABA, outubro, 1992).

Em decorrencia deste intenso processo de urbanização, a cidade passou a ter dificuldades para abrigar os novos habitantes. As favelas, que começaram a surgir na década de 70 apresentaram acentuado crescimento: eram 13 em 1978, 22 em 1982 e em 1992, havia 52 núcleos de favelas, onde moram cerca de 20 mil pessoas. (PREFEITURA MUNICIPAL DE PIRACICABA, 1988, SECRETARIA MUNICIPAL DE PLANEJAMENTO, 1992).

Atualmente, o municipio de Piracicaba tem uma área total de 1.421 quilômetros quadrados, sendo que 177,26 quilómetros quadrados são de 
área urbana, representando $12.48 \%$ e 1.243 .72 quilómetros quadrados sâo de area rural, representando $87,72 \%$.

\subsubsection{Aspectos da Economia Local:}

Como já foi citado anteriormente, desde a sua fundação, Piracicaba firmou-se como um municipio eminentemente agricola até a virada deste século, quando se iniciou o processo de formação e desenvolvimento de seu parque industrial. Atualmente. o quadro da economia local apresenta relativa estagnaçăo do setor industrial, enquanto se observa um razoavel crescimento no setor terciário, representado pelas atividades comerciais e de prestaçóes de serviço.

- Setor primário:

O Município de Piracicaba, até periodos mais recentes sempre "teve como caracteristica principal, no seu aspecto económico, de forma direta ou indireta, uma estreita dependencia do setor agricola para a formação do seu produto". (CENTRO MUNICIPAL DE PLANEJAMENTO, 1985), Neste contexto, destaca-se o cultura da cana-de-açúcar como a de maior expressão económica, não só no municipio, mas em toda a regiáo.

A atividade pecuaria nunca chegou a apresentar grande destaque na economia piracicabana. A produção de alimentos, que diminuiu em decorrência do processo de éxodo rural, recebeu algum impulso a partir da decada de 80 , com a criaça dos centros de comercialização municipais ("varejōes"), que incentivou o plantio de hortifrutigranjeiros. Observa-se tambem no município a pequena produção de cereais, laranja e de fumo.

Uma análise da estrutura fundiária, por sua vez, demonstra que a propriedade agricola no Municipio, tende, em épocas mais recentes, para uma concentração de grandes propriedades, resultante da intensificação da monocultura canavieira. 
De acordo com o Instituto Brasileiro de Geografia e Estatistica - IBGE - citado pela Secretaria de Economia e Planejamento (1990) a estrutura fundiária na regiáo de governo de Piracicaba está concentrada entre 1980-1985. Os 43 estabelecimentos com mais de 1,0 mil ha, concentrando $25,5 \%$ da area agricola ampliam-se para 46 estabelecimentos, que passam a responder por $27,8 \%$ da área agricola total. Enquanto isso, ocorre queda de $14 \%$ no número de estabelecimentos com menos de 10 ha. e o pequeno aumento no número de estabelecimentos com area entre 10 a 100 ha., que passam de 1.816 para 1.824 propriedades.

Segundo SPAROVECK et alii (1993), quando comparamos o uso da terra em 1962 com 1991 no municipio de Piracicaba, o fato que mais chama a atenção e o avanço da cultura canavieira. Esta representava $35 \%$ da area total em 1962 e passou a $50 \%$ em 1991. As areas de pastagem, caracteristicamente extensivas, diminuiram de $43 \%$ em 1962 para $25 \%$ em 1991. Nesta expansão a cana-de-açúcar substituiu em torno de 24.000 hectares de pastagens e pouco mais de 3.000 hectares de areas anteriormente ocupadas principaimente com a produçăo de alimentos.

- Setor secundário:

A industrialização no municipio de Piracicaba surgiu em decorrência do setor agricola, tendo evoluido a partir da produção de açúcar nos antigos engenhos, os quais, ao longo do tempo transformaram-se em modernas usinas. "Com a instalação das usinas abrem-se perspectivas para novos ramos industriais, especialmente os metalúrgicos e mecánicos que, inicialmente implantam suas fábricas apenas para complementar o parque açucareiro, no que se refere a reparaçăo e conserto, e mais tarde concentram-se no fabrico de componentes para produção de açúcar" (PIRACICABA, PLANO DIRETOR DE DESENVOLVIMENTO, 1974).

A alividade industrial em Piracicaba teve grande crescimento na década de 70 , em decorrência da politica de incentivos criada pelo poder municipal e do processo de interiorização do desenvolvimento. Mais tarde, no 
inicio da década de 80, com o advento do Programa Nacional do Álcool (PROALCOOL), a regiáo tornou-se a principal fornecedora de bens de produção para o setor sucro-alcooleiro, aquecendo a economia local.

Segundo a Prefeitura Municipal de Piracicaba, em 1991 Piracicaba contava com 3.050 estabelecimentos industriais. De acordo com 0 SEADE (1993), o número de pessoal ocupado na indústria (volume médio anual empregado) em 1990 era de 28441 pessoas.

- Setor terciario:

Em decorrencia do progresso alcançado nas décadas de 70 Piracicaba se destacou como grande prestadora de serviços, "contando com uma infra-estrutura expressiva em termos de aparelhamento e diversificação, cujo atendimento atinge outras localidades em seu entorno, garantindo-lhe desta forma a posição de pólo subregional" (PIRACICABA, PLANO DIRETOR DE DESENVOLVIMENTO, 1974).

Com a diminuição do ritmo do crescimento industrial, a partir dos anos 80 , observou-se no município um expressivo crescimento das atividades do setor terciário, particularmente nas vinculadas ao comércio varejista $\odot$ atacadista, a prestação de serviços, ao transporte e comunicaçōes e nas atividades sociais (SÃO PAULO, SECRETARIA ESTADUAL DE ECONOMIA F PLANE JAMENTO, 1990).

Um importante passo neste setor fol dado com a instalaçâo do Shopping Center Piracicaba, no Bairro da Vila Rezende, em outubro de 1987 , que, atendendo toda a regiáo, com uma centena de novas lojas, gerou cerca de 2.000 novos empregos e ajudando a descentralizar a atividade comercial, até então restrita à área central.

De acordo com a Prefeitura Municipal de Piracicaba, em 1991, o município contava com 8.250 estabelecimentos comerciais e 49 agencias bancárias. O SEADE (1993) estimou que em 1990 o pessoal ocupado 
no comércio (volume médio anual de empregados) era 15.879 e o pessoal ocupado em serviços era de 32.357 .

\subsubsection{Aspectos culturais:}

\section{a) Equcação:}

De acordo com a Prefeitura Municipal de Piracicaba (1991) a rede escolar de primeiro e segundo grau no municipio contava com 126 estabelecimentos (estaduais e particulares). Além disso, a Prefeitura atua $\mathrm{em}$ três niveis com 56 Centros Educacionais, Creches e Parques Infantis, atendendo a 6.440 crianças em idade pré-escolar. (Tabela 15)

Piracicaba conta com cinco estabelecimentos em nivel superior: a Escola Superior de Agricultura "Luiz de Queiroz" (ESALQ), campus Piracicaba, da Universidade de São Paulo, a Universidade Metodista de Piracicaba (UNIMEP), a Faculdade de Odontologia de Piracicaba, da UNICAMP (Universidade de Campinas), a Escola de Engenharia de Piracicaba (EEP) da Fundação Municipal de Ensino, a Faculdade de Serviço Social e finalmente o CENA - Centro de Energia Nuclear Aplicada à Agricultura, que só atua em nive! de pós-graduaçâo. No primeiro semestre de 1991 estavam matriculados 10.258 alunos (de graduação) nestas instituições, distribuidos conforme mostra a Tabela 16. 
Tabela 15 - REDE DE ENSINO PRÉ-ESCOLA - PRIMEIRO E SEGUNDO GRAU - MUNICIPIO DE PIRACICABA - 1991

\begin{tabular}{|l|r|r|r|r|}
\hline $\begin{array}{l}\text { Matrícula } \\
\text { Inicial }\end{array}$ & Total & $\begin{array}{l}\text { Rede } \\
\text { Estadual }\end{array}$ & $\begin{array}{l}\text { Rede } \\
\text { Municipal }\end{array}$ & \multicolumn{2}{l|}{$\begin{array}{l}\text { Rede } \\
\text { Particular }\end{array}$} \\
\hline Pré-escola & 7.636 & 695 & 5.563 & 1.378 \\
\hline Primeiro grau & 53.629 & 46.673 & & 6.956 \\
\hline Segurido & 9.512 & 7.036 & & 2.474 \\
grau & & & & \\
\hline Totais & 70.777 & 54.406 & 5.563 & 10.808 \\
\hline
\end{tabular}

Fonte: Fundação Estadual de Sistema de Anáise de Dados- SEADE - 1993 
Tabela 16 -

REDE DE ENSINO SUPERIOR

MUNICIPIO DE PIRACICABA - MARÇO/92

\begin{tabular}{|l|r|r|r|r|}
\hline Instituição & Professores & Graduação & $\begin{array}{l}N^{0} \text { Alunos } \\
\text { Especializ. }\end{array}$ & $\begin{array}{l}\text { Pós- } \\
\text { graduação }\end{array}$ \\
\hline UNIMEP & 475 & 7.651 & 279 & 179 \\
\hline ESALQ & 247 & 1.136 & & 888 \\
\hline FOP & 91 & 321 & & 108 \\
\hline CENA & 44 & & & 68 \\
\hline EEP & 68 & 1.000 & & \\
\hline Serviço Soc. & 22 & 150 & 45 & 1.243 \\
\hline TOTAL & 947 & 10.258 & 324 & \\
\hline
\end{tabular}

Fontes:

Prefeitura Municipal de Piracicaba; Universidade Metodista de Piracicaba (UNIMEP); Escola Superior de Agricultura "Luiz de Queiroz" (ESALQ), Faculdade de Odontologia de Piracicaba (FOP); Centro de Energia Nuclear Aplicada a Agricultura (CENA); Escola de Engenharia de Piracicaba (EEP); Faculdade de Serviço Social de Piracicaba (1992) 


\section{b) Cultura Turismo e Lazer:}

Justificando a sua rica tradição, Piracicaba, que já foi chamada no inicio deste século de "Atenas Paulista", tem hoje uma intensa vida cultural Neste campo destaca-se o Teatro Municipal Dr. Losso Neto, inaugurado em 1978 , com capacidado para 720 pesscas na sala principal, e um teatro de arena (sala 2) com 148 lugares, que tem uma variada programação durante todo o ano.

Alem disso, há inumeras instituições atuando em áreas especificas que realizam múltiplas atividades voltadas para a cultura e o lazer. As mais importantes são: a Casa das Artes Miguel Arcanjo Benicio Dutra, o Museu Histórico e Pedagógico Prudente de Moraes (1953), a Academia Piracicabana de Letras (1972), o Instituto Historico e Geografico de Piracicaba (1967) e o Centro Cultural e Desportivo Comendador Valentim dos Santos Diniz (1979), do SESC (Serviço Social do Comércio), e o espaço cultural Casa do Povoador (1987).

Graças as suas caracteristicas fisicas representada principaimente pelo belo salto e do rio, Piracicaba atrai muitos turistas durante todo 0 ano. Os principais eventos turisticos foram incluicios no calenciálio oficial, que se inicia en fevereiro, com o carnaval, prossegue em março, com a festa do milho verde no distrito de Tanquinho, seguida da festa das naçóos, no mês de maio. Em junho, ocorre a tradicional festa de São João, no Distrito de Tupi e em julho, a festa do Divino, que costuma arrastar verdadeiras multidóes para a Rua do Porto, às margens do rio, onde nasceu a cidade.

A infra-estrutura de Piracicaba voltada para a cultura e o lazer compreende ainda cinco cinemas, seis centros de lazer, dois museus, sete parques públicos, dezessete clubes esportivos, dois jornais diarios, quatro emissoras de rádio, uma repetidora de televisão e uma biblioteca pública. 


\section{Discussão e prognósticos:}

\subsection{Considerações gerais}

O papel da Estação Ecológica de lbicatu pode ser analísado em dois niveis distintos. O primeiro diz respeito à sua função como simples elemento de proteção imediata do hábitat, das comunidades bióticas que ele abriga e da sua grande beleza cénica, especialmente representada pelos imponentes jequitibás (Cariniana spp.) ali existentes. Outro nivel, muito mais abrangente, enfoca 0 complexo problema da conservação genética das populações, procurando, através do conhecimento cientifico, assegurar a manutenção dos processos evolutivos no ecossistema local, garantindo dessa forma a perpetuação das especies.

Nesse contexto, a situação do fragmento florestal estudado, com suas pequenas dimensões e sofrendo um considerável isolamento geográfico, sugere a ocorrência de erosão dos seus recursos genéticos. Tal hipótese fica ainda mais fortalecida quando se considera a grande interdependencia existente entre as especies que ali convivem, bastando lembrar que a avaliação da síndrome de dispersão das espécies vegetais arboreas, verificada por COSTA (1992), demonstrou que $62 \%$ das especies estudadas eram zoocóricas. Isto confirma a importancia da fauna no mecanismo de dispersão da vegetação local.

Dessa forma, o tamanho da Estação de Ibicatu, o grau de isolamento em que se encontra, dificultando a translocação de material genético e os aspectos de ocupação inadequada do solo no seu entorno, somados a sua forma espacial insatisfatória, em termos da sua consenvação, justificam a 
necessidade de se efetuar estudos aprofundados para determinar as condições ideais para a estabilidade desta Unidade de Conservação.

Assim, devem ser conhecidos os aspectos reprodutivos das espécies que ali se desenvolvem, especialmente na área da genecologia, avaliando 0 fluxo gênico entre as populações vegetais estabelecidos pelos mecanismos de dispersão de pólen e sementes. Como eles são diretamente relacionados com os animais e a sua distribuição geográfica, tornase tambem necessario avaliar a fauna sob esta ótica, para se formular hipoteses sobre o tamanho mínimo destas populações e orientar os programas de conservação in situ.

Com base nestas considerações, pode-se pressupor a extrema importancia de se efetuar a ligação física da Estação Ecológica de Ibicatu com outras pequenas matas remanescentes, existentes no seu entorno, de forma a criar verdadeiros corredores vegetados, que possibilitem a circulação dos animais entre eles, funcionando como verdadeiras pontes para troca de material genético, garantindo assim que todas as espécies que ali habitam, além de ter a sua sobrevivência assegurada, possam continuar naturalmente o seu processo evolutivo.

Outro ponto importante a ser avaliado e a necessidade da expansão física da area desta Estação, com a aquisição de glebas vizinhas, atualmente em posse de proprietários particulares. Elas serviriam para criar uma zona-tampão (Figuras 27 e 28), cuja função e aumentar o grau de proteção da floresta. Esta expansão contribuiria tambem para melhorar a sua forma, aumentando a sua area nuclear e diminuindo o "efeito de borda" nos limites da Unidade de Conservação. Esta area a ser incorporada serviria tambem abrigar as edificaçóes necessarias ao perfeito cumprimento das suas finalidades estabelecidas.

Independentemente destas eventuais aquisições de glebas anexas a área, é conveniente que a Estação Ecológica seja administrada e manejada em função da conservação da microbacia hidrográfica local, garantindo o controle ambiental das nascentes dos cursos d'agua. Para tanto, os órgãos competentes devem estabelecer as diretrizes adequadas para o desenvolvimento de atividades agropecuarias no seu entorno, bem como fiscalizar eficientemente a observação da sistematica proposta. 
Figura 27 - ESTAÇÃO ECOLÓGICA DE IBICATU: PROPOSTA DE AREA A SER ADQUIRIDA - Escala 1:10.000

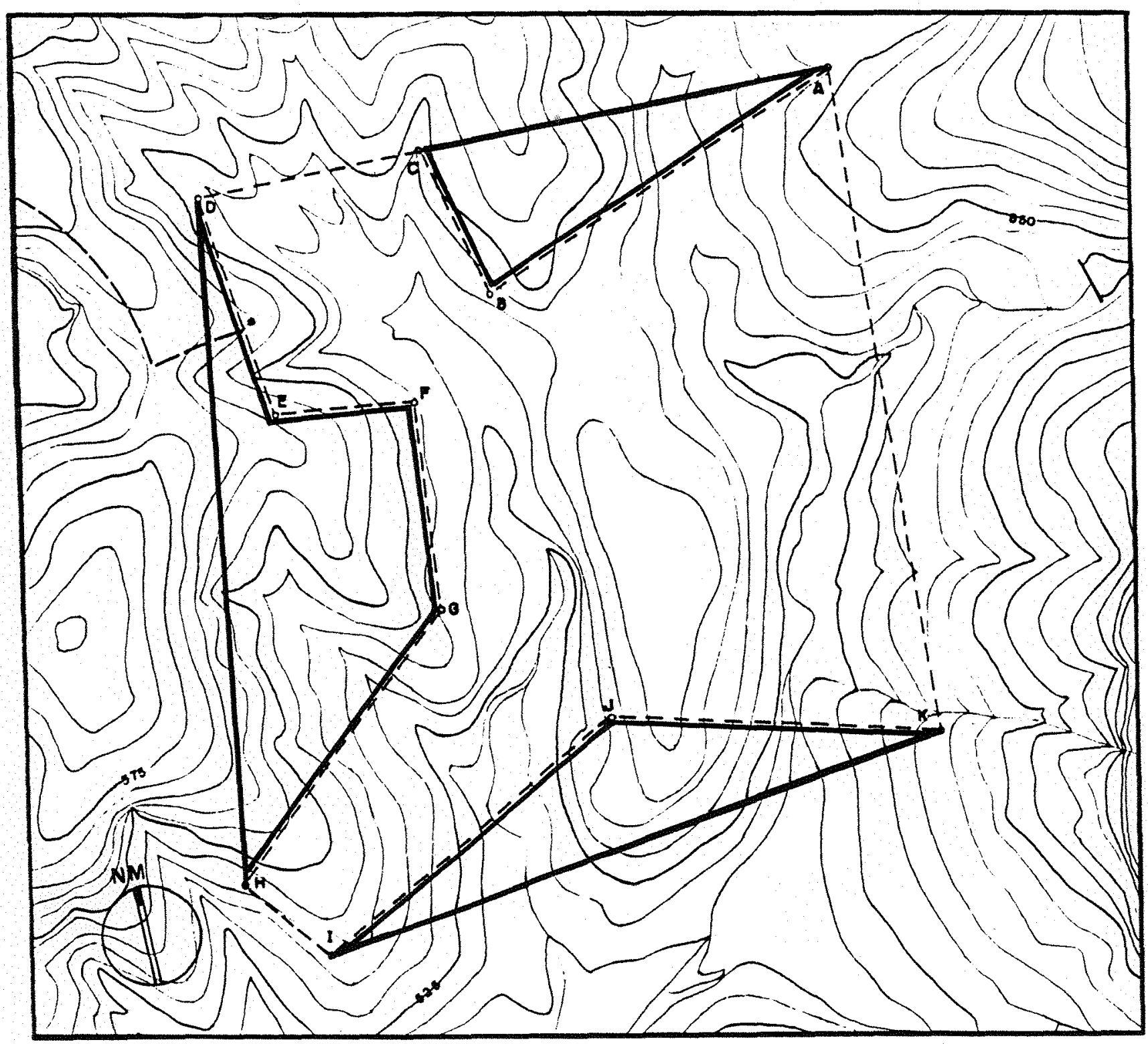

LEGENDA

G ÁREA ATUAL

AREA A SER ADQUIRIDA 
Figura 28 - ESTAÇÃO ECOLÓGICA DE IBICATU: SUGESTÃO PARA CRIAÇÃO DE ZONA "TAMPÃO" COINCIDENTE COM OS

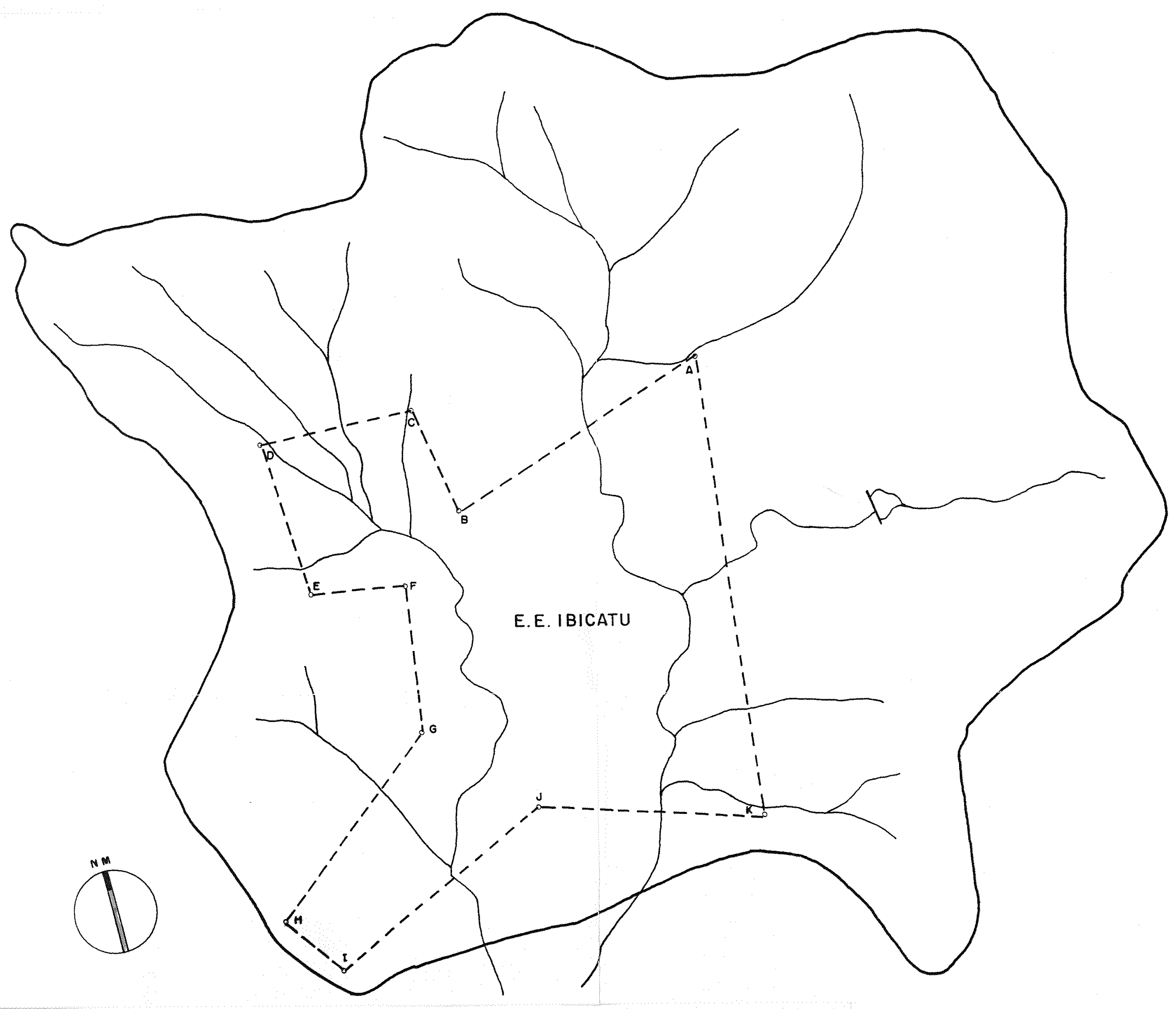




\subsection{Proposta para organização espacial:}

A base para qualquer intervenção na Estação Ecológica de Ibicatu e a definição do uso do solo local, através de um zoneamento adequado da área, que leve em conta a necessidade de sua conservação e os programas de uso que incluem exclusivamente atividades de pesquisa cientifica e de Educação Ambiental.

Neste sentido, propóe-se a seguinte setorização da area, (Figura 29) em runção destas atividades permitidas, levando em conta o grau de preservação dos ecossistemas locais, a susceptibilidade do solo a processos erosivos, a funcionalidade das operaçðes a serem ali desenvolvidas e procurando sempre manter un conário desejável do ponto de vista paisagístico:

a) Zona primitiva: (ZP) Este setor é aquele onde a natureza deve permanecer intacta, como depositario das especies da fauna e da flora, não se permitindo qualquer alteração humana, sendo dedicada a proteçáo integral do ecossistema e ao monitoramento ambiental. No caso de lbicatu, compreende quase a totalidade da área. A pesquisa cientifica ali realizada não poderá causar nenhum tipo de modificação no local, devendo ser devidamente autorizada pelo orgăo gestor competente.

b) Zona de uso extensivo: (ZE) E' o setor onde a utilização humana se dá sob controle e em baixa intensidade. Nesta zona, destinada exclusivamente aos programas de Educaçáo Ambiental, sera possivel construir pequenas obras para a instalação de triihas, tais como pequenas escadas e pontes de madeira, bancos rústicos em locais adequados, entre outros. No caso da Estação Ecologica de lbicatu, a unica trilha prevista $e$ que dara acesso ao Grande Jequitiba c seu entorno, ponto de atração maxima do local. A utilização desta zona deve ser precedida de um estudo especifico da sua "capacidade de carga", definida como "a quantidade de uso que pode ser mantida em um tempo especifico sem causar prejuizo ao ambiente ou as experiencias dos visitantes". (IBDF/FBCN, citado por SILVA, 1992a), de forma que nào apresente nenhuma 
ameaça aos recursos da Estação Ecológica.

c) Zona de uso intensivo: (ZI) Situada em locais alterados pelo homem. Deverá ser dotada de infra-estrutura e edificaçóes necessárias para receber o público, quer pesquisadores, quer alunos do programa de Educação Ambiental. Neste setor, poderá ser instalado o prédio do Centro de Visitantes, construido de acordo com um partido arquitetônico que o integre ao ambiente local, e assegure um tratamento paisagístico com o emprego de espécies vegetais nativas strictu sensu, harmonizando o conjunto com o cenário do entorno.

d) Zona de recuperação: (ZR) Caracterizada como um setor provisório e representada pelos locais alterados pelo homem que deverâo ser revegetados, mediante o desenvolvimento de projetos especificos. Estas áreas poderão servir como base para a experimentação e pesquisa de modelos de recomposição floristica de matas estacionais semideciduais. As terras a serem adquridas dos vizinhos que se apresentarem sem cobertura arbórea natural (pastagens e plantações) também deverão ser enquadradas nesta categoria de utilização.

e) Zona de uso especial:(ZS) Representada pelas áreas destinadas aos serviços de manutenção da Estação, incluindo o local reservado as residências dos funcionários. Tais áreas são selecionadas de forma a não conflitar com a paisagem natural, localizando-se na sua periferia, devendo permanecer o mais ocultas possivel. Sua instalação poderá ser efetuada em terreno próximo à edificação existente, a ser adquirido futuramente. 
Figura 29 - ESTAÇÃO ECOLOGGICA DE IBICATU: PROPOSTA DE ZONEAMENTO. Escala: 1:10.000

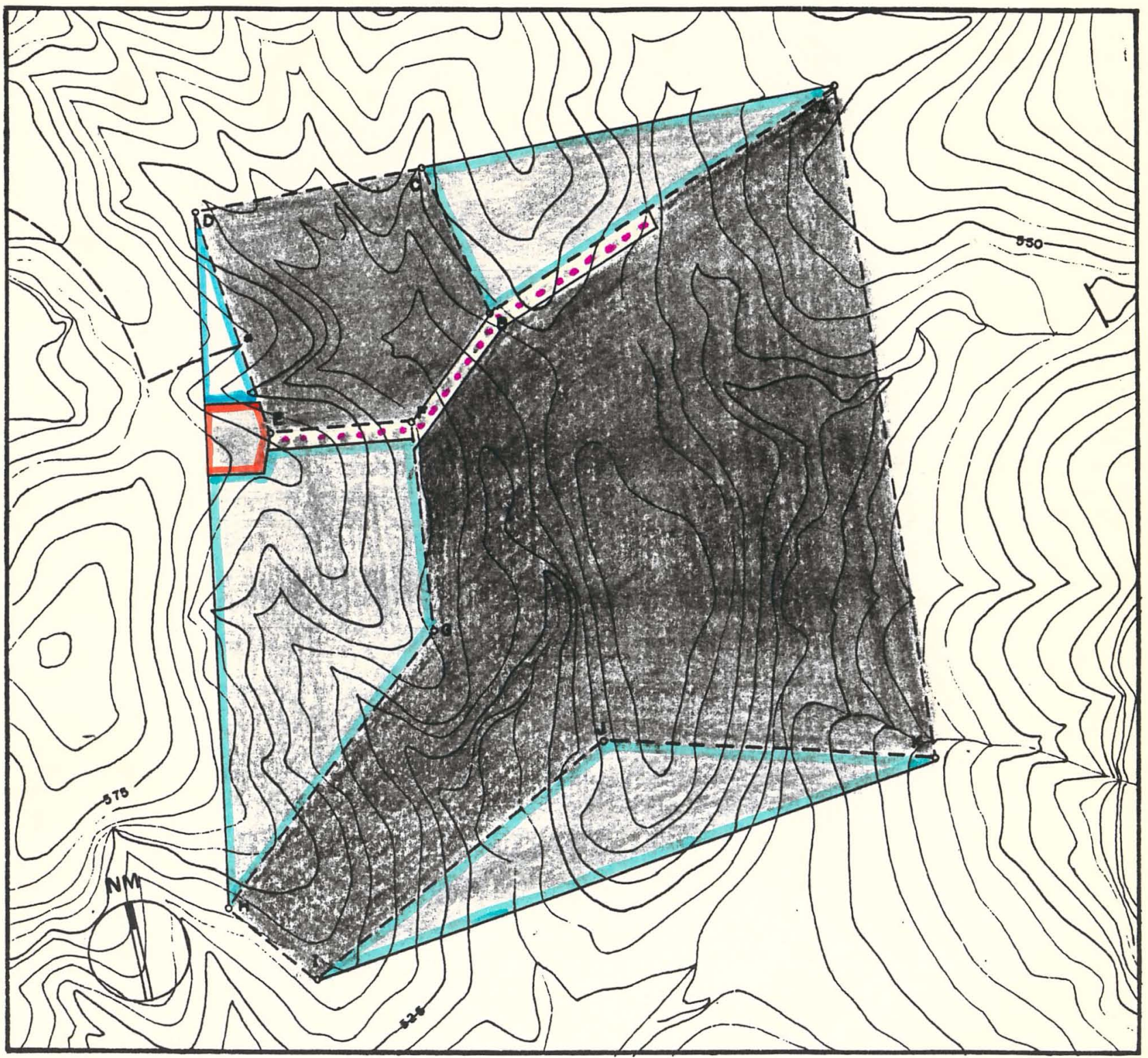

\section{LEGENDA:}

Zona Primitiva

$\square$ Zona de Uso Extensivo

Zona de Uso Intensivo
Zona de Recuperação

Zona de Uso Especial 周圆国同 Trilha 


\subsection{Consideraçöes sobre os programas de manejo:}

Sugere-se que o Plano de Manejo a ser elaborado para a Estação Ecológica de Ibicatu envolva o desenvolvimento de quatro programas especificos, visando a proteção efetiva daquele ambiente natural, e possibilitando a sua utilização adequada, de acordo com as normas legais que a regulamentam, a saber:

- Programa de Desenvolvimento Físico

- Programa de Administração e Manutenção

- Programa de Educação Ambiental

- Programa de Pesquisa

- Programa de Mobilização Comunitaria

\subsection{Programa de desenvolvimento fisico}

- Programa de Desenvolvimento Físico norteará a instalação de toda a infra-estrutura, das edificações e dos equipamentos necessários a serem executados na Estação Ecológica de Ibicatu, com a finalidade de dar suporte aos programas de uso ali propostos, garantindo, simultáneamente, a perfeita conservaçăo daquela Unidade. Desta forma, poderăo ser desenvolvidos os seguintes sub-programas:

\subsubsection{Sub-Programa de implantação de infra-estrutura}

Compreende a instalação da rede de energia elétrica para servir a Unidade, cujo projeto já foi contratado pelo Instituto Florestal, junto a empresa particular e se encontra pronto para ser executado. 
Deverá ser desenvolvido um estudo especifico para definição do sistema de abastecimento de água da Estação Ecológica, incluindo o dimensionamento, em funçăo do consumo previsto e o sistema construtivo a ser empregado para a captação, adução, tratamento e reservaçăo. $E^{\prime}$ importante que o modelo proposto năo cause nenhuma alteraçāo no ambiente local .

Outro ponto importante é a implantaçăo de uma rede de telecomunicação interna e externa, para facilitar os serviços de administraçăo e fiscalizaçảo da área. Algumas alternativas que poderiam ser empregadas sáo o telefone celular, recentemente implantado no municipio, ou aparelhos de rádiocomunicaçăo.

E' fundamental se estabelecer no local um sistema de tratamento e descarga das águas servidas, levando-se em conta as condições de solo, relevo, posiçăo do lençol freático, número de usuarios, entre outros fatores, para determinaçăo de suas características e dimensionamento.

0 destino final de lixo e dejetos precisa também ser estudado, de forma que a soluçăo adotada năo cause nenhum impacto ambiental na Unidade de Conservaçáo. As lixeiras a serem instaladas em pontos estratégicos do local, deveráo ter um aspecto natural.

Dentro do sub-programa de infra-estrutura deverá estar incluida a melhoria efetiva das estradas de acesso a area, a partir da Rodovia SP-147. Assim, a estrada vicinal (PI -173) devera ser cuidadosamente mantida e a estrada de servidão, dentro da Fazenda de propriedade da familia Moraes Barros, devera ser alargada, colocando-se sobre o seu leito material adequado para possibilitar a passagem de velculos em qualquer época do ano. $E^{\prime}$ importante também a construçăo de galerias de águas pluviais, perfeitamente dimensionadas e o revestimento vegetal das margens daquelas vias, impedindo assim a ocorrencia de processos erosivos.

\subsubsection{Sub-Programa de instalação de obras}

- Fechos: 
Em todo o perímetro da Estação Ecológica deverâo ser instaladas cercas de proteçăo, com o emprego de mourões de madeira ou concreto e fios de arame. Uma de suas laterais deverá ser mantida sempre limpa, para possibilitar a perfeita circulação no entorno da área, facilitando as operaçōes de manutenção e fiscalizaçāo Nos pontos em que houver depressões no terreno, em função do relevo estabelecido pelas calhas de drenagem natural, que incluem pequenos cursos d'agua, deverão ser construidas pontes de madeira, preferencialmente empregando-se toras de eucalipto tratado. Estas estruturas devem ser calculadas para suportar o eventual tráfego de veiculos de fiscalização ou de unidades de combate a incêndios.

- Portão de acesso -

Deverá ser construido na entrada da Estação Ecológica um portão para servir como elemento de segurança e controle de acesso an local. Sua arquitetura deverá procurar ressaltar a importancia da Unidade de Conservaçăo, de forma que os visitantes sintam que, a partir daquele ponto, estão adentrando em um santuario da natureza, diferenciado dos locais onde se verifica a ação antropogenica.

- Residências de funcionários.

Devera ser aproveitada a edificação existente, construindose outra nas suas proximidades, com dimensóes e sistema construtivo similares, mantendo-se desta forma um único padrão no local. Estas residências estão localizadas na Zona de Uso Especial e deverão receber um tratamento paisagístico de forma a mantê-las ocultas na paisagem local, com o uso de sebes, que é uma maneira eficiente de se conseguir este efeito.

- Centro de visitantes.

Deverá ser construída na Zona de Uso Intensivo, uma edificaçăo com o objetivo de recepcionar os visitantes e os pesquisadores 
cientificos que ali desenvolvam trabalhos de campo. $O$ prédio em questão deve ser compacto, construido em estilo harmonico com o local. $O$ programa basico compreende: saláo de múltiplo uso (reuniões, exibição de filmes, audiovisuais, exposições), alojamento para cientistas, sala para administração, que poderá conter uma pequena biblioteca sobre informações pertinentes, sanitários e copa.

O prédio deverá contar com estacionamento compativel com o uso previsto (onibus para transporte de escolares e veículos), devidamente arborizado, projetado de forma que a circulação seja funcional e segura.

- Trilha interpretativa -

Recomenda-se a construção de uma única trilha na floresta, situada na Zona de Uso Extensivo, iniciando-se nas imediações do Centro de Visitantes, e terminando no entorno da árvore mais alta ali existente, conhecida como 0 "Grande Jequitibá", ponto de interesse maior dos visitantes. A trilha, com cerca de $1.20 \mathrm{~m}$. a $1.5 \mathrm{~m}$. de largura, deverá ter aproximadamente 650 metros de extensao, passando ao lado dos limites da Zona de Recuperaçao proxima ao Centro de Visitantes, quando poderăo ser observados pelos usuarios os trabalhos de recuperação ambiental e recomposição fioristica.

O seu traçado deverá ser linear, aproveitando-se ao máximo a picada já existente para evitar maiores alteraçōes no ambiente local. Por este motivo a trilha não poderá ser circular, possibilitando o retorno ao ponto de partida, sem passar pelo mesmo local, como sería a situação ideal.

Para que a trilha possa ser convidativa e facilmente percorrida sem grande esforço, exigindo do usuário habilidades especiais, deverăo ser executadas pequenas obras. Assim, deverão ser construldas passagens sobre os cursos d'agua, através de pequenas pontes de madeira, ou pinguelas, de aspecto natural, (ou mesmo com a colocaçăo de pedras estrategicamente posicionadas), escadas rústicas $e$ alguns bancos para descanso. Devera ser efetuada a drenagem nos locais que apresentar acúmulo de aqua e observar-se o pertelto controle da erosao no seus arredores. 
A trilha deve conter ainda placas de comunicação visual discretas e perfeitamente integradas ao ambiente natural com as informações necessárias, tais como sua extensão, posição no visitante com relação à Unidade de Conservação, direção a seguir e demais dados sobre o local.

\subsection{Programa de administração e manutenção}

Este programa objetiva assegurar o controle nerfeito do património biológico e fisico da Estação Ecológica de Ibicatu bem como o adequado desenvolvimento das atividades all propostas. Para tanto, prevë-se a contratação de pessoal, que convenientemente treinado, poderá exercer simultâneamente, as seguintes atividades básicas:

- manutenção: Compreende a realização de serviços gerais, tais como, limpeza sistemática dos aceiros e da trilha do Jequitibá; limpeza e conservação das instalações e equipamentos, para garantir seu perfeito funcionamento: coleta e destinaçâo final do lixo. Inclui-se tambem os trabaihos de jardinagem no entorno das edificaçōes, garantindo sempre um bom aspecto visual do conjunto.

- fiscalizaçâo. Envolve os trabalhos de vigilancia de toda a area, de forma a controlar as atividades que possam representar qualquer tipo de ameaça à Unidade de Conservação. Os vigias deverão dispor de um sistema de comunicação eficiente, para facilitar o patrulhamento da area $F^{\prime}$ importante que estes funcionarios recebam um treinamento especial para eventuais operaçoes de combate a incendios, năo so na floresta, mas tambem nas suas imediaçōes. A prevençáo contra 0 fogo deverá ser reforçada nos periodos mais secos do ano, coincidentes com as queimadas efetuadas na regiâo para facilitar a colheita da cana. Neste aspecto, sugere-se inclusive a formação de uma brigada contra incêndios, com a colaboraçăo da comunidade local, que poderá ser acionada em caso de emergência para trabalhar ao lado dos funcionários da Estação. 
- interpretacão da natureza: Estes trabalhos serão desenvolvidos por guias/monitores, que fornecerào aos visitantes, especialmente aos estudantes, as informações relativas à Estação Ecológica, mostrando-lhes as principais características e destacando sua importancia no contexto de conservaçẫo da natureza.

A administração da Estação Ecológica deverá estabelecer um caderno de encargos, especificando detalhadamente os procedimentos a serem observados na execução dos serviços e os cronogramas que determinam a sua periodicidade. Cabera tambem a ela criar um requlamento interno a ser observado peios visitantes e funcionarios, normatizando as atividades naquela Unidade de Conservaçáo. Neste contexio, não deverá ser, por exemplo, permitida a presença de animais domésticos no local, nem qualquer aproveitamento, pelos funcionários, dos recursos ali disponivcis. Alem disso, qualquer plantio efetuado na area precisa ser previamente aprovado pela administração.

\subsection{Programa de Educaçāo Ámbientai:}

O programa de Educação Ambiental terá como público-alvo o os estudantes que cursam o primeiro e segundo grau das escolas da cidade de Piracicaba e regiáo e será desenvolvido em areas especificas da Unidade de Consenvação. Assim, a recepção aos usuários deverá ocorrer no Centro de Visitantes onde, através de palestras, audiovisuais, exibição de filmes ou painéis explicativos serâo transmitidas as primeiras informaçōes sobre o local. A seguir, podera ser efetuada uma caminhada pela trilha interpretativa, observando-se os diversos pontos de interesse existentes durante o percurso, ate se atingir o Grande jequitiba. Ali, deverá ser ressaltada mais uma vez a importancia deste fragmento florestal único, estimulando os visitantes a apreciar e a desfrutar a paisagem local o mostrando-thes a necessidade de se proteger conveniente 0 património natural.

As atividades de interpretação ambiental poderão desenvolver os seguintes aspectos especificos, entre inumeros outros: 
- observaça das caracteristicas botanicas e fisiologicas da vegetaçăo local;

- aspectos da geologia, dos solos e suas relaçóes com as plantas na floresta,

- observaçôes sobre a fauna existente, mostrando sua interrelação com 0 ambiente e discutindo os problemas decorrentes da alteração e destruição dos seus habitats;

- importancia das matas ciliares para conservaçăo dos recursos hidricos;

- observação sobre o microclima existente no interior da floresta;

\subsection{Programa de Pesquisa:}

Este nrograma objetiva desenvolver estudos cientificos especificos de forma a aumentar os conhecimentos sobre o ecossistema da Estacăo Ecologica de ibicatu. Tais informaçoes poderáo ser utilizadas como subsidios para o desenvolvimento dos outros programas propostos para o local e auxiliar no monitoramento ambiental daquela Unidade de Conservação.

Assim, pesquisadores e técnicos terâo oportunidade de instalar experimentos na area, utilizando como apoio fisico as instalaçōes do Centro de Visitantes. Tais trabalhos só poderão ser realizados com a aprovação previa da administração do Instituto Florestal, e em consonância com a legisiaçăo vigente.

Especial atenção deve ser dada à pesquisas sobre a recomposiçũo floristica da vegetação nativa (floresta estacional semidecidual) $e$ aos estudos relacionados com a determinação do tamanho mínimo viávol do fragmentos florestais naquelas condições de isolamento geografico, bem como sobre as possiveis medidas a serem adotadas para garantir a sua snbrevivencia 
Sugere-se ainda a elaboração de convênios com instituiçôes de ensino e pesquisa, de forma a manter o constante intercambio de iniomaços cientificas que possam, de alguma forma, contribuir nào só para a efetiva conservaçáo daquela área, como tambén cuoperar para o desenvolvmento global das ciencias ambientais.

\subsection{Programa de mobilização comunitária}

A administração da Estaçăo Ecológica de lbicatu deverá incentivar e apoiar acốes da comunidade no sentido obter recursos materiais, financeiros, técnicos e operacionais que contribuam para a aperfeiçoar a manutenção daquela Unidade de Conservação e auxiliar no desenvolvimento dos programas de manejo all propostos, a exemplo do que é feito nos paises desenvolvidos.

Neste sentido, prop̣ne-se a criação de uma "Sociedade de Amigos de Ibicatu", com sede em Piracicaba, regida por estatutos próprios, a serem definidos em assembleia por seus socios fundadores. A entidade será responsável pela coordenação das atividades necessárias para se atingir os objetivos de colaboral, com a Administração da Estação Ecológica, de lodas as formas possiveis. Assim, poderão ser realizadas campanhas junto a pessoas fisicas e juridicas, orgáos públicos, instituiçōes de ensino e pesquisa, conseguindo por exemplo, a doação de máquinas e equipamentos, construção das obras, apoio especifico para o Programa de Educação Ambiental entre outros.

Esta Sociedade poderia tambem desenvolver açóes educativas de conscientização da comunidade local sobre a importância da Unidade de Conservação, atraves de palestras, distribuições de folhetos, publicaçóes nos meios de comunicação. Estas ações, desenvolvidas por voluntarios, poderiam enfocar, por exemplo, as medidas de prevenção a incêndios, cuidados na utilização de agrotóxicos, problemas decorrentes da caça furtiva e. principalmente destacar os grandes prejuizos ambientais decorrentes da utilizacao inadequada do solo. 


\section{Conclusões:}

A análise efetuada na Estaçâo Ecológica de lbicatu demonstrou que a urbanização crescente $e$ o desenvolvimento de atividades econômicas podem se traduzir numa contrapartida de pesados prejuizos ao ambiente natural. Assim, as múltiplas atividades do homem moderno têm levado em conta apenas os seus objetivos imediatos, justificados em geral pelo atendimento das necessidades socialmente determinadas, associadas ao regime de propriedade privada da terra.

Desta forma, os prejuizos ambientais relativos à qualidade da atmosfera, aos recursos hidricos, às condiçōes do solo, da vegetação, da vida animal, a harmonia da paisagem e, principalmente, as interrelações entre todos esses aspectos são bastante evidentes nos dias de hoje.

A atual situação ambiental verificada na Estação Ecologica de ibicatu confirma estas afirmações, a medida em que, através das anailises efetuadas neste trabalho, póde se constatar varias ameaças ao ecossistema local, representadas pelas ações equivocadas desenvolvidas nos seus arredores, somadas as dificuldades das autoridades responsáveis para administrar aquela Unidade de Conservação.

Assim, a legislação em vigor, que estabelece as normas disciplinares para o uso do solo no entorno de areas protegidas, em especial em Estaçōes Ecológicas está sendo desrespeitada. Verificou-se, constantemente, por exemplo, a presença de rebanhos de animais domésticos de propriedade particular, no interior da floresta, em total desacordo com a Alínea "a", parágrafo $1^{\circ}$, do Artigo $7^{\circ}$ da Lei 6.902 , de 24 de abril de 1981. Também nâo vem sendo observado o estabelecido na Resolução $n^{0} 13$, de 6 de dezembro de 1990, onde 
- Conselho Nacional do Meio Ambiente- CONAMA - resolve "que nas áreas circundantes das Unidades de Conservaçăo, num raio de dez quilometros, qualquer atividade que possa afetar a biota deverá ser obrigatoriamente licenciada pelo órgão ambiental competente e que este licenciamento só será concedido mediante autorização do órgão responsável pela administração da Unidade de Conservação".

Neste contexto, e fundamental e urgente a elaboração do Plano de Manejo da Estação Ecológica de lbicatu, como recomenda a legislação em vigor, a ser desenvolvido pela sua administraçäo. Ele e o instrumento indispensavel para manter a perfeita estabilidade daquele fragmento fiorestal, disciplinando as atividades ali deserivoividas e orientando a sua gestão.

O documento para 0 qual este trabalho se propóe a contribuir, deverá definir inicialmente a ocupação racional e organizada do solo da Estação Ecológica. Este processo, efetuado através do zoneamento adequado da área, estabelecerá os setores de uso distintos, em função das atividades ali desenvolvidas.

A proposta básica de organização espacial para aquela Unidade de Conservaçẫo, que pode servir como referência para o futuro, prevê o estabelecimento de cinco zonas: a Primitiva, a de Uso Extensivo, a de Uso Intensivo, a de Recuperação e a de Uso Especia!.

Estas zonas foram definidas em função da sua vocação especifica, das necessidades locais e das possibilidades de utilizaçăo da Estação Ecológica, discipinada peias leis vigentes. Esta legislação permite apenas o deserivolvimento na área de pesquisas cientificas controladas e de atividades voltadas para Educaçẫo Ambiental.

Em função dos objetivos a serem atingidos, propõe-se também a criação de cinco programas de manejo para a Estação Ecológica de Ibicatu, a saber: Desenvolvimento Fisico: Administração e Manejo: Educação Ambientai: Pesquisa e Mobilizaçăo Comunitaria. Interiigados, estes programas 
deveráo assegurar a efetiva proteção daquele ambiente natural e possibilitar a sua utilizaçăo adequada por parte da comunidade.

Cada um desses programas exigira a elaboração de projetos especificos, dimensionados para atender a demanda estimada. Eles deverão sei devidamente detalhados, de forma a fornecer informaçóes sobre os recursos humanos e materiais necessarios a sua execução.

Outra importante questão que precisa ser estudada e discutida no Plano de Manejo e a necessidade da ampliaçáo da area da Estação Ecologica de lbicatu. Com base nas observaçóes e análises efetuadas, pode-se inferir que devido as suas pequenas dimensóes, forma espaciá inadequada e condiçóes de isolamento geográfico, a estabilidade do fragmento florestal pode estar ameaçada. Portanto, torna-se necessária a realizaçáo de estudos aprofundados para determinar o grau de erosão genética ali existente e as eventuais medidas mitigadoras disponiveis para conter este terrivel processo de degradação ambiental.

Desde já, recomenda-se a criação de "zonas-tampão" no entorno da Estação Ecológica, onde o uso do solo deve ser parcialmente restrito para atividades que possam colocar em risco 0 ambiente local, como por exemplo o plantio da cana-de-açúcar, que vem atualmente ocorrendo em suas areas limitrofes. Os limites destas zonas poderão ser definidos pelos divisores das águas que compóem a microbacia hidrográfica local.

Outra pratica a ser adotada e a criação de corredores vegetados, interiigando os diversos fragmentos florestais existentes na região, de forma a propiciar a circulação e o escape de animais entre eles, assegurando assim o fluxo de material genético, fundamental para sobrevivencia das comunidades ali estabelecidas.

Acredita-se que a implementação do da Estação Ecológica de lbicatu será um fator decisivo para a efetiva conservacăo daquele fragmento fiorestal unico, extremamente importante para toda a regiäo, por abrigar os 
imponentes e milenares jequitibas. Eles são hoje testemunhas solitárias da devastacáo florestal, eietuada no territorio paulista em nome do progresso e poderăo se tornar o simbolo daquela Unidade de Conservação.

Qualquer intervenção na área exige, no entanto, a participaçâo do Instituto Florestal, orgâo da Secretaria de Estado do Melo Ambiente, responsável pela sua administração. Desta forma, cabe a sociedade como um todo e especialmente aos técnicos que atuam no setor ambiental, aos politicos e dirigentes se organizarem em torno da ideia de se trabalhar em pról da Estaçáo Ecologica de lbicatu, cobrando das autoridades encarregadas de sua administração mais empenho e dedicação nos trabalhos de conservação daquela Unidade. 


\section{REFERENCIAS SIBLIOCRÁFICAS:}

AB'SABER, AN A depressão periférica paulista: um setor das áreas de circundesnudação pós-cretáceas na bacia do Paraná. São Paulo, IGEOGIUSP, 1974, 99 p. (IGEOG, Series teses e monografias, 14).

AB'SABER, A. N. Diretrizes para uma política de preservação de reservas naturais no Estado de São Paulo. São Paulo, Instituto de Geografia/USP, 1977. ( Boletim Geografia e Planejamento, 30)

AGÉNCIA DE COOPERAÇÃO TÉCNICA DO JAPÃO. Construir a floresta, $1989.20 \mathrm{p}$.

AGUIAR, R. A. R. Direito do meio ambiente e participação popular. Brasilia, IBAMA, 1994.110p.

ALMEIDA, A.F. Avifauna de uma área defiorestada em Anhembi. Estado de São Paulo, Brasil. São Paulo, 1981.286 p. (Doutoramento - Instituto de BiocienciasiUSP).

ALMEIDA, A.F. Apontamentos das aulas de manejo de áreas silvestres. Piracicaba, ESALQ, 1983.35 p., pt. 1.

ALMEIDA, A.F., coord. Levantamento de campo na Estação Ecológica de lbicatu. Piracicaba, ESALQ/LCF, 1992.

ALMEIDA, A.F.; BENEDICT, M.; GUEDES, N.M.R. Plano de Manejo do Parque Estadual do Prosa. Campo Grande, Secretaria de Estado de Meio Ambiente, 1990.

ALMEIDA, A. F.; BITRAN, I.M.; BITTI, D.C.R.; ALVES, J.E.M.; PIMENTEL, D.M.C. Reserva particular do património natural do Morro da Vargem -. Ibiraçu, Centro Brasileiro de Estudos Ambientais; Aracruz Florestal; Universidade Federal do Espírito Santo; Mosteiro Zen Morro da Vargem, 1990.

ALMEIDA, A.F,; BITTID.C.R.; BITRAN, I.M.; ALVES, J.E.M. Projeto experimental de Educação Ambiental. Ibiraçu, Aracruz Celulose S/A.; ivosteiro Zen ivorro da Vargem; Comunidade Soto Zen-Shu, 1991. 
ALMEIDA, F.F.M. Fundamentos geológicos do relevo paulista. Săo Paulo, IGEOG/USP, 1974. (Série Teses e Monografias, 14).

AMARAL, W.A.N \& ROCHA, M.Z.P. Plano de ação voluntária em favor das Unidades de Conservação. In: CONGRESSO BRASILEIRO DE DEFESA DO MEIO AMBIENTE, 2., Rio de Janeiro, 1987. Anais. Rio de Janeiro, UFRJ, 1987. v.2.

BACHA, C. A distribuição geográfica das Unidades de Conservação existentes no Brasil. Piracicaba, ESALQ-USP, 1992.

BANNON, J. J. Leisure resources. New Jersey, Prentice Hall, 1976. 454 p.

BARBORAK, J.R.; MACFARLAND, C.; MORALES, R. Metodologia esquematica de planificacion operativa para areas silvestres individuales. Turrialba, Centro Agronomico Tropical de Investigación y Ensehanza, 1982.

BEGE, I. A. do R. \& MARTERER, B.T.P. Conservação da avifauna na região sul do Estado de Santa Catarina, Brasil. Fiorianópolis, FATMAIBAMA, $1991.54 \mathrm{p}$.

BERRIOS, M.B. R. Degradação ambiental na bacia do rio Piracicaba (SP). Såo Paulo, 1993. 186 p. (Doutoramento - Faculdade de Filosofia, Letras e Ciências Humanas/USP).

BERTONI, J.E. de A.; NEGREIROS, O.C.; CESAR, S.F.; NOFFS, M.S.; PFEIFER, R.M.; SERIO, F.C.; DOMINGUES, E.N.; SILVA, C.E.F.; DURIGAN, G.; MORAES, J.L., ANDRADE, W.J.; SILVA, D.A.; BARBOSA, A.F.; CENEVIVA, W.; MATTOS, I.F.A. Parque Estadual de Vassununga: Plano Conceitual de Manejo. Såo Paulo, Instituto Florestal, 1986.

BRASIL. Ministério do Interior. Secretaria Especial do Meio Ambiente. Programa de Estações Ecológicas. Brasilia, 1977. 42 p. (Série Meio Ambiente, 2).

BRASIL. Ministério do Interior. Secretaria Especial do Meio Ambiente. Encontro sobre áreas naturais preservadas na região neotropical. Brasilia, 1980.

BROKAW, N.V.L. Treefalls regrowth and community structure in tropical forest. London, Academic Press, 1985. p. 53-69. 
BUDOWSKI, G. Biological diversity and forestation in the tropics. In:

WIERSUN, K.T. ed. Strategies and designs for afforestation and tree planting. Wageningen, PUDOC, 1984. p. 115-27.

CANABRAVA, A.P. \& MENDES, M.T. A regiăo de Piracicaba. Revista do Arquivo Municipal, São Paulo, 14: 276-328, 1938.

CAPOBIANCO, J.P. Conservação de remanescentes florestais através da Educação Ambiental. In: CONGRESSO FLORESTAL BRASILEIRO, 6 , Campos do Jordão, 1990. Anais. São Paulo, Sociedade Brasileira de Silvicultura/Sociedade Brasileira de Engenheiros Florestais, 1990. p.200-4.

CAPULA, M. Simon \& Schuster's guide to reptiles and amphibians of the world. New York, Simon \& Schuster/Fireside, 1989. 256 p.

CARVALHO, H. M. Planejamento: noções gerais sobre o processo. São Carlos, E.E.S.C./USP, 1971.

CASTANHO FILHO, E.P. \& FEIJÓ, L.F.C. A política setorial de recursos naturais para o estado de São Paulo: contribuição à estratégia mundial para a conservação. Såo Paulo, Secretaria de Agricultura e Abastecimento de São Paulo, Coordenadoria de Pesquisa de Recursos Naturais, $1987.131 \mathrm{p}$.

CASTILLO, I. et al. Manual para la capacitación del personal de áreas protegidas. Washington, Departamento del Interior de los Estados Unidos de América/ Servicio de Parques Nacionales, s.d.

CAVALHEIRO, F. O planejamento de espaços livres: o caso de São Paulo. In: CONGRESSO NACIONAL SOBRE ESSÉNCIAS NATIVAS. SILVICULTURA EM SÃO PAULO. 2. Anais. São Paulo, Instituto Florestal, 1982. Revista do Instituto Florestal, São Paulo, 16-A (pt.3): 1819, 1982.

CHIARINI, J.V. \& DONZELLI, P.L. Levantamento por Fotointerpretação das classes de capacidades das terras do Estado de São Paulo.

Campinas, Instituto Agronómico, 1973.

CLEMENTS, F.E. Plant sucession: an analysis of the development of vegetation. Washington, Carnegie Institute of Washington, 1916. $124 \mathrm{p}$. 
COSTA, L.G. S. Estrutura e dinâmica de trecho de mata mesófila semidecidua, na Estação Ecológica de lbicatu, Piracicaba, SP. São Paulo, 1992, 187 p. (Mestrado - Instituto de Biociências/ USP).

CRESTANA, M.S.M.; TOLEDO FILHO, D.V.; CAMPOS, J.B. . Florestassistemas de recuperação com essências nativas. Campinas, CATI, 1993.

DARLIGTON, JR. P.J. Zoogeography, New York, John Wiley, 1957. 675 p.

DELPOUX, M. Ecossistema e paisagem. São Paulo, Instituto de Geografia/USP, 1974.23 p.

DENSLOW, J. S. Disturbance -mediated coexistence of species. In: PICKETT,S.T.A.; WHITE, P.S.,eds. The Ecology of natural disturbance and patch dynamics. Orlando, Academic Press, 1985. p.307-23.

DENSLOW, J. S. \& PADOCH, C. People of the tropical rain forest. Berkeley, University of California Press, 1988. $231 \mathrm{p}$.

DIEGUES, A.C.S. Populações tradicionais em Unidades de Conservação: o mito moderno da natureza intocada. São Paulo, Núcleo de Apoio à Pesquisa sobre Populaçōes Humanas e Áreas Úmidas Brasileiras; Centro de Culturas Maritimas, Pro-Reitoria de Pesquisa USP, 1993. (Serie: Documentos e Relatórios de Pesquisa, 1).

DORST, J. Antes que a natureza morra: por uma ecologia política. Săo Paulo, Ed. Blücher, 1973.

DUTRA, H. \& HERCULIANI, S. Treinamento para monitores do subprograma de interpretação da natureza do Parque Estadual da Cantareira. In: CONGRESSO FLORESTAL BRASILEIRO, 6., Campos do Jordão, 1990. Anais, Såo Paulo, Sociedade Brasileira de Silvicultura, Sociedade Brasileira de Engenheiros Florestais, 1990. p.193-196.

DUTRA, H.; GONÇALVES DA SILVA, A. P.; MENEZES, A.L.L.; FERNANDES, H.G.; MARQUES, R.; BARANA, S. Proposta de reformulaçấo do programa de Educaçăo Ambiental para as escolas que visitam o Parque Estadual da Cantareira - SP. Revista do Instituto Florestal, Såo Paulo, 4 (único): 1157-1159, março, 1992.

EMMONS, L.H. Neotropical rainforest mammals: a field guide. Chicago, Chicago University Press, 1991. 281 p. 
ENCALADA, M.A. Manual para el diseño de proyectos de Educación Ambiental. Quito, Fundación Natura, s/d. 33 p.

ESTADOS UNIDOS. FOREST SERVICE. DEPARTMENT OF AGRICULTURE. National forest landscape management. Washington, Government Printing Office, 1973. v.1.

EXPEDIÇÃO percorre $855 \mathrm{~km}$. de rios até Goiás. Folha de São Paulo, São Paulo, 27 de fev.1994. p. 10-5

EWUSIE, J. Y. Elements of tropical ecology. London, Heinemann Educational Books, 1980. 205 p.

FAO. Conservacion in situ de recursos fitogeneticos salvages revista de la situación y plan de accións (borrador). Roma, 1984.

FIRKOWSKI, C. O hábitat para a fauna. In: CONGRESSO FLORESTAL BRASILEIRO, 6., Campos do Jordão, 1990. Anais. São Paulo, Sociedade Brasileira de Silvicultura e Sociedade Brasileira de Engenheiros Florestais, 1990.

FRANKEL, O.H. \& SOULE, M.E. Conservation and evolution. Cambridge, Cambridge University Press, 1981. 327 p.

FRIEDMANN, J.R.P. A natureza do planejamento. In: Planejamento conceitos e natureza. Viçosa, Universidade Federal de Viçosa/Centro de Ensino de Extensão, 1971.

FRISCH, J.D. Aves brasileiras. São Paulo, Dalgas-Ecoltec. Ecol.Tecn. e Com. 1981.353 p. V.1

FUNCATE/DEPRN/FUNDAÇÃO FLORESTAL. Levantamento do programa olho verde, Săo Paulo, 1991.

FUNDAÇÃO BRASILEIRA PARA A CONSERVAÇÃO DA NATUREZA Conservação ambiental, uma missão nacional para a década dos setenta. Rio de Janeiro, FBCN/Fundação Getúlio Vargas, 1972.

FUNDAÇÃO BRASILEIRA PARA A CONSERVAÇÃO DA NATUREZA. Conceito de conservação, Belém, SUDAM, 1976. 11 p.

FUNDAÇÃO ESTADUAL DE ENGENHARIA DO MEIO AMBIENTE -FEEMA Vocabulário básico de meio ambiente. Rio de Janeiro,1990. 
FUNDAÇÃO SISTEMA ESTADUAL DE ANÁLISE DE DADOS - SEADE. Anuário Estatístico do Estado de São Paulo-1991, São Paulo, 1992.

FUNDAÇÃO SISTEMA ESTADUAL DE ANÁLISE DE DADOS - SEADE. Perfil Municipal - 1980-91. Região Administrativa de Campinas. São Paulo, 1993. v. 4.

FUNDACÃO SOS MATATA ATLÂNTICA \& INSTITUTO NACIONAL DE PESQUISAS ESPACIAIS. Atlas da evolução dos remanescentes fiorestais e ecossistemas associados do domínio da Mata Atlântica no Estado de São Paulo no período de 1985-1990. São Paulo, 1992.

FUNDO DE DESENVOLVIMENTO FLORESTAL. Florestar Estatistico, São Paulo, (1): 10, mar 1993a.

FUNDO DE DESENVOLVIMENTO FLORESTAL Florestar Estatístico. São Paulo, 1 (2): 29, jun.out. 1993b.

GOLDENSTEIN, L. Subsidios para um planejamento sistematizador de proteção das paisagens do Estado de São Paulo. Revista do Instituto Fiorestal, São Paulo, 16 (pt. 3): 1530-33, 1982.

GOUVÊA, Y. M.G. Áreas de proteção ambiental e demais Unidades de Conservação. In: CONGRESSO BRASILEIRO DE ENGENHARIA SANITÁRIA E AMBIENTAL,13., Maceió, 1985. Anais. Maceió, Cetesb/ABES, 1985. v.10.

GRÖNING, G. \& NOHL, W. Freiraumplanung - Versuch einer Orientierung. Stadtbauwelt, 63 (34): 108-109, 1972.

GUEDES, Joaquim Plano diretor de desenvolvimento integrado Piracicaba, s.c.p., 1974.

GUILLAUMON, J. R. Planejamento do uso do solo frente à necessidade de proteção dos ecossistemas naturais. In: CONGRESSO NACIONAL SOBRE ESSÊNCIAS NATIVAS. SILVICULTURA EM SÃO PAULO, 2., Campos do Jordão, 1982. Anais. Såo Paulo, Instituto Florestal, Revista do Instituto Florestal, São Paulo, 16A. (pt. 3):1874-1895. 1982.

GUILLAUMON, J.R. Usos múltiplos: lazer. São Paulo, Instituto Florestal, 1986. $43 \mathrm{p}$.

GUiMiRE, K. Parks and people; livehood issues in National Parks management in Thailand and Madagascar. Genebra, UNRISD, 1991. 
HILTHY, S.L. \& BROWN, W.L. A guide to the birds of Colombia. Princeton, Princeton University Press, $1986.836 \mathrm{p}$.

IEACATI, s.n.t.

INSTITUTO BRASILEIRO DE MEIO AMBIENTE E DOS RECURSOS RENOVÁVEIS (IBAMA) IFUNATURA Sistema nacional de Unidades de Conservação: aspectos conceituais e legais. Brasilia, 1989.

INSTITUTO BRASILEIRO DE DESENVOLVIMENTO FLORESTAL Diagnóstico do sistema de conservação e preservação de recursos naturais. (Subsistema de planejamento florestal) Brasilia, $1978.138 \mathrm{p}$.

INSTITUTO BRASILEIRO DE DESENVOLVIMENTO FLORESTAL. Fundaçăo Brasileira para a Consenvação da Natureza. Reserva Biológica de Poço das Antas. Brasilia, 1981a.

INSTITUTO BRASILEIRO DE DESENVOLVIMENTO FLORESTAL. Fundação Brasileira para a Conservação da Natureza. Parque Nacional do Iguaçu. Brasilia, 1981b.

INSTITUTO BRASILEIRO DE DESENVOLVIMENTO FLORESTAL. Fundação Brasileira para a Conservação da Natureza. Parque Nacional do Araguaia. Brasilia, 1981 c.

INSTITUTO BRASILEIRO DE DESENVOLVIMENTO FLORESTAL.Fundação Brasileira para a Conservação da Natureza. Reserva Biológica de Sooretama. Brasilia, 1981d.

INSTITUTO BRASILEIRO DE DESENVOLVIMENTO FLORESTAL. Fundação Brasileira para a Conservação da Natureza. Parque Nacional da Serra da Canastra. Brasília, 1981 e.

INSTITUTO BRASILEIRO DE DESENVOLVIMENTO FLORESTAL. Fundação Brasileira para a Conservação da Natureza. Parque Nacional de Caparaó. Brasilia, $1981 f$.

INSTITUTO BRASILEIRO DE DESENVOLVIMENTO FLORESTAL. Fundação Brasileira para a Conservação da Natureza. Parque Nacional da Tijuca. Brasilia, 1981g.

INSTITUTO BRASILEIRO DE DESENVOLVIMENTO FLORESTAL. Fundação Brasileira para a Conservaçáo da Natureza. Parque Nacional de Ubajara. Brasilia, 1981h. 
INSTITUTO BRASILEIRO DE GEOGRAFIA E ESTATISTTICA. Coleção de monografias. Rio de Janeiro, 1955 v. 36.

INSTITUTO BRASILEIRO DE GEOGRAFIA E ESTATISTTICA. Recursos naturais, meio ambiente e poluição. Rio de Janeiro, 1977 . v. $1 / 2$.

INSTITUTO BRASILEIRO DE GEOGRAFIA E ESTATISTTICA. Manual técnico da vegetação brasileira. Rio de Janeiro, 1992. (Manuais Técnicos em Geociências, 1).

INSTITUTO DE BOTÂNICA. Desenvolvimento e implantação de modelos alternativos de recomposição vegetal com espécies nativas na Fazenda São Carlos - Santa Cruz das Paimeiras-SP. São Paulo, Secretaria do Meio Ambiente, 1993.

INSTITUTO FLORESTAL Dependências do Instituto Florestal do Estado de São Paulo. São Paulo, Secretaria do Meio Ambiente, 1993.

INTERNATIONAL UNION FOR CONSERVATION OF NATURE AND NATURAL RESOURCES. United nations list of National Parks and protected areas. Cambridge, IUCN, 1985.

INSTITUTO DE PESQUISAS TECNOLÓGICAS. Mapa geológico do Estado de São Paulo. São Paulo, 1981. (Escala 1: 500.000 - v. I),

KAGEYAMA, P. Y. Estudo para implantações de matas ciliares de proteção na bacia hidrográfica do Passa Cinco, visando a utilização para abastecimento público. Piracicaba, FEALQ,1986.

KAGEYAMA, P. Y. Conservação "in situ" de recursos genéticos de plantas. Piracicaba, IPEF (35): 7, abr.1987.

KAGEYAMA, P. Y. Sucessão secundária, estrutura genética e plantações de espécies arbóreas nativas. Piracicaba, IPEF (41/42), 83-93, 1989.

LIMA, W.P. Função hidrológica da mata ciliar. In: SIMPÓSIO SOBRE MATA CILIAR. Anais. Campinas, Fundação Cargill, 1989.

LITTON, Jr. R. B.; Forest landscape description and inventories - a basis for land planning and design. Berkeley, USDA /Forest Service, Pacific Southwest Forest and Range Experiment Station, 1968.

LONGMAN, K \& JENIK, J. Tropical forest an its environment, London, Longman, 1974. $196 \mathrm{p}$. 
LOVEJOY, T. E.; BIERREGAARD, R.O.; RANKIN, J.; SCHUBART,O.R. Ecological dynamics of tropical forest fragments. In : SUTTON, S.L.; WHITMORE, T.C.; CHADWICK, A.C., eds. Tropical rain forest: ecology and management. Oxford, Blackwell, 1983. p. 377-384.

LUNA, Hugo C. La conservación de la naturaleza: Parques Nacionales argentinos. 3 ed. Buenos Aires, Servicio Nacional de Parques Nacionales, 1977.

LUNDEEN, L.J. \& DEVILBISS, J. M. Problem definition: the initial requirement for land management planning. Lexington, University of Kentucky, 1979.

MACFARLAND, C. Esquema de la metodologia para la preparación de planos de interpretación y Educación Ambiental de áreas silvestres. Turrialba, Centro Agronómico Tropical de Investigación y Ensekianza, 1982.

MACKINNON J., CHILD, K.; THORSELL, J. Managing protected areas in the tropics. Cambridge, IUCN, 1986.

MARCONDES, M.A.P.; ANDRADE, W.J. Terminologia em manejo de áreas silvestres. In: CONGRESSO FLORESTAL BRASILEIRO, 6. Campos do Jordão, 1990. Anais, São Paulo, Sociedade Brasileira de

Silvicultura/Sociedade Brasileira de Engenheiros Florestais, 1990, p.778782.

MARINHO FILHO, S. \& REIS, M.L. A fauna de mamíferos associada às matas de galeria. In: SIMPÓSIO SOBRE MATA CILIAR. Anais. Campinas, Fund. Cargill, 1989.

MILANO, M. S. Parques e reservas: uma análise da politica brasileira de Unidades de Conservação. Revista Floresta, Curitiba, 16: (1/2): 4-9, Curitiba, jun/dez., 1985.

MILANO, M.S. Sistema nacional de Unidade de Conservação do Brasil: realidade técnico-politica. In: CONGRESSO FLORESTAL BRASILEIRO, 6., Campos do Jordăo, 1990. Anais. São Paulo, Sociedade Brasileira de Silvicultura e Sociedade Brasileira de Engenheiros Florestais, 1990.

MILLER, K.R. La significación de areas silvestres, definiones, nomenclaturas; los objetivos y plan del seminario. Missiones, instituto Interamericano de Ciencias Agricolas de la OEA, 1969. 
MOORE, A. La capacitacion: un desafio para el futuro de las areas silvestres protegidas. Flora, Fauna y Áreas Silvestres, Santiago, 2 (5):6-7, sept/dic, 1987.

MOORE, A.\& ORMAZABAL, C. Manual de planificacion de sistemas nacionales de areas silvestres protegidas em America Latina. Santiago, Oficina Regional de la FAO para America Latina y el Caribe, 1988.

MORELLATO, L.P.C. Levantamento fiorístico das arvores da Fioresta da Serra do Japi. In: História natural da serra do Japi, ecologia e preservação dée umá área florestal no sudeste do Brasil. Campinas, Unicamp; São Paulo, FAPESP, 1992

MORELLATO, L.P.C., RODRIGUES, R.R., LEITÃO FILHO, H.F.; JOLY, C.A. Estudo comparativo de fenologia de espécies arbóreas de florestas de altitude e mesófila decidua na serra do Japi, Jundial, São Paulo. Revista Brasileira de Botânica, São Paulo, 12: 85-9, 1989.

NAROSKY, T. \& YZURIETA, D. Guia para la identificación de las aves de Argentina y Uruguay. Buenos Aires, Associación Ornitologica del Plata, $1987.345 \mathrm{p}$.

OGAWA, H.Y; MATTOSO, A.Q, CUSTÓDIO FILHO, A.; SÉRIO, F.C. Áreas silvestres, manejo, conservação da biodiversidade da Mata Atlântica. In: CONGRESSO FLORESTAL BRASILEIRO, 6. Campos do Jordão, 1990. Anais. São Paulo, Sociedade Brasileira de Silvicultura e Sociedade Brasileira de Engenheiros Florestais, 1990.

OMETTO, J.C. Registros e estimativas de parâmetros meteorológicos da região de Piracicaba, SP. Piracicaba, FEALQ, 1991.

PAVÃO, T Abatijé Cumandaí - tupi-guarani-português e vice-versa. São Paulo, Nagycolor, 1987.

PELLEGRINO, P.R.M. Por um design ambiental - espaço de aplicação: a região de Sorocaba. São Paulo, Faculdade de Arquitetura e Urbanismo/USP, 1986.

PENNA, P.C. de O. Planejamento: conceito. In: Planejamento conceitos e natureza. Viçosa, Universidade Federal de Viçosa, 1971. 
PINTO, H.S. Clima da Serra do Japi. In: MORELLATO, L.P.C. org. História natural da serra do Japi: ecologia e preservação de uma área florestal no sudeste do Brasil. Campinas, Unicamp, 1992.

PIRACICABA. Prefeitura Municipal. Centro Municipal de Planejamento. Plano diretor de desenvolvimento, 1985. v.1.

PIRACICABA. Prefeitura Municipal. Piracicaba - passado e presente. São Paulo, Secretaria de Ciência e Tecnologia, 1988.

PIRACICABA. Prefeitura Municipal. Secretaria Municipal de Planejamento. Perfil sócio-económico do município de Piracicaba. 1992. 33 p. (Relatório interno)

PLATTS. W.S et al. Methods for evaluating riparian hábitats with applications to management. Forest Service General Technical. 1987. 177 p. (Report INT, 221)

PORTO, M. L.; LONGHI, H.M. CITADINI, V. RAMOS, R.F.,MARTIATH, J.E.de A. Levantamento fitossociológico em áreas de uma mata de baixo na Estação Experimental de Silvicultura. Acta Amazônica, Manaus, $\underline{6}(3)$ : $301-18,1976$.

PRESTON, F. W. The canonical distributions of commonness and rarity: part 2. Ecology, Durham, 41 (4):611-27, 1960.

QUINTÃO, A. Evolução do conceito de Parques Nacionais e sua relação com o processo de desenvolvimento. Brasil Florestal, (54): 13-28. Brasilia, abr.jun. 1983.

RANKIN-DE-MERONA, J.M; ACKERLEY,D.D. Estudos populacionais de árvores em florestas fragmentadas e as implicações para conservação "in situ" das mesmas na floresta tropical da Amazónia. Revista Instituto Pesquisas Florestais, Piracicaba (35): 47-59, 1987.

RANZAN!, G. Subsidios à geografia de Piracicaba. Piracicaba, Instituto Histórico e Geografico de Piracicaba, 1966.

RANZANI, G.: FREIRE, O, KINJO, T. Carta de soios do município de Piracicaba. Piracicaba, Centro de Estudos de Solos, 1966. $85 \mathrm{p}$.

RIZZINI, C.T. Tratado de fitogeografia do Brasil. São Paulo, HUCIEC/EDUSP, 1979. $374 \mathrm{p}$. 
RODRIGUES, R.R. Análise estrutural das formações florestais ripárias. In: SIMPÓSIO SOBRE MATA CILIAR. Anais. Campinas, Fundaçăo Cargill, 1989.

RODRIGUES, R.R., LEITÃO FILHO, H. de F., CRESTANA, M. de S.M. Recomposição artificial da mata ciliar ao redor da represa de abastecimento de água do município de Iracemápolis, SP. Iracemápolis, Prefeitura Municipal de Iracemápolis/Campinas, CATI, 1987.

SALTINHO comemora segundo aniversário. Jornal de Piracicaba, Piracicaba, 9 de maio 1994. p.1.

SANTOS, E. Anfibios e répteis do Brasil (vida e costumes). Belo Horizonte, Itatiaia, $1981.263 \mathrm{p}$.

SANTOS, J. A.O; MACEDO, L.A.A.; ANDRÉA, M.M.; BORN, R.H. Planejamento ambiental - Instrumento de controle da qualidade do meio ambiente. In: CONGRESSO BRASILEIRO DE ENGENHARIA SANITÁRIA E AMBIENTAL, 13., Maceí, 1975. Anais. São Paulo, USP/Faculdade de Saúde Pública, 1975.

SÃO PAULO (Estado). Secretaria da Agricultura. Coordenadoria da Pesquisa de Recursos Naturais. Instituto Florestal Plano de Manejo para o Parque Estadual da liha do Cardoso. São Paulo, 1974. (Boletim Técnico, 9).

SÃO PAULO (Estado). Secretaria de Economia e Planejamento. São Paulo em exame: região de governo de Piracicaba, São Paulo, 1990.

SÃO PAULO (Estado). Secretaria de Estado do Meio Ambiente. Coordenadoria de Educação Ambiental. Educação Ambiental em Unidades de Conservação e de produção. São Paulo, 1991. 104 p. (Série Guias).

SÃO PAULO (Estado). Secretaria de Estado do Meio Ambiente. Política municipal de meio ambiente; orientação para os municípios. 2. ed. São Paulo, 1992.

SÃO PAULO (Estado). Secretaria do Meio Ambiente. Coordenação de Proteção de Recursos Naturais. Instituto Florestal. Plano de Manejo do Parque Estadual da Ilha Anchieta. Sáo Paulo, 1989. (Série Registros, 1). 
SCHAUENSEE, R.M de \& POULE, E.L.. Guide to the birds of South America. Edinburgh, Oliver and Boyd, $1970.470 \mathrm{p}$.

SCHAUENSEE, DE R.M. \& PHELPS JR, W. A guide to the birds of Venezuela. Princeton, Princeton University Press, 1978. $424 \mathrm{p}$.

SEIBERT, $P$. Seminário - manejo da paisagem e mapeamento da vegetação - Parque Estadual de Campos do Jordão. Secretaria de Estado dos Negócios da Agricultura, 1974. (Publicação IF,5).

SEIBERT, P; NEGREIROS, O.C.; BUENO, R.A.; EMMERICH, W.; MOURA NETTO, B.V.; MARCONDES, M.A.P.; CESAR, S.F.; GUILLAUMON, J.R.; MONTAGNA, R.G.; BARRETO,R.A.A.; NOGUEIRA, J.C.B; GARRIDO, M.A.O.; MELLO FILHO, L.E.; EMMERICH, M. ; MATTOS, J.R.; OLIVEIRA, M.C.; GODOI, A. Plano de Manejo do Parque Estadual de Campos do Jordão. São Paulo, Secretaria de Estado dos Negócios da Agricultura, 1975. (Boletim Tecnico, 19)

SERRA FILHO, R. et al. Levantamento da cobertura vegetal natural e o reflorestamento no Estado de São Paulo. Boletim Técnico do Instituto Fiorestal, São Paulo, 11 (1): 1-53, 1974.

SHUGART, H.H. A theory of forest dynamics. New York, Springen, 1962.

SICK, H. Ornitologia brasileira, uma introdução. Brasilia, Ed. Universidade de Brasilia, 1985.827 p.

SILVA, L. L. da. Ecologia: manejo de áreas silvestres. Santa Maria/UFSM, CEPET/FATEC, 1992a.

SILVA, W.L. As aves da Serra do Japi. In: MORELLATO, L.C.P. (org.). História natural da Serra do Japi: ecologia e preservação de uma área florestal do sudeste do Brasil. Campinas, Ed. UNICAMP, 1992b.

SILVA, W.S \& FORNASARI FILHO, N. Unidades de Conservação ambienta! e áreas correlatas no Estado de São Paulo. 2.ed. São Paulo, IPT, 1992.

SORRENTINO, M: BARSELERI, R.C.D.; IMAMOMOTO, M.: PEREIRA DE MELO, A.L.; Educação Ambiental extensão universitária: uma experiencia em escola pública de primeiro Grau. In : CONGRESSO FLORESTAL BRASILEIRO, 6., Campos do Jordão, 1990. Anais. São Paulo, Sociedade Brasileira de Silvicultura e Sociedade Brasileira de Engenheiros Florestais, 1990. 
SPAROVEK, G., VAN LIER, Q.J., LEPSCH, IF. Gmap: um programa de manipulação de mapas temáticos adaptado a computadores de pequeno porte. $O$ exemplo do municipio de Piracicaba. Boletim Informativo da Sociedade Brasileira de Ciencia do Solo, Campinas, 18 (1): 15-19,jan/dez.1993.

STEINBLUMS, I.J.; FRÓEHLICH, H.A.; LYONS, J.K. Designing stable buffer strips for stream protection. Journal of Forestry, Bethesha 82 (1): 49 52 , jan.1984.

THELEN, K.D.\& DALFELT, A. Política para el manejo de areas silvestres. San José, Editorial Universidad Estatal da Distancia. 1979. 107 p. (Serie Educacion Ambiental, 1).

TORRES, M. C.T.M. Aspectos da evolução da propriedade rural em Piracicaba - no tempo do Império. Piracicaba, Academia Piracicabana de Letras, 1975. 212 p.

VIANA, V. M. Biologia e manejo de fragmentos de florestas naturais. In: CONGRESSO FLORESTAL BRASILEIRO, 6. Campos do Jordăo, 1990. Anais. São Paulo, Sociedade Brasileira de Silvicultura e Sociedade Brasileira de Engenheiros Florestais, 1990. p 113-18.

VICTOR, M.A.M.A A devastação fiorestal. São Paulo, Sociedade Brasileira de Silvicultura, $1975.48 \mathrm{p}$.

WHITMORE,T.C. Gaps in the forest canopy. In:TOMLINSON \& P.B. ZIMMERMAN, M.H. Tropical trees as a living systems. Cambridge, Cambridge University Press, 1977. cap. 27, p.639-55.

WILCOVE, D.S.; MCLELLAN, C.H.; DOBSON, A.P. Hábitat fragmentation in the temperate zone. In SOULE, S. ed. Conservation biology: the science of scarcity and diversity, Sunderland, Sinauer Associates, 1986. p. 237-56.

WLLLS, E.O. The composition of avian communities in remanescent woodlots in Southern Brazil Papéis Avulsos de Zoologia, Sâo Paulo, 31 (1): $1-25,1979$.

WOMBLE, J.R. Land use planning: a private sector viewpoint. Lexington, Ed. University of Kentucky/College of Agriculture, 1979. 